\title{
DWR- 1650
}

\section{MUSTER}

ORNR. .4579

UC-48-Biology and Medicine

DOSE-ESTIMATION STUGIES RELATEL TO

PROPOSED CONSTRUCTION OF AN

ATLANTIC-PACIFIC INTEROCEANIC CANAL

WITH NUCLEAR EXPIOSIVES: PHASE III

Steplien V. Kaye

Poul S, Rohwer

OAK RIDGE MATzoNAL LaboRATORY

operoted by

UNION CARBIDE CORPORATION

tor the

U. 5. ATOMIC ENERET COMBAISSION 


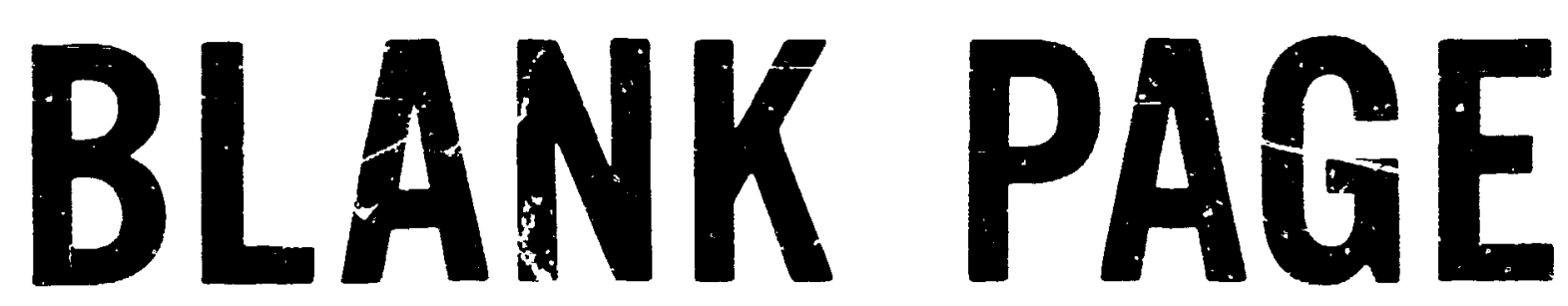




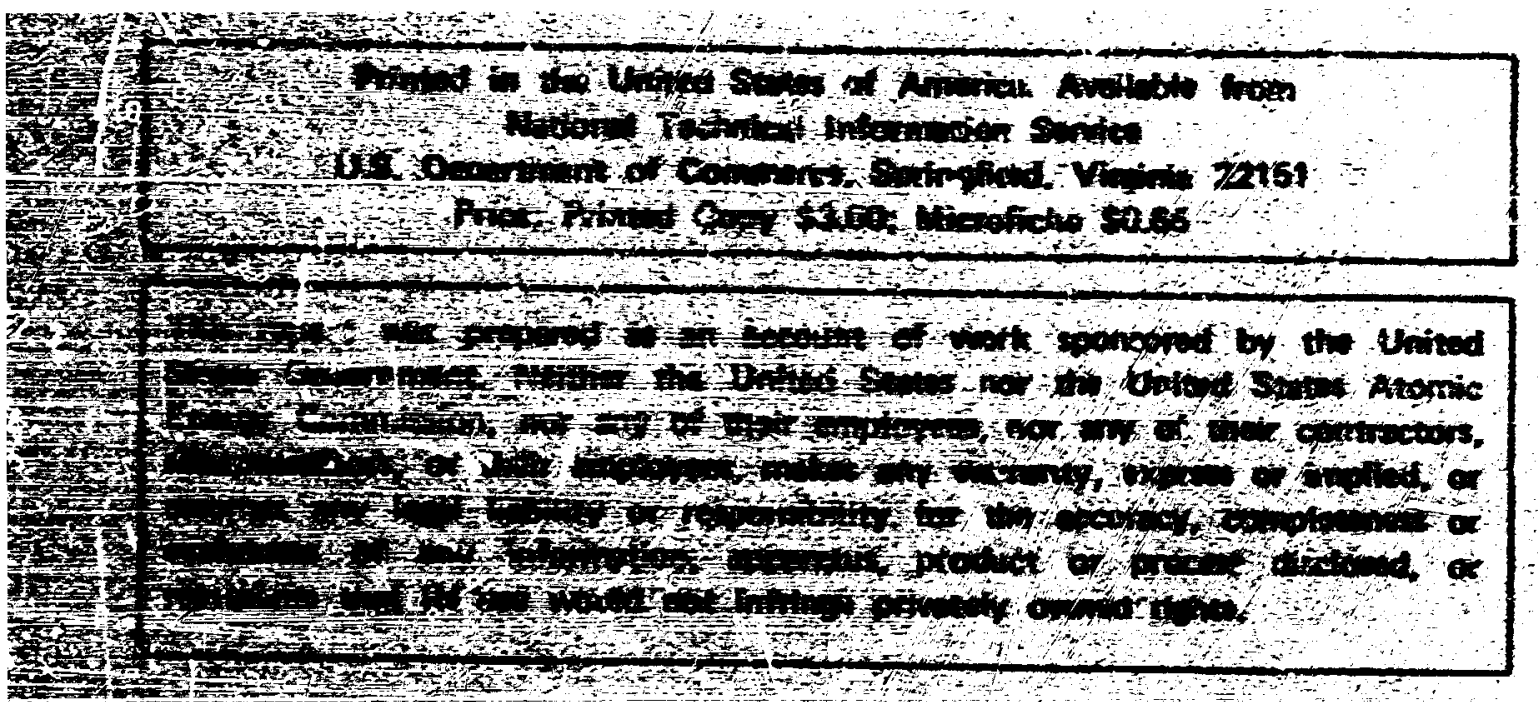

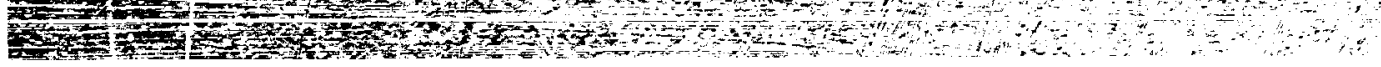


BLANK PAGE 
iuri,ract No. H-1405-eng-26

הEALTH PHYSICS DIVISION

DOSE-ESTMMATIO: STUDIES RELATED TO PROPOSED CONSTRUCTION

CF AN AYANTIC-PACIFIC INTEROCEANIC, C.:NAL

WT:E NJCLEAR EXPLOSTES: PHASE II:

Stephen V. Kaye

and

Paul S. Rohwer

LEGAL NOTICE

This report wrs prepared is an account of work This report waited States Government. Neither sponsored United States nor the United States Atomic Energy Comminion, nor any of their employees, nor any of their contractors, subcontractors, or their employeas, their cantuactors, expres or implied, or assumes any

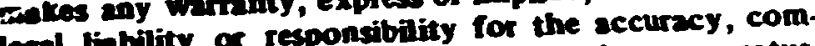
loga bisthy or respons of any information, apparatus, pleteness or userulnes of any informationts that its use

product or proces divelosed, or represents

DECEMBER 1970

OAK RIDGE NATIONAL IABORATORY

Oak Kidge, Tennesjee

Operated iy

UNION CARBIDE CORPORATION

For the

U.S. ATOMIC ENERGY COMMISSION 


\section{ACKNOWLEDGMENTS}

ithe authors wish to thank E. G. Struxness for many valuable contributions to the study and to this final report. Our appreciation is also extended to K. E. Cowser and W. S. Snyder for technical advice rendered throughout the course of the study, and to W. D. Turner of the Computing Technology Center for programing assistance. Thanks are extended tc Mary P. Stooksbury and Joanne S. Sanford for typing the final draft of this report. The cooperation enjoyed with Battelle Memorial Institui,e, Columbus Laboratories (W. E. Martin, S. G. Bloom, ard A. A. Levin) and AEC Nevada Operations Office (A. W. Klement, Jr. and R. L. Gotchy) is appreciated.

This report was prepared for Battelle Memorial Institute, Columbus Laboratories, under U. S. Atomic Energy Commission, Nevada Operations Office, Coniract AT (26-1)-171. 
CONTENTS

Page

Ackruwledgments.................................. ii

Abstract....................................... 1

1.0 Introduction................................ 3

1.1 Isthmian Canal Plans........................ 3

1.2 Nuclear Excavation Concept.................... 3

1.3 IOCSC Investigations...................... 4

1.4 BCL Bioenvironmental Feasibility Study............ 4

1.5 ORNL Dose Estimation Study................ 5

References for Chapter $1.0 . \ldots \ldots \ldots \ldots \ldots \ldots \ldots \ldots \ldots . \ldots . \ldots 8$

2.0 Information Used for Estimating Dose................ I0

2.1 Nuclear Explosives and Radionuclide Production....... 10

2.1.1 Source Term for Estimating External Dose...... 10

2.1.2 Source Term for Estimating Internal Dose....... 11

2.1.3 Detonation Programs Assumed for Routes 17

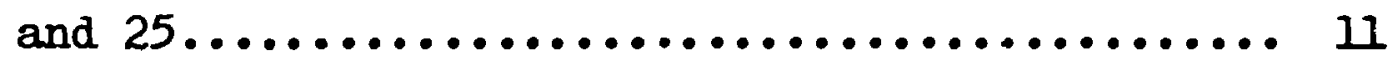

2.2 Locations for Computing Dose.................... 14

2.2.1 External Dose (Route 17)..................... 14

2.2.2 Jnternal Dose (Routes 17 and 25).......... 16

2.3 Modes of Exposure......................... 18

2.3.1 External Modes of Exposure (Route 17)........ 18

2.3.2 Internal Modes of Exposure (Routes 17

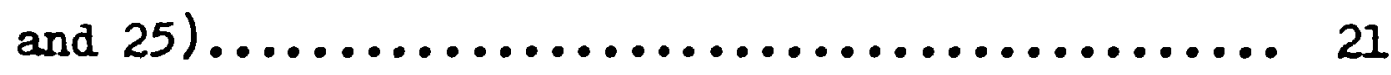

2.4 Population Data for Estimating Genetically

Significant Dose for Route $17 . \ldots \ldots \ldots \ldots \ldots \ldots \ldots \ldots \ldots 21$ 
CONTENTS, continued

Page

2.5 Age-Dependent Parameters for Internal Dose...... 22

2.5.i Organ Mass...................... 25

2.5.2 Effective Absorbed Erergy $\ldots \ldots \ldots \ldots \ldots 25$

2.5.3 Fraction of Intake Reaching Organ of Reference...................... 28

2.5.4 Effective Half-Time............... 33

2.5.5 Daily Radionuclide Intake........... j;

2.6 Assumptions for Computing External Beta Dose

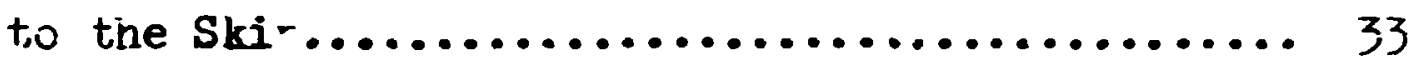

2.7 Special Radiological Protection Considerations... 36

2.7.1 Simultaneous Internal Exposire of Multiple Organs.................. 36

2.7.2 Additivity of Intemal and External Dose.. 37

2.7.3 Apportionment of Genetic Dose to Canal

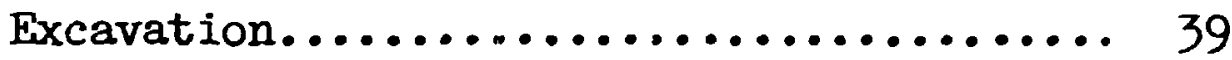

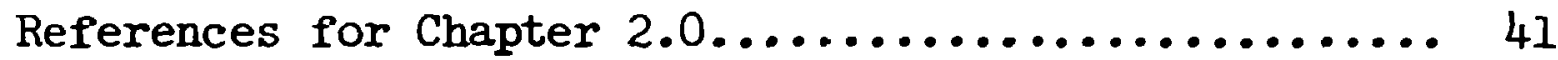

3.0 Dose Estimation Models...................... 44

3.1 External Exposure to a Cortaminated Landscape.... 44

3.1.1 Dose Rate...................... 45

3.1.2 Cumulative Dose.................. 50

3.2 Internal Exposure from Ingestion of Food and Drink.......................... 50

3.2.1 All Organs Except the G.I. Tract....... 51

3.2.2 G.I. Tract...................... 52

3.3 Genetically Significant Dose.............. 54

References for Chapter $3.0 \ldots \ldots \ldots \ldots \ldots \ldots \ldots \ldots \ldots$ 
4.0 Radiation Dose Estimates.................... 57

4.1 Potential Exposures for Roste 17............ 5?

4.1.1 External Gama Dose from Contaminated

Land Surface.......

4.1.2 Externai Beta Dose to Skin........... 60

4.1.3 Inter:al Dose fran Ingestion.......... 60

4.1.i Sumation of External ard Irternal Dose

Estimates........................ 6it

4.2 Potential Exposires for Route 25............. 69

4.2.1 Irterral Dose from Irgestion.......... 59

4.2.2 Summation of External ard Internal Dose

Estimates........................69 69

4.3 Limitations of these Dose Estimates........... 73

4.3.I Exterral Dose...................... 75

4.3 .2 Internal Dose................... 80

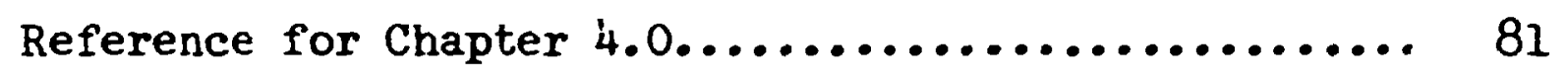

5.0 Comparison of Dose Estimates with Rauization Safety

Criteria................................ 82

5.1 Assessment of the Potential Doses Estimated for

Various Times of Reeritry to Watershed 5, Route

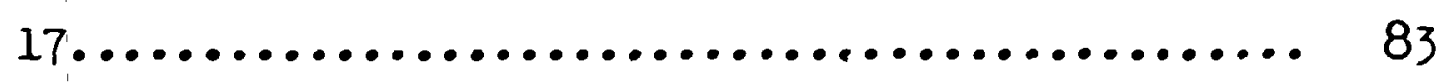

5.1.1 Maximum Annual Doses................ 8!

5.1.2 Genetically Significart Doses.......... 86 
CONTENTS, continued

Page

5.2 Assessment of the Poteritial Doses Estimated for Various Times of Reeritry to Watershed 2, Rodte

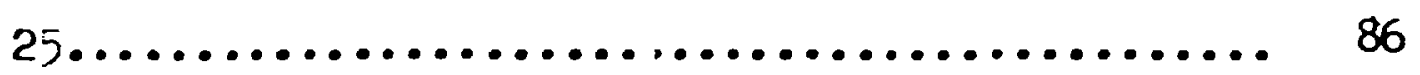

¡.2.1 Maximim Annual Doses............... 88

5.2.2 Geneically Significant Doses.......... 88

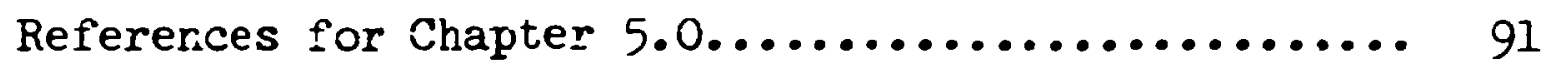

6.0 Conclusions ard Recorrsin: 29 tions................. 92

6.I Oecupational Workers.................... 92

6.2 Populations Outside the Exclusion Area......... 93

6.3 Reertry of General Popilation to Exclusion

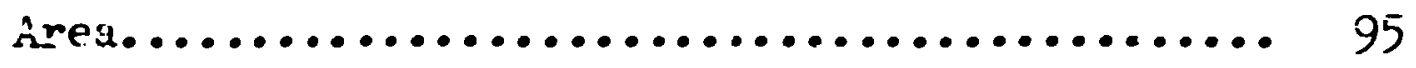

6.4 Fadiological Safety-Feasibility of a Sea-LeveI Canal Excavated with Nuclear Explosives........ 97

6.5 Further Research Required to Improve the Estimates of Potential Dose............... 98

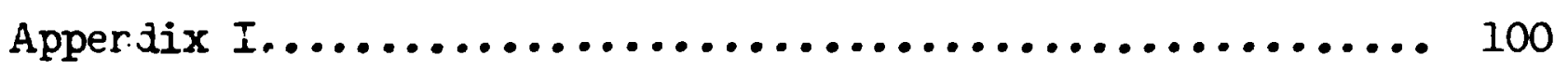

Appendix II............................... 104

Apperdix III............................. 111

$\therefore$-penaix IV............................... 118

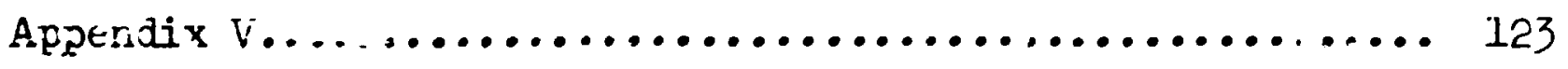

Appendix

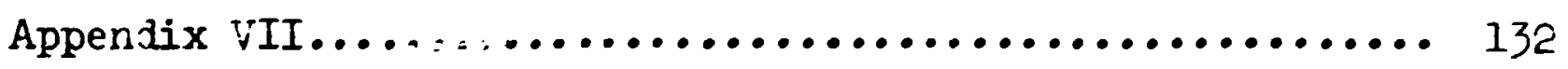




\section{LIST OF TABLLS}

$\underline{\text { Page }}$

2.1 Radionuclide Lists for Internal Dose............... 12

2.2 Detonation Programs Assumed for Routes 17 and 25........ 13

2.3 Correction Factors Compiled by BCL for Estimating

Potentiai Radiation Doses in Different Watersheds

in the Vicinity of Routes 17 and $25 \ldots \ldots \ldots \ldots \ldots \ldots . \ldots 19$

2.4 Age Distributions and Birth Rates for Populations

Indigenous to Route $17 \ldots \ldots \ldots \ldots \ldots \ldots \ldots \ldots \ldots \ldots \ldots . \ldots \ldots$

2.5 Variations in Organ Mass as a Function of Age........... 26

2.6 Variations in Effective Absorbed Energy as a

Function of Age............................. 29

2.7 variations in the Fraction of Ingested ${ }^{89} \mathrm{Sr}$ and ${ }^{13 I_{I}}$

Reaching the Reference Organs as a Function of Age....... 34

4.1 Partition of Potential External Gamms Dose Between

0-3 Years and 3-70 Years after First Detonation.......... 58

4.2 Summation of Dose Estimates for Modes of Exposure

Considered, Watershed 5, Route 17. Exposure starting

2.652 years after first detonation (30 days after

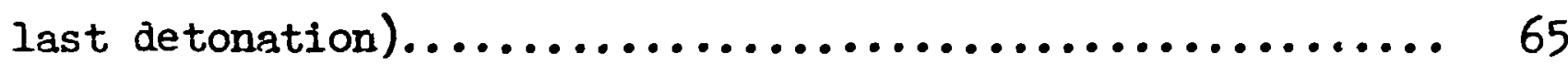

4.3 Summation of Dose Estimates for Modes of Exposure

Corsidered, Watershed 5, Route 17. Exposure stariing

5 years after first detonation......................66

4.4 Sumation of Dosc Estimates for Modes of Exposure

Considered, Watershed 5, Route 17. Exposure starting

30 years after first detonation.................... 
vi11

IIST OF TABLES, continued

Page

4.5 Summation of Dose Estimates for Modes of Exposure Considered, Natershed 2, Route 25. Exposure starting

1.570 years after first detonation (30 days after last detonation). 70

4.6 Summation of Dose Estimates for Modes of Exposure Considered, Watershed 2, Route 25. Exposure starting

5 years after flrst detonation.................. 71

4.7 Summation of Dose Estimates for Modes of Exposure Considered, Watershed 2, Route 25. Exposure starting 30 years after first detonaticn................. 72

5.1 Assessments of Estimated Average Annual Doses to Critical Population Groups for Various Assumed Times

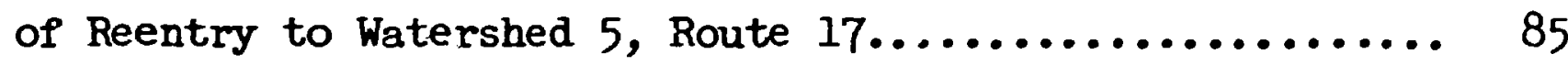

5.2 Assessments of Estimated Genetically Significant Doses to Critical Popuiation Groups for Various Assumed Times of Reentry to Watershed 5 , Route $17 \ldots \ldots . . . \ldots \ldots$

5.3 Assessments of Estimated Average Annual Doses to Critical Population Groups for Various Assumed Times of Reentry to Watershed 2 , Route $25 . . . . . . . . . . . . .89$

5.4 Assessments of Estimated Genetically Sigrificant Doses to Critical Population Groups for Various Assumed Times of Reentry to Watershed 2, Route $25 . . . . . . . . . . .90$ 
IIST OF EIGURZS

$\underline{\text { Page }}$

2.1 Map of Panama Illustrating the Route 17 Alignment, Watersheds (numbered 1 through 7), and Locations of Towns and Villages for Estimates of External Dose...... 15

2.2 Map of Colombia Illustrating the Route 25 Alignment and Watersheds (numbered 1 through 5).................. 17

4.1 Evaluation of Potential Daily External Beta Dose to Human Skin.................................. 61

4.2 Total Rstimated Dose to the Total Bcdy for Reentry Times up to 50 Years after the First Detonation, Watershed 5,

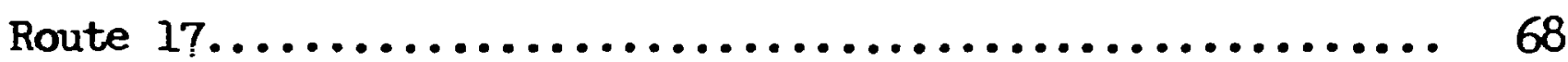

4.3 Total Estimated Dose to the Total Body for Reentry Times up to 50 Years after the First Detonation, Watershed 2,

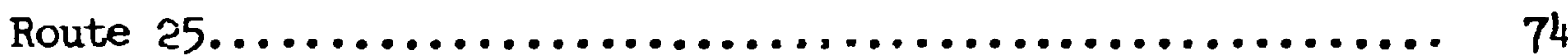

4.4 Graph of Conservatism Factors for Correcting External Dose Estimates that Utilize Racioactive Decay as the O.ly Process to Reduce the Radiation Field............. ${ }^{8}$ 
DOSE-ESTTMATION STUDIES RELATED TO PROPOSED CONSTRLCTION OF

AN ATLANIIC-PACIFIC INIEROCEANIC CANAL

WITH NUCLEAR EXPIOSTVES: PHASE III

Stephen V. Kaye and Pauil S. Rohwer

ABSTRACT

This dooument is the final report covering contributions of the Health Physics Division of Oak Ridge Nationai laboratory (ORNL) to the Bionvironmental Radiological Safety-Feasibility Study of a sea-Ievel canal excavated with nuclear explosives. Potential doses to indigenous populations along Route 17 in eastern Panama and Route 25 in northwestern Colombia were estimated for a combination of hypothetical exposures to radiation. The studies attempted to determine when it might be appropriate for the evacuated populations to reenter areas adjacent to the two routes. The only modes of exposure considered vere external exposure to a contaminated land surface and internal exposure from the ingestion of four types of contaminated foods and beverages. Parameters in the internal dose models were adjusted to aifferentiate five age groups within each of four indigenous populations and nine reference organs. These populations were further differentiated or the basis of diet and estimates of time- and agedependent concentrations of radioactivity in dietary items. Intake finctions ( $\mu \mathrm{Ci}$ ingested per day) for internal dose estimates were average values for watersheds with the highest initial areal concentration of fallout alons each route, whereas external doses were computed for 13 locations (towns and rillages) in watersheds of the exclusion zone of Route 17 only. Estimates of notential external doses were based on 170 radionuciides; oniy 31 radionuslides were considered in defail for the estimation of potential interna? doses, with an approximate estimate of total dose from the radionuclides not included in the list of 31 .

Estimates of potential total doses (intemal dose from ingestion + external dose from land surface) were assesse $\bar{i}$ in terms of radiation safety criteria recommenden for Hewiveris of ine puhlic by recognizen. authorities. The basic criteria were: annua? cuse 
1.1980

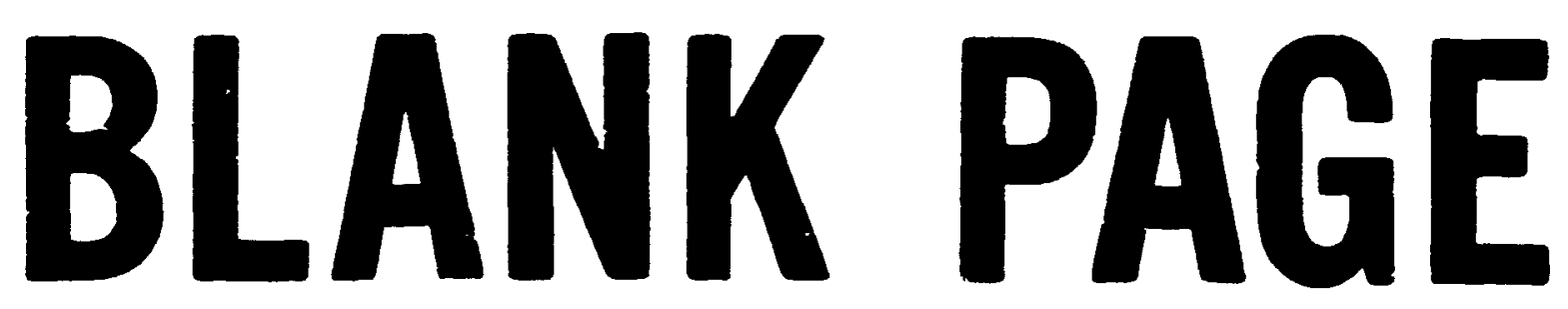


limit for the tota? body of 0.17 rem/year and a genetic dose limit of 5 rems $/ 30$ years. Assessments based on somatic doses suggest reentry may be appropriate 8 to 10 years after the last detonation. Children less than 5 years of age at the time of reentry may be the critical age group among the age groups for which doses were estimated. Within this age group, no single ethnic group emerged as the most critical. Assessments based on genetic dose appear to be less limiting, suigesting that reentry may be possible within months following the last detonation. These assessments are based on comparisons with the total doses allowed under the radiation safety criteria. In actual practice, however, some apportionment of these criteria might be likely. Such an apportionment should be uidertaken by the countries involved (Panama and :olombia). 


\subsection{INIRODUCTION}

\subsection{Isthmain Canai Plans}

The Atlantic-Pacifin Interoceanic Canal Study Commission (APICSC) is sponsoring studies of the engineering, economic, and safety feasibility of excevating a sea-level canal through the Central American isthmus. The APICSC study includes analysis of constructing sea-level canals through the larien region of Panama (Route 17 ) and through northwest Colombia (Poute 25) using a combination of nuclear ar.a conventional excavation. ${ }^{1.1}$

\subsection{Nuciear Sixcavation Concept}

Nuclear excavation of a canal would be ac:complished by detonating rows of buried nuclear charges. These charges would break and throw large quartities of rock and earth out of the excavation in one process, eliminating need for the conrentional earthmoring, and possibly resulting in significant savings in cost. 1.2 A row of nuclear charges, each meeting certain yield limitations and operatioril requirements, would be detonated in a "first pass" series of detonations for each proposed route. Later, these initiai excavation: would be connected to form a continuous ditch by a series of "second pass" detonations. The lasi phase of construction wolld involve opening both ends by conventional excavaiion and äredging. Acceptsble days for nuclear detonation would be determined on the basis of meteorological observations and predictions of radioactive fallout, and areas likely to be 
affected by fallout would be evacuated before construction and for some time thereafter. Nuclear excavation wald be carried out in such a way as to minimize any potentiai exposures of peopie to radioactivity released as a result of the nuclear detonations.

\subsection{APICSC Investigations}

The APICSC asked the U.S. Atomic Energy Commission (AEC) for assistance in determining the engineering feasibility of the proposed project, including safety feasibility, and AEC's Kevada Operations Offics was assigned responsibility for carring it out. Studies related to safety feasibility (i.e., airblast and seismic effects) vere made by various contractor organizations. Airblast effects, seismic effects, fallout predictions, and radiological safety assessment are major areas of concern which were assigned to various prime contractors. Battelle Memorial Institute's Columbus Laboratories (BCL), one of the AEC's prime contractors engaged in this feasibility study, was given responsibility for manaring the bioenvirommental studies required to evaluate radiological safety.

\subsection{BCL Bioenvironmental Feasibility Study}

The major objective of Battelie's work relates to determining if the nuclear excavation plan for construction of a sea-level canal can be carried out safely on the basis of a couparison of predicted radiation doses with established radiation safety standards'. ${ }^{1.3}$ As overall technical anager of the Bioenviromental Feasibility Study, BCL subcontractea specifi: aspects of the 
study such as: humar $\epsilon$ cology; terrestrial ecology, aquatic ecology, marine ecology, dose estimation, hydrology, etc. Data evaluation and enviromental modeling of radionuclide movement through pathrays leading to man was done by BCL. The output of BCL's pathway models was the imput to ORNL's dose estimation codes. Therefore, the imputs used for estimating radiation doses reflected the efforts of all the other subcontractors and BCL. Most subcontractors conducted on-site research in Panama and/or Colombia to gather data pertaining to their areas of responsibility.

\subsection{ORLL Dose Estimation Study}

Three major objectives of the ORIL dose estimation study sere: (1) estimation of potential radiation doses to humans, (2) cumparison of estimatad potential doses with existing standards and guides, and (3) formulation of recommendations to limit potential radiation doses to the lowest practicable levels. Input Agta $\left(\mu \mathrm{Ci} / \mathrm{cm}^{2}\right.$ of land surface and $\mu \mathrm{Ci} / \mathrm{day}$ intekes; were prepared by BCL from the contributions of participating subcontractors and made available to ORIL. Additional input data on biological and Ftojnicg] factorsi required for the computations were compiled by ORNL.

The ORNI. study was divided into the following phases:

$\begin{array}{ll}\text { Phase I } & \text { July } 1,1966 \text { - December 31, } 1966 \\ \text { Phase II } & \text { January } 1,1967 \text { - June 30, } 1968 \\ \text { Phase III } & \text { Juiy } 1,1969 \text { - June 30, } 1970\end{array}$


Phase I studies vere based on literature reviews and data from preliminary reconnaissarce trips by other subcontractors. The ORNL Phase I Report ${ }^{1.4}$ dealt with (1) methods for estimating external and internal dose equivalents, for quantifying the transfer of radionuclides through critical exposure pathways, and for identifying the rautomulides linely to be criticai; (2) criteria for evaiuating the radiological safety of nuclear excavation; and (3) lists of raaionuclides arranged according to doses resulting from external and internal exposures to unit quantities of each radionuclide. Recorenendations of recognized radiation protection authorities were used to develop criteria for assessing the radiological safety cf canal construction.

A continuing effort was underway tirroughout Phase II to develor computer codes for estimating internal and external radiation aoses from canal construction. The outcome was the FNIEM code $f o$ s external dose estimation and the INREM code for internal dose estimation, especially written for modes of exposure expected to be important and requiring the types of infut information expected from other participants in the bicenvironmental study. These codes were used in preliminaij estimates of potential dose to determine the relative importance of une modes of exposure and the relative hazard of various raaionuclides. Both the specific activity ard the environmental systems analysis appsiannes were anaiyzed and tested. Resuits of ORNL's Phase II participation have appeared in six publications. $1.5-1.10$ 
Work in Phase III included inal estirates oi potentia: doses, assessments of these aose e:timates with existine standards and guides, and the formulation of reccumendations. The results of Phase III are repcrted in this docurent.

All aspects of this study could not be sarried out in the most desirable manner. Some modes of expcsure considered to be of potential importince by tilese authors couid not be cunsidered because the necessary inputs were not available. Also, dlanges in source terms and detonation programs made late in this study were not incorporated into the dose estirates listed in this report. 
Re:erences for Chapter 1.0

1.I A. W. Klement, Jr., Radioiogical Safety Research ior Nuclear Excavation Projects - interoceanic Canal Studies, in Froceedings for the Symposium on Public health Aspects of Peace. 'ul Uses of Nuclear Explosives, SWRHL-82, Las Vegas, Nevada, April 7-11, 1969.

I.2 M. M. Wilitamson, Nuclear craterinc Applications, in Proceedings for the Symposium on Public Health Aspects of Peaceful Uses of Nuclear Explosives, SWRHL-8.?, Las Vegas, Nevada, April 7-.11, 1969.

1.3 Battelle Memorial Institute, Bioenvironmental and Radiologicai Safety Feasibility Studies Atlantic-Pacific Interoceanic Canal, BMI-171-003 (January 13, '67).

1.4 K. E. Cowser, S. V. Kaye, P. S. Rohwer, H. S. Snyder and E. G. Struxness, Dose-Esi,imation Studies Kelated to Proposed Construction of an Atlantic-Pacific Interoceanic Canal with Nuclear Explosives: Phase I, ORNL 4101 (March 1967).

1.5 S. V. Kaye and D. J. ivelson, Nuclear Safety 9, 53 (1968).

1.6 W. D. Thriner, S. V. Kaye, and P. S. Rohwer, EXREM and INREM Computer Codes for Estimating Radiation Doses to Pupulations fran Construction of a Sea-Tevel Canal with Nuclea: Bxplosives, K-1752 (September 16, 1968).

1.7 S. V. Kaye and S. J. Ball, "Systems Analysis of a Coupled Compartment Model for Radionuclide Transfer in a Tropical Sinvironment," p. 731 in Symposium on Radioecology ed. by D. J. Nelson and F. C. Evarıs, CONF-670503 (March 1969). 
1..8 S. V. Kaye, ‥ S. Rohwer, K. E. Cowser and W. S. Snyder, Bicડ̄ci. 19 (3), 238 (1969).

1.9 P. S. Rohwer and S. V. Kaye, BioSci. 19 (4), 326 (1969).

1.10 W. D. Turner, The EXREM II Computex fur Estimating

External Doses to Populations from Construction of a Sea-Leve 1

Canal with Nuclear Explosivas, CTC-8 (.July 21, 1.969).

1.11 S. G. Bloom, A. A. Ievin, W. i. Martin, and G. E. Raines, Mathematical Methods for Evaluating the Transport and Accumulation of Radionuclides, BMI-171-030 (April 3, 1.970). 


\subsection{INFORMATION USED FOR RETIMATINC IOSE}

\subsection{Nuclear Explosives snd Kadioiuclide Froruction}

Radionuclide production ( $\mathrm{C}_{i}$ ) from a nuclear craiering detonatica depends on the yield (TNT equivalent) of the aevice, tre fission to fusion ratio, the materials used in constructing the devize, and tho grout, casing, stemming, soil, rock, and moisture at the site of detonation. When all important factors are identified, quantitative redictions can be made of the jẩionuclides that will be produced in a specified cratering detonation. The inventory of radionuclides after detonation includes fissior produets, fusion products, device activation productis, soil and rock astivation products, and residuai fissionable materials. A basic source term list of 318 radionuclides was prepared by BCI from information provided by the Lawrence Radiation Laboratory (LRL) for use in the canal feasibility study.

\subsubsection{Source Term for External Dose}

Radionuclides present in quantities of $1 \mathrm{Ci}$ or less at 1 hour after detonation were deieted by BCL from the basic list of 318 radionuclides. This deletion reduced the source term list to 205 radionuclide;. The list was reduced further to 162 radj onuclides with the elimination of radionuclides having radioactive half-lives of 10 minutes or less. Other considerations resulted in deleting 14 more radionuclides and adding 22 daughter radionus:lides formed from the decay of parents produced by the detonation. Thus, the final source term for the estimation of external dose totaled 170 radionuclides' (see Appendix I). 


\section{1. $\bar{\alpha}$ Scurce Term for Internai Dose}

The basic source term of 318 radionuciides was reducizd by BCL to approximateiy î by timinailike from further internal àuse considerations all radionuclides present ir quartities ff $\bar{i} \mathrm{Ci}$ or less 30 days after each detonaticr. Battelie firther reduced the list of 31 radionuclides on the basis of their cwn estimates of potential internal dose viie to ingestion. These dose estimates were obtained by calculations hased on the specific-activity and standard-man critical-organ concepts, starting with the inventory of raaionuclides present in quantitives freater than $1 \mathrm{Ci} 30$ days after each detonaiion. Results of the calculations led BCL to conclude that approximately $\therefore$ raaiionuclides could be dropped rrom further consideraticn at this step because the total dose commitment would not exceed $I$.em in 70 years. The internal dose estimates presented in this $r$ port are summed dose contributions from tre remaining 31 radionuclides listed in Takle 2.1.

\section{1.j Detonation Programs Assumed for Routes 17 and 25 \\ The detonation frograms assumed for constructing a sea-level canal along Route 17 in Panama and Ro'xte 2.5 in Colombia are shown in Taijle 2.2. Besides being unevenly spaced in time, the yield of individual detonations varies with the excavation requirements of each detonation site.}

Twenty-two detonations are assumed for Route 17, with the last detonation occurring 938 days (2.57 years) after the initial detonation. The time between detonations viries from less than one month for farts of the schedule to 152 days between detonations 10 and $: .1,210$ days between detonations 20 and 21 , and 160 deys between detcnations 21 and 22 . 
Tabie 2.1. Radionuclide Lists for Internal Dose

\begin{tabular}{|c|c|c|c|c|c|}
\hline \multicolumn{3}{|c|}{ ROUTE 17} & \multicolumn{3}{|c|}{ ROUTE 25} \\
\hline${ }^{3} \mathrm{H}$ & $12^{\prime} i_{\mathrm{Te}}$ & $188_{t}$ & ${ }^{3} \mathrm{H}$ & $127 \mathrm{~m} / \mathrm{Te}$ & $185_{W}$ \\
\hline${ }^{14} \mathrm{C}$ & $129 \mathrm{~m}_{\mathrm{Te}}$ & ${ }^{195} \mathrm{Au}$ & $7_{\text {ธิe }}$ & $129 \mathrm{~m}_{\mathrm{Te}}$ & $188_{n}$ \\
\hline${ }^{32} \mathrm{P}$ & $132 \mathrm{Te}$ & $196 \mathrm{Au}$ & ${ }^{14} \mathrm{C}$ & ${ }^{132} \mathrm{Te}$ & ${ }^{195} \mathrm{Au}$ \\
\hline${ }^{89} \mathrm{Sr}$ & ${ }^{131} 1_{I}$ & $203_{\mathrm{Hg}}$ & $32_{\mathrm{P}}$ & ${ }^{131}{ }_{I}$ & ${ }^{196} \mathrm{Au}$ \\
\hline${ }^{90} \mathrm{Sr}$ & ${ }^{141} \mathrm{Ce}$ & $2 \mathrm{iO}_{\mathrm{Pb}}$ & ${ }^{90} \mathrm{Sr}$ & ${ }^{141} \mathrm{Ce}$ & ${ }^{203} \mathrm{Hg}$ \\
\hline${ }^{95} \mathrm{Zr}$ & ${ }^{144} \mathrm{Ce}$ & ${ }^{238} \mathrm{Pu}$ & ${ }^{95} \mathrm{Zr}$ & ${ }^{144} \mathrm{Ce}$ & $210_{\mathrm{Pb}}$ \\
\hline${ }^{35} \mathrm{Nb}$ & ${ }^{143} \operatorname{Pr}$ & ${ }^{239} \mathrm{Pu}$ & ${ }^{103} \mathrm{Ru}$ & ${ }^{143} \mathrm{Pr}$ & ${ }^{239} \mathrm{Pu}$ \\
\hline${ }^{103} \mathrm{Ru}$ & ${ }^{15 l_{\mathrm{Sm}}}$ & $240_{\mathrm{Pu}}$ & ${ }^{106} \mathrm{Ru}$ & ${ }^{147}$ Nd & $240 \mathrm{Pu}$ \\
\hline${ }^{106} \mathrm{Ru}$ & ${ }^{155} \mathrm{Eu}$ & ${ }^{241} \mathrm{Pu}$ & ${ }^{115 m_{C d}}$ & ${ }^{15 \perp_{S \pi}}$ & ${ }^{241} \mathrm{Pu}$ \\
\hline${ }^{124} \mathrm{Sb}$ & 181 & & ${ }^{124} \mathrm{Sb}$ & ${ }^{155} \mathrm{Eu}$ & \\
\hline${ }^{125} \mathrm{Sb}$ & $185_{W}$ & & ${ }^{125} \mathrm{Sb}$ & 181 W & \\
\hline
\end{tabular}


Table 2.2. Detonat1on Programs Assumed for koutes $\therefore$ '7 and 25

\begin{tabular}{|c|c|c|c|c|c|c|}
\hline \multirow[b]{2}{*}{$\begin{array}{l}\text { Detonat 1on } \\
\text { Number }\end{array}$} & \multicolumn{3}{|c|}{ ROUTE 17} & \multicolumn{3}{|c|}{ ROULLE 2.5} \\
\hline & $\begin{array}{l}\text { Days Since } \\
\text { s1rst Detonation }\end{array}$ & $\begin{array}{l}\text { Number of } \\
\text { Devices }\end{array}$ & $\begin{array}{l}\text { Total Y1eld } \\
(M t)\end{array}$ & $\begin{array}{l}\text { Days S1nce } \\
\text { First Detonat I or }\end{array}$ & $\begin{array}{c}\text { Number of } \\
\text { Dev1ses }\end{array}$ & $\begin{array}{l}\text { iotal I1eld } \\
(m t)\end{array}$ \\
\hline 1 & 0 & 6 & 16.0 & 0 & 9 & 9.8 \\
\hline 2 & 38 & 4 & 20.0 & 21 & 4 & 13.0 \\
\hline 3 & 47 & 4 & 17.0 & 45 & 4 & 25.0 \\
\hline 4 & 72 & 4 & 30.0 & 91 & 6 & 14.0 \\
\hline 5 & 95 & 31 & 1.2 .6 & 141 & 4 & 11.0 \\
\hline 6 & 126 & 6 & 9.5 & 170 & 4 & 14.0 \\
\hline 7 & 139 & 1.3 & 5.8 & 1.99 & 5 & iu. \\
\hline$\varepsilon$ & 1.56 & 34 & 11.0 & 380 & 10 & Lueu \\
\hline 9 & 194 & 50 & 7.6 & 395 & 4 & -5.11 \\
\hline 10 & 212 & 10 & 14.0 & 441 & 7 & 10.1 \\
\hline 11 & 364 & 20 & 8.4 & 489 & 4 & 14.0 \\
\hline 12 & 373 & 5 & 12.0 & 511 & 7 & 9.0 \\
\hline 13 & 381 & 4 & 22.0 & 531. & 5 & IU.u \\
\hline 24 & 405 & 10 & 11.5 & 543 & 23 & 11.0 \\
\hline 15 & 452 & 4 & 14.0 & lotal & 86 & 235.8 \\
\hline 16 & 461 & 15 & 12.0 & & & \\
\hline 17 & 490 & 50 & 5.2 & & & \\
\hline 18 & 508 & 50 & 8.8 & & & \\
\hline 19 & 527 & 10 & 10.5 & & & \\
\hline 20 & 566 & 7 & 10.0 & & & \\
\hline 2.1 & 776 & 50 & 10.4 & & & \\
\hline \multirow[t]{2}{*}{22} & 938 & 50 & 7.5 & & & \\
\hline & rotal & 437 & 274.8 & & & \\
\hline
\end{tabular}


Although only 14 detonations are assumed for Route 25, the schedule is divided into two passes, the first terminating after 199 days and the second beginning 181 days later and terminating 543 days after the first detonation.

\subsection{Locations for Computing Dose}

Patterns and levels of fallout that might result from nuclear excavation of a canal aiong Routes 17 and 25 were computed jy the Environmental Science Services Administration (ESSA). Later, ESSA revised their estimates after establishment of a revised detonation program. The predicted levels of contamination present at each of the fallout contour lines were used by ESSA to escimate the potential cumulative garma exposure resulting after 70 years at a height of 3 ft above the land surface. The exclusion boundary that was selected lies outside the $0.1 \mathrm{R}$ contour for a 70-year exposure to external gamma radiation from the landsurface. Theoretically, if ESSA's predicted exposures are realistic and if populations are evacuated from the exclusion area diring and following canal construction, no individual or population group would be expected to receive a lifetime external ganma exposure greater than $0.1 \mathrm{R}$. Figures 2.1 and 2.2 show the location and extent of : $35 A^{2}$ s exclusion area for Routes 17 and 25, respectively.

\subsubsection{External Dose (Route 17)}

Thirteen locations (Fig. 2.1), all witisin the exclusion zone, were evaluated for external dose and dose rate with the EXREM code. Since resident populations will be evacuated from the exc.iusion zone before the first detonation, estimates of external dose are important 
ORNL-DWG 70-2527R

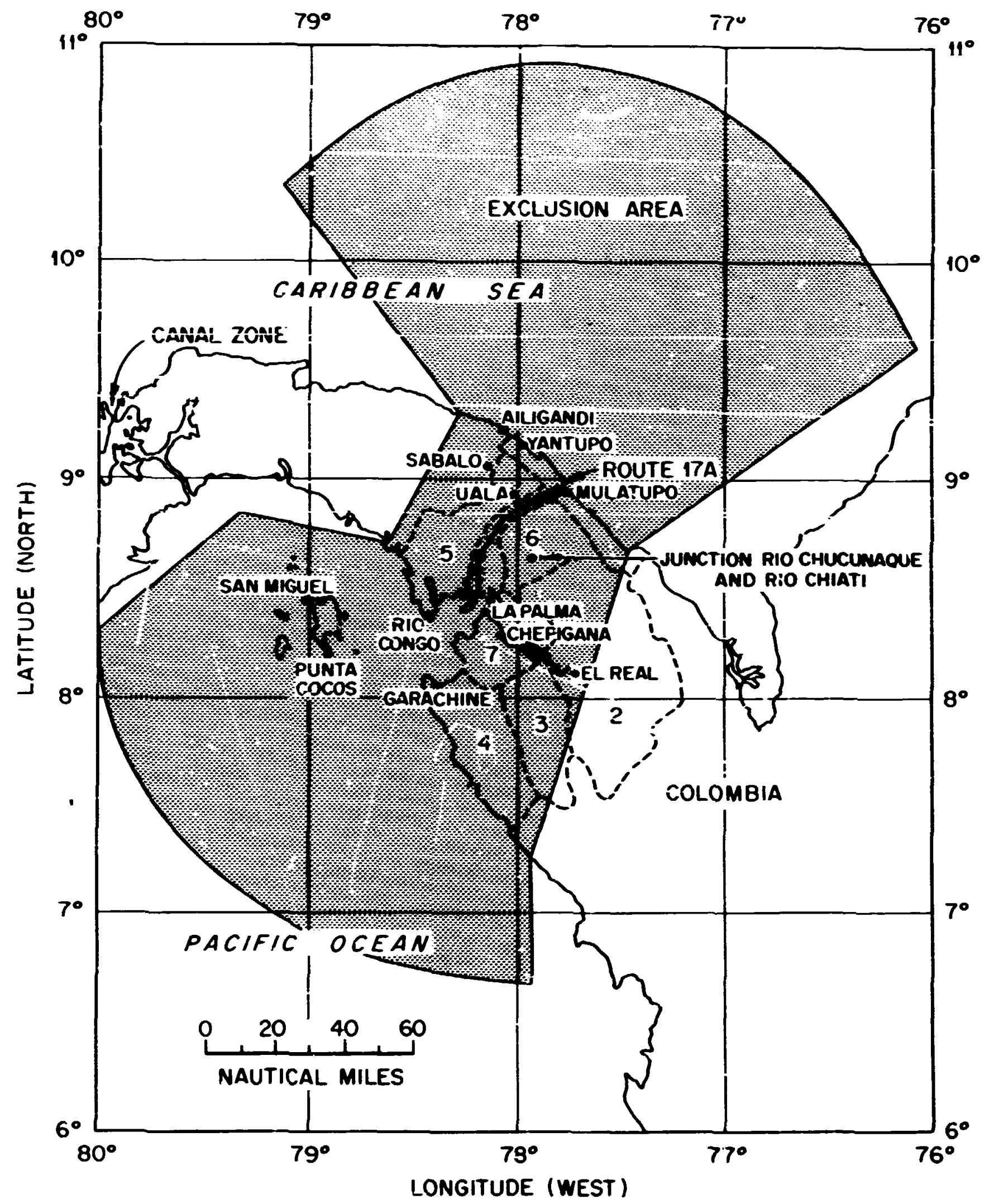

Fig. 2.1. Map of Panama Illustrasing the Route 17 Alignment, Watersheds (numbered 1 through 7), and Locations of Towns and Villages for Estimates of External Dose. 
primarily fur two considerations: 1) determination of the radioiogical safety for construction personnel and 2) as an aid to determination of the time when the resident population may return to each location.

Battelle Columbus Laboratories multiplied the quantity of each radionuclide produced at the time of each detonation by an assumed Iocal fallout fraction of 15 percent and a factor representing the fraction of the fallout pattern deposited on a unit area basis at each of the 13 pcint locations. The 13 point locations were superimposed on a map cf ESSA's fallout fraction contours enclosing each location and the higher of the two failout contours was used by BCL to compute areal deposition on the land surface in $\mu \mathrm{Ci} / \mathrm{cm}^{2}$. This selection of the higher contour value can result in an overestimate of dose by as much as a factor of 10 , which is the greatest difference between fallout fractions for two contours enclosing any of the 13 locations.

\subsubsection{Internal Dose (Routes 17 and 25)}

Land areas adjacent to the two proposed canal alignments were divided into watersheds by BCL, and ESSA's fallout contcurs were used to compute an average radionuclide concentration on the lana surface of each watershed. These watersheds are outlined by dashed lines in Fig. 2.1 (Route 17) and Fig. 2.2 (Route 25). Internal dose was estimated for the watershed along each route predicted to have the highest initial fallowi concentration on the land surface, e.g., watershed 5 for Route 17 and watershed 2 for Route 25 . Since no unique physiographic or biotic factors were considered in sctimating poteitial internal doses to residents of these two watersheds, 
ORNL-DWG 70-2528

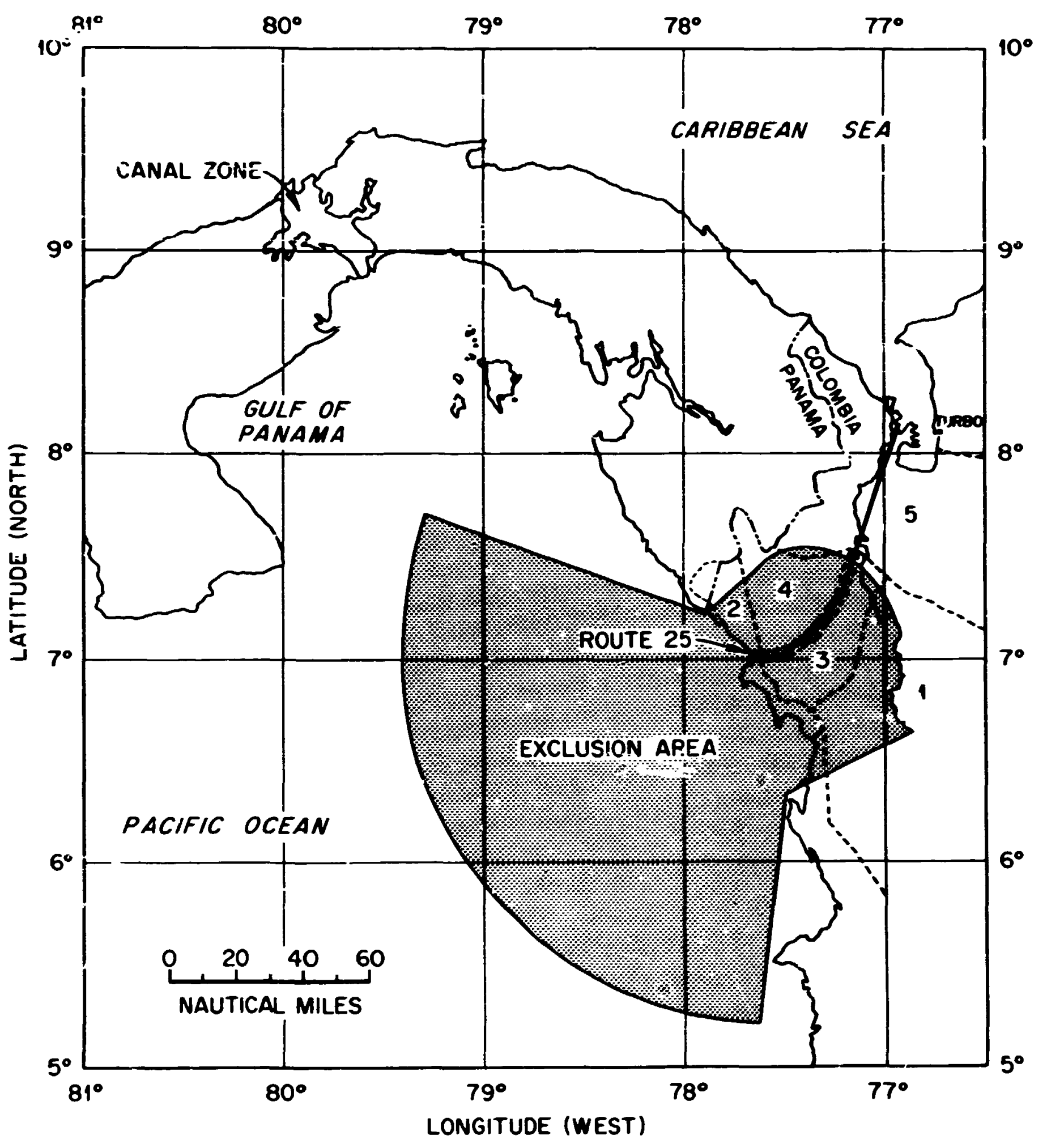

Fig. 2.2. Map of Colombia Illustrating the Route 25 Alignment and Watersheds (numbered 1 through 5). 
tile initial average fallout consentrations sere rormaiized to watershed 5 for Route 17 and watershed $\varepsilon$ for Koute 25 to derive a table of factors to extrapolate doses to all other watersheds (see Table 2.3).

Radioactivity intakes leading to internal exposures wer? assumed to resuit from a composite diet representing food and beverages collected from the entire watershed. Mhis, our calcuilsted internal doses are average values for the entire watershed and are not related to any particular point location within the watershed. This is in contrast to the use of point locations (towns and villages) for the computation of potential external doses.

\subsection{Modes of Exposure}

\subsubsection{External Exposure (Route 17)}

A "mode of exposure" is the manner in wich a person is exposed. Originally, it was hoped that input would be provided to estimate potential external doses from three modes of exposure: exposure above a contaminated land surface, submersion in a radioactive "cloud," and submersion in contaminated water. Although the EXREM code was develored to compute external doses for all three modes of exposure, BCL program changes limited input data only to exposure above a contaminated land surface, and this only for Route 17. In view of time and budget limitations, the ctirer two modes of exposure were not consiüered.

The duration of potential submersion in a radioactive "cloud" is limited to the length of time required for the cloud to pass over the location of interest. This cime may range from less than one hour 
Table 2.3. Correcticn Factors Corfiled by BCL for Estimatine Fotential Baciation irses in Different niztersheds :Ear Routes I: and $25^{a}$

\begin{tabular}{ccc}
\hline Watershed & \multicolumn{2}{c}{ Correction Factor } \\
\hline 5 & Route 17 & Route 25 \\
6 & 1.00 & $\ldots$ \\
7 & 0.995 & $\ldots$ \\
1 & 0.437 & -- \\
4 & 0.284 & 0.0000964 \\
2 & 0.0158 & 0.474 \\
3 & 0.00105 & 1.000 \\
& 0.000263 & 0.826 \\
\hline
\end{tabular}

${ }^{\text {A. }}$ comparable correction factor for areas correspcnding to the 0.1 Roentgen exposure contour designated by ESSA equals 0.0013 for Route 17 and $0.0005 C 5$ for Route 25 . The decimal places are not indicative of accuracy. 
to approximately one day, depending upon weather conditions and distance from the caras. In any event, the duration of submersion, and hence exposure, is rezatively short since peole \%ill be cvacuateü from tise area expected to be covered by local falluut while the nuclear exravation is bein̈ carried cus, suomersion in the "cloua" is not anticipated unless the "cloud" or "clouis" fail to disperse as predicted. In contrast, some finite exposiure to contaminated landscape is pussible, even many years after people return to the excl.ision area. At the time of reentry, rivers and streams should be flushed of almost all fajout radioactivity, so that even a high use factor for surface water may no: result in an appreciatle external dose from submersior in contaminated water.

Host radiological safetiy assessments do not consider the potential extermal dose from beta emitters deprsited on lands sape vecause clotilnt und other merials provide adequate shielding. Since many Panamanians and Colombians wear little clothine, it may be important to estimate exposures to skin from beta emitters. Mie Cuna Indians of the San Blas Islands and the mainland of eastern Pusuma save the nighest incidence of albinism in the world, representine a potential.ly "critical" population group for beta skin doses. The albincs numbered approximately 150 individuals in $1962 .{ }^{2.1}$ They are considered to be especially suscentible to the effects of skin irradiation because they have a high incidence of chronic skin lesions caused by sunburn. Seborrheic keratoses, solar elastoses, and carcincmas of squamous and basal celi urigin have been roported as commonly occurring in Cuna Albinos. $2.2,2.3$ Therefore, we undertook to estimate dose to the skin from beta emitters deposited directly on the skjn and on the lar.d surface. 
2.3.2 Internal Exposure (Routes 17 and 25)

Ingestion and inhalation are the primary moues of internal cxposure fullowing reiease of radisactivity to the envirorment. There are additional modes of inte:zal exposure but they are of less importance generally; absorption of radionuclides through the skin and entry thrcugh wounds are examples.

Radionuclide intake rates via ingestion ( $\mu \mathrm{Ci} / \mathrm{day}$, as a function of age- and time-dependent variations) were provided for internal dose estimations with the INREM computer code. These input data for IIREM were BCL's estimates of radionuclide intakes which could result from the consumption of contaminated foods and beverages (animals other than fish, fish, piant edibles, and water) by people living near Routes 17 and 25. Input data for other modes of internal exposure were not available because of program limitations, but ingestion is probably the most impcrtant internal exposure mode in any case. That is, if one assumes that evacuation of the exclusion area is successful in preventing innalation exposures. However, it is important ic note that the evaluation of only one internal exposure mode may result in an underestimate of the potential interral radiation dose.

\subsection{Population Data for Estimatins Genetically Signif:cant Dose}

Parameters in the model used to estimate the genetically significant dose were evaluated for both routes with the Panamanian data of Arauz. ${ }^{2.4}$ Sufficient demographic data were not provided to complete a unique evaluation for populations living in 
tine vicinity oi houte 25 in Colombia. The territory studied by Arauz covers 23,000 square kilometers and, according to the $i 90$ census, has 25,700 invaititants of various ethnic backorounds. A nonraidom sample: including scme 1,400 houses and approximately 8,400 individuals among these ethnic groups, were examined. Four clearly distinct populations were identified: Cura Indians, Choco Indians, Negroes, and Colonists. Breakdiun of the sample wes as foliows:

$\begin{array}{lrrr}\text { Population } & \text { Men } & \text { Women } & \text { Totai } \\ \text { Cuna Indians } & 1,200 & 1,300 & 2,500 \\ \text { Choco Indians } & 1,400 & 1,200 & 2,600 \\ \text { Negroes } & 1,300 & 1,200 & 2,500 \\ \text { Colonists } & 4,300 & 4,100 & 8,400\end{array}$

Details concerning age distribution and birth rate for each population are sumarized in Table 2.4. It is assimizu that the

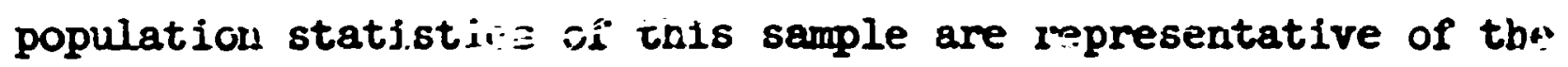
respective populations. The birth rate ralues in Table 2.4 are specific for females; however, in the absence of better informattsis, the same values were also spijici to the male population when estimating genetically significant dose.

\subsection{Age-Dependent Parameters for Intemal Dose}

A inorough assessment of popuiation exposures yould require radiation dose estimates for each individual or for each critical segment or group is the wole populaticin. 
Table 2.4. Age Distributions and Birtl: Rates for Populations Indigerious to Route 17

\begin{tabular}{|c|c|c|c|c|c|c|c|c|}
\hline \multirow[b]{3}{*}{$\begin{array}{c}\text { Age } \\
\text { Range } \\
\text { (year8) } \\
\end{array}$} & \multicolumn{8}{|c|}{ Ayse D1stribution \& B1rth Rate } \\
\hline & \multicolumn{2}{|c|}{ Cuna Indians } & \multicolumn{2}{|c|}{ Choco Irdians } & \multicolumn{2}{|c|}{ Negros:s } & \multicolumn{2}{|c|}{ Coloniste } \\
\hline & $\begin{array}{l}\text { Percent } \\
\text { of Cuna } \\
\text { Population } \\
\end{array}$ & $\begin{array}{l}\text { Birth } \\
\text { Rate }\end{array}$ & $\begin{array}{l}\text { Purcent } \\
\text { of Choco } \\
\text { Population }\end{array}$ & $\begin{array}{c}\text { Birtha } \\
\text { Rate }\end{array}$ & $\begin{array}{c}\text { Fercent } \\
\text { of Negro } \\
\text { Populat Ion } \\
\end{array}$ & $\begin{array}{l}\text { B1rtha } \\
\text { Rate }\end{array}$ & $\begin{array}{l}\text { Percent } \\
\text { of Colonist, } \\
\text { Forilation }\end{array}$ & $\begin{array}{l}\text { Bir ; } \mathrm{h}^{\mathrm{a}} \\
\text { Rat: }\end{array}$ \\
\hline$<5$ & 16.5 & 0 & 21.2 & 0 & 20.5 & 0 & 2.1 .7 & 3 \\
\hline $5-9$ & 16.9 & 0 & 16.8 & 0 & 30.3 & 0 & 18.6 & 0 \\
\hline$i u ́-14$ & 13.4 & 0 & 13.3 & 0 & 14.1 & 0 & 22.1 & 0 \\
\hline $15-19$ & 10.4 & 0.18 & $i 0.6$ & 0.26 & 7.5 & 0.29 & 8.0 & 0.23 \\
\hline $20-24$ & 7.8 & 0.30 & 8.1 & 0.39 & 6.2 & 0.41 & 7.8 & $C .36$ \\
\hline $25-29$ & 8.2 & 0.27 & 7.5 & 0.34 & 4.8 & 0.36 & 9.9 & $(.31$ \\
\hline $30-34$ & 7.7 & 0.20 & 5.6 & 0.23 & 5.2 & 0.22 & 5.7 & 11.21 \\
\hline $35-39$ & 5.7 & 0.13 & 4.8 & 0.13 & 5.0 & 0.09 & 5.4 & 0.12 \\
\hline $40-44$ & 3.7 & 0.06 & 2.7 & 0.07 & 3.4 & 0.04 & 2.3 & J.05 \\
\hline $45-49$ & 3.1 & 0.02 & 2.7 & 0.02 & 4.0 & 0.02 & 3.5 & 0.02 \\
\hline$>50$ & 6.5 & 0 & 6.7 & 0 & 8.9 & 0 & 4.9 & 0 \\
\hline
\end{tabular}

Q Birth rate $=1$ live bixths per year per woman. 
A practical approsh to such ail assessanent is to divide the population into groups, the grouns being small and homogeneorls with respect to the factors which influence ause. Afo is an important factor in this regard, and, although other differentiating factors may also be operative, age is a convenient characteristic with which to differentiate population groups. Therefore, the indigenous populations in Panama and Colombia were divided into five age groups: 0 to 1 year, 1 to 5 years, 5 to 10 years, 10 to 15 years, and greater than 15 years. These age intervals were seiected jointly by ORKL and BCL, with cognizance of the dietary data provided by Arauz, and McBryde and Costales. $2.5,2.6$ The paucity of information describing human populations in Panana a - Cclombia and their age-dependent characteristics led to heavy reliance on the tabulated values of "standard" man, 2.7 even for this limited age breakdown, recognizing that populations in Central America may differ considerably from "stardard" man. Differences among the four ethnic groups are reflected in their daily intakes of radioactive materials.

Age-dependent dose estimates were obtained with the INREM code for total body, bone, liver, thyroid, testes, ovaries, lungs, kidneys, and G.I. trac.t. Organs were selected on the tasis of the importance of estimates of their doses to a radiological safety assessment, and the availability of information to complete organ-specific dose calculations. In those instances where it was desirable to estimate the dose to an organ for which an organ-specific dose estimate was not provided by the INREM code, estimated total-body dose was applied. Estimation of dose to bone due to tritium was an exception, in that case one-fourth of the total-body dose was applied. Tritium was assumed to be present in 
the body as ETO, and to be in equilibrium with the body water pool. Dose to an organ dive to irio was assumed to be proportional to the percent water content (by weight) of that organ. Most tissies and organs are approxirately 60 to 80 fercent water; bone is an exception, being approximately 20 perent water. 2.8

Dose estimation minels in the INREM code can utilize agedependent information for organ mass (m), eifartive aksorbed energy ( $\epsilon)$, fraction of radionuclide intake reaching the reference organ (f). effective half-time of the radioruclide in the reference organ $\left(\mathrm{T}_{\mathrm{e}}\right)$, and daily iadionuclide intake $(I)$. The following sections outline tice rationale used to determine the values of these agedependent parameters.

\subsubsection{Organ Mass}

Values chusen for organ mass as a function of age were based on literature describing the Caucasian population from which values for standard man are drawn. Caucasian population values for all age groups except the 0 to 1 year olds were reduced 20 percent to account for the smaller physical size observed in those groups in.

Central American populations..$^{2.9}$ A notable excertion is the thyroid, in which case no mass reduction was made because of the high incidence of goiter. 2.9 Individuals achieve adult physical maturity by the age of 15 years. The values for organ mass are tabulated in Table 2.5.

\subsubsection{Effective Absorbed Entrgy}

Effective absoibed energy contributions of all radiation emissions, except ganma and $x$-ray phcions, were assumed to be independent of the age of the individual exposed. Preliminary results 
I'asle 2.5. Varlations in Organ Mass as a Function of Age

\begin{tabular}{|c|c|c|c|c|c|}
\hline \multirow[b]{2}{*}{ Body Organ } & \multicolumn{4}{|c|}{ Organ Mas3 (g) } & \multirow{2}{*}{$\begin{array}{l}\text { greater } \\
\text { than } \\
15 \text { years }\end{array}$} \\
\hline & C-1 year & $1-5$ years & $5-16$ year's & $10-15$ yeurs & \\
\hline Total Body ${ }^{a}$ & 7,800 & 11,600 & 20,400 & 34,400 & $.5,000$ \\
\hline Bone $b, c$ & 500 & 800 & $2, .20$ & 2,720 & 3,800 \\
\hline Ifver ${ }^{d, e}$ & 230 & 400 & 500 & 800 & 1,440 \\
\hline K1dneys ${ }^{f}$ & 50 & 80 & 110 & 150 & 240 \\
\hline Thyrold ${ }^{B}$ & 2.0 & 2.5 & 5.0 & 11.3 & 16.0 \\
\hline Testes ${ }^{\text {' }}$ & 3.4 & 3.4 & 4.2 & 3.2 .0 & 32.0 \\
\hline Ovartes ${ }^{e}$ & 0.4 & 2.0 & 2.0 & 4.8 & 8.0 \\
\hline Lungs ${ }^{h}$ & 120 & 190 & 300 & 410 & 800 \\
\hline \multicolumn{6}{|l|}{ GI Tract (Contents) $1, j, k$} \\
\hline St.omach & $\geqq 8$ & 50 & 88 & 136 & 200 \\
\hline Sniall Intestine & 60 & 101 & 129 & 181 & 320 \\
\hline Liper Large Intestine & 33 & 55 & 71 & 99 & 176 \\
\hline Lower Iarge Intestine & 20 & 34 & 44 & 61 & 308 \\
\hline
\end{tabular}


Table 2.5. (cont'd)

a. W. Stolidt, A. Damon, and R. A. McFarland, Kluman Blology 22, $3: 1$ (1960).

b. Muhlmann, Ergebn. A. Anat. u. Entwicklunigsgessh 2.7, 1 (1927).

c. G. Robertson, "Developmental Anatoiny," F. 9i? in Morris Human Ajratomy, li.th ed., ed. by B. J. Anson, MeGraiv-H1ll, New York (1966).

QE. Boyd, Arch. Pathol. 16, 350 (1933).

EE. R. Roessle and F. Roulet, Maiss und Zahl in der Patholog1e, Surjinger-Verlag, Berlin (193a).

frh1te House Conference, p. 509 (1933).

B. Mochizuk1, K. Mowafy, and B. Pastejnack, Health Phys1cs 2, 1299 (1963).

hE. Boyd, An Introduction to Yuman B10J.0gy and Anatomy for F1rst-Year Med1cal Students, Lept. for Study of Human Growth, thiversity of Colorecio School of Medic1ne (1952).

$1_{R}$. E. Scarmon, Amer. J. of Diseases of Ch1ldhood 17, 395 (1919).

$I_{R}$. E. Scammon, The Measurement of the Body In Ch1lahood, Un1v. of Minnesota Fress (1930).

k. S. Eve, Health Physiss 1ૃ, 131 (1966). 
from energy absorption studies being conducted in the Health Physics Division at ORNL suggest that absorbed fractions within organs for gamma and $x$-ray photons are approximately proportionnl to the onethird power of organi ivass. 2.10 Tuerefurc, the effecivive absorbed energy contributicns of those photons are adjusted in proportion to the one-third power of the ratio of organ mass for a given age group to the mass of the respective organ of "standard" man given in ICRP Publ. 2.2.7 Data given for the G.I. tract are appropriate for the segments fdentified in ICRP Publ. 2 as critical for the respective radionuclides. The values of effective absorbed energy are listed in Table 2.6.

\subsubsection{Fraction of Intake Reaching Organ of Reference}

There is little information available on the age-dependent variation of radionuclide uptake by body organs. Adequate data are not available for specific age-group evaluations for most radionuclides under consideration, and, in those cases, standsrd-man values were

applied to all age groups. 2.7 The fractional uptake values used, which differ from those for "standard" man, are presented in Table 2.7. The application of standard-man values to all age groups is not conservative necessarily; horever, it does not ssem prudent to use other values without supporting literature. In those cases where uptake fractions for standard man are large (approaching 1.0) the values may be applied to younger age groups with confidence. However, when uptake fractions for standard man are smaller, application of the values to younger age Groups must be done with greater reservation, because there is no certalnty that body processes controlling uptake are equally discrimInating for all age groups, particularly for infants. 


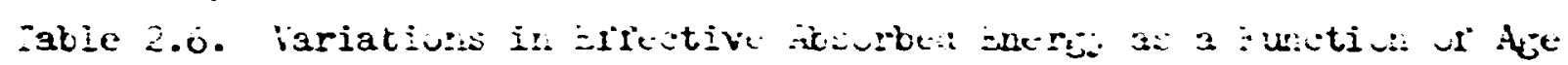

\begin{tabular}{|c|c|c|c|c|c|c|}
\hline \multirow[b]{2}{*}{$\begin{array}{l}\text { Radjo- } \\
\text { nuclide }\end{array}$} & \multirow[b]{2}{*}{ Eocis ortan } & \multicolumn{5}{|c|}{ 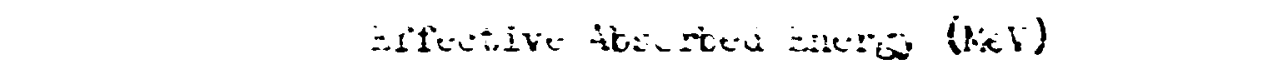 } \\
\hline & & U-1 year & $\Sigma-5$ jea: & $\bar{j}-i \cup y t=a r$ & iv-15 years & $\begin{array}{l}\text { ortater } \\
\text { tinan } \\
15 \text { years }\end{array}$ \\
\hline \multirow{6}{*}{95} & Dotal Eody & 0.62 & $0.60^{\circ}$ & $\therefore 73$ & $2.8 y$ & $1.0 i$ \\
\hline & Bone & $\therefore$ & $i .05$ & 1.00 & 1.09 & 1.10 \\
\hline & Isiver & 0.39 & 0.4 & $C .47$ & $ن .50$ & 0.56 \\
\hline & Kinne js & 0.32 & 0.34 & 0.35 & 3.37 & 0.40 \\
\hline & 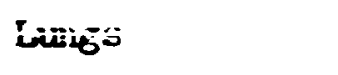 & i. & $0 . \therefore$ & 0.4 & $\because \therefore$ & $a .51$ \\
\hline & iI Iract & $0.2^{\prime} i$ & 3.20 & $\therefore .79$ & 0.32 & J.34 \\
\hline \multirow{6}{*}{$95_{17 b}$} & Fotal Body & 0.28 & $0.3:$ & 0.36 & 0.42 & 0.47 \\
\hline & Bone & 0.33 & 0.34 & 0.34 & 0.35 & 0.36 \\
\hline & Ifrer & 0.17 & 0.19 & 0.21 & 0.22 & 0.25 \\
\hline & Kidneys & 0.14 & 0.15 & U.iv & 0.17 & 0.19 \\
\hline & Larites & 0.16 & 0.18 & 0.20 & 0.21 & 0.25 \\
\hline & GI iract & 0.11 & 0.12 & 0.13 & $0.1 \div$ & 0.15 \\
\hline \multirow{5}{*}{${ }^{103} \mathrm{Ku}$} & Fotal Body & 0.26 & 0.28 & 0.32 & 0.37 & 0.42 \\
\hline & Eone & 0.56 & 0.57 & 0.58 & 0.59 & 0.60 \\
\hline & Klòneys & 0.15 & 0.16 & 0.17 & 0.18 & 0.22 \\
\hline & Lungs & 0.16 & 0.17 & 0.18 & 0.20 & 0.23 \\
\hline & GI Iract & 0.16 & 0.17 & 0.18 & 0.18 & 0.20 \\
\hline \multirow{5}{*}{$106 \mathrm{Ru}$} & Sotal Budy & 1.37 & 1.39 & 1.39 & 1.40 & 1.40 \\
\hline & Bone & 6.5 & 0.5 & 6.5 & 6.5 & 6.5 \\
\hline & KIdneys & 1.33 & 1.33 & 1.34 & 1.34 & 1.35 \\
\hline & Lungs & 1.33 & $i .36$ & 1.35 & 1.35 & 1.36 \\
\hline & GI iract & 1.32 & 1.32 & 1.33 & 1.33 & 1.33 \\
\hline \multirow{6}{*}{12450} & Total Body & 0.93 & 1.03 & $1.1 \%$ & 2.33 & 1.51 \\
\hline & Bone & 1.86 & 1.91 & 1.95 & 2.09 & 2.16 \\
\hline & LIyer & 0.63 & 0.59 & 0.14 & 0.79 & 0.89 \\
\hline & Thyrold & 0.43 & 0.46 & 0.48 & 0.53 & 0.57 \\
\hline & Lune: & 0.60 & 0.60 & 0.72 & 0.70 & 0.89 \\
\hline & GI iract & 0.50 & 0.56 & 0.50 & 0.53 & 0.0 .00 \\
\hline
\end{tabular}


$a \operatorname{ar}:=2.6 . .0 x=1 \pm$.

\begin{tabular}{|c|c|c|c|c|c|c|}
\hline \multirow[b]{2}{*}{$\begin{array}{l}\text { Radio- } \\
\text { nucifide }\end{array}$} & \multirow[b]{2}{*}{ Eody Orgar. } & \multicolumn{5}{|c|}{ 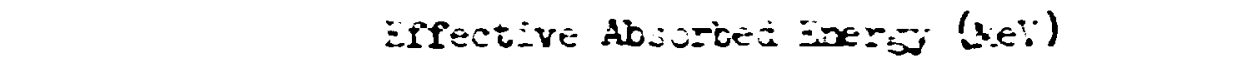 } \\
\hline & & $j-i$ jear & L-5 jear: & 5 -iv jears & iu-15 jears & $\begin{array}{c}\text { Ereater } \\
\text { tian } \\
\text { i5 years }\end{array}$ \\
\hline \multirow{6}{*}{125} & Jutal Eudy & 0.22 & 0.24 & 0.27 & j.3i & ن.35 \\
\hline & Bone & 0.50 & 0.52 & 0.53 & 0.57 & 0.58 \\
\hline & Liver & 0.16 & $0 . \bar{I} \hat{E}$ & 3.19 & 0.20 & 0.22 \\
\hline & Thyroid & $0.1 i$ & 0.12 & 0.12 & $0 . i j$ & 0.15 \\
\hline & Lrefes & 0.15 & $0.1 ?$ & 0.18 & j.15 & 0.22 \\
\hline & GI iract & 0.22 & 0.24 & 0.26 & 0.28 & 2.30 \\
\hline \multirow{8}{*}{$127 \mathrm{Te}$} & Total Body & 0.27 & 5.22 & 0.29 & 2.30 & 5.32 \\
\hline & Bone & 1.24 & $1.2 \%$ & 1.30 & 1.38 & 1.42 \\
\hline & Liver & 0.27 & 0.28 & 0.29 & 0.30 & 0.32 \\
\hline & Kiòneys & $0.2 \%$ & 0.28 & 0.29 & 2.30 & 0.32 \\
\hline & ithyroic & 0.26 & 0.26 & 0.27 & 3.29 & 0.30 \\
\hline & Fesies & 0.26 & 0.26 & 0.26 & 0.28 & 0.31 \\
\hline & Lungs & 0.27 & 0.28 & 0.29 & 0.30 & 0.32 \\
\hline & II Iriant & 0.28 & 0.29 & 0.30 & 0.31 & 0.32 \\
\hline \multirow{8}{*}{$129 \pi$} & $\because$ otai Ech & 0.82 & 0.87 & 0.92 & 0.98 & 2.05 \\
\hline & Bune & 3.1 & 3.1 & 3.1 & 3.2 & 3.2 \\
\hline & Lfer & 0.77 & 0.74 & 0.76 & 0.7 & 0.82 \\
\hline & KAáreys & 0.70 & 0.7 & 0.72 & 2.74 & 0.76 \\
\hline & Thay roid & 0.64 & 0.064 & 0.65 & 0.067 & $0 . \leqslant 0$ \\
\hline & Festes & 0.64 & 0.64 & 0.64 & 0.66 & 0.67 \\
\hline & $\operatorname{Lung} 5$ & 0.71 & 3.74 & 0.76 & 0.77 & 0.22 \\
\hline & GI Trest & 0.64 & 0.67 & 0.69 & 0.70 & 0.75 \\
\hline \multirow{8}{*}{132 Te } & Total Body & 1.16 & 1.26 & 1.42 & 1.50 & 1.80 \\
\hline & Borie & 2.67 & 2.72 & 2.76 & 2.90 & 2.96 \\
\hline & Liver & 0.80 & 1.86 & 0.92 & 0.96 & $1.0 ?$ \\
\hline & Kidneys & 0.74 & 0.79 & 0.32 & 0.86 & 0.92 \\
\hline & Fnyróa & 0.60 & 0.61 & 0.64 & 0.7 & 0.72 \\
\hline & تestes & 0.59 & 0.59 & 0.60 & 0.65 & 0.71 \\
\hline & Lung: & 0.77 & 0.34 & 0.90 & 0.96 & 1.07 \\
\hline & GI Jract & 0.61 & 0.64 & 0.66 & 0.70 & 0.90 \\
\hline
\end{tabular}




\begin{tabular}{|c|c|c|c|c|c|c|}
\hline \multirow[b]{2}{*}{$\begin{array}{l}\text { Susi- } \\
\text { suelice }\end{array}$} & \multirow[b]{2}{*}{ 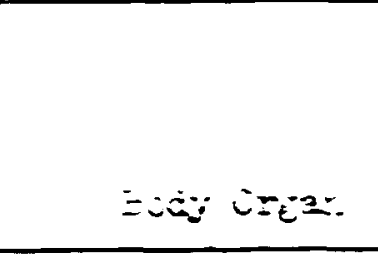 } & \multirow[b]{2}{*}{$\therefore y=$} & \multicolumn{3}{|c|}{ 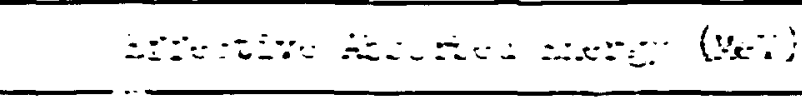 } & \multirow{2}{*}{ 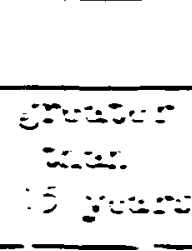 } \\
\hline & & & $--5 \because \because=2$ & $\equiv-2, y=$ & - & \\
\hline \multirow{4}{*}{$\therefore:-$} & こニta & $\cdots=$ & زذز.. & $\ldots .5$ & $\ldots$ & زד.. \\
\hline & $\because 0 \mathrm{roz}$ & i.Zi & $\ldots z$ & $\ldots$ & $\ldots$ & $\ldots$ \\
\hline & ع & $\therefore .25$ & $\therefore \therefore$ & $\therefore . \cdots$ & $\ldots=$ & . \\
\hline & :I raet & $j .2 j$ & $0.2=$ & $\ldots$ & $\therefore . .-4$ & $\ldots=$ \\
\hline \multirow{6}{*}{ 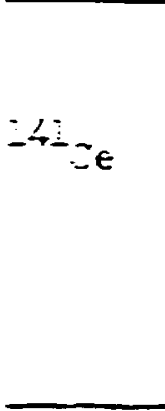 } & Lotai 三ody & 0.19 & 5.29 & $\ldots$ & $\cdots:$ & $\therefore=2$ \\
\hline & Es:e & 0.51 & 2. & $\therefore E$ & 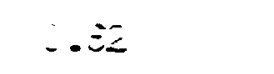 & $0.2=$ \\
\hline & LEx & $\therefore .2 \Sigma$ & $\therefore \therefore$ & U.ZE & $\therefore \therefore$ & i.iy \\
\hline & Kianeys & 0.17 & U. & J.iE & .is & U. \\
\hline & jurigs & 0.17 & j.is & 2.13 & j.20 & j.i3 \\
\hline & is iract & 0.17 & 0.17 & 0.17 & 3.17 & 0.27 \\
\hline \multirow{5}{*}{$144 \mathrm{ce}$} & 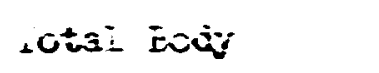 & 1.26 & 2.27 & $\therefore .25$ & $1.2:$ & $\therefore .27$ \\
\hline & Eone & 6.25 & 6.25 & 0.25 & 6.05 & 6.25 \\
\hline & Liver & 1.26 & $i .26$ & 2.26 & $\therefore .2 E$ & 1.26 \\
\hline & Lungs & $\therefore .26$ & 1.26 & 1.26 & $\therefore .26$ & $i .26$ \\
\hline & II iract & 1.26 & 1.26 & $i .26$ & 1.20 & i.26 \\
\hline \multirow{6}{*}{${ }^{15 I_{\mathrm{Si}}}$} & Totai ind & 0.032 & 0.034 & 0.036 & 0.039 & 0.041 \\
\hline & Bone & 0.12 & 0.23 & 0.13 & 0.13 & 0.33 \\
\hline & Liver & 0.033 & 0.035 & 0.037 & 0.038 & $0.04 i$ \\
\hline & Kidneys & 0.032 & 3.034 & 0.036 & 0.039 & $0.0<1$ \\
\hline & $-1 ; m_{i}=$ & ก.กร? & 0.036 & 0.036 & 0.037 & 0.041 \\
\hline & GI Iract & 0.032 & 0.034 & 0.035 & 0.037 & 0.039 \\
\hline \multirow{6}{*}{155 Eu } & íctal fody & 0.11 & 0.12 & 0.13 & 0.14 & 0.16 \\
\hline & Sone & 0.27 & 0.27 & 0.27 & $\because .28$ & 0.28 \\
\hline & LEvver & $0.67 j$ & 5.078 & 0.00 & 0.085 & 0.593 \\
\hline & Kidneys & 0.063 & 0.071 & 0.073 & 0.076 & 0.080 \\
\hline & Lungs & 0.072 & 0.076 & 0.080 & 0.034 & 0.093 \\
\hline & GI lract & 0.063 & 0.066 & 0.067 & 0.669 & 0.072 \\
\hline \multirow{5}{*}{181} & Fotai sody & 0.30 & 0.12 & 0.14 & 0.16 & 0.19 \\
\hline & Eone & 0.020 & $0.02 \overline{3}$ & 0.026 & 0.034 & 0.039 \\
\hline & Liver & 0.045 & 0.054 & $0.0 \leqslant 2$ & 0.068 & 0.083 \\
\hline & Lungs & 0.045 & 0.054 & 0.054 & 0.065 & -.0ิธ1 \\
\hline & GI Iract & 0.524 & 0.029 & 0.031 & 0.035 & 0.042 \\
\hline
\end{tabular}


Zacle 2.ó.(cont"d.)

\begin{tabular}{|c|c|c|c|c|c|c|}
\hline \multirow[b]{2}{*}{$\begin{array}{l}\text { Radio- } \\
\text { nuclide }\end{array}$} & \multirow[b]{2}{*}{ Body jrzan } & \multirow[b]{2}{*}{$0-1$ year } & \multicolumn{3}{|c|}{ Effective Absorkei Ineng (AeV) } & \multirow[b]{2}{*}{$\begin{array}{l}\text { greater } \\
\text { than } \\
15 \text { yєars }\end{array}$} \\
\hline & & & $1-5$ years & $5-10$ years & $10-15$ jears & \\
\hline \multirow{5}{*}{188} & ictal body & 0.85 & 0.85 & 0.87 & 0.89 & 0.93 \\
\hline & Hore & 3.30 & 3.80 & 3.81 & 3.81 & 3.8 \\
\hline & Liver & 0.89 & 0.89 & 0.90 & 0.90 & 0.92 \\
\hline & Lungs & 0.89 & 0.89 & 0.90 & 0.90 & $0.9 ?$ \\
\hline & GI Iract & 0.78 & 0.78 & 0.78 & 0.78 & 0.78 \\
\hline \multirow{5}{*}{${ }^{203} \mathrm{HE}$} & Total Body & 0.18 & $0.2^{\circ}$ & 0.21 & 0.22 & 0.24 \\
\hline & Liver & 0.14 & 0.15 & 0.16 & 0.16 & 0.17 \\
\hline & Kidneys & 0.13 & 0.14 & 0.14 & 0.15 & 0.15 \\
\hline & Lurges & 0.14 & 0.15 & 0.15 & 0.16 & 0.17 \\
\hline & GI Tract & 0.33 & 0.12 & 0.13 & 0.14 & 0.14 \\
\hline
\end{tabular}




\subsubsection{Effective Half-Time}

Effective half-time is another of the age-dependent parameters in the INREM code for which descriptive data are scarce. Agecependent values were used for ${ }^{3} H^{2.11}$ and ${ }^{131_{I}}{ }^{2.12}$ (see Table 2.8), and standara-man values were applied to all age grougs for other radionuslides.: 2.7 The application of stardard man vaiues to younger age groups is probably conservative in most, if not all, cases. At least a slight increase in effective half-time as the individual ages would be anticipated for most radionucildes, because the basal metabolic rate of man decreases yith increasing age. 2.13 Increases in effective half-times accompanying increases in age of the individual have been observed for several radionuclides $\left({ }_{H}\right.$ and ${ }^{13 I_{I}}$ are examples, see Tabl: 2.7 :

\subsubsection{Daily Radionuclide Intake}

Dafly radionuclide intake informaticn was determined by BCL with the aid of miltirompartmental models simulating the environsentel transfer of radionuclides in stuty areas of Panama and Colombia. 2.14 The kinds and amounts of food item consumed were determined by an extensive census of the indigenous popuiations. $2.5,2.6$

\subsection{Assumptions fisr Computing Bxternal Bete Dose to the Skin}

Most assumptions concerning the potential external exposure of indigenous populations to bete emitters are nore temous than those underlying the hypothetical exposures to ama enitters. If indeed, only the expected exposure situstions arz encountered (i.e., reentry to the exclusion area sometime folloring the last detsonation), then the external exposure to bete emitters would projebly 
Table 2.7. Variations in he Fraction of Iazested 54 ard ard $13 /$ Reachlog the Refererice Drgans as a Fuxtion of Age

\begin{tabular}{|c|c|c|c|c|c|c|}
\hline \multirow[b]{2}{*}{$\begin{array}{l}\text { Padio- } \\
\text { Huclide }\end{array}$} & \multirow[b]{2}{*}{$\begin{array}{c}\text { Reference } \\
\text { Osien }\end{array}$} & \multicolumn{5}{|c|}{$\begin{array}{l}\text { Frection of Inerated Radionctivity Reachine the } \\
\text { Reference Orrar: }\end{array}$} \\
\hline & & D-1 year & $1-5$ years & $5-10$ years & $10-15$ years & $\begin{array}{l}\text { oreeter } \\
\text { than } \\
15 \text { years }\end{array}$ \\
\hline \multirow[t]{3}{*}{${ }^{89} \mathrm{Sr}^{*}$} & Total Body & 0.20 & 0.10 & 0.13 & 0.4 & 0.3 \\
\hline & Bone & 0.14 & 0.07 & 0.09 & 0.28 & 0.17 \\
\hline & Tctal Body & 1.0 & 1.0 & 1.0 & 1.0 & 1.0 \\
\hline${ }^{131} 1^{6}$ & Thrrold & 0.3 & 0.3 & 0.3 & 0.3 & 0.3 \\
\hline
\end{tabular}

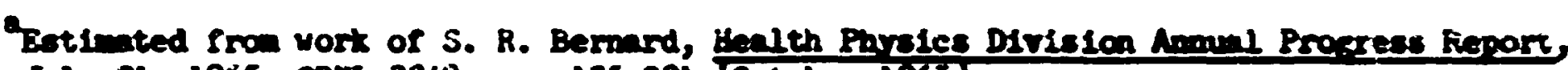
July 31, 1965, 0Rm-3849, P. 195-201 TOetcber 1965).

Federel Radlation Councll, Beckeround Heterlal for the Developunt of Rediation

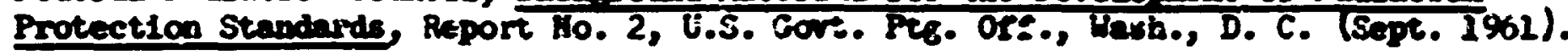

Table 2.8 Vurlations in Erfective half-Tine (dare) of Iritiu and 231 as a Function of Agt

\begin{tabular}{|c|c|c|c|c|c|c|}
\hline \multirow[b]{2}{*}{$\begin{array}{l}\text { Radion } \\
\text { Aucilde }\end{array}$} & \multirow[b]{2}{*}{$\begin{array}{c}\text { Reference } \\
\text { Orgen }\end{array}$} & \multicolumn{5}{|c|}{ Bffective lale-tine (dave) } \\
\hline & & 0.1 yer & 1.5 years & $5 .-10$ yesrs & 10-15 years & $\begin{array}{l}\text { greater } \\
\text { than } \\
15 \text { years }\end{array}$ \\
\hline \multirow[t]{2}{*}{$3 \mathrm{H}^{\mathrm{a}}$} & Intal Body & 3.2 & 4.4 & 4.9 & 6.3 & 9.5 \\
\hline & Total Eody & 4.0 & 5.0 & 6.0 & 6.5 & 7.0 \\
\hline${ }^{131} I^{b}$ & Thyroid & 4.0 & 5.0 & 6.0 & 6.5 & 7.0 \\
\hline
\end{tabular}

A. S. Rolwer and S. V. Kaye, fre Dependent Kodels for Eténetelng Incernal Dose

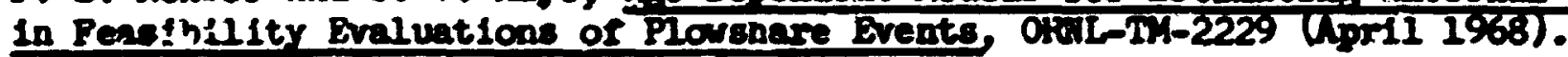

by. J. Cock and H. S. Snyder, Health Physics D1Y18lon Amual Prop. Pieport, July 31, 1965, ORHL-3849, pp. 190-93 (October 1965). 
be negifibil:. This conclusion is gossfole because i) the deposition of beta enittiers directly on the skin of humans is not expected, and 2) beta eaftiers deposited on the landscape probably will have Infiltrated at least the top soll layers due to normal weathering. Even a sall amount of radicnuclide infiltration into soil and litter yould effectively shield this beta emitters, while having but a negirgible erfect on gama emitters.

Generally, it appears thet only the excosure to fresh fallout is inportant for beta skin-dose considerations. Externai exposure to beta enitiers might divelop in the unlikely event that a "cloud" leposits fresh fallout over an inhabited area (1.e., outside the exclusion area). It was primarily with this possibility in mind that potertial bets doses to the skin were computed. Because of rapid weathering effects in the tropical enviroment, the time during which externel exprsure to beta radistion might be important is probably short. Nlso, radioactivity deposited on skin is not likely to yoln there very lone--prohably less than one week.

Dose to the skin from bete emitters yas assessed for radionuclides deposited on the land surface and on the surface of human skin. The germinal or basal layer of the epldermis is usualiy regarded as the most radiosensitive layer of tio sicin. 2.15 Over most parts of the body, the besal. layer 18 approximately $0.1 \mathrm{~mm}$ below the surface, but on the palms of the hands and feet the depth of the basal layer $\$ .8$ approximately $0.6 \mathrm{~mm} .^{2.16}$ Albino Cuna Indians of eastern Panama develop actinic keratoses by the age of three. 2.3 Thus, there is thickening of the skin in areas exposed to sunlight; these same areas would probably be affected by beta enftters. The 
increased depth of the basal layer due to actinic keratoses may vary considerably depending on the severity of the affliction. A jepth of I win was chosen arbitrarily to represent the depth of the critical tissue (basal layer) In the slyin of albino Cuna Indians. These albiinus probatiy are the criticai group for this mode of exposure (if all popuistions are assumed to be equally exposed), because their skin is already in an injured state. This conclusion seems reasonakle despite the slight increase in shielding of the basal layer due to thickening of the corneum. Whitton 2.15 has stated thet,-.- "wounded skin is probably more susceptible to radiation damage than normal skin, but it is impossible to make any quantitative estimation of the degree of susceptibility."

\subsection{Specia? Radiological Protection Considerations}

Radiation dose estinares must be in a form suitable for comparison with the appropriate rajiation safety criteria. The radiation safety criteria suggested for this study are given in terms of dose equivalent rates (rem/year) and total dose equivalents (rem/30 years, rem/70 years) for total body and various parts thereor. ${ }^{2.17}$ Dose equivalent rate and total dose equivalents for any part of the body are the sum of the dose equivalents contributed by both external and internal sources.

\subsubsection{Simultaneous Interns]. Excosure of Multiple Organs}

Estimation of total internal radiation dose to a given organ for the projected canal exposure situation requires the addition of dose contributions from many radionuclides. The "critical organ" concept of the ICRP is the basis for this approsch; the critical organ being defined as that organ whose danage by radiation resulte in the greatest 
damage to the individual or his descendants. 2.18 Dose estimates for nine body organs were obtained with the INREM code to facilitate the assessment of hypothetical exposure situations in terms of the appropriate radiation safety guides.

Addition of doses to different organs presents another probleri. The ICRP states: "Exposure to radioactive materials in the environment may entail significant exposures of several organs. Under such conditions the situation is somewhat comparable to that of irradiation of the whole body. The additional risk when several organs are involved needs to be recognized, although our present knorledge does not permit precise evaluation. ${ }^{2} .18$

The additivity of doses to reference orgrns requires the assumption that exposures to different parts of the body are not synergistic, i.e., that the radiation response of one part is uct affected by the radiation exposure received by another part. The ICRP suggests that an exposure should be considered as excessive if three or more organs are exposed at more than one-half their respective Maximum Permissible Dases. 2.18

\subsubsection{Additivity of Internal and External Dose}

Potential total dose to an individual from specified sources is estimated by summing the doses from all external and internal exposures. Keep in mind that all modes of exposure were not evaluated in this study, and that estimates of potential total dose in this report Include only dose contributions from external exposure above the contaminated land surface and from intermal exposure via ingestion of contaminated foca and beverages. 
Procedures for this addition in the case of occupational exposures have heen suzgested by the ICRP. One suggestion is found in ICRP Publ. $6: 2.19$ "The Commission has considered the difficulty of making proper allowance for the addition of doses from penetrating external exposure and from internal exposure in the case of long-lived boneseeking isotopes, in view of the use for them of che "n" factor. For these radionuclides the Commission recommends that (i) if the estimated body-burden is less than one-half of the maximm permissible, no consequential restriction of externai raaiation exposure need be appiled; (ii) if the estimated body-burden is greater than one-half but less than the maximum permissible, the total body exposure to penetrating external radiation shall be limited to not more than 1.5 rems in any year; and if $A$ years is the age of the individual when the body-burden was first found tc exceed one-half of the maximun permissible, then the total accumulated dose from such future exposure beyond age A shall not exceed 1.5 (N-A) rems where $N$ is the current age of tine individual; if, however, at age B the bodyburden is found to have dropped to less than one-half the maximum permissible value, the accumulated dose from future external total body exposure beycnd age B skall not exceed 5 (N-B) rems; (iii) if the estimated body-burden equals or exceeds the maximum permiusible, no occupational exposure to penetrating external radiation is permissible." Another suggestion, this one not specifically related to long-lived bone-seeking radjonuclides and occupational workers, is found in ICRP Publ. 9: 2.18 "If external expcsure of the whole body has resulted in an excese of one-half of the Maximm Permissible Dose to the gonads or to the red bone-marrow, no two or more organs stall be exposed at more than one-half their respective Maximm Permissible Doses." 
A more recent publication of the ICRP, feport of the Task Group on Spatia: Distribution of Radiation Dose, briefly touches upon the additivity problem. 2.20 A point is made of the fact that the present system of a large number of critical organs, most of which carry the same dose limit, is not a scheme based on risk constiderations, and additivity rules are of necessity largely arbitrary. The Task Group, while supporting the above quoted views of the Comission, expressed the opinion that the suggested additivity procedures are sometines applied too strictly.

\subsubsection{Apportioment of Genetic Dose to Casal Bxcavation}

Guidance is given in ICRE Report 1 suggesting that 1.5 rems of the genetic dose limit of 5 rems/30 years should be kept in reserve and not apportioned to any presently recognized exposure applications.2.21 Thus, we are left with 3.5 rems/30 years, or 0.117 rem/year for actual apportionment to all sources except background and medical sources. Further guidance relevant to apportioment is given by the ICRP in Report $9^{2.22}$ as follows: "The Commissicn wishes to point out that it is important to enslire that no single type of population exposure takes up a disproportionat,e share of the total. The way in which this is dcne will depend upon circumstances which may vary from country to country, and will be determined by national, economic and social considerations." A disproporticnate share of the genetic dose limit (or genetically significant dose) for a single type of exposure could conceivably be an aliocation of one-half or more of the total amount to be apportioned (f.e., $0.117 \mathrm{rem} / \mathrm{year}$ ). A maxdmm, one-half ailocation for tine canal construction project would leave approximately 60 mrems/year. Assessments of genctically significant dose in this 
report are based on the rull (5 rems/30 years) allocation. It seens prudent to these authors to assume that any nation's system of genetic dose apportionent, taking various economic and sociopolitical factors Into account, would follow the guldance of th: ICRP and result in reduced allocations of dose for an muclear excavation project, the present one included. 
References for Chapter 2.0

2.1 C. E. Keeler, J. Heredity 55, 115 (1964).

2.2 C. E. Keeler, The MSH Bulletin of Current Research 2,

$8(19+3)$

2.3 C. E. Keeler, "Albinism, Xerodermo Pignentosum, and Skin," p. 349 in Dational Canser Institute Yonograph No. 10, Proceedings of the Conference on Biology of Cutaneous Cancer, Philadelphis, Penn., April 6-11, 1962.

2.4 R. T. de Arauz, Demographic Characteristics of Huan Groums Inhabiting the Bastern Region of the Republic of Panan, (Feb. 23, 1968).

2.5 R. T. de Arauz, Bio. Sc1. 19, 331 (1969).

2.6 E. H. MeBryde : dd A. 5. Costales, B10. Sc1. 19, 432 (2969).

2.7 International Comission on Radiological Protection, Recomendations of the International Comenission on Radiological Protection (Report of Canittee 2 an Permissible Dose for Internel Radiation), ICRP Publ. 2, Pergancon Press, London (1959).

2.8 H. Skelton, Arch. of Int. Med. 40, 140 (1927).

2.9 Interdepartmental Counittee on Nutritios for llational Defense, Colombia Hulrition Survey, J.S. Govt. Ptg. Off., Weshington,D.C. (December 1961).

2.10 W. S. Snyder, Personal Comminication.

2.11 P. S. Robwer and S. V. Kaye, Age-Dependent Yodels for Estimating Internal Dose in Feasibility Evaluattuns of Plorshare EventB, ORIL-TY-2229 (Apr11 1968). 
E.12 D. F. Bunch, Controlled Bovironentel Radiolodine Tests Progress Report llumber 2, ID0-12053 (August 1965).

2.13 P. Bari (Ed.), Eedical Progiology, 11th Ed., f. 378, The C. V. Mosby Cospanf, St. Iouls (1961).

2.14 S. G. Bloom, A. A. Levin, W. B. Martin, and G. E. Raines, Mathematical Methods for Braluating the Transport and Accullat fon of Radionuclides, Bu-171-030 (Apr11 3, 1970).

2.15 J. T. Witton, Blological Aspects of Skin Irradiation. Part I. Prelininary Investigations, FD/B/H/1351; (April 1969).

2.16 R. F. Rushmer, K. J. K. Buettiner, J. M. Short, and G. F. Oaland, Sclence 154,343 (1966).

2.17 K. E. Cowser, S. V. Kave, F. S. Robre:r, W. S. Swyder, and E. G. Struxmes8, Dose-Estimation Studies Related to Proposed Constiuction of an Atlantic-Paciflc Interoceanic Canal with Maclear Bxplosives:

Phase I, ORII-4101 (Yarch 1967).

2.18 International Cownission m Radiological Protection, Recamendations of the International Conission on Radiolngical Protection (Adopted September 17, 1965), ICRP Publ. 9, Pergamon Press, Lordon (1965).

2.19 International Combission on Radiological Protection, Recomendations of the Internationel Comission on Radiological Protection (sis Amended 1959 and Revised 1362), ICRP Publ. 6, Pergamon Press, London (1964).

2.20 International Comission on Radiological Protection, Radiosensitivity and Spatial Distribution of Dose (Reports Prepared by Two Task Groups of Comnitten 1 of the International Counission on Radioiogical Protection), ICRP Pub1. 14, Pergamon Press, London (1969). 
2.21 Internatioral Comission on Radiological Protection, Recomendations of tre Interrational Commission on Radiological

Protection (Adogted September 9, 1958), ICRP Publ. 1, p. 15, addendum to para. (65), Pergamon Press, London (1959).

乏..2 Interiaticual Comission on Radiological Protection, Recamendations of the International Comission on Radiological

Protection (Adonted Sentenber 17, 1965), ICRP Publ. 9, p. 15, para. (87), Pergamon Fress: London (1966). 


\subsection{DOSE ESTIMATION MODELN}

Although the EXRFM and INREM codes compute doses fram several modes of exposure, only external exposure to the contaminated land surface (with model adaptations for calculating doses from beta emitters deposited on skin) and internal exposures resulting from intakes of contamirated food and teverages are considered here.

\subsection{External Exposure to a Contamizated Landscape}

The source is assumed to be a thin, infinite, smooth plane uniformly contaminated; air is the only shielding medium. The only rate process assumed to affect the concentration of fallout per unit area following deposition is radicactive decay; no loss due to environmental factors (e.g., runoff and erosion) is considered.

Crocker and Connors ${ }^{3.1}$ was the primary reference for radionuclide cnergies, abundances, and radioactive half-lives of fissicn products, whereas Crocker and Wong ${ }^{3 . \hat{c}}$ provided much of the data on induced activities. When the required data could not be found in these two references, the Table of Isotopes by Ledere: et al. ${ }^{3.3}$ was used. In some cases, when data in Crocker and Connors or Crocker and Wong differed greatly from Lederer et al., the Lederer source was us $€$ d because it is a more recent publication. Appendix $I$ is a computer listing from the EXREM code of radionuclide index iuentification number, atomic number, name, decay constant, and the total number of beta particles and gamma photons emitted by each of 170 radionuclides for which external doses were estimated. 
Fission product decaj chains and braniring ratios used in the SXXRP code were taken from Fleming; 3.4 however, nc nuclide with a radioactive haif-life of 20 minutes or less was included in the compilation if the nuclide was first in a decay chain. Lederer ${ }^{3 \cdot 3}$ was the source for the few nonfissicn-product nuclides $\left(188_{\mathrm{W}},{ }^{202} \mathrm{~Pb}, 210_{\mathrm{Pb}}\right.$, $237_{\mathrm{U}}$, and ${ }^{\left.\hat{\imath} I_{\mathrm{P}} \mathrm{P}\right)}$ decaying to radioactive daughters of potential importance.

Tt:e gamma dose mudel in EXREM uses the linear absorption coefficient $\left(\|-\sigma_{s}\right)$ to account for the absorption of rediation in air. A table of $\mu-\sigma_{s}$ (derived from multiplying the mass absorption coefficient by the density of air) is stored in the code and necessary values are obtained by Lagrangian interpolation. The National Bureau of Standards Handbook No. $1003^{3.5}$ was the source of mass absorption coefficients. By using $\mu-\sigma_{s}$ to describe energy absorption in air, the original photon energy lost from the site of interaction by Compton scattering was excluded from consideration in the calculations. This will tend to produce a conservative estimate of dose.

\subsubsection{Dose Rate}

The dose rate at time $t$, including the contribution from radiunuclide decay chains, is denoted by

$$
R_{i q \ell}(t)=C_{i \ell}(t) D_{i q}
$$

where $i=$ radionuclide index,

$q=$ radiation index ( $\beta$ for beta radiation; $\gamma$ for garma radiation),

$\ell=$ location index,

$c_{i l}(t)=\underset{l^{t h}}{\text { areal concentration }\left(\mu \mathrm{Cl} / \mathrm{cm}^{2}\right)}$ of the $i^{\text {th }}$ radionuclide at the 


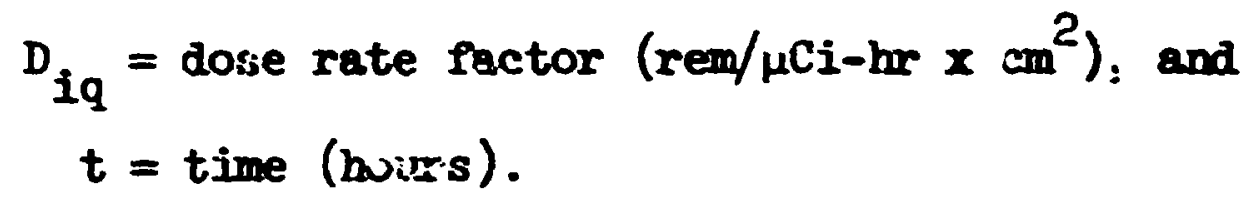

The basic dose rate factor for gamma radiation $(q=y)$ at the surface of a budy immersed in air was adapted from Morgan and Bnerson 3.6 and is written

$$
D_{i \gamma}=827 \text { B } \sum_{n=1}^{N i} \epsilon_{i n} f_{i n} \mu\left(\epsilon_{i n}\right) E_{1}\left[\mu\left(\epsilon_{i n}\right) x\right](r e m / h r),
$$

where

$D_{i y}=$ dose equivalent rate $(\mathrm{rem} / \mathrm{hr})$ from gamiza photons at a height of $x \mathrm{~cm}$ above a landsurface contaminated with $1 \mu \mathrm{Ci}$ of radionuclide $i$ per $\mathrm{cm}^{2}$,

B $=1.14$ = backscatter correction for a body immersed in air, $\tau_{0}=$ photon index,

$Y_{i}=$ number of gamma photons emitted by the $i^{\text {th }}$ radionuclide, $\epsilon_{\text {in }}=$ energy (MeV) of the $n^{\text {th }}$ photon emitted by the $i^{\text {th }}$ radionuclide, $\mathbf{f}_{\text {in }}=$ abundance (dimensionless) of the $n^{\text {th }}$ photon emitted by the $i^{\text {th }}$ radionuciide,

$\mu\left(\epsilon_{\text {in }}\right)=\mu-c_{\mathrm{g}}$ in the usual notation = Iinear absorption coefficient $\left(\mathrm{cm}^{-1}\right)$ for the $n^{\text {th }}$ photon of the $i^{\text {th }}$ radionuclide, and

$E_{1}\left[\mu\left(\epsilon_{\text {in }}\right) x\right]=E$-function of the first orier for the argument

$$
\left[\mu\left(\epsilon_{\text {in }}\right) x\right] \text {. }
$$

When the radiation source is from beta emissions, the dose rate factor is computed from the following expression 3.7

$$
R_{1 \beta}=1.07 \sum_{n=1}^{N N_{B i}}\left\{v \alpha(F[C, v, a(x)]+\exp [1-v a(x)]) f_{\text {in }{ }_{\text {In }}} \bar{E}_{1}\right.
$$


where $R_{j \beta}$ = dose equivalent rate $(\mathrm{rem} / \mathrm{hr}$ ) at a height of $x$ an above a landsurface conteminaied with $1 \mu \mathrm{Ci} / \mathrm{cm}^{2}$ of bete-emitting radionuclide i,

n = particle index,

$N_{B i}=$ number of beta particles emitted by the $i^{\text {th }}$ radionuclide, $f_{\text {in }}=$ abundance (dimensionless) of the $n^{\text {th }}$ beta particle emitted by the $i^{\text {th }}$ radionuclide,

$\overline{\mathrm{E}}_{\text {in }}=$ average energy $(\mathrm{MeV})$ of the $\mathrm{n}^{\text {th }}$ beta particle omitted by the $i^{\text {th }}$ radionuclide,

$C=\left\{\begin{array}{l}3.0, \quad E_{\text {in }}<0.17 \\ 2.0,0.17 \leq E_{\text {in }}<0.5 \\ 1.5,0.5 \leq E_{\text {in }}<1.5 \\ 1.0,1.5 \leq E_{\text {in }}\end{array}\right.$

$F_{\text {in }}=$ maximum erergy $(\mathrm{MeV})$ of the $\mathrm{n}^{\text {th }}$ bets parificle emitted by the $i^{\text {th }}$ radionuclide,

$\alpha=\left\{\begin{array}{l}0.190, \quad E_{\text {in }}<0.17 \\ 0.260,0.17 \leq E_{\text {in }}<0.5 \\ 0.297,0.5 \leq E_{\text {in }}<1.5 \\ 0.333,1.5 \leq E_{\text {in }},\end{array}\right.$

$v=\left\{\begin{array}{l}\frac{(18.6)}{\left(E_{B \text { in }}-0.036\right)^{1.37}} \text { if the radionuclide is not }{ }^{90} \mathrm{Sr}, \\ \frac{(0.83)(18.6)}{\left(E_{B \text { in }}-0.036\right)^{1.37}} \text { if the radionuclide i.s } \\ 90 \mathrm{Sr},\end{array}\right.$

$F[C, v, a(x)]=\left\{\begin{array}{l}c\left\{1+\ln \left[\frac{C}{v a(x)}\right]-\exp \left[1-\left(\frac{\nu a(x)}{C}\right)\right]\right\} \text { if } v a(x)<C, \\ 0 \text { if } v a(x) \geq C, \text { and }\end{array}\right.$ 
$a(x)=$ distance from the contaminated surface multipl.ied by the density of air $\left(\mathrm{g} / \mathrm{cm}^{2}\right)$.

The areal concentration, $C_{i f}(t)$, is derived from the nuclide chain equations for radioactive decay. For a single detonation, an explicit expression for the areal concentration at time $t$ of the $i^{\text {th }}$ radionuclide in a pathray for radioactive decay is aenoted by

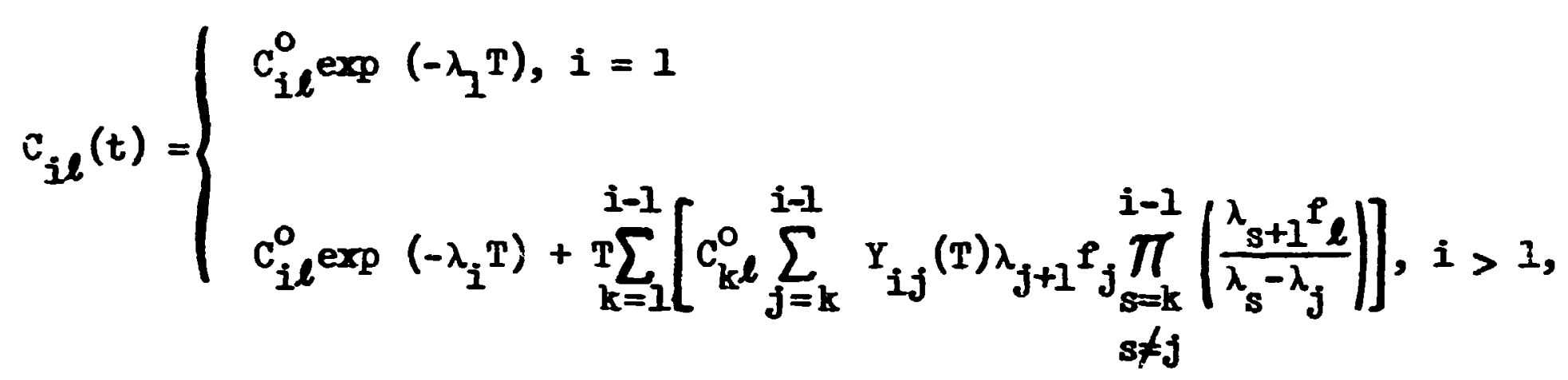

where

$$
\begin{aligned}
& T=t-t_{0},
\end{aligned}
$$

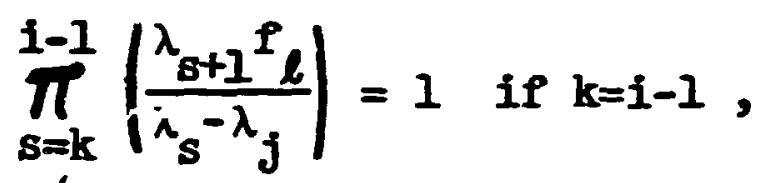

$$
\begin{aligned}
& s \neq j \\
& Y_{i j}(T)=\left\{\frac{\exp \left(-\lambda_{j} T\right)-\exp \left(-\lambda_{i} T\right)}{\left(\lambda_{1}-\lambda_{j}\right) T}\right\}, \\
& \lambda_{i}=\text { radiclogical decay constant (hours }{ }^{-1} \text { ) of the } i^{\text {th }} \text { radionuclide, } \\
& f_{i}=\text { fraction of nuclei of the } i^{\text {th }} \text { radionuclide which decay to the } \\
& i+1^{\text {st }} \text { nuclide in the nathway, } \\
& t_{0}=\text { time (hours) of envirormental release, } \\
& c_{i l}^{0}=g_{i l} Y_{i} \text {, } \\
& g_{1 \ell}=\text { location correction factor for the } 1^{\text {th }} \text { radionuclide at the } \\
& \ell^{\text {th }} \text { location, and } \\
& Y_{i}=\text { yield }(\mu \mathrm{Ci}) \text { released to the environent from the detonation. }
\end{aligned}
$$


To determine the areal conrentration of a radionuclide in a chain containing more than one pathway for radioactive decay, contributions for the nuclide are summed for each pathway wich is unique up to that radionuclide. 3.8

The areal concentration, ${ }_{M} C_{i l}{ }^{(t)}$, at time $t$ of the $i^{\text {th }}$ radionuclide resulting from $M$ detonations is obtained by evaluating E.q. (3.4) where

$$
c_{i l}^{o}={ }_{M-1} C_{i l}\left(\tau_{M}\right)+g_{i \ell M} Y_{i M} \text {, }
$$

and where

$$
\begin{aligned}
& T_{M}=\text { time (hours) of the } \mathrm{M}^{\mathrm{t}} \mathrm{h} \text { detonation, } \\
& T= \pm-T, \\
& g_{i l M}=g_{i l} \text { for the } M^{\text {th }} \text { detonation, } \\
& Y_{i M}=Y_{i} \text { for the } M^{\text {th }} \text { detonation, and } \\
& M-I^{C}{ }_{i l}{ }^{\left(T_{M}\right)}=\text { the areal concentration at time } \tau_{M} \text { of the } i^{\text {th }} \text { radio- }
\end{aligned}
$$

Although it is stated at the beginning of this chapter that the dose models apply to a plane source when the absorbing medium is air, these molels also may be used to estimate beta dose rate (and cumulative beta dose) when the radioactire source is deposited on curved body surfaces provided the radius of curvature is larger than the raximum p-particle range. 3.9 inis condition is met for fallout radionuclides deposited directly on liost of man's skin sirface. The leve? of contamination $\left({ } \mathrm{Cl} / \mathrm{cm}^{2}\right)$ is assumed to be the same for skin and land surface. In this situation, the subject would be standing in the open (1.e., out from underneath a thatched ros? or the forest canopy) while fallout is being deposited, and the exposer portions of his body would be covered by the same material ano radioactivity level as was deposited 
on the land at that location. The values ised for $a(x)$ in Eq. (3.3), the distance from the contaminated surface multiplied by the density of air, were adjusted to include $100 \mathrm{~cm}$ of air $+0.1 \mathrm{~cm}$ of skin for exposure above the land surface and only $0.1 \mathrm{~cm}$ of skin for deposition of radioactivity on the skin. In preparing imput data for the EXREM code, $0.1 \mathrm{~cm}$ of skin was considered equal to $83 \mathrm{~cm}$ of air in terms of the shielding of beta particles. The range of beta particles in a medium is essentially independent of the type of material and may be expressed as the thickness times the density $\left(\mathrm{mg} / \mathrm{cm}^{2}\right)$.

\subsubsection{Cumulative Dose}

The estimate of cumulative external dose equivalents (rem), or total external dose, for exposure beginning at $t_{1}$ and ending at $t_{2}$ is given by

$$
\operatorname{TD}_{\text {iql }}\left(t_{1}, t_{2}\right)=R_{i q l} \int_{t_{1}}^{t_{2}} c_{i l}(t) d t \text { (rem), }
$$

where the terms are defined as above.

\subsection{Internal Exposure from Ingestion of Food and Drink}

The dose models used in INREM are presented here in their final form, and the reader is referred to previous publications for more detail concerning these internal dose models. $3.10,3.11$ Dose equivalents (rem) resulting from the ingestion of radioactivity programmed as continuous or intermittent intakes were computed for various body organs. The parameters in these dose models change as a function of age of the Individuel exposed during the time period covered by the dose integration. 


\subsection{All Organs Except the G.I. Tract}

The model progranmed for all organs except the G.I. tract is written

$$
\begin{aligned}
D_{\text {in }}\left(t_{1}, t_{2}, t_{b}\right) & =51 \int_{t_{1}}^{t_{2}} I_{i}\left[\left(t-t_{b}\right), t\right] f_{i n}\left(t-t_{b}\right)\left\{\int_{t}^{t_{2}} \frac{\epsilon_{i n}\left(s-t_{b}\right)}{m_{n}\left(s-t_{b}\right)}\right. \\
& \left.\exp \left[-\int_{t-t_{b}}^{s-t_{b}} \lambda_{\text {in }}(\gamma) d \gamma\right] d s\right\} d t \quad(r e m),
\end{aligned}
$$

where

$$
\begin{aligned}
& D_{\text {in }}\left(t_{1}, t_{2}, t_{b}\right)=\text { Cumulative dose equivalent (rem) received during } \\
& \text { the time interval } t_{1} \text { to } t_{2} \text { from the } i^{\text {th }} \text { radionuclide } \\
& \text { in the } n^{\text {th }} \text { organ resulting from intake during this } \\
& \text { time interval by an individual born at } t_{b} \text {, } \\
& t_{1}=\text { time (days) of initial intake relative to time of reference } \\
& \text { detonation, } \\
& t_{2}=\text { time (days) at end of period of interest relative to time of } \\
& \text { reference detonation, } \\
& t_{b}=\text { time (days) of birth relative to time of reference detonation, } \\
& t=\text { time (days) after reference detonation, } \\
& s=\text { time after intake relative to time of reference detcnation, } \\
& I_{i}(t)=\text { intake }(\mu \mathrm{Ci} / \mathrm{day}) \text { of } i^{\text {th }} \text { radionuclide at } t \text {, } \\
& m_{n}(t)=\operatorname{mass}(g) \text { of the } n^{t h} \text { organ at } t \text {, } \\
& f_{\text {in }}(t)=\text { fractional absorption (aimensioniess) of the } i^{\text {th }} \text { radinnuclide } \\
& \epsilon_{\text {in }}(t)=\text { effective absorbed energy }(\mathrm{MeV}) \text { of the } i^{\text {th }} \text { radionuclide in } \\
& \text { the } n^{\text {th }} \text { organ at } t \text {, and }
\end{aligned}
$$


$\lambda_{\text {in }}(t)=$ effective elimination constant $\left(\right.$ days $\left.{ }^{-1}\right)$ of the $i^{\text {th }}$ radionuclide in the $n^{\text {th }}$ orgen for age $r$ at $t$.

This model is based on the assumption that radionuclides are taken into the body at the rate of $I \mu C i / d a y$ and that elimination from the reference organ is following a single exponential function (except for ${ }^{90} \mathrm{Sr}$, in which case a three exponential retention function is used).

\subsubsection{GI Tract}

Th a model for estimating dose to the GI tract relates intake to dose received from intake at the $(\mathrm{MPC})_{a}$ or (MPC) $w^{\cdot}$ An advantage of this approach is that it utilizes the MPC for the critical segment of the GI tract, which already has built into it the time required for the intake to reach the critical segment, and the time required for emptying tine segment. The model programmed for the G.I. Tract is written

$$
\begin{array}{r}
D_{i \alpha}\left(t_{1}, t_{2}, t_{b}\right)=\frac{0.3 / 7}{A_{n}(M P C)} \int_{i \alpha}^{t_{2}} I_{i}\left(t-t_{b}, t\right) P_{k}\left(t-t_{b}\right) Q_{i \alpha}\left(t-t_{b}\right) R_{i \alpha}\left(t-t_{b}\right) d t \\
\text { (rem), (3.7) }
\end{array}
$$

where

$$
\begin{aligned}
D_{i \alpha}\left(t_{1}, t_{2}, t_{b}\right)= & \text { Cumulative dose equivalent (rem) received by the } \\
& \text { critical segment of the } G I \text { tract during the time } \\
& \text { interval } t_{1} \text { to } t_{2} \text { from the } i^{\text {th }} \text { radionuclide in } \\
& \text { form } \alpha(\alpha=1 \text { for soluble, } \alpha=2 \text { for insoluble) } \\
& \text { resulting from intake during this time interval } \\
& \text { by an individual born at } t_{b}, \\
t_{1}= & \text { time (days) of initial intake relative to time of } \\
& \text { reference detonation, }
\end{aligned}
$$


$t_{2}=$ time (days) at end of period of interest relative to time of reference detonation,

$t_{b}=$ time (days) of birth relative to time of reference detonation,

$t=$ time (days) after reference detonation,

$0.3 / 7=$ maximum permissible dose rate $(\mathrm{rem} / \mathrm{day})$ to the critical segment of the GI tract for standard man, $A_{n}=$ intake $\left(\mathrm{cm}^{3} /\right.$ day) of water by standard man ( $n=$ index for standard man),

$(\mathrm{MPC})_{\mathrm{i} \alpha}=$ the maximum permissible concentration $\left(\mu \mathrm{Ci} / \mathrm{cm}^{3}\right)$ of the $i^{\text {th }}$ radionuclide of form $\alpha$ in water, $I_{i}(t)=$ intake $(\mu \mathrm{Ci} /$ day $)$ of $i^{\text {th }}$ radionuclide at $t$, $P_{k}\left(t-t_{b}\right)=m_{n} / m_{l}$, $Q_{i \alpha}\left(t-t_{b}\right)=\epsilon_{i l \alpha} k \epsilon_{i n \alpha}$, $R_{i \alpha}\left(t-t_{h}\right)=f_{i \ell \alpha} / f_{i n \alpha, \text { and where }}$ $\mathrm{m}_{\ell}=$ mass $(\mathrm{g})$ of the critical segment of the GI tract of an individual in the $e^{\text {th }}$ age group, $\epsilon_{i l \alpha}=$ effective absorbed energy (MeV) of the $i^{\text {th }}$ radionuclide of form $\alpha$ in the critical segment of the GI tract of an individual in the $e^{\text {th }}$ age group, and

$f_{i l \alpha}=$ fraction of the intake from ingestion of the $i^{\text {th }}$ radionuclide of form $\alpha$ reaching the critical segment of the GI tract of an individual in the $e^{\text {th }}$ age group. 


\subsection{Genetically Significant Dose}

Genetic dose is considered both at the level of the individual and at the population level because separate radiation safety guides are available for each. 3.12 In the present instance, genetic dose to an individual is determined on the basis of dose estimates computed with EXREM and INR5M, supplemented with additional information to improve the estimation of potential gonadal dose. At the population level, genetically significant dose requires estimation. Genetically significant dose to a population is the dose which, if it were received by each person from conception to the mean age of childvearing, would result in the same genetic burden to the whole population as do the actual doses ree ved by the individuals. ${ }^{3.13}$ Estimates of genetic doses to individuals are used in conjunction with demographic information to estimate genetically significant dose.

The formulation used to estimste genetically significant doses for populations is adapted from the 1958 Report of UNSCEAR. ${ }^{3.13}$ Genetically significant dose is given by

$$
D^{*}=\frac{1}{w N} \sum_{k} a_{k}^{*} N_{k}^{*} w_{k}^{*} \text { (rem), }
$$

where

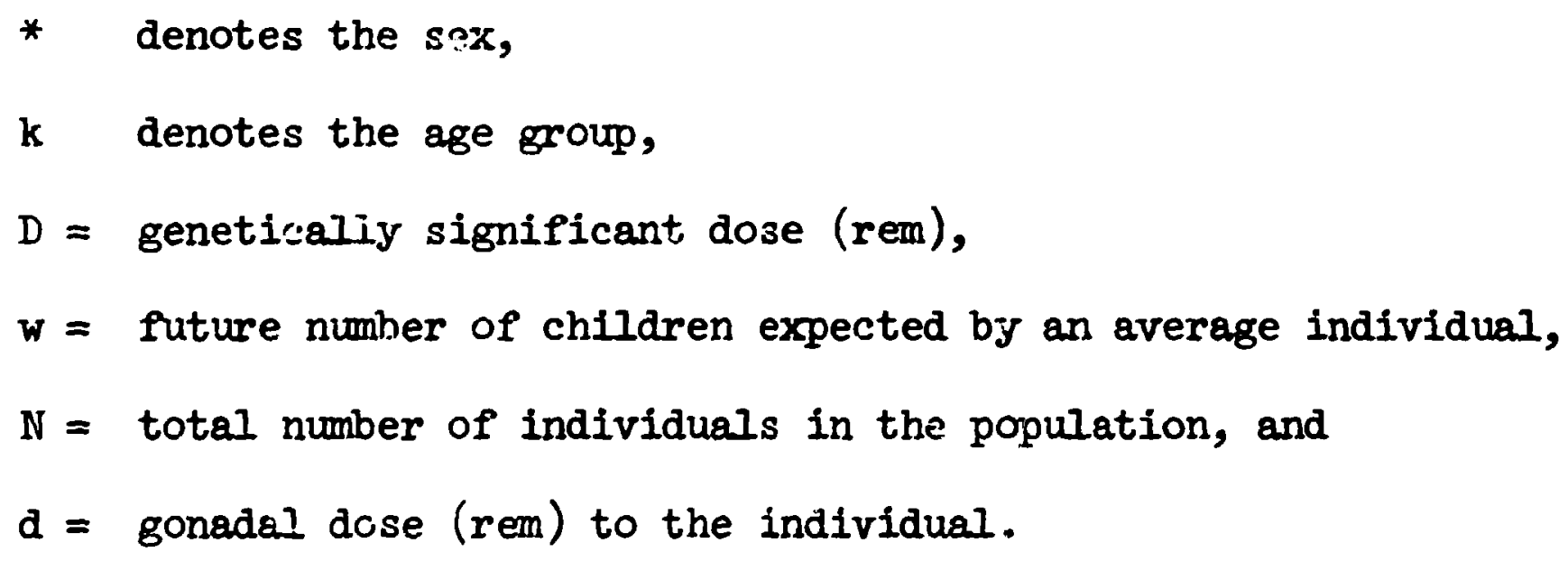


References for Chapter 3.0

3.1 G. R. Crocker and M. A. Conners, Gamma-Emission Data for the Calculation of Exposure Retes from Nuclear Debris, Vol. I. Fission Products, USNRDL-TR-876 (June 10, 1965).

3.2 G. R. Crocker and D. T. Wong, Germa-Emission Data for the Calculation of Exposure Rates from Nuclear Debris. Vol. II. Induced Activities, USNRDL-TR-888 (August 13, 1965).

3.3 C. M. Lederer, J. M. Hollander, and I. Perlman, Table of Isotopes, 6th Ed., John Wiley and Sons, Inc., New York, 1967.

3.4 E. H. Fleming, Jr., Fission Product Decay Chains, Vol. I, UCRL-50243 (March 31, 1967).

3.5 G. R. White, X-Ray Attenuation Coefficients from $10 \mathrm{KeV}$ to $100 \mathrm{MeV}$, NBS landbook 1003 (May 13, 1952).

3.6 K. Z. Morgan and L. C. Emerson, "Dose from External Sources of Radiation," p. 280 in Principles of Radiation Protection, ed. by K. Z. Morzan and J. E. Turner, John Wiley and Sons, Inc., New York, 1967.

3.7 R. Loevinger, E. M. Japha, and G. L. Brownell, "Discrete Railioisotcpe Sources," in Radiation Dosimetry, ed. by G. J. Hine and G. L. Brownell, Academic Press, New York, 1956.

3.8 W. Doyle Turner, The EXRBM II Computer Code for Estimating External Doses to Populations from Construction of a Sea-Level Canul with Nuclear Explosives, CTC-8 (July 21, 1969).

3.9 W. D. Turner, S. V. Kaye, and P. S. Rohwer, EXREM and TNREM Computer Codes for Estimating Radiation Doses to Populations from Construction of a Sea-Level Canal with Nuclear Explosives, K-1752 (September 16, 1968). 
3.10 F. Loevinger, E. M. Jepha, and G. L. Brownell, "Discrete Radioisotcpe Sources," p. 721 in Radiation Losimetry, ed. by G. J. Hine and G. L. Brownell, Academic Press, New York, 1956.

3.1l S. V. Kaye and P. S. Rohwer, "Methods of Estimating Population Exposures from Plowshare Applications," in Proceedings of Symposium on Public Fiealth Aspects of Peaceful Uses of Iruclear Explosives, SWRHL-82, Las Vegas, Nevada, April 7-11, 1969.

3.12 International Commission on Radiologiral Protection, Recommendations of the International Iommission on Radiological Protection (Adopted Sopt. 17, 1965), ICRP Publ. 9, Pergamon Press, London (1966).

3.I3 United Nations, Report of the United Nations Scientific Comittee on the Effects of Atomic Radiation, General Assembly Official Records: Thirteenth Session, Suppl. No. 27 (A/3838), New York (1958). 


\subsection{RADIATIC N DOSE ESTINITES}

All radiation dose estimates were computed with the EXREM and INREM codes on an IBM 360/75 computer. The nuclide-by-nuclide àose sstimates were printed in conventional format but cannot be shawn here because of classification restrictions. Since the estimated total doses are not, classified, these are presented here. Photographs of computer-drawn Cathode Ray Tube (CRT) graphs of dose vs. time consitute the basic format for the display of estimated doses.

Dose estimates in this report are for dry depositian winin the exclusion area; no input data were provided relative to wet deposition or deposition outside the exclusian areas.

\subsection{Potential Exposures for Route 17}

\subsection{External Gamma Dose from Contaminated Land Surface}

Graphs cf potential external gamma dose (mrem) plotted as a function of reentry time are shown in Appendix II, Figs. 1-13, for locations 1-13 (names corresponding to locations 1-13 are indicated in the figure titles). Doses accumulated to 70 years after the initial detonation and the yearly dose rates are plotted on each CRT graph. The first point plotted on each graph represents 30 days after the last detonation (2.65 years after the first detconation), which is the earliest reentry time considered. Tasle 4.1 shows that for each location, at least 98 percent of the 70-year dose is accrued the first 3 years after the initial detonation (approximately one-half year after the last detonation). Consequently, only a small fraction cf the estinated 70-year doses resulting from exposures beginning at the time of the first detonation are shown on the graphs in 
Table 4.1. Partition of Potential External Gamma Dose Between 0-3 Yea:s and 3-70 Years after First Detonation

\begin{tabular}{|c|c|c|c|c|}
\hline \multirow[b]{2}{*}{ Location } & \multicolumn{3}{|c|}{ Cumulative Dose (rem) } & \multirow{2}{*}{$\begin{array}{c}\text { Percent of } 70 \text {-year } \\
\text { Dose Deilivered } \\
\text { by } 3 \text { years }(\%)\end{array}$} \\
\hline & $0-3$ Years & $0-70$ Years & 3-70 Years, & \\
\hline 1. San Miguel & 6.42 & 6.49 & 0.0657 & 98.9 \\
\hline 2. Punta Cocos & 22.8 & 23.1 & 0.252 & 98.7 \\
\hline 3. Garachine & 27.8 & 28.3 & 0.456 & 98.2 \\
\hline 4. Rio Congo & 221. & 224 & 2.98 & 98.7 \\
\hline 5. La PaIma & 255 & 208 & 3.01 & 98.6 \\
\hline 6. Chepigana & 5.08 & 5.21 & 0.129 & 97.5 \\
\hline 7. Junction Rio & & & & \\
\hline $\begin{array}{l}\text { Chucunaque \& } \\
\text { Rio Chiati }\end{array}$ & 6.06 & 6.10 & 0.0388 & 99.3 \\
\hline 8. Uala & 118. & 120 & 1.83 & 98.3 \\
\hline 9. Yantupo & 13.7 & 13.8 & 0.0954 & 99.3 \\
\hline 10. Mulatupo & 121. & 122. & 1.01 & $99 . \hat{z}$ \\
\hline 11. Acla & 34.0 & 34.2 & 0.221 & 99.4 \\
\hline 12. Sabalo & 1.03 & 1.04 & $0.0073 n$ & รั̀.0 \\
\hline 13. Ailikandi & .900 & 0.993 & 0.00720 & 99.3 \\
\hline
\end{tabular}


Appendix II. A great reduction in potential external dose could be reglized if reentry is delayed long enough to allow for the decay of relatively short-lived radionuclides. These graphs show when reentry might be considered, depending on the dose considered acceptable. Reentry is discussed in more detail in Chapter 5.0.

The instantaneous dose rates (rem/hour) as a function of reentry time for all 13 locations are shown in Appendix III, Figs. 1-13. Dose rates below $10^{-6} \mathrm{rem} / \mathrm{hour}$ are plotted at $10^{-6} \mathrm{rem} / \mathrm{hour}$ ( 8.8 mrems/yr) for convenience in the Cril graphical cutput. These graphs indicate the potential dose rates that construction personnel might experience in the exclusion area. The "spikes" in these CRT plots correspond to the time of arrival of fallout from indiriaual detonations. For example, locatinn I receives fallout from 5 detonatinns wilie location $\varepsilon$ receives fallout from 13 detonations. The maximum dose rates (spikes) shown in the CRT plots may not reflect the real maxima because each peak corresponas to $H+24$ (i.e., 24 hours after each detonation). The maximums probably would occur before $H+24$, depending on the size of the explosive, the Afstance to locations of interest, and meteorological phenomena affecting the cloud; hovever, our imput data included only the radioactivity deposIted at ail 13 locations after the firs; $2^{4}$ hours. No data vere provided on levels of contamination for times less than one day after the individual detonations. Furthermore, sume of the radionuclides wth short radioactive half-lives (minutes or hours) eliminated from our input data would tend to increase the peak dose rates. 


\subsubsection{Bxternal Beta Dose to Skin}

Since the radionuclides making up our input dats for each detonation are the same, and only the yield is assumed to differ for various detonations, an assessment of the potential external beta dose can te made by computing the ratio, $\beta$-dose $/ \gamma$-dose, for a single detonation. Bxternal beta dose estimates at a depth of $1 \mathrm{~mm}$ in human skin are presented in Fig. 4.7 as percent of total body ganma dose at $100 \mathrm{~cm}$ for two different levels of activitj. These curves show that the size of the source terin does not affect the magnitude of the percent. No vaines are plotted for the first day after detonation vecause the necessary inpit data were not available.

For the exposures represented in Fig. 4.1, the shapes of the dose curves are similar for the two different source terms; and the curves differ only slightly $(1-4 \%)$ in dependence or the size of the source term as a function of time. All detonations would result in daily betia dose indexes falling within the approximate range indicated for the two source terms in Fig. 4.1. Additional features of this figure for these assumed exposure conditions are: 1) gamma exposure is always higher than beta dose; 2) beta dose to skin is always higher from deposition on skin than from doposition on land; and 3) defly bets doce index is not a constant, but rather a function of post-detonation time.

\subsubsection{Internal Dose from Ingestion}

Estimates of potential internal doses from ingestion of contaminated Ioods and beverages are presented in Appendix IV, Figs. 1-9. The estimated values are totals representing the dose frow 31 radionuclides selected by BCL for detalled consideration. One figure is provided for each reference organ. istimates of 


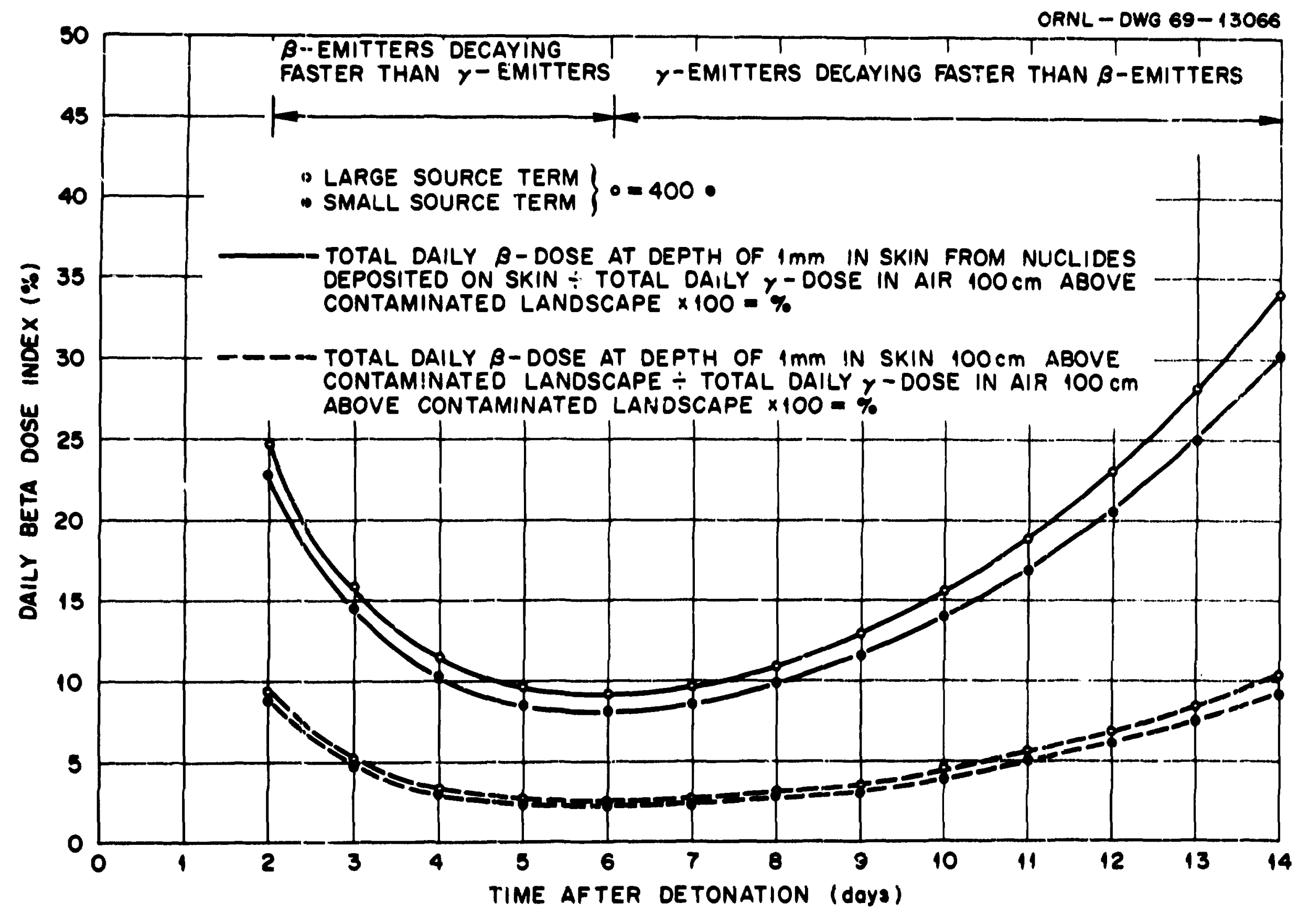

F1g. 4.1. Evaluation of Potent1al Daily Bxternal Beta Dose to Human Skin. 
potential internal dose are presented as a function of reentry time into vatershed 5. Wtershed 5 is only one of several vatersheds vinich together embrace the entire proposed exclusion area; however, watershed 5 has the highest predicted fallout concentrations, and the greatest exposure potential for inhabitants upon reentry into the area. Once indigenous populations reenter watershed 5 following the completion of maclear excavation, each individual is asumed to remain there for the balance of his lifetime. Each figure in Appendix IV contains two curves; one curve represents an estimate of maximum dose comitment (mrem), and the other, an estimate of maximum annual dase rate (mrea/year). Dose comitment is an estimate of the marimum internal dose an individual can receive due to radionuclides taken into the body (i.e., the dose already received filus the dose to be received in his remaining lifetime). The dose estimates presented in Appendix IV are consilered as maximums because they are the highesi potential doses estimated for ingestion. Food intake data used by BCL in estimating daily radionuclide ingestion for various age and ethnic groups (see section 2.5.5) are average volues for individuals within the respective age ranges. In discussing the relationship between average and maximum doses in exposure situations such as this, the FRC suggests use of the arbitrary assumption that the majority of individuals do not vary from the average by a factor greater than three. 4.1 If one adopts that assumption, and even if one has a high degree of confidence in the information used to obtain the dase estimates, one must recognize that some individuals within the age and ethnic group for which highest dose estimates have been obtained could be expected to receive doses wich exceed that dose, by a factor of three. 
Dose estimates were obtained for individuals representing 5 age groups (0-1, 1-5, 5-10, 10- 55 , and greater than 15 years of age) vithin each of four indigenous populations (Cuna Indians, Choco Indians, Negroes, and Colonists). In every case these aose estimates are no greater than those presented in Appendix IV. Briphasis is placed on estimates of maximum dose because, barring great differences in numbers of individuals and/or radiation sensitivities among groups vithin the populations, protection of the group witk the highest potential dose should adequately protect all groups. The range of estimated dose comitments for total body and bone of all age and ethnic groups is illustrat 3 in Figs. $2-8$ of Appendix V. The magnitude of estimated dose commitment and annual dose rate to an organ varies among populaiions and anong age groups within the population. Interpopulation variations shown for a given age group and reference organ are attributable to dietary differences because dajly radiomuclide intake vas the only parameter used to differentiate the four populations. Intrapopulation variation; , on the other hand, reflect the influences of the five parameters used to differentiate age groups. The figures in Appendix $V$ are limited to the first few years following the completion of nuclear excavation because the differences for later reentry times are negligible. Similar variations of estimatel dose cammitments among populations and among age groups within populations were observed for other reference organs. Similar ranges among values vere also observed in the estimates of amnual dose; however, the estimated annual dose rates for most reference organs decline to less than $10 \mathrm{mrems} /$ year soon after the last detonation, and the significance of observed differences beyond that point is questionable. 


\section{L.1.4 Summation of External and Internal Dose Estimates}

Bstimation of total dose for a given radiation exposure situation requires a dose estimate for each mode of potential exposure. In this study, total Jose estimates vere obtained by adding the external dose estimates for location 4 (Rio Congo) to the intermal dose estimates for watershed 5. The external dose estimates for Rio Congo vere used for two reasons: 1) Rio Congo is located in watershed 5, and more important, 2) the initial areal fallout concentration at Rio Congo is approximately equal to the average initial fallout concentration in watershed 5.

Tables 4.2-4.4 demonstrate the addition of potential external and internal doses for three reentry times. Presentation of these data for three reentry times illustrates the relative importance of exposure modes as a function of reentry time. Although external dose was dominant at all post-evacuation times, that dominance increases for later reentry times. One probable explanation for this increasing dominance of extermal dose is the fact that radicactive decay tas the only parameter considered as reducing the external exposure as a function of time. This addition of potential external and internal doses tends to deemphasize age and ethnic group differences because the external dose estimates, which dominate here, were not calculated with models reflecting age and population variations. To illustrate the trend of summed dose throughout the post-excavation period, summed dose estimates for one reference organ (total body) are presented in Fig. 4.2 for reentry times up to 50 years after the first detonation. 
Table 4.2. Summation of Dose Estimates for Nodes of Exposure Conetdered, Watershed 5, Route 17.

Eiposure starting 2.652 years after the first detanation ( 30 days after the last detonation).

\begin{tabular}{|c|c|c|c|c|}
\hline $\begin{array}{l}\text { Body } \\
\text { Organ }\end{array}$ & $\begin{array}{l}\text { Critical } \\
\text { Population }\end{array}$ & $\begin{array}{l}\text { Csitical Age } \\
\text { Group (years) }\end{array}$ & $\begin{array}{l}\text { Estimated Dose (rem) to } \\
\text { Age } 70 \text { years } \\
\text { (Internal + External) }\end{array}$ & $\begin{array}{c}\text { Estimated Maximum Annual Dose Rate } \\
\text { (rem/year) } \\
\text { (Internal + External) }\end{array}$ \\
\hline Total Body & Colonist & $1-5$ & $1.00+4.25=5.25$ & $0.968+1 . .96=2.93$ \\
\hline Bone & Negro & $0-1$ & $5.75+4.25=10.0$ & $5.21+1.96=7.17$ \\
\hline Liver & Colonlst & $1-5$ & $1.27+4.25=5.52$ & $1.17+1.96=3.13$ \\
\hline K1dneys & Colonist & $1-5$ & $4.17+4.25=8.42$ & $3.97+1.96=5.93$ \\
\hline Thyroid & Colonist & $1-5$ & $5.37+4.25=9.62$ & $5.34+1.96=7.30$ \\
\hline Testes & Colonist & $1-5$ & $1.15+4.25=5.40$ & $.1 .12+1.96=3.03$ \\
\hline Ovartes & Colonist & $1-5$ & $1.00+4.25=5.25$ & $0.968+1.96=2.93$ \\
\hline Lungs & Colonist & $1-5$ & $1.00+4.25=5.25$ & $0.968+1.96=2.93$ \\
\hline GI Tract & Colonist & $1-5$ & $1.04+4.25=5.29$ & $. L .01+1.96=2.97$ \\
\hline
\end{tabular}


Table 4.3. Summation of Dose Estimates for Modes of Exposure Considered, Watershed 5 , Route 17. Exposure Starting 5 years after the first detonation.

\begin{tabular}{|c|c|c|c|c|c|c|c|}
\hline $\begin{array}{l}\text { Body } \\
\text { Organ }\end{array}$ & $\begin{array}{l}\text { Critical } \\
\text { Population }\end{array}$ & $\begin{array}{l}\text { Critical rge } \\
\text { Group (years) }\end{array}$ & $\begin{array}{r}\text { Estimated } \\
\text { Age } 7 \\
\text { (Interra: }\end{array}$ & $\begin{array}{l}\text { Dose (rem) to } \\
0 \text { years } \\
1 \text { + External) }\end{array}$ & $\begin{array}{r}\text { Estimated Maximum } \\
\text { (rem/ } \\
\text { (Interual }\end{array}$ & $\begin{array}{l}\text { Annual Dose } \\
\text { (year) } \\
+ \text { External) }\end{array}$ & Rate \\
\hline Total Body & Colonist & $0-1$ & 0.0254 & $+1.72=1 . \therefore 4$ & $0.00: 33$ & $+0.203=$ & 0.205 \\
\hline Bone & Colonist & $0-1$ & 0.332 & $+1.72=2.05$ & 0.0229 & $+0.203=$ & 0.226 \\
\hline Liver & Colonist & $0-1$ & 0.0309 & $+1.72=1.75$ & 0.00252 & $+0.203=$ & 0.206 \\
\hline Kidneys & Negro & $0-1$ & 0.0381 & $+1.72=1.76$ & 0.00402 & $+0.203=$ & $0.20^{\prime} 7$ \\
\hline Thyroid & Colonist & $0-1$ & 0.0255 & $+1.72=1.74$ & 0.00239 & $+0.2 .03=$ & 0.205 \\
\hline Testes & Colonist & $0-1$ & 0.0258 & $+1.72=1.74$ & 0.00245 & $+0.203=$ & 0.205 \\
\hline Ovaries & Colonist & $0-1$ & 0.0254 & $+1.72=1.74$ & 0.00238 & $+0.203=$ & 0.205 \\
\hline Lungs & Colonist & $0-1$ & 0.0254 & $+1.72=1.74$ & 0.00238 & $+0.203=$ & 0.205 \\
\hline GI Tract & Negro & $0-1$ & 0.0760 & $+1.72=1.80$ & 0.0269 & $+0.203=$ & 0.230 \\
\hline
\end{tabular}


Table 4.4. Summation of Dose Estimates for Modes of Exposure Considered, Watershed 5 , Route 17. Exposure starting 30 years after the first detonation.

\begin{tabular}{lll}
\hline $\begin{array}{l}\text { Body } \\
\text { Organ }\end{array}$ & $\begin{array}{c}\text { Estimated Dose (rem) to } \\
\text { Age 70 years } \\
\text { (Internal + External) }\end{array}$ & $\begin{array}{c}\text { Estimated Maximum Annus.1. Dose Rate } \\
\text { (rem/year) } \\
\text { (Internal + External) }\end{array}$ \\
\hline Total Body & $0.0154+0.610=0.625$ & $0.00194+0.0198=0.0217$ \\
Bone & $0.165+0.610=0.775$ & $0.0123+0.0198=0.0321$ \\
Liver & $0.0176+0.610=0.628$ & $0.00193+0.0198=0.0217$ \\
Kidneys & $0.0209+0.610=0.631$ & $0.00200+0.0198=0.0218$ \\
Thyroid & $0.0154+0.610=0.625$ & $0.00194+0.0198=0.0217$ \\
Testes & $0.0161+0.610=0.626$ & $0.001 .96+0.0198=0.0217$ \\
Ovarles & $0.0154+0.610=0.625$ & $0.00194+0.0198=0.0217$ \\
Lungs & $0.0154+0.610=0.625$ & $0.001 .94+0.0198=0.0217$ \\
GI Tract & $0.0345+0.610=0.644$ & $0.00431+0.0198=0.0241$ \\
\hline
\end{tabular}




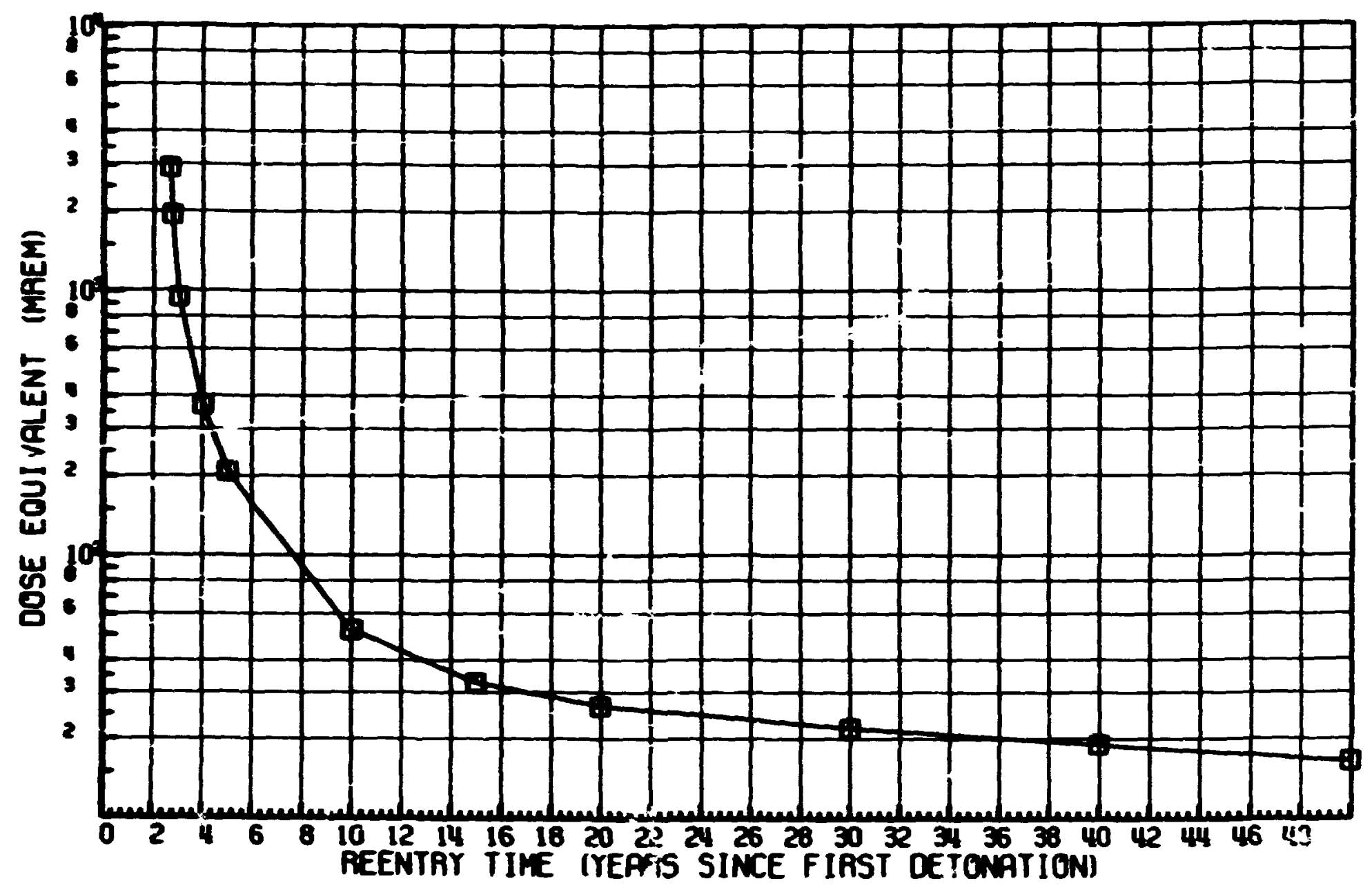

Fig. 4.2. Tota? Estimated Dose to the Total Body for Reentry Times up to 50 Years after the First Detonation, Watershed 5, Route 17. 


\subsection{Potential Exposures for Rouie 25}

\subsection{Internal Dose fram Ingestion}

Estimates of potential internal dose from ingestion of contaminated fouds and beverages are presented in Appendix VI, Figs. 1-9. Due to the marked similarities to the hypothetical exposure situations and dose estimates for Route 17, description of the results for Route 25 will be simplified; the reader may refer back to section 4.1.3. These internal estimates are for watershed 2 , one of several wich together embrace the entire proposed exclusion area for Route 25. Daily radionuclide intake (as a function of diet) is the only internal dose parameter used to differentiate the two routes; the same four ethic groups are assumed to be indigenous to each route. The range of variation in potential dose commitment among all age and ethnic groups is illustrated by the examples for total body and bone in Figs. 1-8 of Appendix VII.

\subsubsection{Summation of External and Internal Dose Estimates}

Infinite gamma exposure contour maps provided by ESSA indicate that the highest contour passing through watershed 2 is $10 \mathrm{~K} / 70$ years for exposures beginning 30 days after the last detonation; therefore, we used $10 \mathrm{rems}$ as an estimate of external gamma dose resulting from 70 years of exposure to contaminated land surface. Time course for the delivery of extermal dose was assumed to be identical with that for Route 17.

The additions of external end internal dose estimates for various reentry times are shown in Tables 4.5-4.7. Again we emphasize that these summed estimated doses do not include all potential expnsure modes. As in the case of Route 17, the doses resulting from external exposure to the contaminated land surface are the dominant ones. 
Table 4.5. Summation of Dose Estimates for Modes of Exposure Considered, Watershed 2, Route 2.5. Bxposure starting 1.570 years after the first detonation ( 30 days after the last detonation).

\begin{tabular}{|c|c|c|c|c|c|c|c|c|c|c|}
\hline \multirow{2}{*}{$\frac{\begin{array}{l}\text { Body } \\
\text { Organ }\end{array}}{\text { Total Body }}$} & \multirow{2}{*}{$\frac{\begin{array}{c}\text { Critical } \\
\text { Population }\end{array}}{\text { Colonist }}$} & \multirow{2}{*}{$\frac{\begin{array}{l}\text { Criticel Age } \\
\text { Group (years) }\end{array}}{1-5}$} & \multicolumn{4}{|c|}{$\begin{array}{l}\text { Estimated Dose (rem) to } \\
\text { Age } 70 \text { years } \\
\text { (Internal + Bxternal) }\end{array}$} & \multicolumn{3}{|c|}{$\begin{array}{c}\text { Estimated Maximum Anzinal Dose } \\
\text { (rem/fear) } \\
\text { (Internai + ixternal) }\end{array}$} & \multirow[t]{2}{*}{ Rate } \\
\hline & & & 0.560 & +10.0 & $=$ & 10.6 & 0.556 & +4.61 & 5.17 & \\
\hline Bone & Choco & $1-5$ & 1.58 & +10.0 & $=$ & 11.6 & 1.41 & +4.61 & $=6.02$ & \\
\hline Liver & Choco & $1-5$ & 0.305 & +10.0 & $=$ & 10.9 & 0.885 & +4.61 & $=5.50$ & \\
\hline Kidanc ys & Choco & $1-5$ & 5.82 & +10.0 & $=$ & 15.8 & 5.74 & +4.61 & $=10.4$ & \\
\hline Thyroid & Colonist & $1-5$ & 0.942 & +10.0 & $=$ & 11.0 & 0.938 & +4.61 & 5.55 & \\
\hline Testes & Colonist & $1-5$ & 0.569 & +10.0 & $=$ & 10.6 & 0.564 & +4.61 & $=5.17$ & \\
\hline Overies & Colonist & $1-5$ & 0.560 & +10.0 & $=$ & 10.6 & 0.556 & +4.61 & $=5.17$ & \\
\hline Lingss & Colonist & $1-5$ & 0.560 & +10.0 & $=$ & 10.6 & 0.556 & +4.61 & $=5.17$ & \\
\hline GI Tract & Choco & $1-5$ & 0.582 & +10.0 & $=$ & 10.6 & 0.563 & +4.61 & $=5.17$ & \\
\hline
\end{tabular}


Table 4.6. Summation of Dose Estimates for Modes of Exposure Considered, Watershed 2, Route 25. Exposure starting 5 years after the first detonation.

\begin{tabular}{|c|c|c|c|c|c|c|c|c|c|c|c|}
\hline \multirow{2}{*}{$\frac{\begin{array}{l}\text { Body } \\
\text { Organ }\end{array}}{\text { Total Body }}$} & \multirow{2}{*}{$\begin{array}{l}\begin{array}{l}\text { Critical } \\
\text { Population }\end{array} \\
\text { Cuna }\end{array}$} & \multirow{2}{*}{$\frac{\begin{array}{l}\text { Critical Age } \\
\text { Group (years) }\end{array}}{0-1}$} & \multicolumn{4}{|c|}{$\begin{array}{l}\text { Estimated Dose (rem) to } \\
\text { Age } 70 \text { years } \\
\text { (Internal + External) }\end{array}$} & \multicolumn{5}{|c|}{$\begin{array}{c}\text { Estimated Maximum Annual Dose Rate } \\
\text { (rem/year) } \\
\text { (Interril + External) }\end{array}$} \\
\hline & & & 0.00269 & + & $3.57=$ & 3.57 & $<$ & 0.001 & +0.306 & $=0$ & 0.306 \\
\hline Bone & Cuna & $0-1$ & 0.129 & + & $3.57=$ & 3.70 & & 0.0037 & +0.306 & $=0$ & 0.310 \\
\hline Liver & Cuna & $>15$ & 0.0105 & + & $3.57=$ & 3.58 & $<$ & 0.001 & +0.306 & $=0$ & 0.306 \\
\hline KIdneys & Cuna & $>15$ & 0.020 & + & $3.57=$ & 3.59 & & 0.001 & +0.306 & $=0$ & $0.30 \%$ \\
\hline Thyroid & Cuna & $0-1$ & 0.00269 & + & $3.57=$ & 3.57 & $<$ & 0.001 & +0.306 & $=0$ & 0.306 \\
\hline Testes & Cuna & $0-1$ & 0.00269 & + & $3.57=$ & 3.57 & $<$ & 0.001 & +0.306 & & 0.300 \\
\hline Ovarles & Cuns & $0-1$ & 0.00269 & + & $3.57=$ & 3.57 & $<$ & 0.001 & +0.306 & $=0$ & 0.306 \\
\hline Iungs & Cuna & $0-1$ & 0.00269 & + & $3.57=$ & 3.57 & $<$ & 0.001 & +0.306 & $=0$ & 0.306 \\
\hline GI Tract & Cuna \& Negro & $0-1$ & 0.00606 & + & $357=$ & 3.58 & & 0.001 .4 & +0.306 & $=u$ & 0.307 \\
\hline
\end{tabular}


Table 4.7. Summat1on of Dose Est1mates for Modes of Ibxposure Cona1dered, Waterahed 2, Route 25. Exposure starting 30 years after the flrat dotonation.

\begin{tabular}{|c|c|c|c|c|c|c|c|}
\hline \multirow{2}{*}{$\begin{array}{l}\text { Body } \\
\text { Organ } \\
\text { Total Body }\end{array}$} & \multicolumn{3}{|c|}{$\begin{array}{l}\text { Estimated Dose (rem) to } \\
\text { Age } 70 \text { years } \\
\text { (Internal + External) } \\
\end{array}$} & \multicolumn{4}{|c|}{$\begin{array}{c}\text { Eotimated Maximum Annuel Dose Rate } \\
\text { (rem/ yoar) } \\
\text { (Intermal + Bxternal) }\end{array}$} \\
\hline & 0.00114 & +1.44 & $=1.44$ & $<0.001$ & +0.047 & $=0.047$ & \\
\hline Bone & 0.0514 & +1.44 & $=1.49$ & 0.0023 & +0.047 & $=0.049$ & \\
\hline Ifver & 0.00418 & +1.44 & $=1.44$ & $<0.001$ & +0.047 & $=0.047$ & \\
\hline Kidneys & 0.00602 & +1.44 & $=1.45$ & $<0.001$ & +0.047 & $=0.047$ & \\
\hline Thyrold & 0.00114 & +1.44 & $=1.44$ & $<0.001$ & +0.047 & $=0.047$ & \\
\hline Testes & 0.00114 & +1.44 & $=1.44$ & $<0.001$ & +0.047 & $=0.047$ & \\
\hline Ovaries & 0.00114 & +1.44 & $=1.44$ & $<0.001$ & +0.047 & $=0.047$ & \\
\hline Lunge & 0.00114 & +1.44 & $=1.44$ & $<0.001$ & $+0.04 ?$ & $=0.047$ & \\
\hline GI Tract & 0.00256 & +1.44 & $=1.44$ & $<0.001$ & +0.047 & $=0.047$ & \\
\hline
\end{tabular}


Other statements made in reference to Route 17 (see section 4...4) are also applicable here. Figure 4.3 shows the total estinated dose: to total body as a function of reentry tive for a period extending to 50 years after the first detonation.

\subsection{I.imitations of These Dose Estimates}

Wone of the estimates of potential doses in this report has considered possible exposures from l) the nonreleased (i.e., initially) radioactivity produced by the muclear explosives, and 2) the released radioactivity that is not deposited locally, but which enters the stratosphere and becomes a part of world-wide fallout. Acceptable days for the detonations could be selected so that conditions are favorable for limiting the height of the main cloud to approximately 40,000 feet for the large detonations, avolaing the stratosphere which lies at approximately 55,000 feet in the equatorial zone. There is no similar procedure that cen be followed to reduce or confine the nonreleased radioactivity in the excavation, other than to design explosives that produce less radioactivity. Behavior of the nonreleased radioactivity left in the crater is a matter of conjecture, particularly when water flows through the finished canal. In our opinion, considerable uncertainty exists in any predictions of the fate and effects of radioactivity from this source on man. However, BCL has indicated that their marine internal dose estimates include this nonreleased radioactivity.

Dose estimates can be no better than the imput data used to compute them. Ideally, each dose estimate should be accompanied by some confidence limit and, where this is not possibie or practicable, there should be some indication as to whether the dose estimates are conservative 


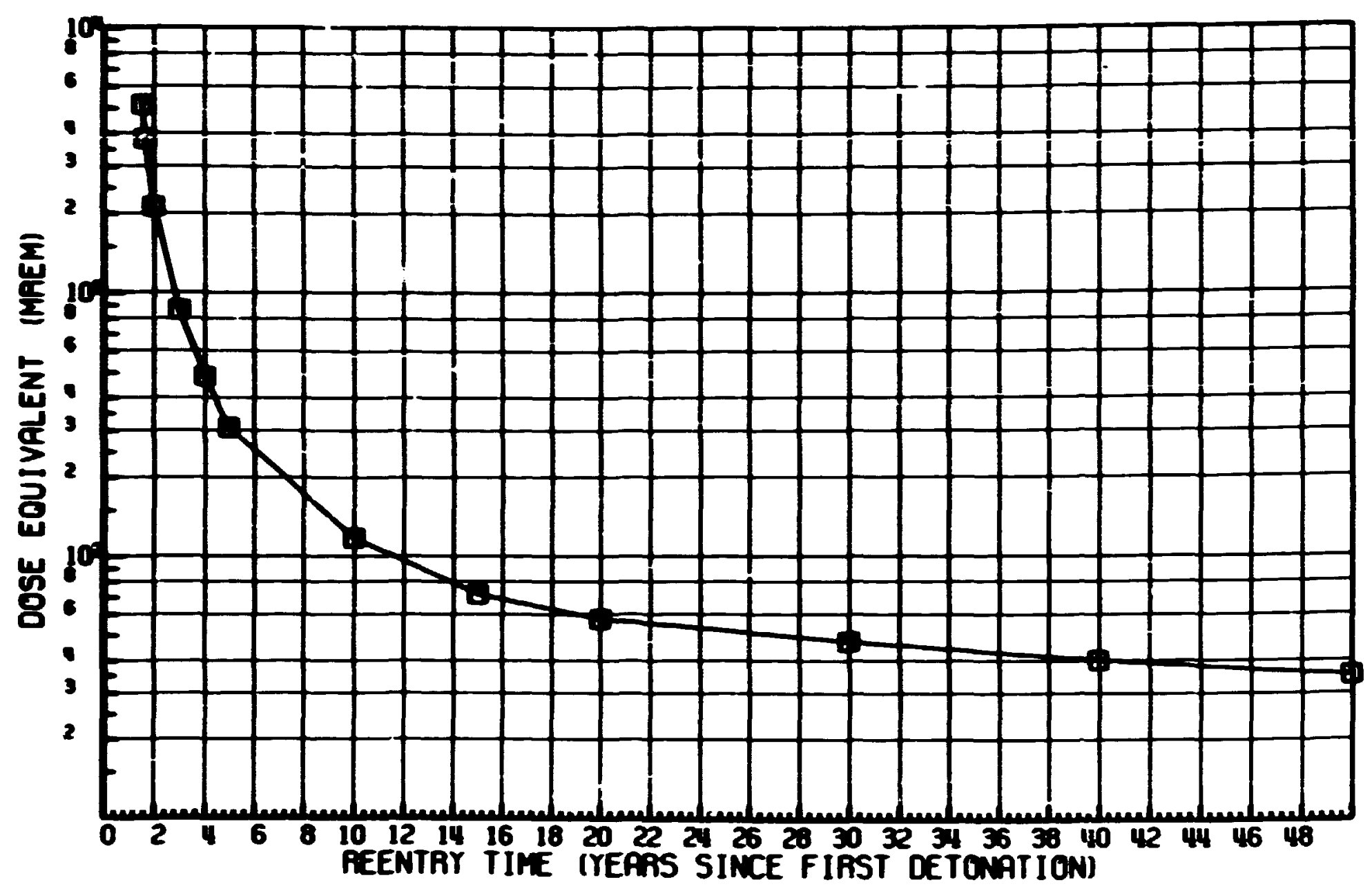

Fig. 4.3. Totai Estimated Mose to the Total Body for Reentry Times up to 50 Years after the First Detonation, Watershed 2, Route 25. 
(assumptions used maximize the dose) or nonconservative (assumptions used do not maximize the dose). Because of uncertainties in the various input data in this study (including the source term! there is no basis on wich to qualify these dose estimates; anything said would be speculation.

The areal deposition $\left(\mu \mathrm{Ci} / \mathrm{cm}^{2}\right)$ or fallout radionuclides was forecast by assuming a re!eased fraction, dispersal of the "cioud," and ary deposition rates. Any of these assumptions could be in error by a considerable margin. Any errors in predicting the fallout deposition of radicnucludes are carried on through to the final dose estimates.

\subsubsection{Bxterral Dose}

Our estimates of external dose are limited to gamma total-body exposures from a radioactively contaminated land surface, and an ancillary evaluation of beta dose to human skin from external beta sources. External exposures might also be possible from submersion in the radiaactive "cloud" (either before deposition or later as a result of resuspension of deposited radioactivity) or from submersion in contaminated water. Inclusion of these additional modes of exposure would probably result in some increase in external dose estimates.

Although each radionuclide produced by the nuclear detonations was not considered in this estimation of external dose, care was taken to include all important radionuclides. Same radionuclides, for which production data were provided, could not be included in our dose evaluations because the gamma spectra were not adequately described in the literature. Omission of these radionuclides is not significant because the quantities produced are relatively small. 
A great jeal of conservatism is built into the estimates of external dose because radioactive decay was the only process considered to alter the concentration on the land surface following deposition. Environmental half-times of the radionuclides were not available, although EXRFM can handle such input as part of th- nuclide decay chain equations. Almost all dose estimates of exposures during the detonation period, and for six months after the last detonation, would be due to radionuclides of relatively shcrt half-lives. Probably no appreciable over-estimate of dose results from neglecting envirommental half-times during this period, if the effective half-time were approximately equal to the radioactive half-life $\left(T_{r}=T=\frac{T_{e} T_{r}}{T_{e}+T_{r}}\right.$, here $T_{r}$ is radioactive half-life. $T$ is effective half-time, and $T_{e}$ is environmental half-time). For periods beginning three years after the first detonation, the largest fraction of potential dose would be contributed by exposures to radionuclides with long radioactive half-lives. If the environmental half.. times were relatively short compared to the radioactive half-iives. for the radionuclides contributing to dose, then the enviromental half-time would be the limiting parameter.

For any dose integration period, what is the magnitude of conservatism of a dose Estimate calculated with $T=T_{r}$ vs. a dose estimate calculated with $T=\frac{T_{e} T_{r}}{T_{e}+T_{r}}$ ? If $F(t)$ represents the magnitude of conservatism of an estimated dose for a specified time period due to consideration of radicscive half-infe criy, then

$$
F(t)=\frac{D_{T}(t)}{D_{T}(t)}
$$


where $D_{T_{I}}(t)=$ cumlative external dose calculeted with rodioactivity loss due cnly to radicastive jecey, and

$D_{T}(t)=$ cumuintive external dose calculated with radioactivity losses due to envircmental factors and radioactive decay.

Substituting a simple integral expression (assiming no input from parent radionuclides) for $D_{T}(t)$ and $D_{T}(t)$, we get

$$
F(t)=\frac{k \int_{0}^{t} e^{-\lambda} r d t}{k \int_{0}^{t} e^{-\lambda t} d t} .
$$

where $k$ represents all constant terms necessary to compute dose. Solution of Eqn. (4.2) gives

$$
F(t)=\frac{T_{r}\left(1-e^{-\lambda_{r} t}\right)}{T\left(1-e^{-\lambda t}\right)},
$$

an equation for estimating the magnitude of conservatism due to exclusion of environmental half-times in dose computations. The utilfty of Eq̃. (4.3) is explicit in the family of curves plotted in Fig. 4.4 for ratios of $T_{\mathbf{r}} / \mathrm{T}$ as large as $100 / 1$.

The following is a hypothetical example of how Fig. 4.4 can be used. Assume that 60 percent of the external gamma exposure from 20 to 70 years after the first detonation is due to a single radionuclide. When environmental processes ari considered which might 


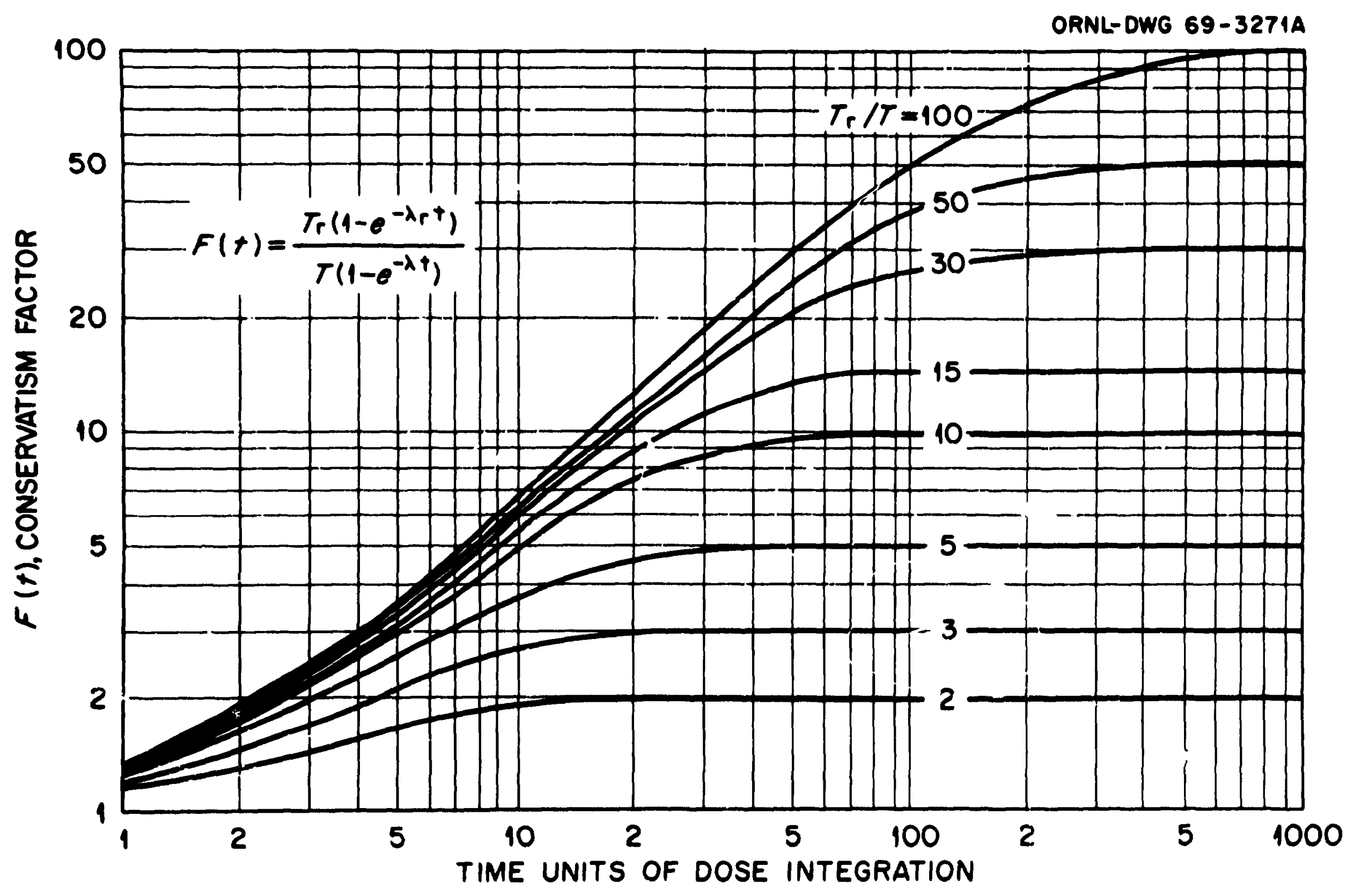

F1g. 4.4. Graph of Conservat1sm Factors for Correcting External Dose Estimates that Utilize Radioactive Decay as the Only Process to Reduce the Radiation Fleld. 
hasten the loss of this radionuclide from the land surface (exclusive of radioactive decay), the ratio $T_{r} / T$ is found to be as high as 90. Dcse estimates using only the radicactive half-life would be conservative by a factor of approximately 25 (see Fig. 4.4). Since this radionuclide in this example, contributes 60 percent of the external exposure for the period 20 years to 70 years after the first detonation, then the total dose estimated for all radionuclides during this periol would be conservative by a factor of $25 \times 0.6=15$. This example shows how it might be possible to reduce the estimates of potential external dose if the required data on environmental balf-times vere available from field experiments in Panama and Colombia. If the ratio of $T_{x} / T$ were taken to be only 30, then the conservatism factor would be 13 for the example radionuclide. Fivis, a reduction $T_{r} / T$ by a factor of 3 recuces the conservatism by only a factor of 2, indicating that the envirommental half-time necd not be known accurately.

Continious external exposure was assumed for calculating the estimates of potential external dose in this study. If this daily exposure time were reduced to 12 or 8 hours per day, the estimates of total dose woula be reduced proportionately by a factor of 2 or 3 . Such a reducision might not be resiistic in all cases because many natives spend a considerable amount of time out of doors, many houses do not have walls to provide radiation sinielding, and many of the local building materials have little value as radiation shielding. Therefore, better estimates of daily exposure times of these populations may not be as important as estimates of the envirommental half-times of radionuclides on the land surface. 


\section{3.:- Internal Dose}

Internal dose has been estimated only for ingestion of contaminated foods and beverages. While irgestion would probably be the internal exposure mode of primary importance for this feasibility study, other modes of internal exposure have tco much potential importance to be ignored. Inhalation exposure sould become very important if the exclusion area were violated by members or the indj.genous populations, or a "cloud" of vented radioactivity were to take an unexpected course over a popuiated area. We do not tave adequate dose estimates with wich to evaluate the potentiai seriousness of such eventualities.

Detailed internal dose estimates for each route were limited to 31 radionuclides which have the greatest dose potentials. This is based on ail exposures starting no less than 30 days after the last detonation.

We attempted to identify critical segments within the four ethnic populations in our estimations of potential dose. Agedependent parameters in sur dose models, however. vere evaluated largely on the basis of data drawn from Caucasian populations quite different from those living along the two proposed canel routes. In addition, the paucity of pertinent anatomical, physiological, and metabolic data has forced us in some cases to apply sidult dosimetry parameters to all age groups, including children. 
Reference for Chapter 4.0

4.1 Fenoral Radiation Council, Background Raterial for the

Development of Radiation Protection Standards, Report No. 1, U.S. Govt. Ptg. Off., Wash., D.C. (May 1960). 


\subsection{COMPAFISON OF DOSE ESTIMATES WTTH RADIATTON SAFETY CRTTERIA ${ }^{2}$}

The radiation safety criteria used for this study have ban reported previously, ${ }^{5.1}$ following the lead of recognized raliation protection authorities. ${ }^{b}$ The basic recaumendations of these authorities apply to radiation doses from all sources other than natural background and meciical sources. Our radiation safety criteria for this study vere originally proposed on the assumption that the dose estimates to which these criteria might apply would include dose estimates for each radionuclide and each exposure pathray. That is to say, it was assumed that a rsther detailed assessment would be made of all potential exposure situations, more or less as they might be expected to occur in the "real" world, simulating or constructing these exposure situations with real information or educated assumptions. As events have derzloped, this radiological safety assessment does not meet that standard, but it =ay ve acequate for purposes of a feasibility study.

The estimates of potential internal doses are based on a systems analysis prediction of radionuclide concentrations in dietary items using the mean areal fallout concentration $\left(\mu \mathrm{Cl} / \mathrm{cm}^{2}\right)$ in a reference watershed (watershed 5 for Route 17, and watershed a for Route 25) as the imput data. Internal dose estimates for other vatersheds are obtained by applying factors based on areal fallout concentrations, relying on the premise that all watersheds are identical in all

\footnotetext{
This term is adopted to avoid any confucion with terms used by recognized authorities to designate their official guides.

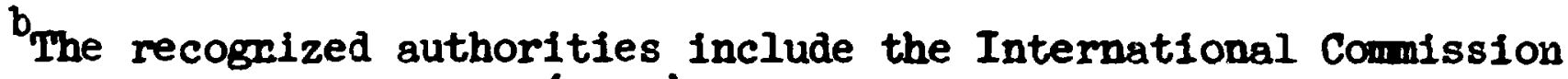
on Radiological Protection (ICRP), the International Atomi I Energy Agency (IAEA), the National Council on Radiation Protection and Measurements (KCRP), the Federal Radiation Counc1l (FRC), and the British Medical Research Council (MRC).
} 
parameters influencing internal dose other than the average initial areal fallout concentration. Sucin a simplification of the canal environent and an assuned behavior of radionuclides in food-chain pathrays can hardly be expected to simulate the actual situation.

The eistimates of potential internal doses used in these comparisons are the highest ones estimated for any of the considered ethnic or age groups living near the proposed canal aligments.

\subsection{Assessment ${ }^{c}$ of the Potential Doses Bstimated for Various Times of Reentry to Watershed 5, Route 17}

Estimated doses assessed here include the contributions from external exposure to the contaminated land surface and from internal exposure via ingestion of contaminated foods and bererages. Assessment of the estimated dose for a given organ is chtained by a simple comparison with the appropriate radiation safety criteria. Pollowing a procedure for handling multiple organ exposures suggested by the ICRP, if three or more organs each could receiva more than one-half their respective maximu permissible doses (criteria), the exposure was regarded as one which would result in a dose exceeding the criteria. 5.2

All assessments are tabulated as functions of exclusion area reentry time (actually the assumed time of reentry to watershed 5). Reentry to other watersheds within the exclusion area might be possible at earlier times because the average initigl fäilout concentretions are lover in all stocr watersheds (see Table 2.3).

CAssesement as used in this report has the following specific meaning: Assessment $=$ dose estimate $\div$ criterion. 
We do not believe an assessment of less than 1.0 for any particular comparison necessarily indicates rediological safety feasibility. As we stated before, even if one had a high degree of corfidence in these dose estimates and their corresponding assessinents, further .udgments and adjustments vill need to be considered so that not all of each criterion is "used up" by this one exposure situation. 1.e.: excavation with nuclear explosives.

\subsubsection{Maximum Amnual Doses}

Assessments pertaining to estimates of average annual dose to critical population groups for varicus assumed times of reentry to watershed 5 are listed in Table 5.1. Children ranging up to 5 years old constitute the critical population group in most of these assessments. Wo clear dependence of dose upon ethnic background is apparent from the dose estimates obtained in this study.

Since the ICRP does not provide guidance on the apportionment of somatic dose, this matter should probably be considered at the national level. Even without apportionment, it can be seen from the assessments listed in Tabie 5.1 that the criteria for total body and gonads might still be exceeded 5 years after the first detonation. Ten years after the first detonation, ofitiple organ exposures should not be excessive, and all assessments would be less than 0.5 , suggestine that reentry to watershed 5 may be possible at that time. Since the input data $\left(\mu \mathrm{Ci} / \mathrm{cm}^{2}\right)$ used for these dose estimates are averages for the vatershea based on fallout con'ours that vary by orders of magnitude over the watershed, some parts of this watershed (and other wate:sheds) probably could be reentered earlier, while other areas may not be safe for longer than 
Table 5.1. Aavessmunto of bst1mated Average Annual Doses to Critical Populution (iroups for Vartour Aaulused Times of Reentry to Watershed 5, Route $1 \%$

Alueuem nt a dose estimate + criterion.

\begin{tabular}{|c|c|c|c|c|c|c|c|c|c|c|c|}
\hline \multirow[b]{2}{*}{$\begin{array}{l}\text { Body } \\
\text { Crean }\end{array}$} & \multirow[b]{2}{*}{$\begin{array}{l}\text { Radlation } \\
\text { Sinfety } \\
\text { Criterla } \\
\text { (rems / yoar) }\end{array}$} & \multicolumn{10}{|c|}{ Assessmente Colncident with Varlous Reentry IImes } \\
\hline & & $\begin{array}{l}30 \text { Days } \\
\text { After } \\
\text { Lautb } \\
\text { Detonation }\end{array}$ & $\begin{array}{l}60 \text { Days } \\
\text { After } \\
\text { Lautb } \\
\text { Detanation }\end{array}$ & $\begin{array}{l}3 \text { Years } \\
\text { After } \\
\text { firat } \\
\text { Detonation }\end{array}$ & $\begin{array}{l}3 \text { Year } \\
\text { After } \\
\text { flrot } \\
\text { Detonation }\end{array}$ & $\begin{array}{l}10 \text { Years } \\
\text { After } \\
\text { Firet } \\
\text { Detonation }\end{array}$ & $\begin{array}{l}15 \text { Yeara } \\
\text { After } \\
\text { Flrat } \\
\text { Detonation }\end{array}$ & $\begin{array}{l}20 \text { Years } \\
\text { Arter } \\
\text { Sirst } \\
\text { Detonation }\end{array}$ & $\begin{array}{l}30 \text { Years } \\
\text { Afier } \\
\text { Flrst } \\
\text { Detonation }\end{array}$ & $\begin{array}{l}40 \text { Years } \\
\text { After } \\
\text { F1rct } \\
\text { Detonat: on }\end{array}$ & $\begin{array}{l}30 \text { Years } \\
\text { Arter } \\
\text { First } \\
\text { Detonation }\end{array}$ \\
\hline Total Body & 0.170 & $1 \%$ & 11. & 3.5 & 2.2 & 0.30 & 0.19 & 0.16 & 0.13 & 0.21 & 0.087 \\
\hline Bone & 2.00 & 1.2 & 3.4 & 1.9 & 0.23 & 0.003 & 0.043 & 0.0137 & 0.032 & 0.029 & 0.015 \\
\hline Lves: & 0.500 & 6.3 & $1 . .1$ & 2.0 & 0.41 & 0.10 & 0.065 & 0.053 & 0.043 & 0.038 & 0.030 \\
\hline KIdneys & 0.500 & 22. & 7.8 & 2.8 & 0.41 & 0.10 & 0.063 & 0.053 & 0.044 & 0.038 & 0.030 \\
\hline Thyroid & 0.500 & 25. & 6.9 & 1.9 & 0.41 & 0.10 & 0.065 & 0.0132 & 0.043 & 0.038 & 0.030 \\
\hline Teutes & 0.170 & 28. & 12. & 3.3 & 1.2 & 0.30 & 0.19 & 0.16 & 0.13 & 0.11 & 0.087 \\
\hline Ovartes & 0.270 & 27. & 11. & 3.5 & 1.2 & 0.30 & 0.29 & 0.26 & 0.13 & 0.21 & 0.087 \\
\hline Lunge & 0.300 & 3.9 & 3.9 & 2.9 & 0.41 & 0.10 & 0.065 & 0.053 & 0.043 & 0.038 & 0.030 \\
\hline GI Tract & 0.300 & 5.9 & 4.2 & 2.6 & 0.46 & 0.11 & 0.071 & 0.058 & 0.048 & 0.042 & 0.050 \\
\hline
\end{tabular}

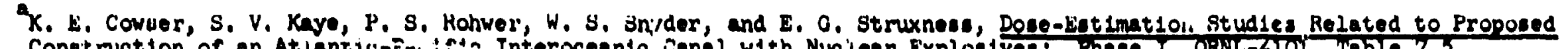

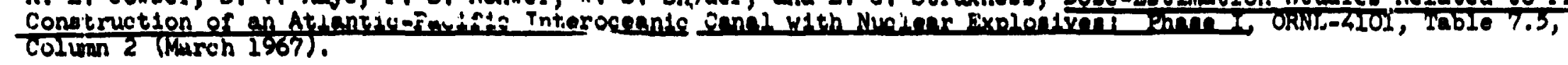

beast dotonation 182.57 yoars arter tha sirut celonation. 
10 years. Generally speaking, predicted fallout concentrations decrease as one moves away from the proposed canal alignment, suggesting that outer areas of the exclusion area could te reentered first. There are, however, factors other than radiation to be considered.

\subsubsection{Genetically Significant Doses}

The ICRF states that genetic dose should not exceed 5 rems/30 years for all sources excluding the dose from natural vackground radiation and from medical procedures. 5.3 No speciai evaluations are required to apply this criteifion to assessments of genetically significant dose in Table 5.z. If an assessment of 0.5 is acceptable (see section 2.7.3), then reentry could take place as early as 3 years after the first detonation. This assessment indicates that somatic dose (Table 5.1) would be more limiting than genetic dose.

\subsection{Assessment of the Potential Doses Bstimated for Various Times of Reentry to Watershed 2, Route 25}

Assessments for watershed 2, 3uute 25, are similar to those for watershed 5, Route 17 (i.e., dose estimates are for the same exposure mcdes: iủentical assessment procedures aie used; and the assessment result,s are similar). Because the assessments for the twu routes were parallel, all discussions relative to Route 17 (see section 5.1) are applicable ior Route 25 also, and the reader is referred to that section for details. 
Table 5.2. Assessments of Estimated Genet1cally Significant DoBes to Crit1cal Population Groups for Varlous Assumed Times of Reeutry to Watershed 5; Route 17.

Assessment $=$ dose estimate + criterion.

\begin{tabular}{|c|c|c|c|c|c|}
\hline \multirow[b]{2}{*}{ Reentry I1mes } & \multirow{2}{*}{$\begin{array}{c}\text { Radiat1un } \\
\text { Safety } \\
\text { Criter1a } \\
\text { (rems / 30 Yoars) }\end{array}$} & \multicolumn{4}{|c|}{ Assessmerits for the Virrious Populations } \\
\hline & & $\begin{array}{l}\text { Cuna } \\
\text { Indlens }\end{array}$ & $\begin{array}{l}\text { Choco } \\
\text { Ind1ens }\end{array}$ & Negroes & Colon1sts \\
\hline 30 days after last ${ }^{b}$ detorkation. & 5 & 0.73 & 0.78 & 0.77 & 0.79 \\
\hline 60 days after last ${ }^{b}$ detonation & 5 & 0.61 & 0.64 & 0.64 & 0.64 \\
\hline 3 years after f1rst detonation & 5 & 0.45 & 0.46 & 0.46 & 0.46 \\
\hline 5 years after flrat detonation & 5 & 0.21 & $0.2 i$ & 0.22 & 0.2 .2 \\
\hline 10 years after f1rst detonation & 5 & 0.12 & 0.12 & 0.22 & 0.12 \\
\hline 15 years arter f1rat detonation & 5 & 0.097 & 0.097 & 0.097 & 0.097 \\
\hline 20 years after I1rat detchation & 5 & 0.086 & 0.086 & 0.086 & 0.086 \\
\hline 30 years arter 11 r.st detchation & 5 & 0.075 & 0.075 & 0.075 & 0.075 \\
\hline 40 years after f1rst detonation & 5 & 0.065 & 0.065 & 0.065 & 0.065 \\
\hline 50 years after s1rst dutanation & 5 & 0.048 & 0.048 & 0.048 & 0.048 \\
\hline
\end{tabular}

OK. E. Cowser, S. V. Kavm, P. 3. Rohwer, W. 3. Snyder, and. E. U. Struxness, Dose-Estimation Studies Kelated to Propoend Construction of an At lant 1c-Pac1f1c Interocean1c Canal w1 th Nuclear Borplosives: Phase I, ORNL-4101, p. 89 (1)arch 1967).

blast datonation 1. 2.57 years after the f1rat detonation. 


\subsubsection{Narimum Annual Doses}

Assessments of estimated average annual doses are presented in Table 5.3 for age and ethuic groups receiving the highest estimated doses. In most cases, that group was between 0 and 5 years of age and there was no consistent pattern relative to ethnic background. Reentry, on the basis of somatic dose assessments, may be possible less than 10 years after the first detonation.

\subsubsection{Genetically Significant Doses}

Assessments of genetically significant dose for each of our ethnic groups for various assumed times of reentry to watershed 2 are listed in Table 5.4. If an assessment of 0.5 is acceptable, the values presented in Table 5.4 suggest that reentry could take place less than 5 ycars after the first detonation. As was the case for Route 17, genetic dose limitations appear to be less restrictive than those for somatic dose. 


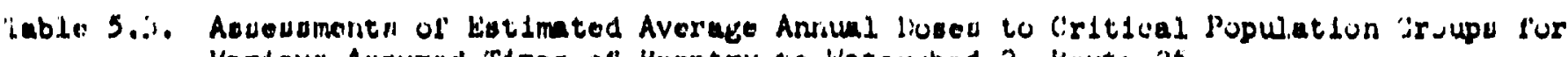
Varloud Anowned TImes of Keentry to Waterched 2, Koute 23.

Ausesament - duse pitilinate it criturion.

\begin{tabular}{|c|c|c|c|c|c|c|c|c|c|c|c|}
\hline \multirow[b]{2}{*}{$\begin{array}{l}\text { Body } \\
\text { Orean }\end{array}$} & \multirow[b]{2}{*}{$\begin{array}{l}\text { Kadtation } \\
\text { infoty } \\
\text { (iriterito } \\
\text { (reme / your) }\end{array}$} & \multirow[b]{2}{*}{$\begin{array}{l}30 \text { Jays } \\
\text { Artof } \\
\text { Laur } \\
\text { Detonation }\end{array}$} & \multirow[b]{2}{*}{$\begin{array}{l}60 \text { inyo } \\
\text { After } \\
\text { Lautb } \\
\text { Detonation }\end{array}$} & \multicolumn{7}{|c|}{ 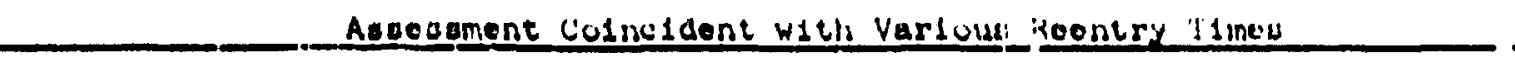 } & \multirow[b]{2}{*}{ 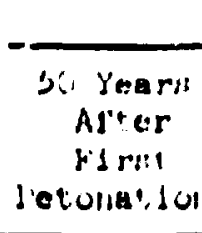 } \\
\hline & & & & $\begin{array}{l}2 \text { Yeare } \\
\text { After } \\
\text { Firut } \\
\text { Detomation }\end{array}$ & $\begin{array}{l}\text { S Yoary } \\
\text { After } \\
\text { F1rut } \\
\text { Dotorution }\end{array}$ & $\begin{array}{c}10 \text { Ymax's } \\
\text { Astios } \\
\text { rd rest } \\
\text { Detonat lun }\end{array}$ & $\begin{array}{l}15 \text { Years } \\
\text { A terer } \\
\text { Firut } \\
\text { detorution }\end{array}$ & $\begin{array}{l}20 \text { Years } \\
\text { Arter } \\
\text { Firat } \\
\text { Lelunation }\end{array}$ & $\begin{array}{c}30 \text { Years } \\
\text { Aftor } \\
\text { sirn! } \\
\text { Detonation }\end{array}$ & $\begin{array}{l}\text { 40) Years } \\
\text { After } \\
\text { birst } \\
\text { Letunatd un }\end{array}$ & \\
\hline Total Bouly & 0.270 & 30. & 23. & 13. & 1.8 & 0.68 & 0.42 & $0.3<$ & 0.28 & 0.24 & $ن .2(1$ \\
\hline Bone & 2.00 & 0.0 & 4.2 & 2.1 & 0.31 & 0.12 & $0.0 \%$ & 0.000 & 0.049 & 0.042 & 0.035 \\
\hline Luver & 0.500 & 11. & 8.1 & 4.3 & 0.01 & 0.23 & 0.14 & 0.11. & $0.05 \%$ & 0.080 & $0.0 \%$ \\
\hline KIdney: & 0.500 & 21. & 24. & 3.0 & 0.61 & 0.23 & $0.2 \%$ & 0.1 .1$. & $0.0 \%$ & 0.680 & $0.0 \%$ \\
\hline lhyrold & 0.500 & 21. & 7.9 & 4.2 & 0.01 & 0.23 & 0.14 & 0.11. & 0.094 & 0.080 & $0.0 \%$ \\
\hline reates & 0.170 & 30. & 23. & 13. & 1.8 & 0.68 & 0.42 & $0.3 \alpha$ & 0.28 & 0.24 & $(1 .<0$ \\
\hline Ovartee & 0.170 & 30. & 23. & 13. & 2.8 & 0.68 & 0.42 & 0.34 & 0.23 & 0.24 & 0.20 \\
\hline Lungs & 0.500 & 20. & 7.0 & 4.2 & 0.02 & 0.23 & 0.14 & 0.11 & 0.094 & 0.080 & $0.0 \%$ \\
\hline OI Tract & 0.300 & 10. & 7.8 & 1.04 & 0.61 & 0.23 & 0.14 & 0.11 & 0.094 & 0.080 & $0.0 \% \%$ \\
\hline
\end{tabular}

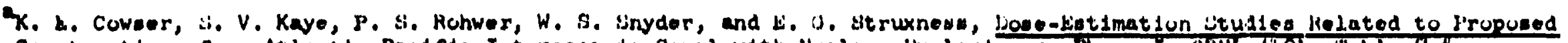

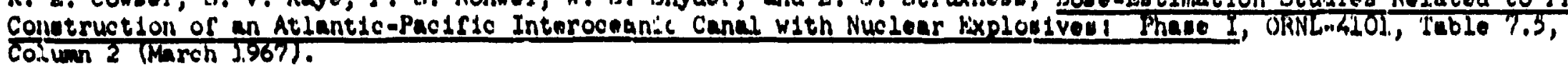

blaut detonation 1. 1.49 yeare arter the f1rot detonation. 


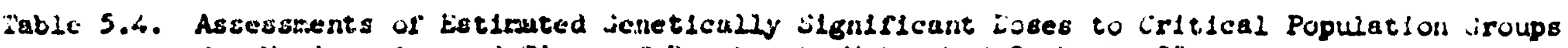
for Varlow: Asoumed iner of Reentry to hatershed 2, ioute 25.

Aosesument $=$ dove ettimati: + eriterian.

\begin{tabular}{|c|c|c|c|c|c|}
\hline \multirow[b]{2}{*}{ Reentry ilmes } & \multirow{2}{*}{$\begin{array}{c}\text { Radiationa } \\
\text { Saiely } \\
\text { Criterla } \\
\text { (rems / } 30 \text { Years) }\end{array}$} & \multicolumn{4}{|c|}{ Assessinents for the iartohs Populat font } \\
\hline & & $\begin{array}{l}\text { Cuna } \\
\text { Indians } \\
\end{array}$ & $\begin{array}{l}\text { Choco } \\
\text { Indians }\end{array}$ & iesproes & Coloniste \\
\hline 30 days arter laut ${ }^{b}$ detoration & 5 & $1.6 \%$ & 1.73 & 1.72 & $1 . \because 2$ \\
\hline 60 days aiter last ${ }^{b}$ dctonation & 5 & 1.42 & 1.45 & 1.45 & 1.45 \\
\hline 2 yearc aiter first detunation & 5 & $1.0: 5$ & 1.06 & 1.08 & 1.00 \\
\hline 5 years arter first detonati un & 5 & 0.40 & 0.40 & j.41 & u. 41 \\
\hline 10 years after first detonation & 5 & $0.2^{\prime \prime}$ & 0.28 & 0.28 & 1.28 \\
\hline 15 years after flrst detanation & 5 & 0.23 & 0.23 & 0.23 & 0.23 \\
\hline 20 yea s after first detona:s on & 5 & 0.20 & 0.20 & 0.20 & $ن .24$ \\
\hline 30 years eifter first detonation & 5 & 0.17 & 0.17 & 0.17 & U.1' \\
\hline 40 years Effter first detonation & .5 & 0.15 & 0.15 & 0.15 & 0.15 \\
\hline 50 years after first detonation & 5 & 0.11 & 0.21 & 0.11 & 0.1 .1 \\
\hline
\end{tabular}

Q. E. Cowser, S. V. Kayc, P. S. Kohwer, W. S. Snyder, and E. G. Struxness, Dose-Lstimation Studies Kelated to Proposed Construction of an Atlant1c-Pac1fic Interoceanj: Canal with Nuclear Explosives: Phase I. URIL-4IOL, p. 89 (hlarch 1967).

bast detonation 151.49 years after the f1rst detonat:on. 
References for Chapter 5.0

5.1 K. E. Cowser, S. V. Kaye, P. S. Rohwer, W. S. Snyder, and E. G. Struxness, Dose Estimation Studies Related to Proposed

Construction of an Atlantic-Pacific Interoceanic Canal with Nuclear Explosives: Phase I, ORNL-4101 (March, 1967).

5.2 International Commission on Radiological Protection, Recommendations of the International Commission on Radiological Protection (Adopted Sept. 17, 1965), ICRP Publ. 9, p. 12, Pergamon Press, London (1966).

5.3 International Comission an Kadiological Protection, Recommendations of the International Commission on Radiological Protection (Adopted Sept. 9, 1958), ICRP Publ. 1, p. 15, para. 64, Pergamon Press, London (1959). 


\subsection{COACLUSIOUS AID RECONIBTATIOAS}

These conclusions apply to both canal routes because of similarities in both assessments. However, in a few cases, the discussion pertains to one route only, because of certain unique environental or human factors involved. These cases are clearly noted.

\subsection{Occupational Workers}

Primary concern in this study has been devoted to estimating potential doses to native populations that could be affected by the proposed project, but some useful information for protecting the occupational workers has also been developed. Occupntional workers are considereci. here to be any persons engaged in canal construction within the exclusion area, after the tire of the first detonation.

Instantaneous dose rates (see Appendix III) are useful for projecting the eppicinate extermal radiation hazards at 13 locations along Route 17 for any tine up to fonm years after the inftiai detonation. Although there are some linitations for the application of these dose rates (discussed in section 4.1.1), they explicitly show that dose rates decrease approximately a factor of $10 \overline{0}$ duriuts the first month after H +24 . Therefore, reentry of occupational workers after individual detonations should be delayed as long as practicable so that maximum protection will result. The significant reductions In potential exposures taking this factor into account vould probably justify lengthening the time betreen detonations in some cases. 
After the first detonation, all food and vater consumed by occupational workers should be imported from outside the exclusion area. If this precaution is taken, internal exposures from ingestion of radioactive materials vill be essentially eliminated. Some internal exposure is possible from dust stirred up by transportation and excavation equipment. During construction, an air monitoring system should be established at each work site, and face inasks and respirators should be used if necessary. Revegetation of denuded areas and raing conditions should decrease the potential inhalation exposures.

All construction-related field work (e.g., road building, clearing forested areas for canp sites, surveys, etc.) that can be completed before the first detonation should be finstiteu iy that time in order to keep exposures to the lorest practicable levels.

\subsection{Populations Outside the Bxclusion Area}

In the event that a radioactive "cloud" from a nuclear detonation passes over the exclision boundary, a signiflcant anount of radioactivsty wight be deposited on a nearby population center. A potentially hazardous consequence of relocation 18 that people wight be concentrated and living in larger groups (comminties, canps, towns, etc.) than formerly, thus making it possible for a large miber of people to be exposed simultaneously to a radiosetive "cloud" having an unanticipated trajectory.

The following three recomsendstions are put forth to reduce potential raciological hszards to populations outside the exclusion ares rrom accidental deposition of fallout: 
1. Relocate people as far aray from the exclusion boundary as practicable, and avoid areas that have are than a remote possibility of receiving fallout (1.e., northwest and southrest boundaries of the exclusion zone in Panama should be groided).

2. Do not concentrate people so that a large fraction of an ethnic population could be exposed by a single detonation.

3. Emergency planning and indoctrination of all people should be completed before the first detonetion.

Locations for temporary residence of evacuated populations should be chosen with care so that the possibility of a stray "cloud" exposing people is minimized. As stated in the first recumendation, these locations for evacuated populations should be as far array from the exclusion boundary as practicable. The second recomendation is intended to reduce the potential genetic dose (assuming that interethnic breeding is negligible) by not permitting a large fraction of an ethnic population to occupy a single area. Bven though all precautions might be taken to avold the possibility of a cloud passing over relocated populations outside the exclusion zone, emergency plans to mitigate the consequences of such an eventuality should be established. This planning should include everyone in each ethnic group and the responsible officials.

The type and extent of emergency action that might be invoked will depend heavily on the effectiveness of a continuing postdetonation monitoring systam. Such a monitoring system should be an integration of remote monttors and highly mobile survey teams. Procedures should be rorked out beforehand for conflscating or quarantining a food supply, 
or for informing everyone to stay under cover wile a racioactive "cloud" passes over, if necessary. The principal pathray for the spread of radioactivity from a contaminated watershed to an uncontaminated one is via rivers and streams. Therefore, surface vater streams should be monitored in dornstream areas where ground cortamination may be negligible.

\subsection{Reentry of ieneral Fopulation to Bxclision Ares}

The most effective measure for reducing potential exposures of general populations is to evacuate everyone from areas (exclusion areas shown on Figs. 2.1 and 2.2) expected to receive local fallout. This action is practical because radiomuclides contributing nost to external dose have short radioactive half-lives (see Appendices II and III for graphs of dose rate as a function of time). For evacuation to be effective, areas to be covered by local fallout must be predicted accurately, and evacuation wust be complete.

Assuming fallout predictions are ressonably accurate, evacuation of population groups for 3 years (starting at the time of the first detonation) would eliminate approximately 98 percent of the estimated potential dose from all modes of external exposure (see Table 4.1). The highest potential external dose from the contaminated land surface (considering only the 13 locations studied in this report) could be 3 rems for 67 years of exposure at locations 4 and 5. The actual external dose accrued over this period would probably be muab less than 3 rems because environmental factors should reduce considerably the surface dose rate over that perlod of time, all other factors being equal. 
Bstinated internal dose resulting from ingestion of contaminated fools and beverages, like the estinated external dose from the contenineted land surface, can be reducid considerably by short delays in reentry during the early post-muclear-excavation period. Reentry at 5 months, rather than 1 month safter the last detonation should reduce estinated maximm anmual dose rates to various reference organs due to radionuclide ingestion from vatershed 5, Route 17, by factors ranging from 5 to 278, and from watershed 2, Route 25, by factors ranging from 8 to 147. The range in these factors is due prinarily to variations in effective half-times of the ajor dose contributing radiomalides. Similar factors for reentry 30 years, rather than 5 years, after the first detonation range from 1.2 to 7 for both routes. Assuning that the indigenous populations reenter 3 years after the first detonation, the upper estimates of dose comitment due to radiomalide ingestion is 1.6 rems to bone for Route 17; upper estimates of dose comitment for all other reference organs might be lower by a factor of 2.5 or more.

Estimates of maximu sometic dose and genetically significant dose in this report are sumations of the dose estimates for only two modes of exposure. It appears, on the basis of these dose estimetes (see $\mathrm{Figs} .4 .2$ and 4.3), that delays in reentry extending to 7 or 8 years after the first detonation would result in sizsble reductions in doses; beyond that time, further delays of reasonable duration ( $a$ few years) would not reduce the estimated doses appreciably.

Although the presence of a sea-level canal would probably produce some changes in basic sustenance for some grouns, others, especially the Choco and Cuna Incians, yould probably continue their dependence 
upon shifting agriculture and fishing for food. Shifting agriculture is utilized because productivity decreases considerably after one or two years of cultivation. When a garden area is cleared, trees and brush are burned in place to release mutrient elements back to the soil. If this technique is continued, any long-lived radianuclides fixed in plant tissues would be released to the soil and thus wight become available for uptake by crops. This exposure pathray should be of minor importance, but if the soil is poor nutritionally or lacking in clay minerals, the soil-to-root pathray might be of more than minor importance. Monitoring programs should be designed to detect intakes that might be unique to shifting agriculture techniques.

\subsection{Radiological Safety-Feasibility of a Sea-Level Canal Bxcavated with ficlear Bxplosives}

Based on the dose estiation studies reported herein, it is our opinion that a definitive assesement of radiological safety is not possible at this time. This opinion is based on recognition of the fact that all potentially hazardous situations have not been evaluated, and for those that have been evaluated, no reliable estimates of accuracy are possible. Although there appears to be a likelihood of vet deposition, resulting in higher potential doses, no imput data vere provided for rainout conditions.

A realistic assessment of potential radiological hasards cannot be made without wore bicenviromemcel and radiological information. A larger program of investigation is clearly indicated for a profect of this size. The proposed sea-level canal project would involve large land and ocean areas, and affect thousands of people. An uncertainty about the safety of these people and the possible deleterious 
effects on this environent should be reduced to nil before, decision is ade to go ahegd with the project. Por a project of this magnitude and potential inpact, educatad guesses or unfounded sssumtions are not a satisfactory substitute for real data, especially when it is tecanticaily and econonically feasible to procure the necessary data on wich a realistic assessment could be made.

Despite these reservations, ve do not appear to have uncovered any radiological problews that could not be magec by adequate planning and reasonable precautions, with but one exception. The nonreleased radioactivity that would remain in the excavation was not considered in our estimates of potential dose. Most of this radioactivity would be trapped far below the botton of the proposed canal, but the poss1bility thist this radioactivity would be flushed out of the rubble is probably real. There does not appear to be an effective "solution" to this potential problem, nor is it at all certain that the potential exposures resulting therefrom would be significant.

\subsection{Further Research to Improve the Estimates of Potential Dose}

Since all other subcontractors in the bloenviromental progrim provided Inpits to the dose-estimation study, directly or indirectly, any improvements made in these imputs would improve the estimates. He are not in a position to comnent further on the work of otbers. Therefore, the recomendations which follow are relsted to improving the input information used directly in the dose estimation study. 
Internal dose parameters (biological half-time, fraction assimilated, organ mass, and effective absorbed energy) used in the IRREy code are standard-man values or vere derived by performing modifications on standard-man data. Further dose estimation studies should include biological parameters specific for the populations involved. Two types or studies are reccmerded for representative age and ethnic groups: (1) stable element anaiyses of total diet and total excreta over periods of ore month or more, and (2) veight, dimension, ard stable element analyses of organs from cadavers.

Also, data should be cbtained to evaluate fully the three modes of potential exposure conitted in this stuay: submersion in air, submersion in water, and inhalation.

Carefully designed radionuclide tracer studies, involving acderately large plots, should be carried out in enviroments where failcit might be deposited from canal construction. Transfer coefficientis or mathematical functions describing intercompartmental transfers of radionuclides are the major data expected from this research. These data could be ueed (I) to provide better simulations of radionuclide distribution and redistribution in tropical ecosystems, thus resulting in better estimates of potential dally radionuclide intakes, and (2) to estimate the attenuation of the external radiation fisid above the land surface by processes other than radicactive decay. 
APPSADIX I

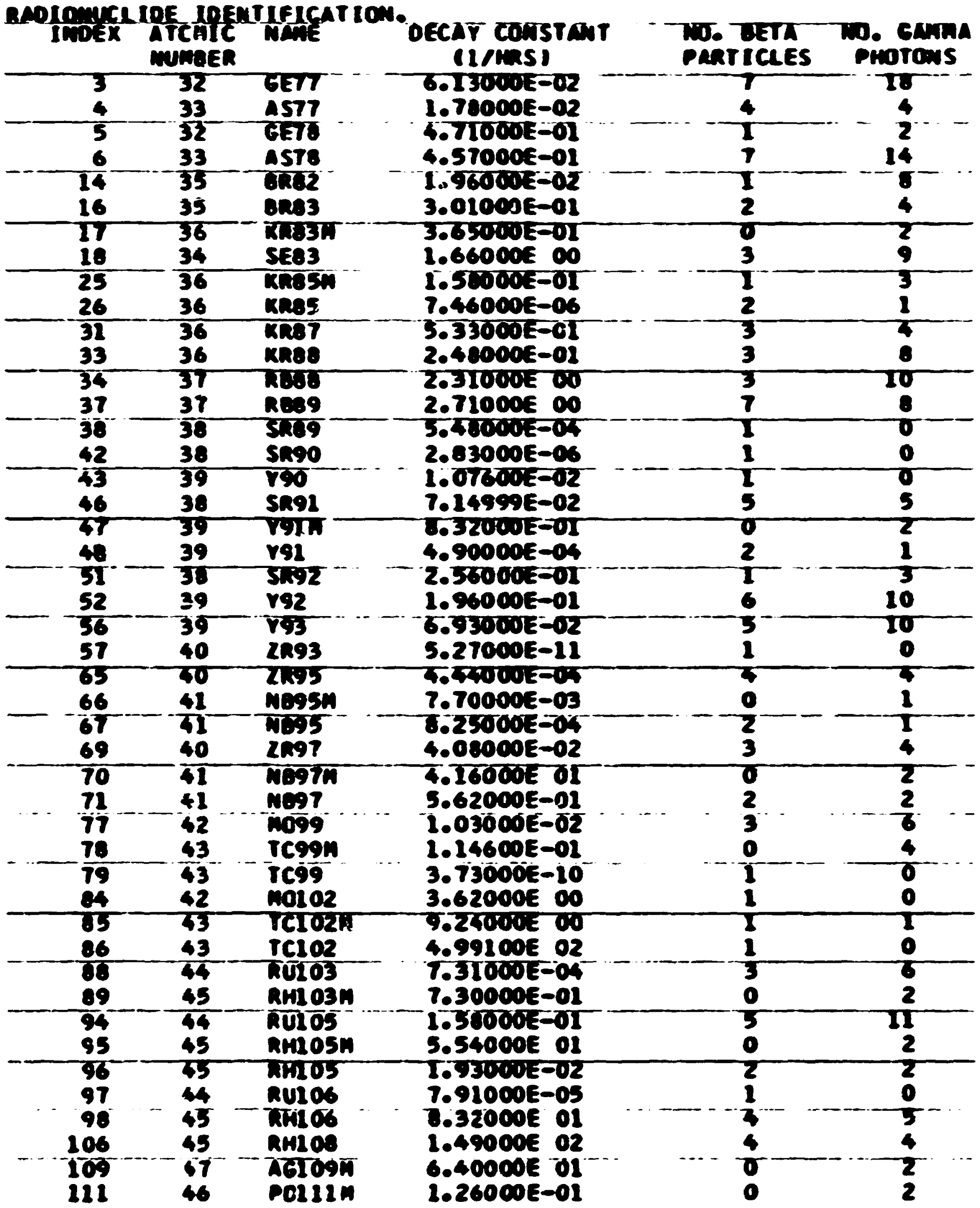


APPEADIX I, Continued

RADIOMUCLIDE IOENTIFICAIION.

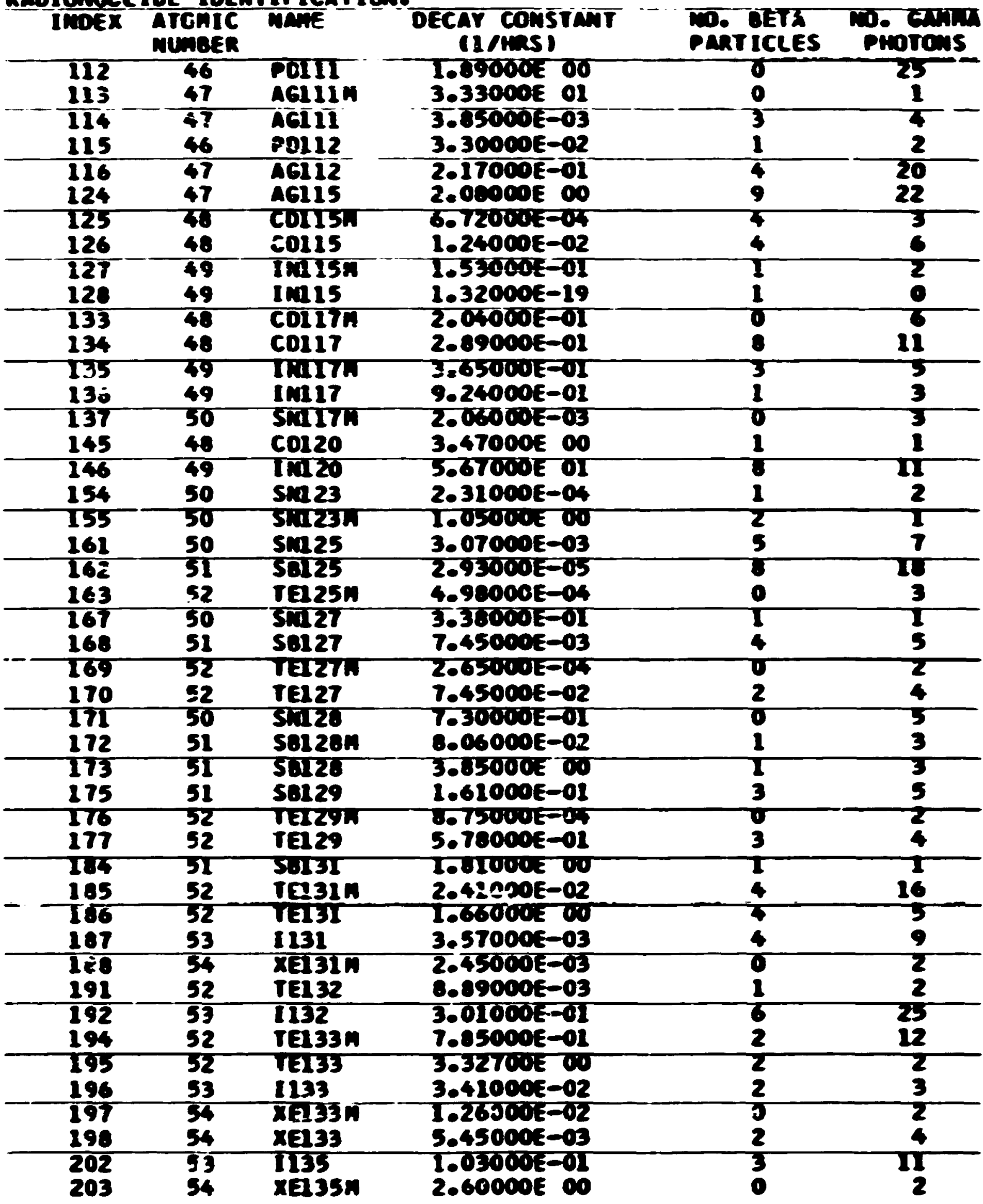


APPEIDIX I, Continued

RADIONUCLIOE IOENTIFICATION.

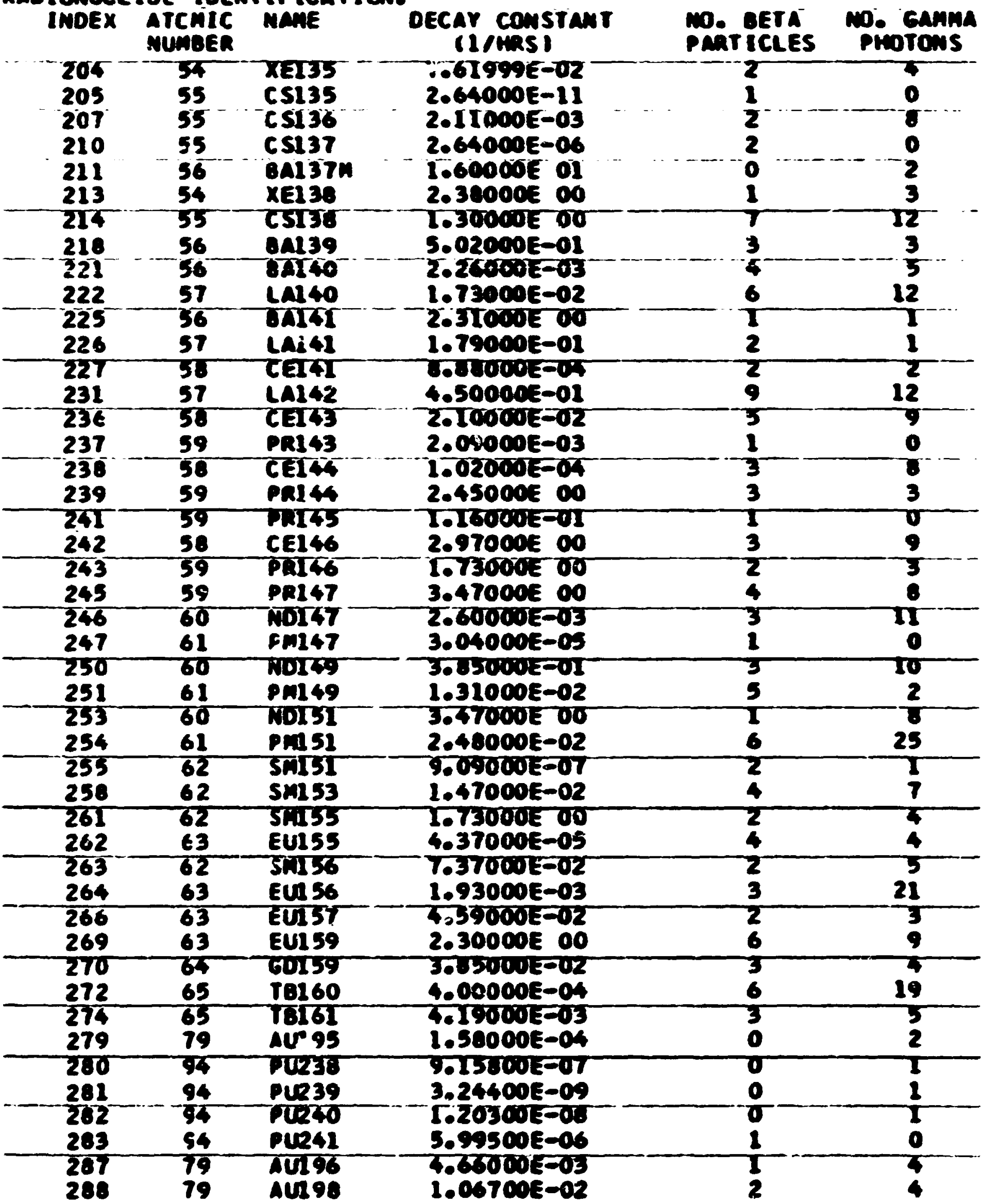


APPETiDIX I, Continued

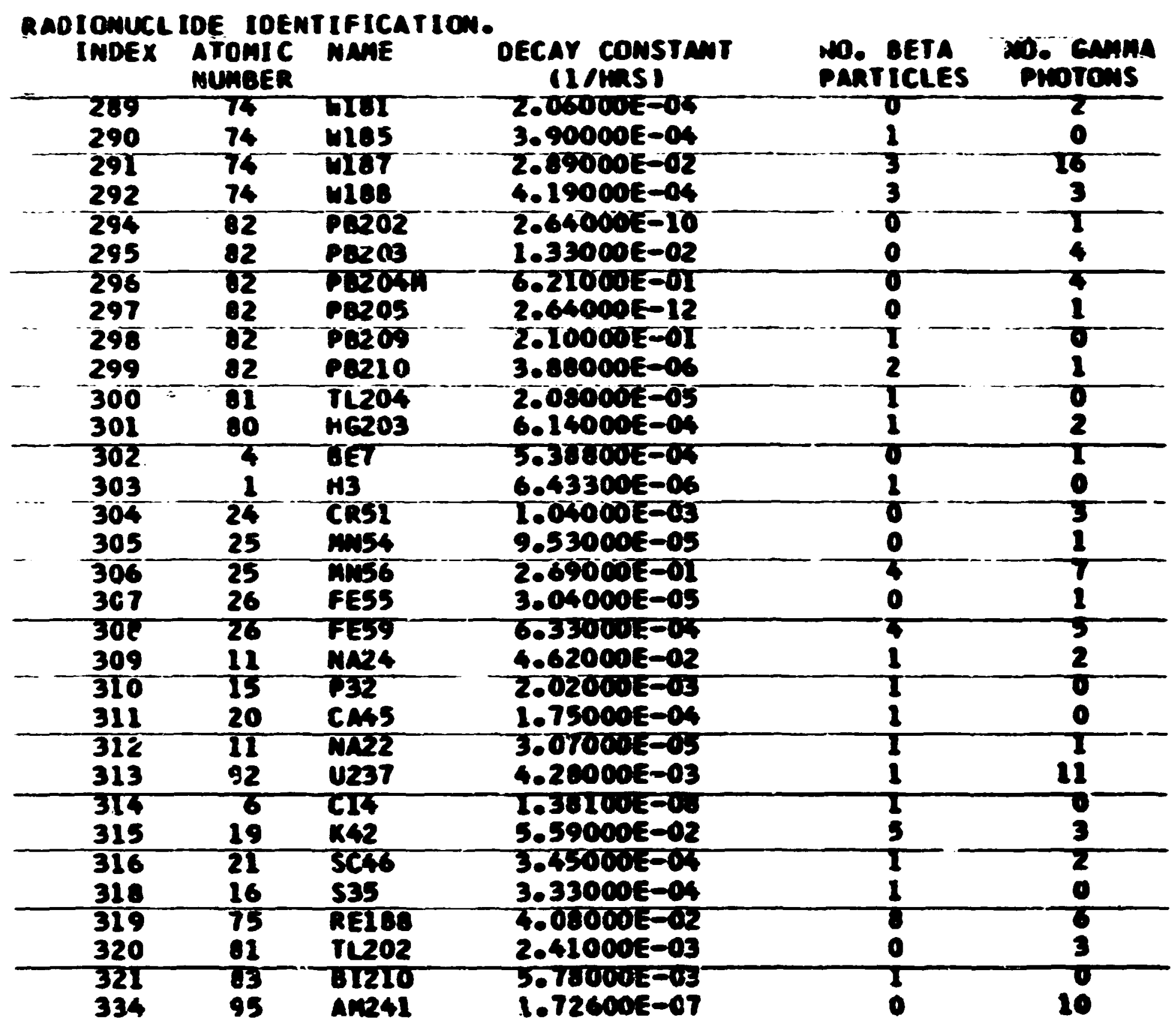


APPBDIX II

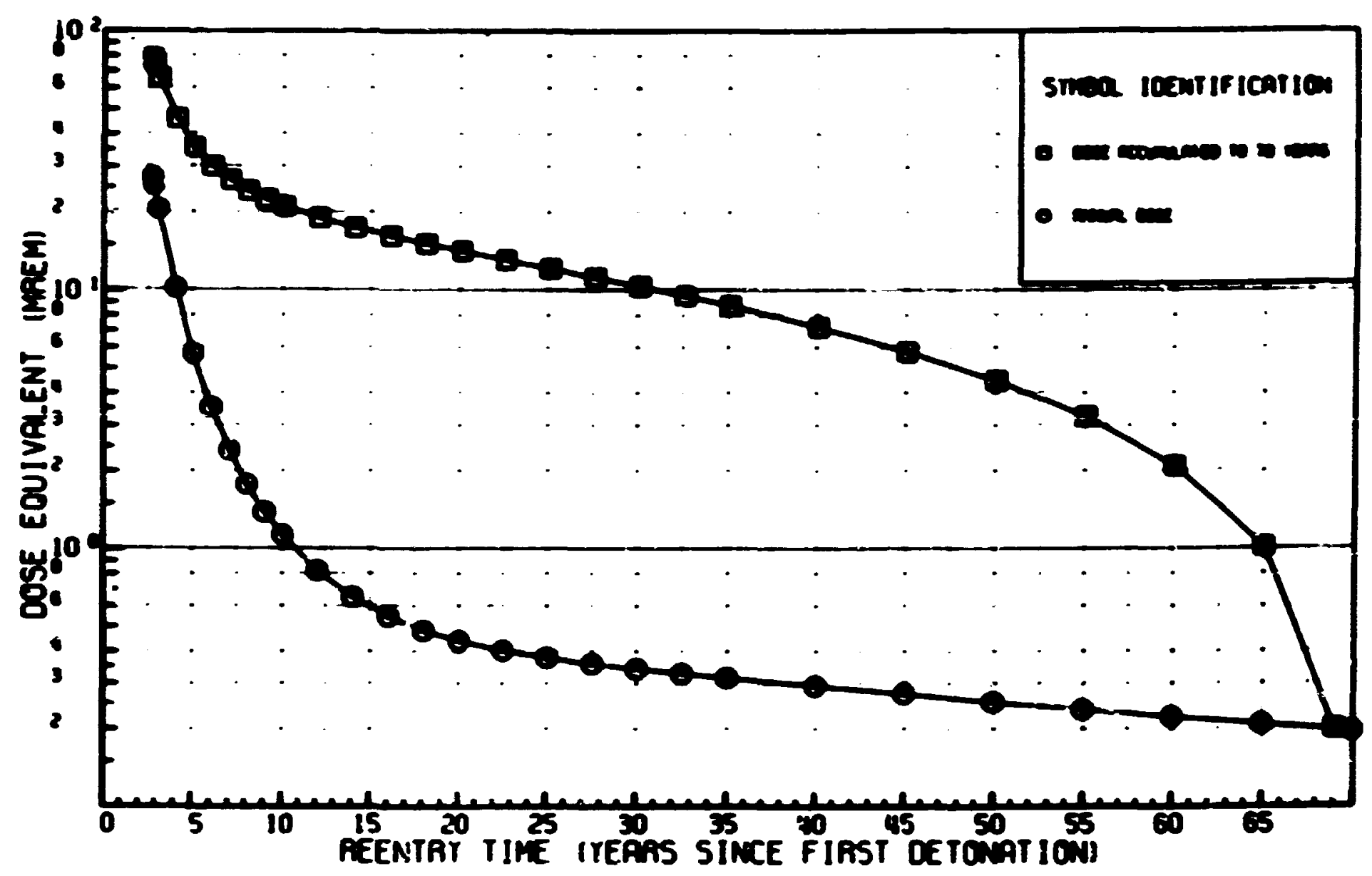

Fig. 1. Bxternal Gam Dore 1 Meter above Landscape (Location 1, San Miguel, Route 17).

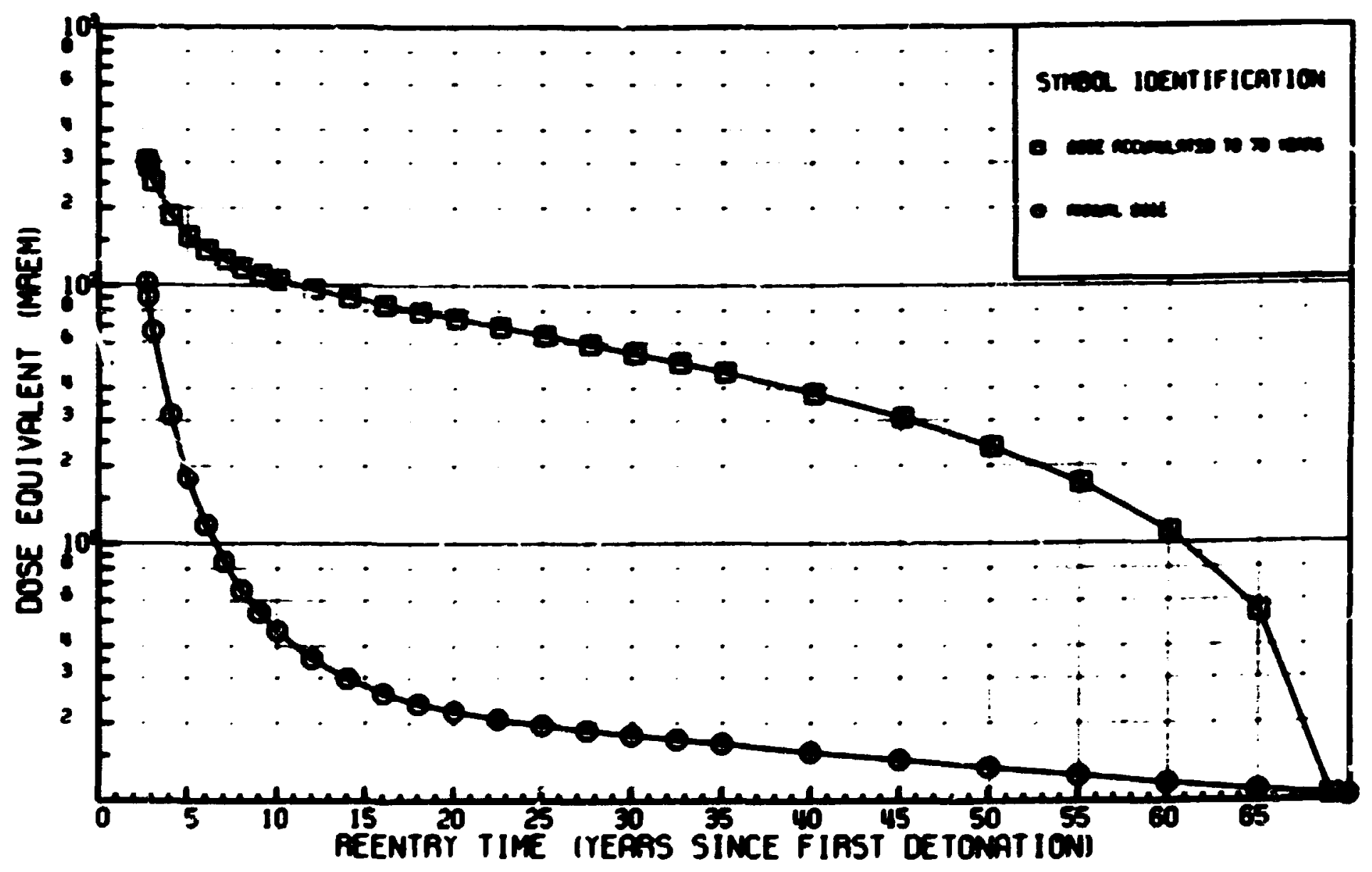

Fig. 2. Buternal Gam Dose 1 Meter aoove Landecape (Location 2, Punts Cocos, Route 17). 
APPG.DDX II, Continued

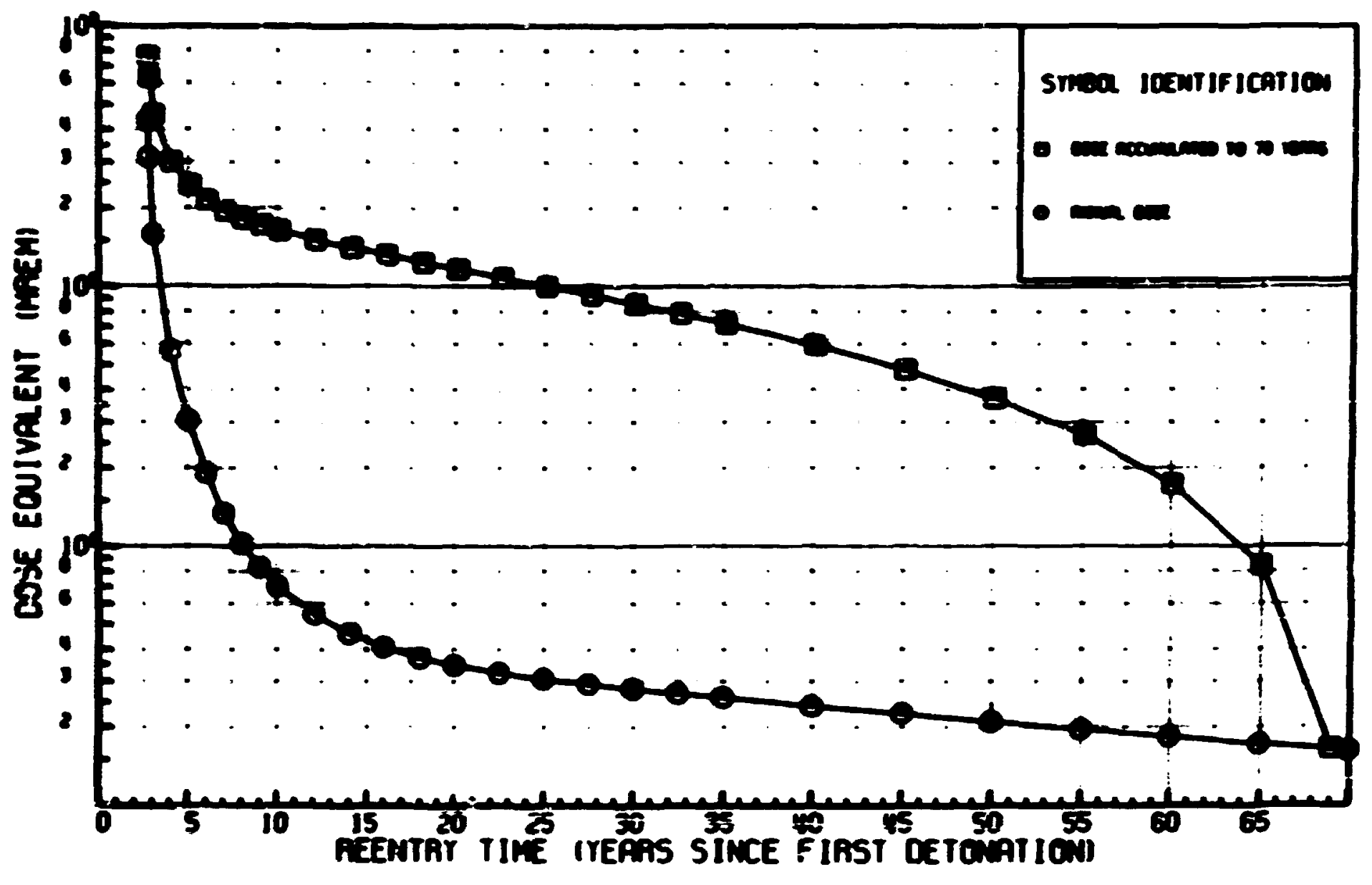

F1g. 3. External Gem Dose 1 Meter above Landscape (Location 3, Carachine, Route 17).

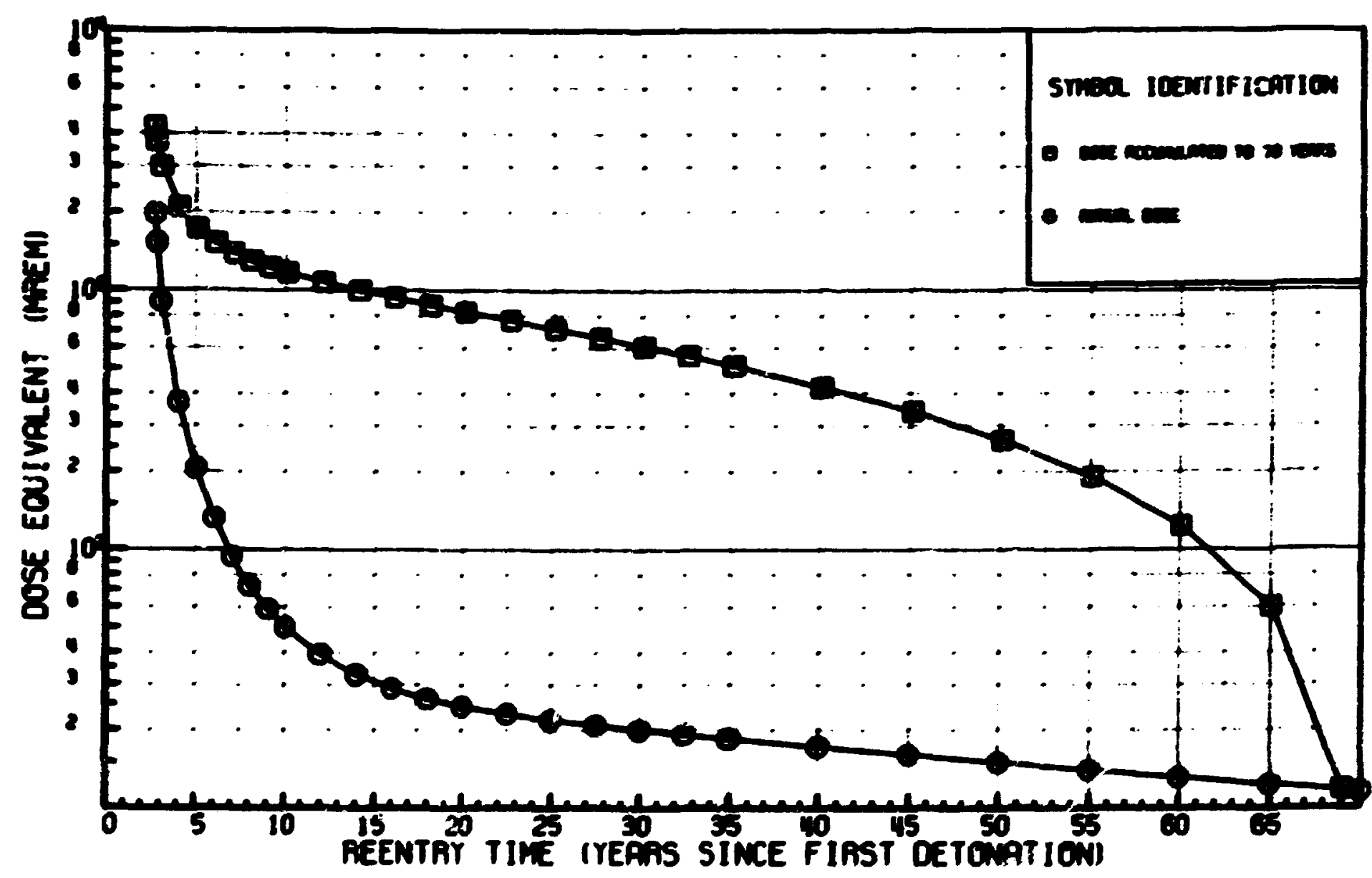

Fig. 4. Hrternal cam Dose 1 Veter above Landscape (Location 4, R10 Congo, Route 17). 


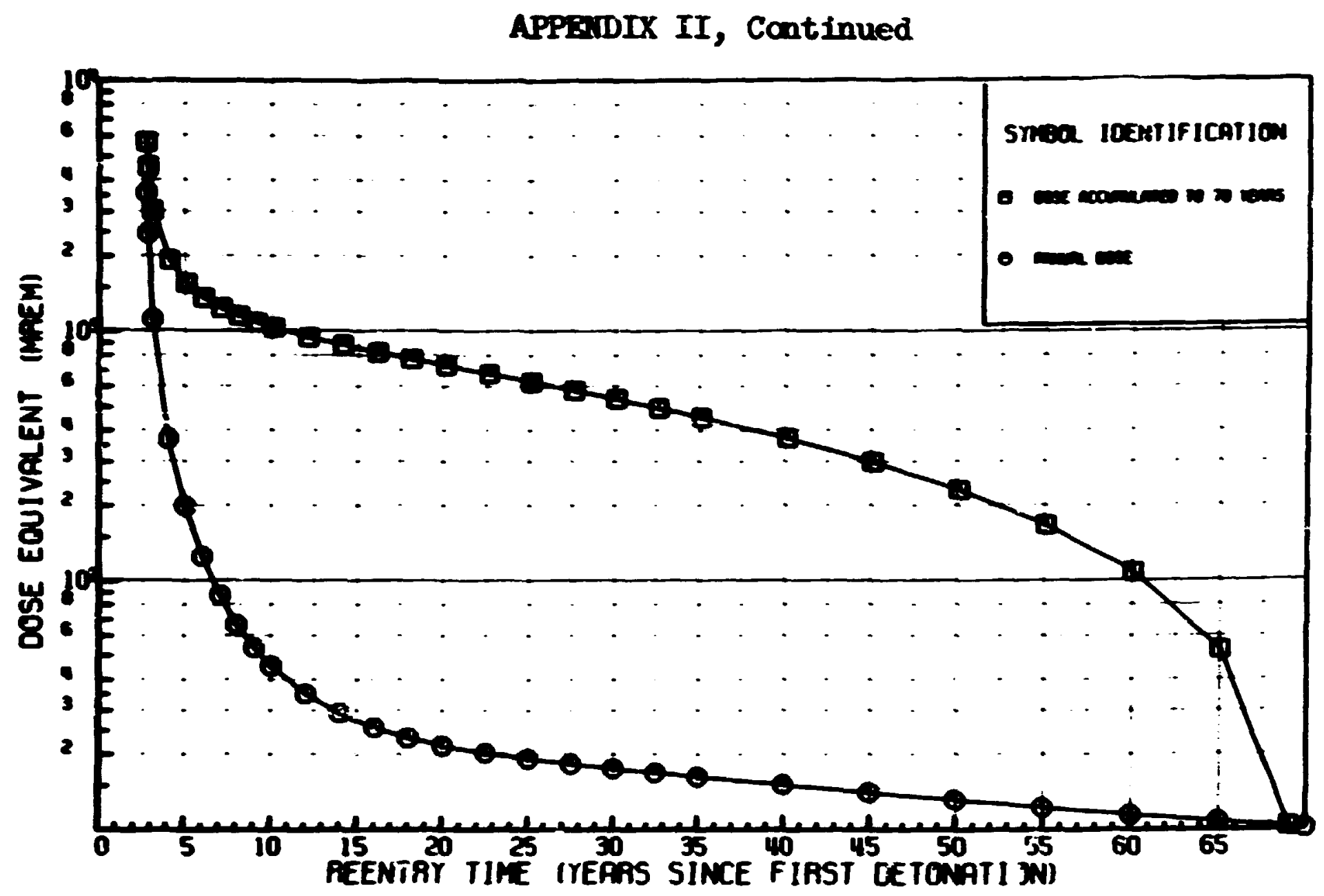

Fig. 5. Ruternal Gama Dose 1 Yeter above Landscape (Location 5, La Palma, Route 17).

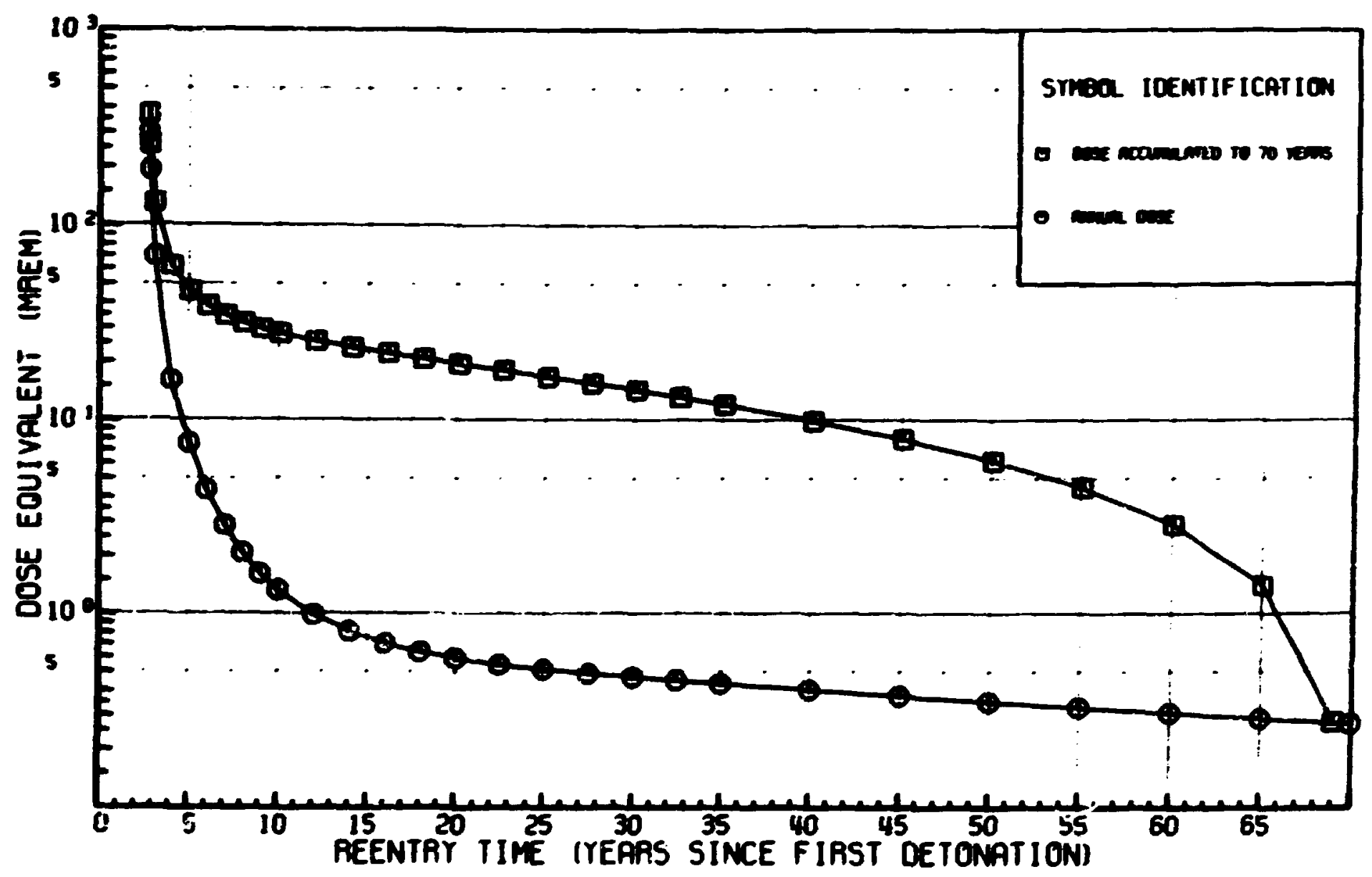

F1g. 6. External Gamm Dose 1 Meter above Landscape (Location 6, Chepigana, Route 17). 
APPBIIDIX II, Continued

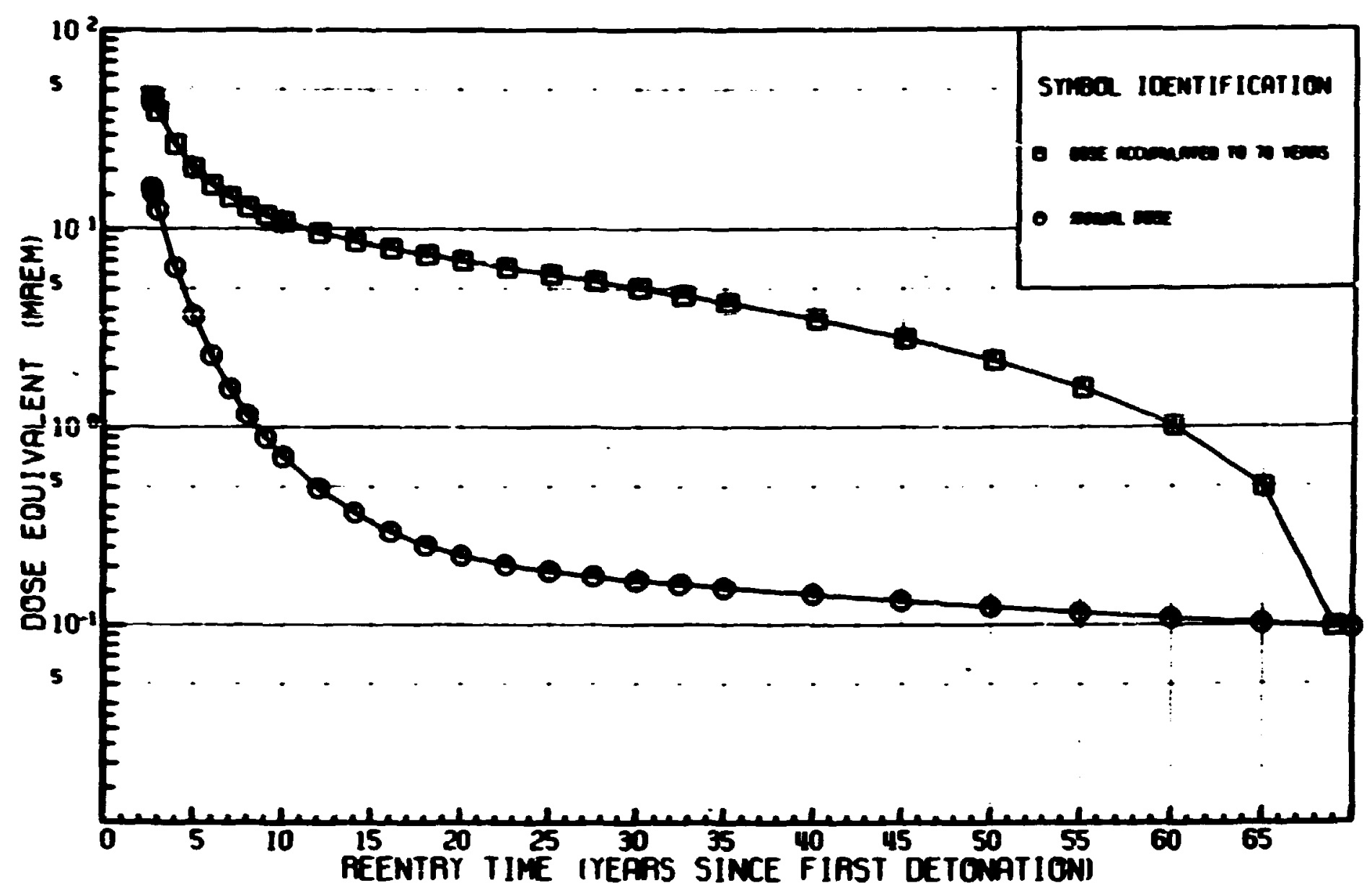

Fig. 7. External Gamma Dose 1 Meter above Iendscape (Location 7, Junction Rio Chucunaque \& Rio Chiati, Route 17).

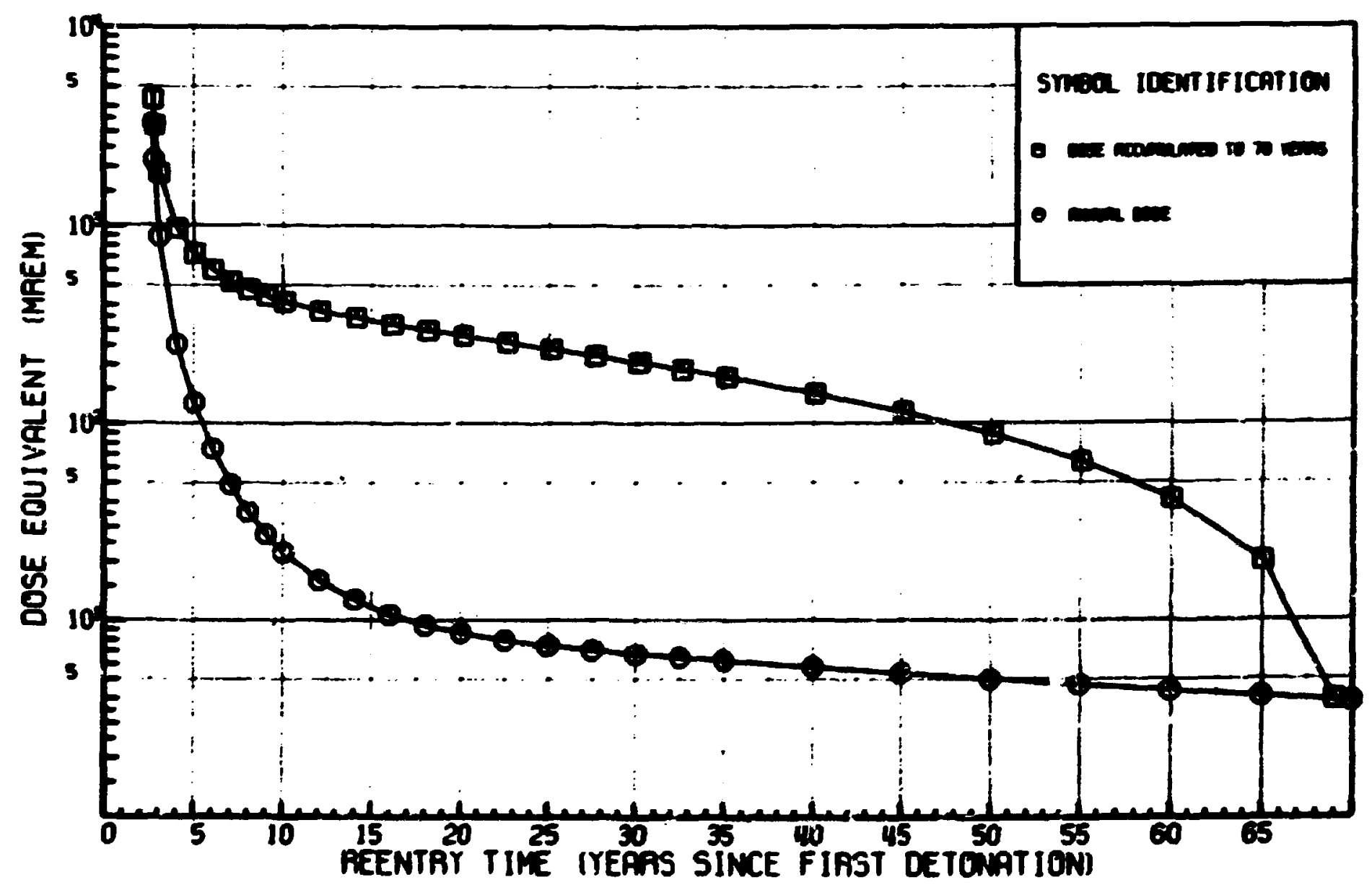

Fig. 8. Buternal Gamma Dose 1 Weter above Landscape (Location 8, Vala, Route 17). 
APPssidIX II, Continued

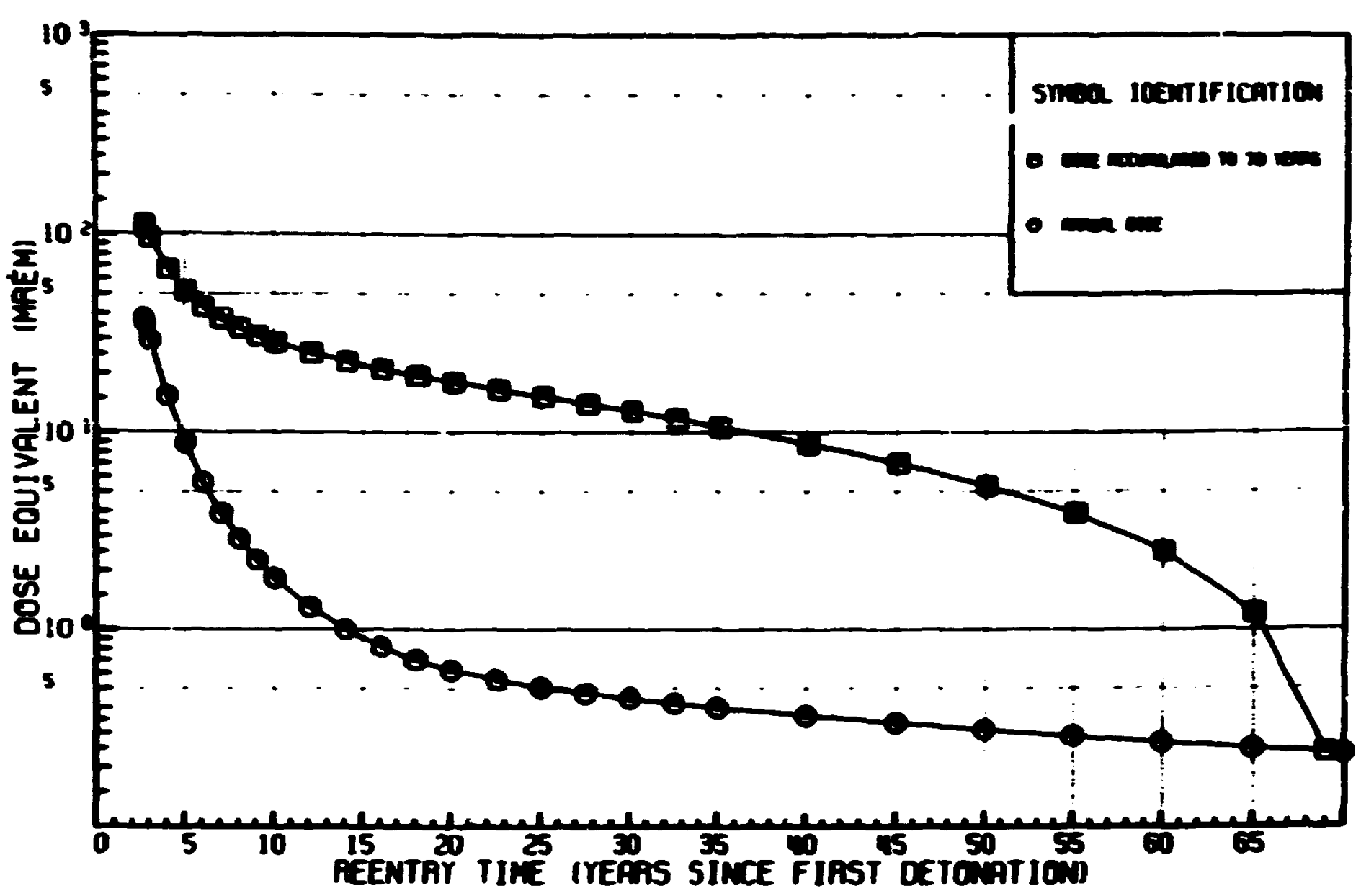

Fig. 9. Buternal Gam Dose 1 Heter above Iandscape (Location 9, Yantupo, Route 17).

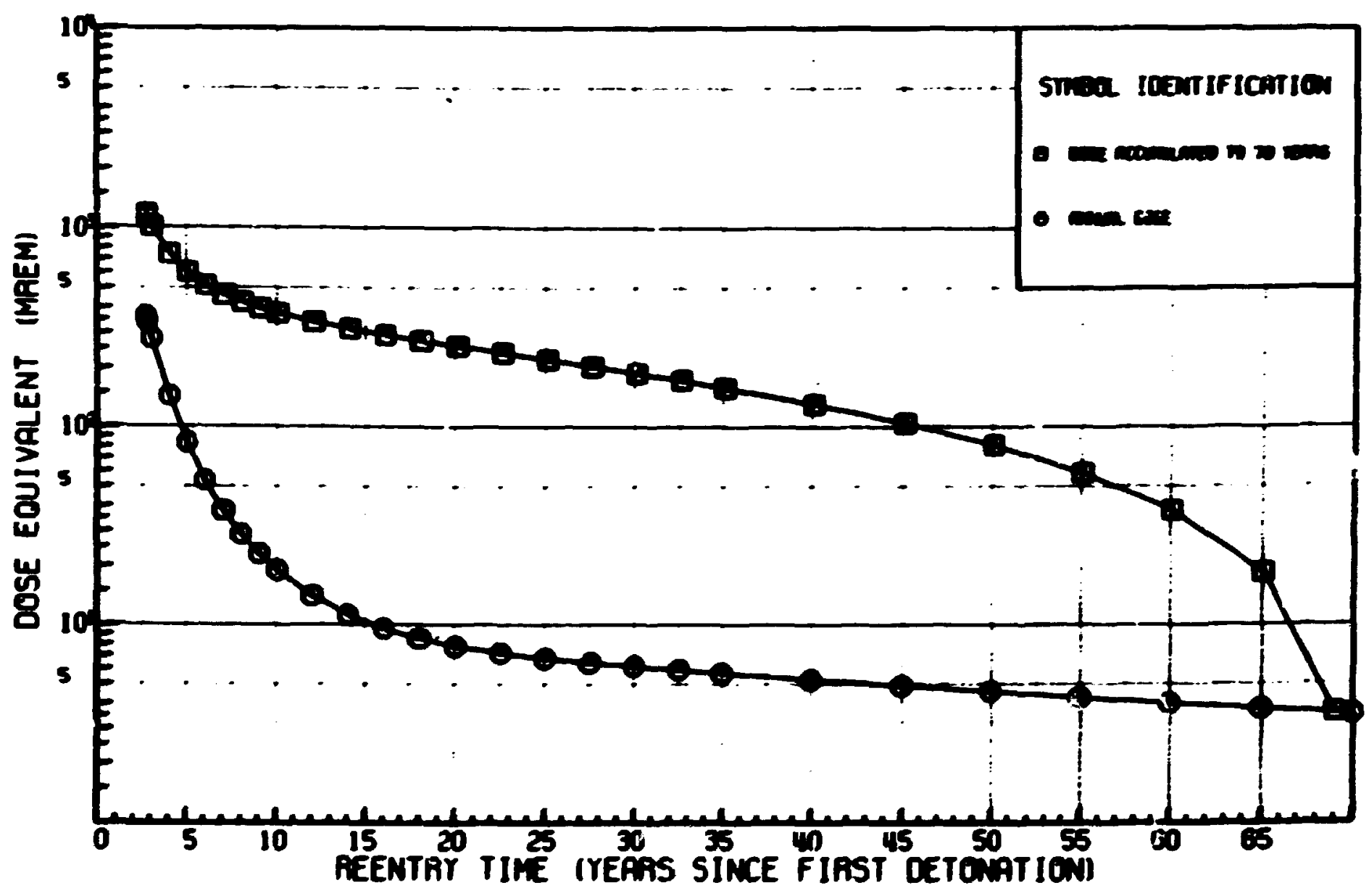

F18. 10. External Camma Dose 1 Meter above Iandscape (Iocation 10, Mulatupo, Route 17). 
AFFODDX II, Continued

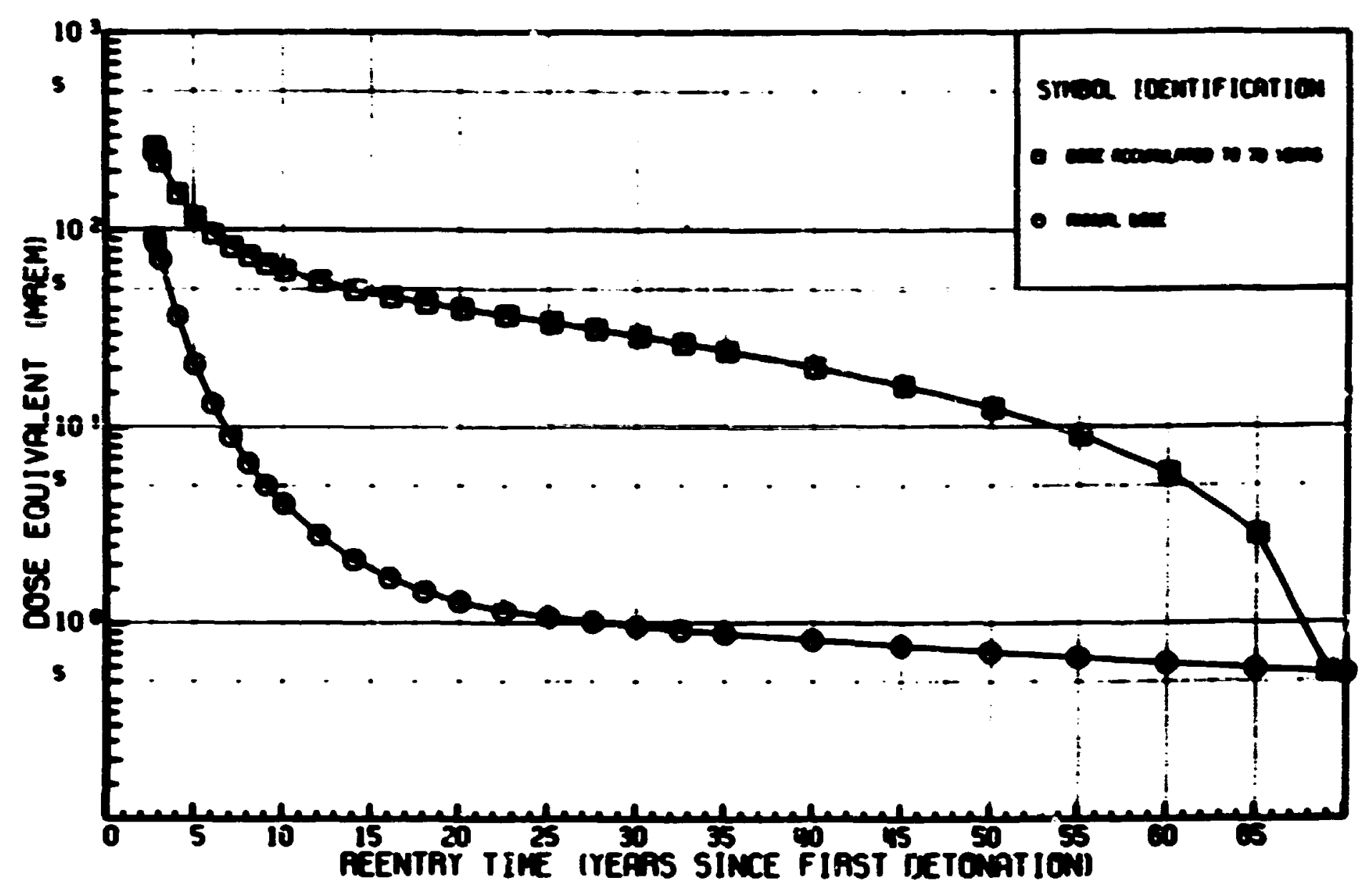

Fig. 11. Brternal Cama Dose 1 Keter above Iandscape (Location 11, Acla, Routie 17).

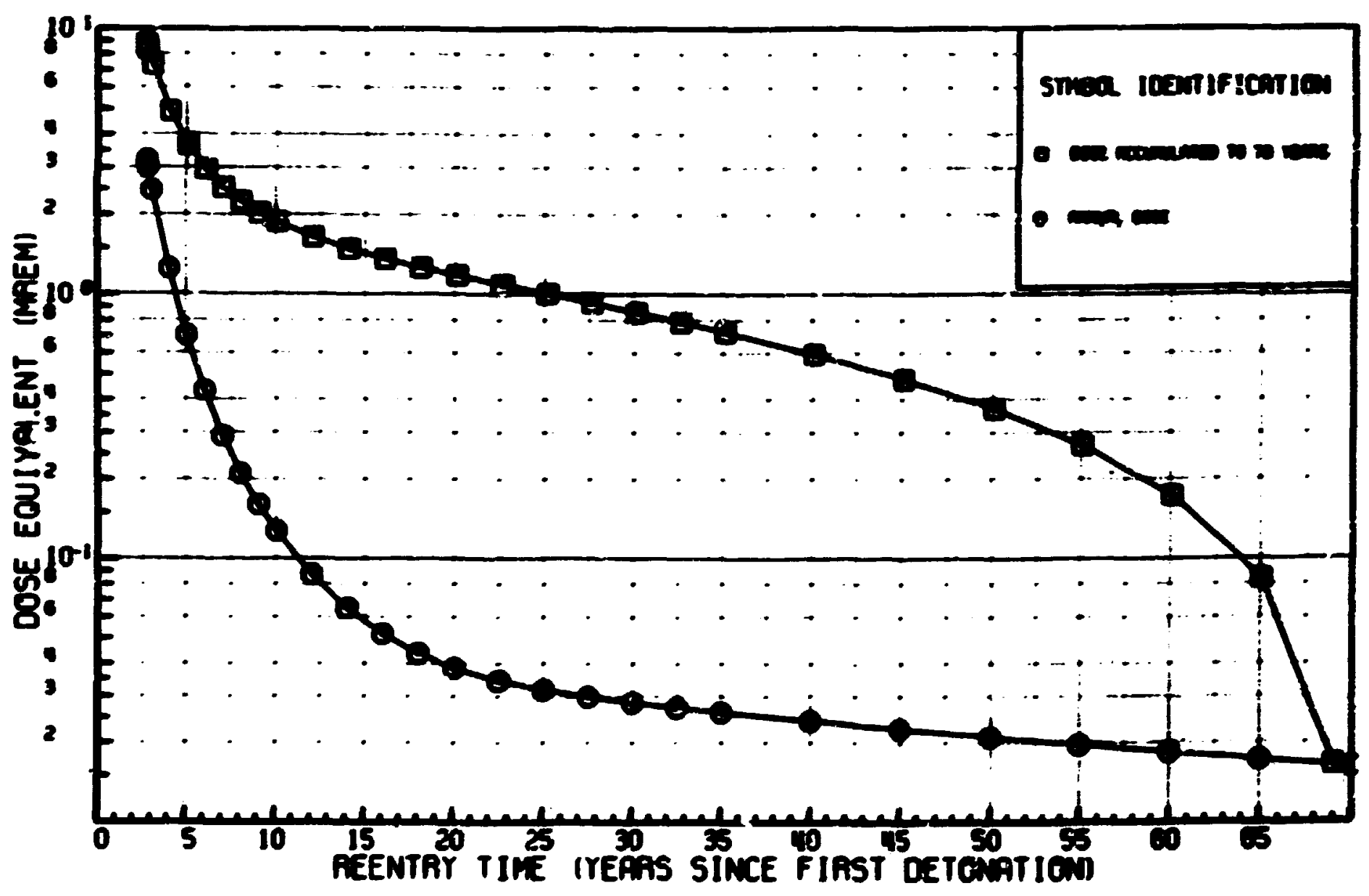

P18. 12. Bxternal Gema Dose 1 Meter above Landscape (Location 12, Sabalo, Rrsic 17). 
APPBSIDIX II, Continued

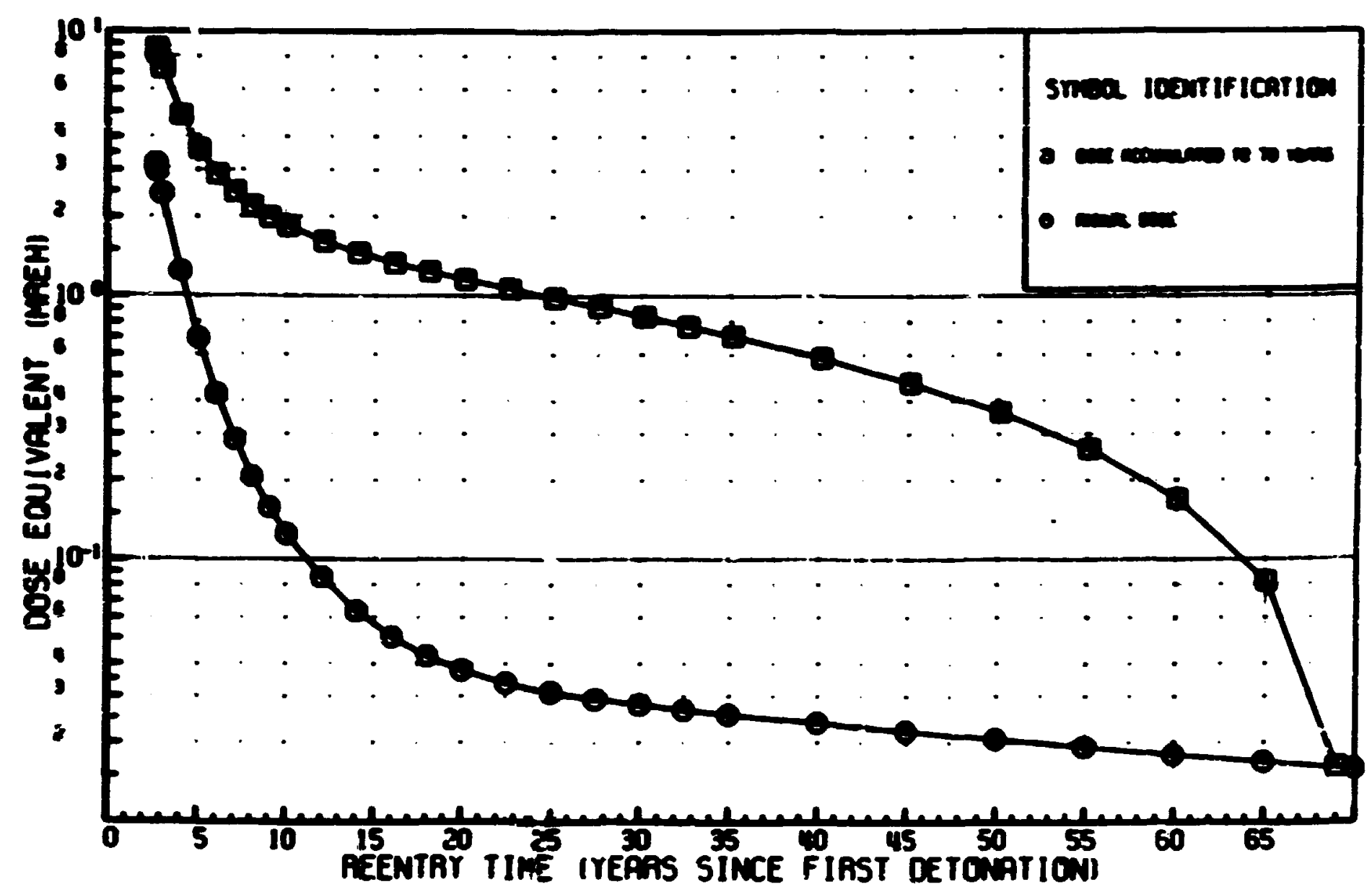

F18. 13. Bxternal sama Dose 1 Keter above Jandscafe (Location 13, Alligandi, Route 17). 

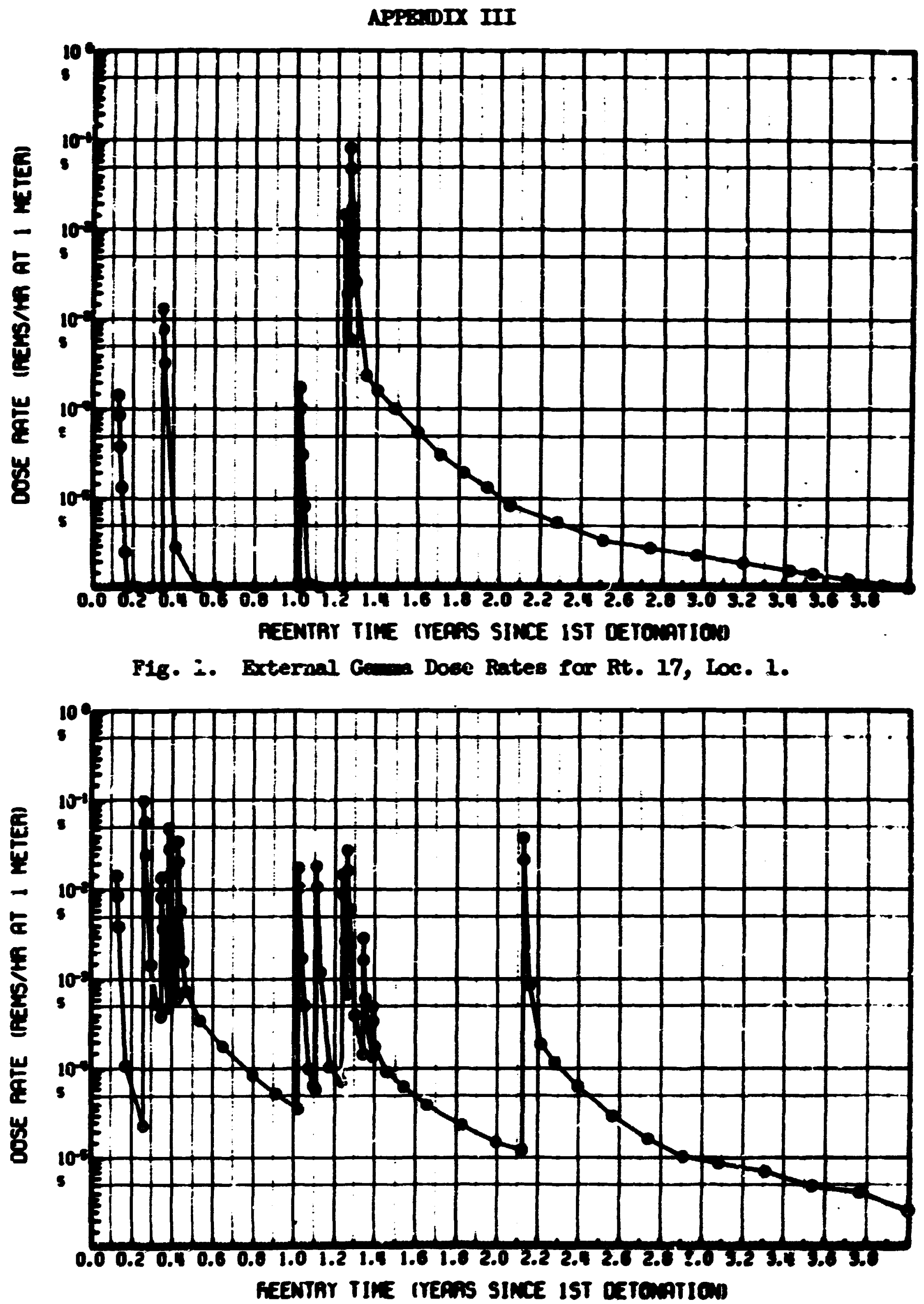

P1g. 2. External Genes $D_{r:,}$ Raten for Rt. 17, Loc. 2. 


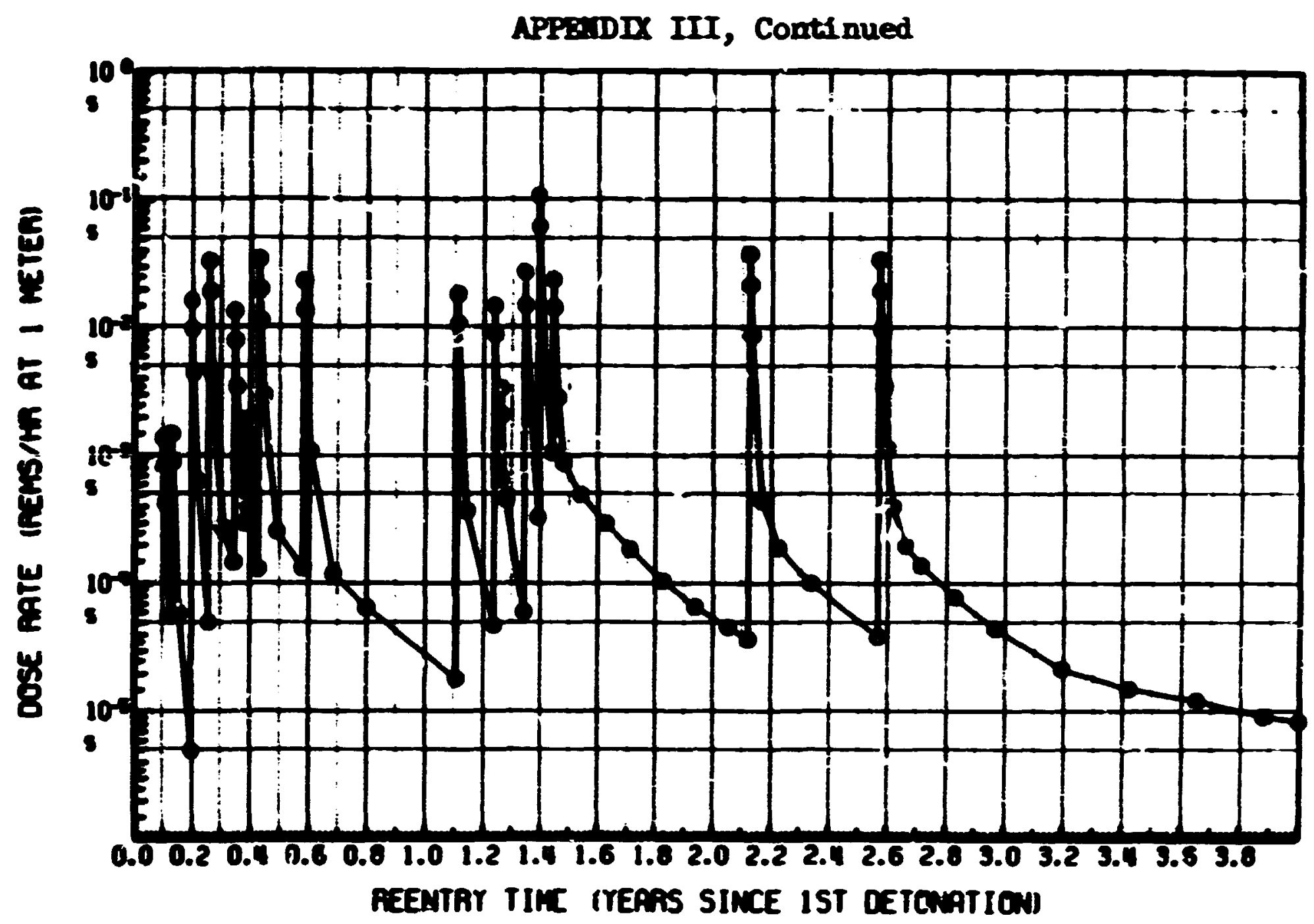

F1g. 3. Bxternal Gerase Dotes for Rt. 17, Loc. 3.

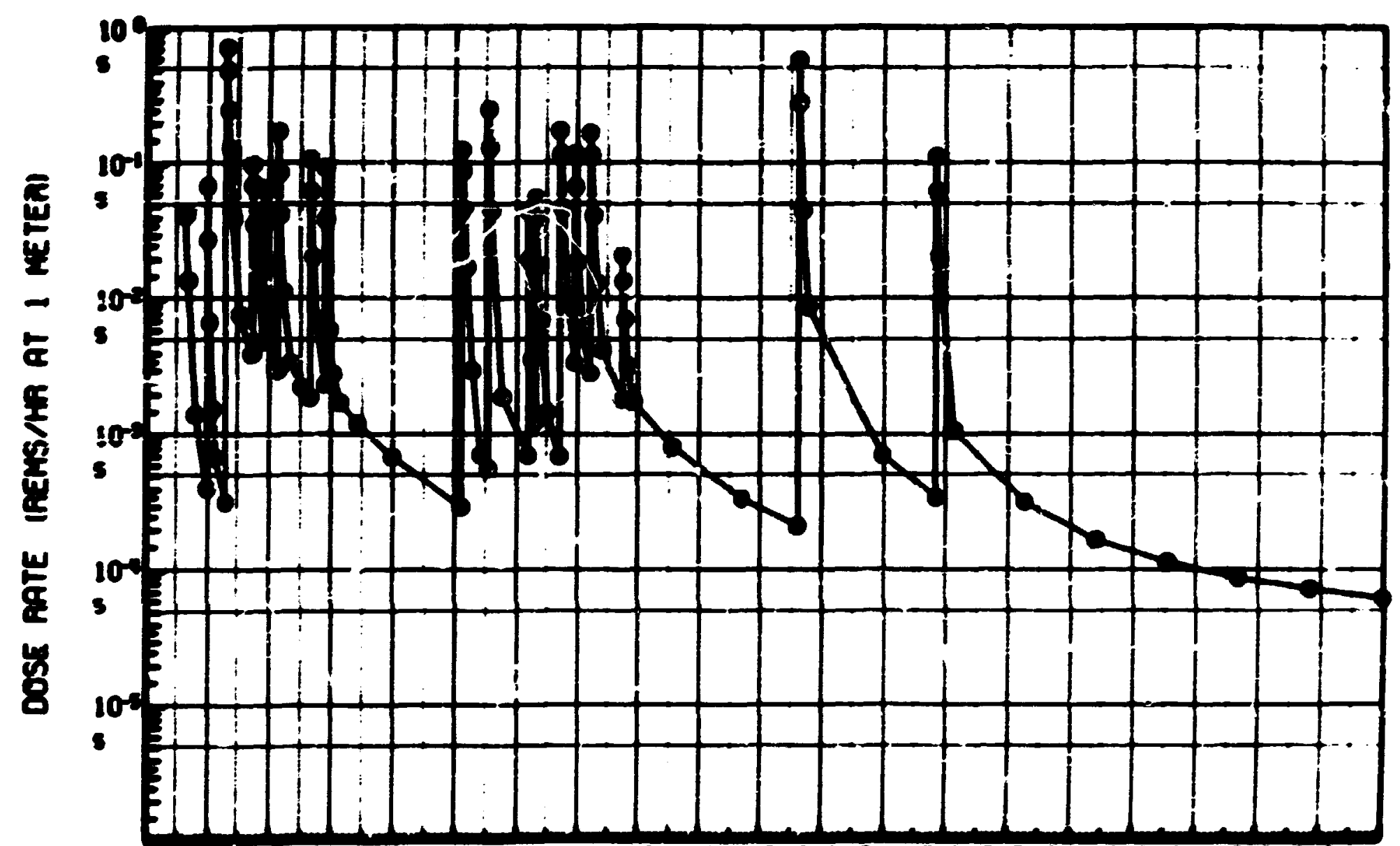

$0.00 .20 .4 \quad 0.60 .8 \quad 1.01 .21 .4 \quad 1.6 \quad 1.82 .02 .22 .42 .62 .83 .03 .23 .43 .63 .8$ FEENTRY TIME (YEAAS SINE 1ST OETONATION)

F1g. 4. External Gam Dose Rates for Rt. 17, Loc. 4. 


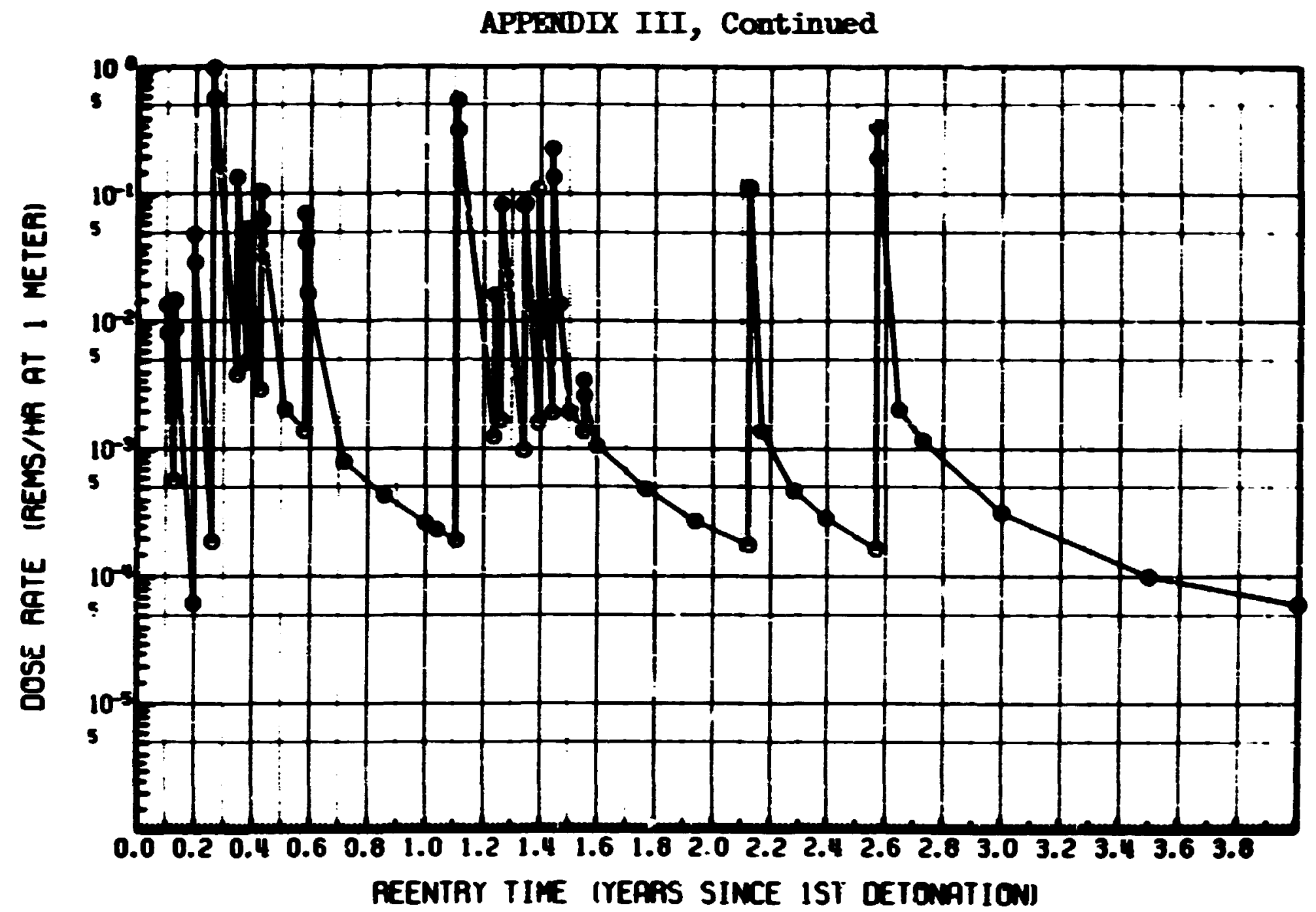

Fig. 5. Bxternal Gemma Dose Rates for Rt. 17, Loc. 5.

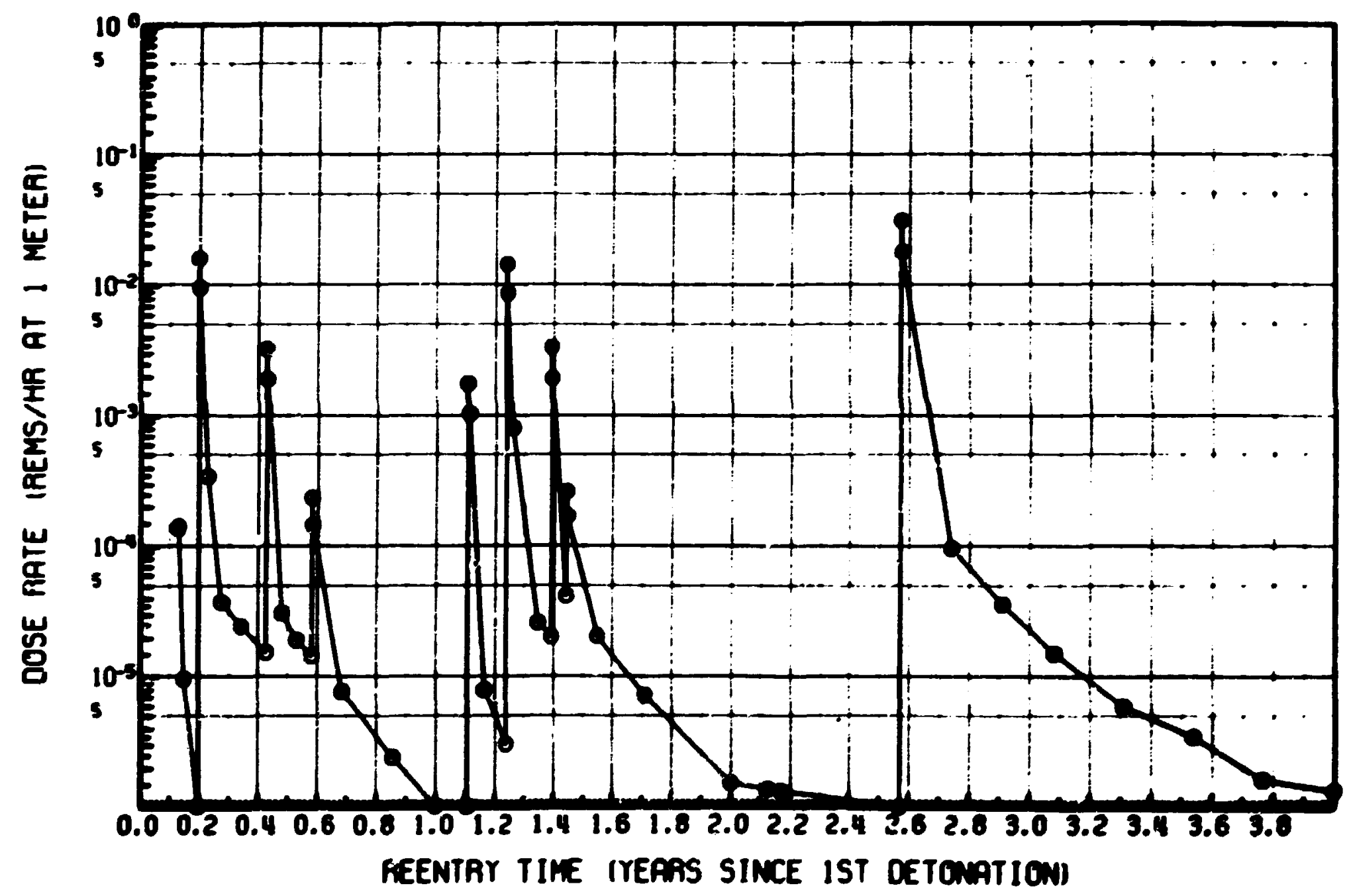

P1g. 6. Bxternal Gama Dose Rates for Rt. 17, Loc. 6. 
APPENDIX III, Continued

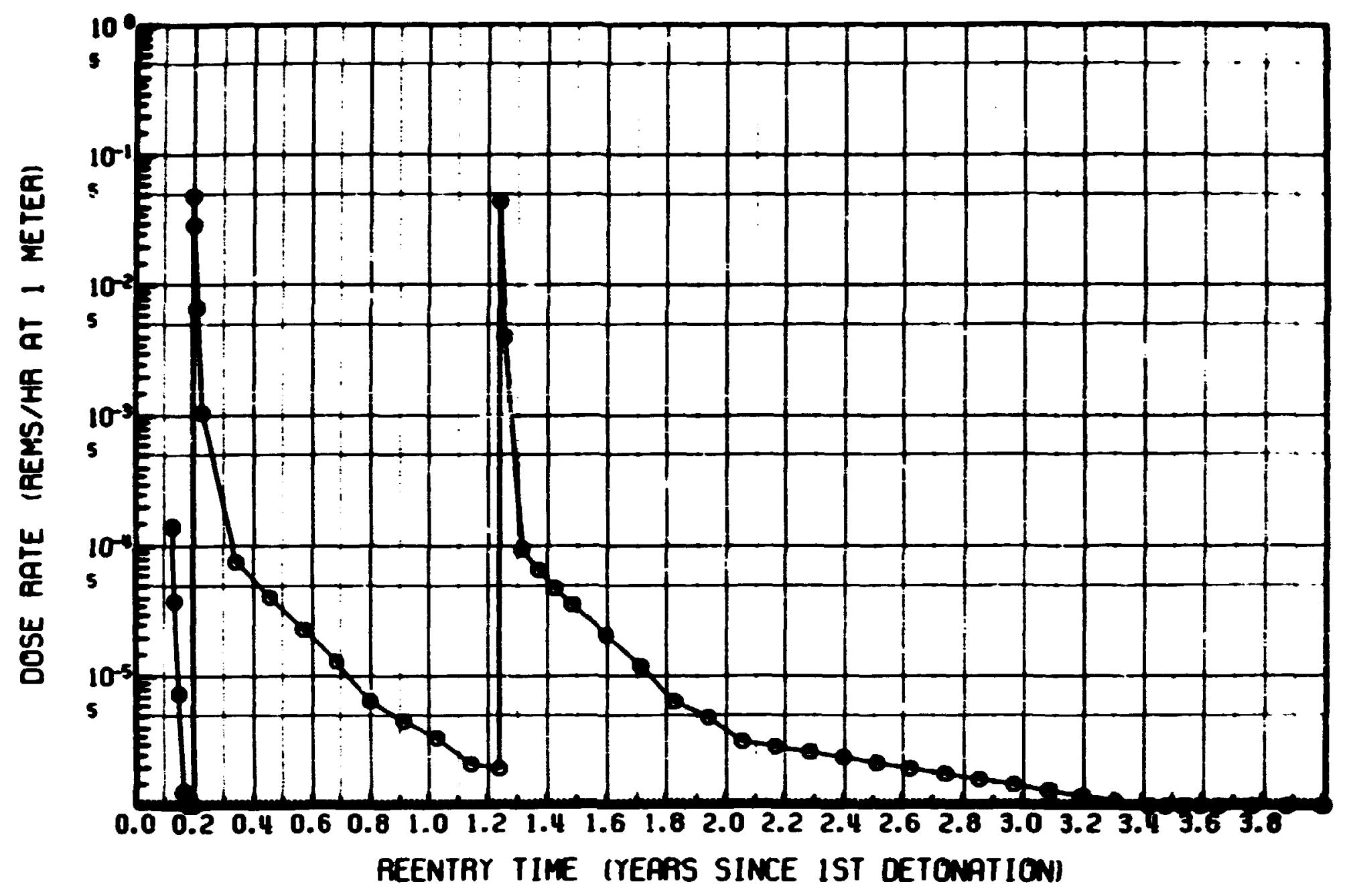

Fig. 7. External Gamma Dose Rates for Rt. 17, Loc. 7.

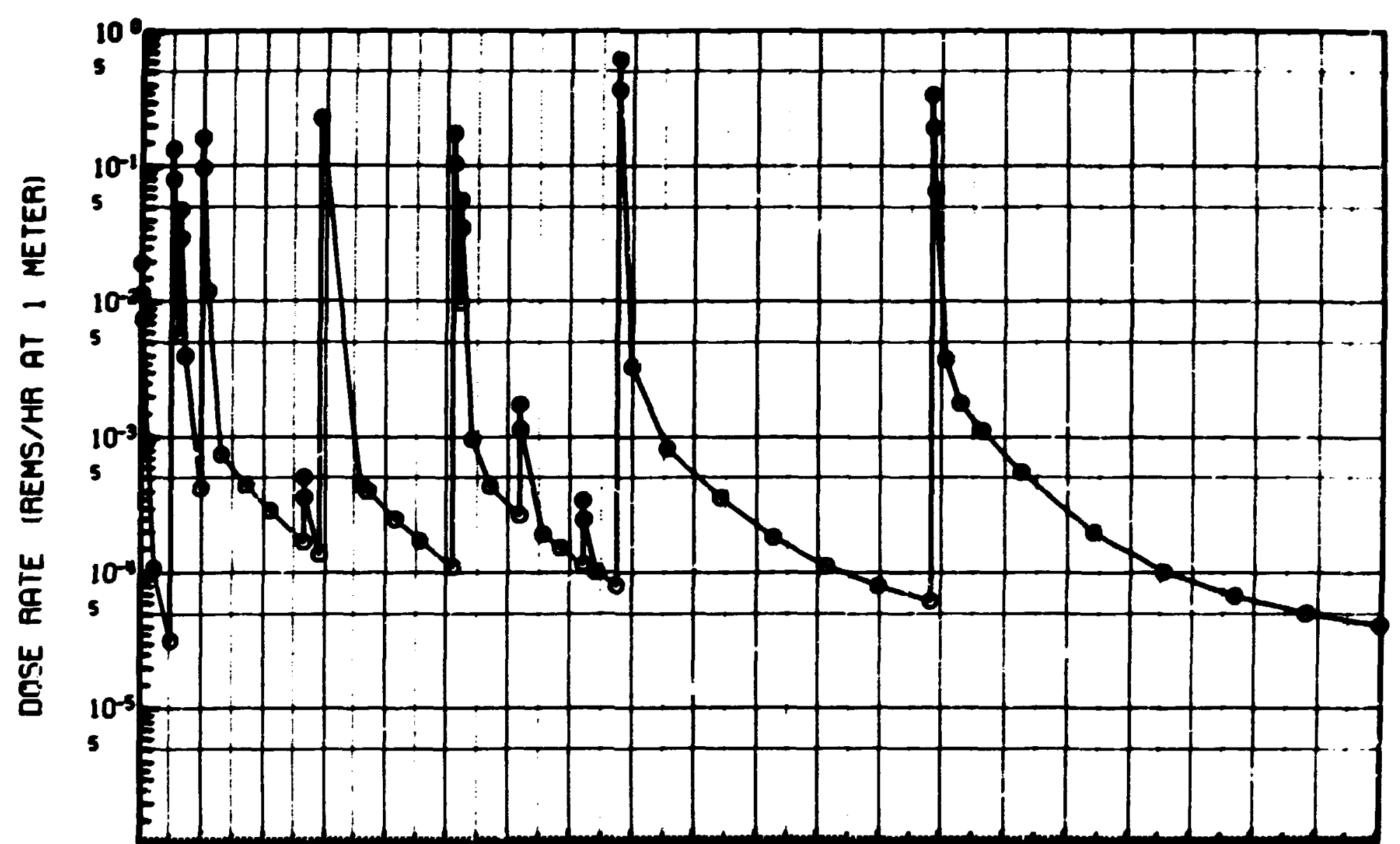

$\begin{array}{lllllllllllllllllllllll}0.0 & 0.2 & 0.4 & 0.6 & 0.8 & 1.0 & 1.2 & 1.4 & 1.6 & 1.8 & 2.0 & 2.2 & 2.4 & 2.6 & 2.8 & 3.0 & 3.2 & 3.4 & 3.6 & 3.8\end{array}$ REENTRY TIME (YEAFIS SINCE IST DETONATION)

Fig. 8. External Gamma Dose Rates for Rt. 17, Loc. 8. 
APPENDIX III, Continued

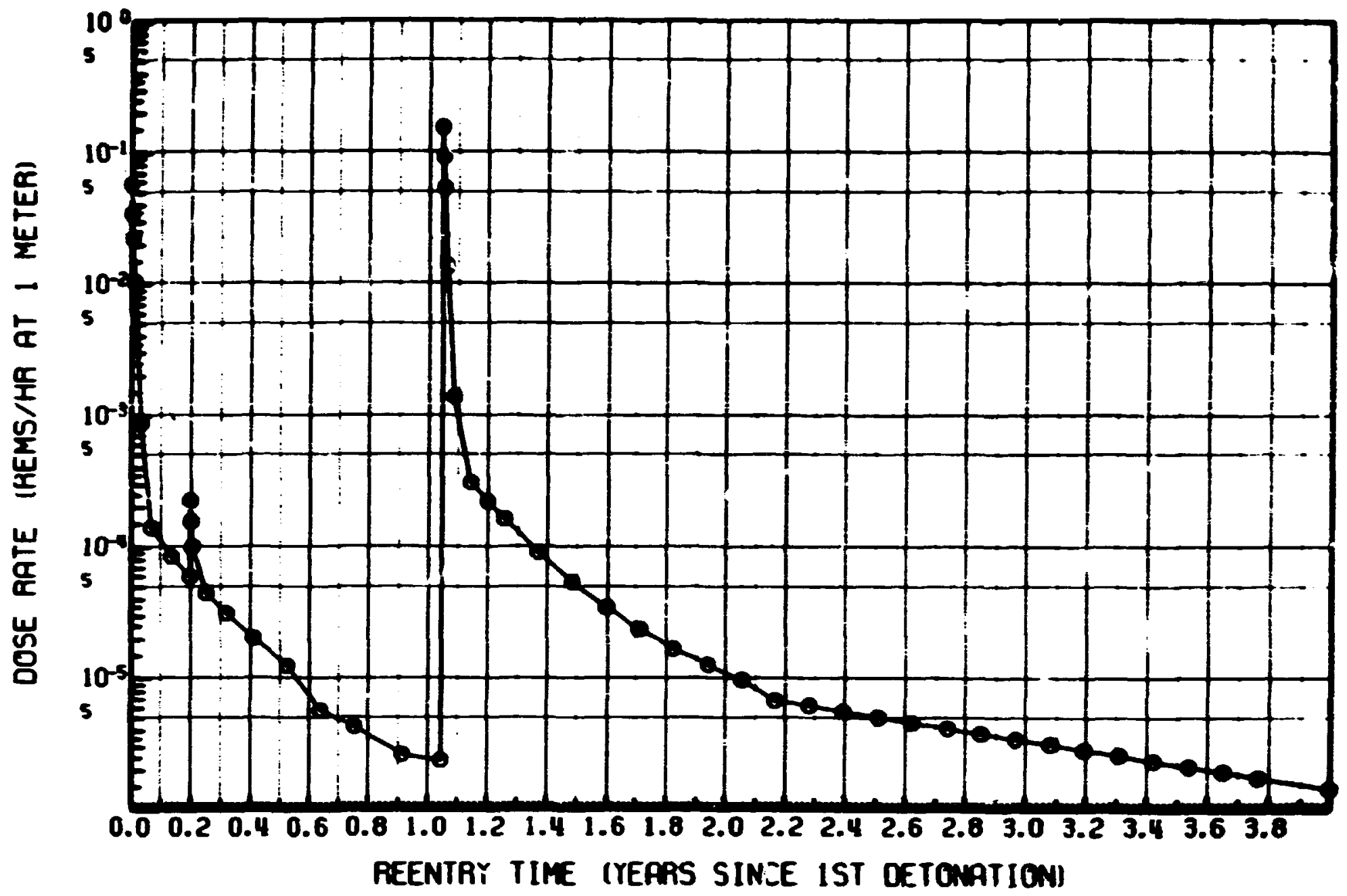

Fig. 9. External Gamma Dose Rates for R;. 17, Loc. $\ni$.

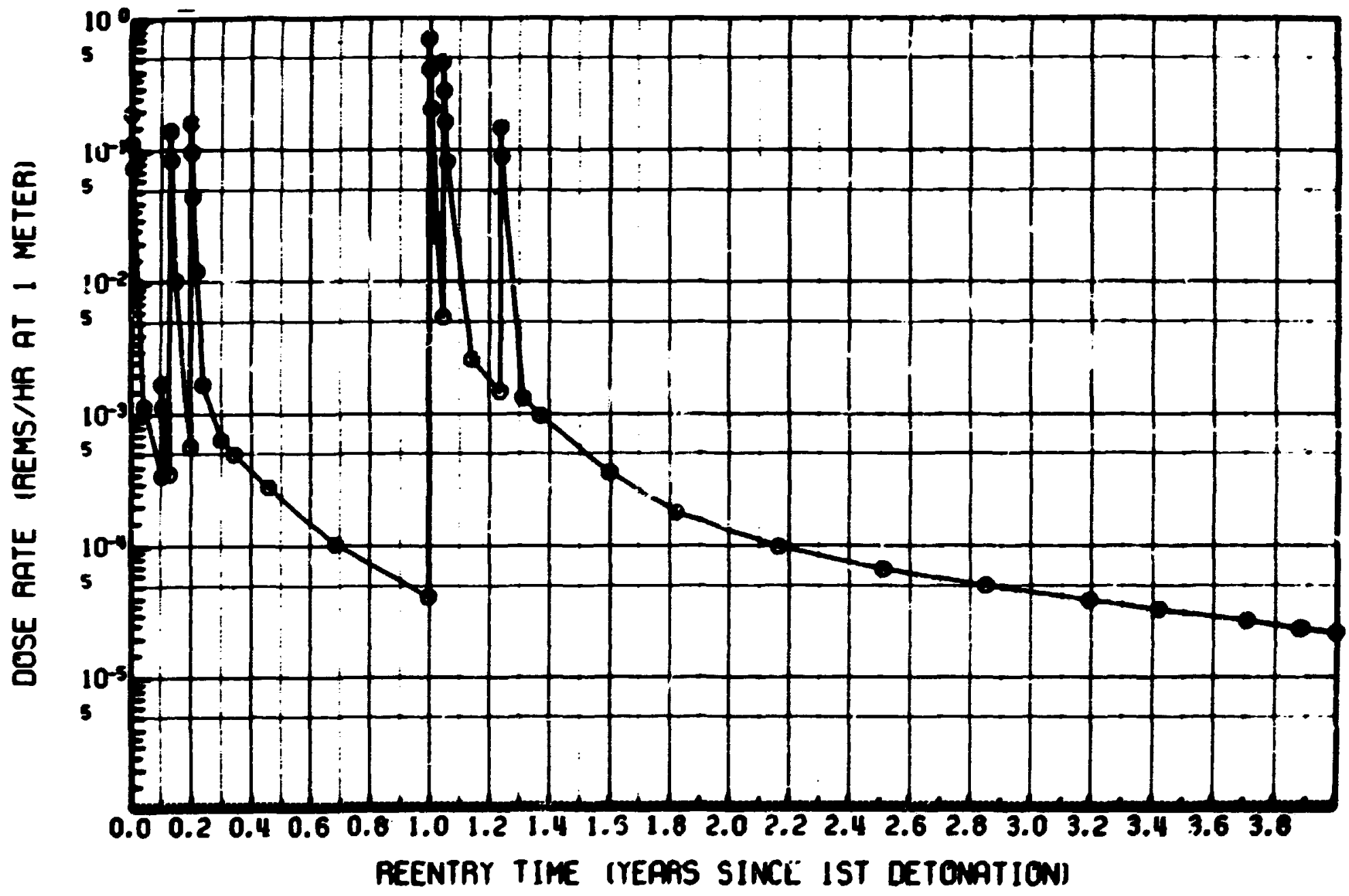

F1g. 10. External Game Dose Rates For Rt. 17, Loc. 10. 
A.PPEIDIX III, Ccatinued

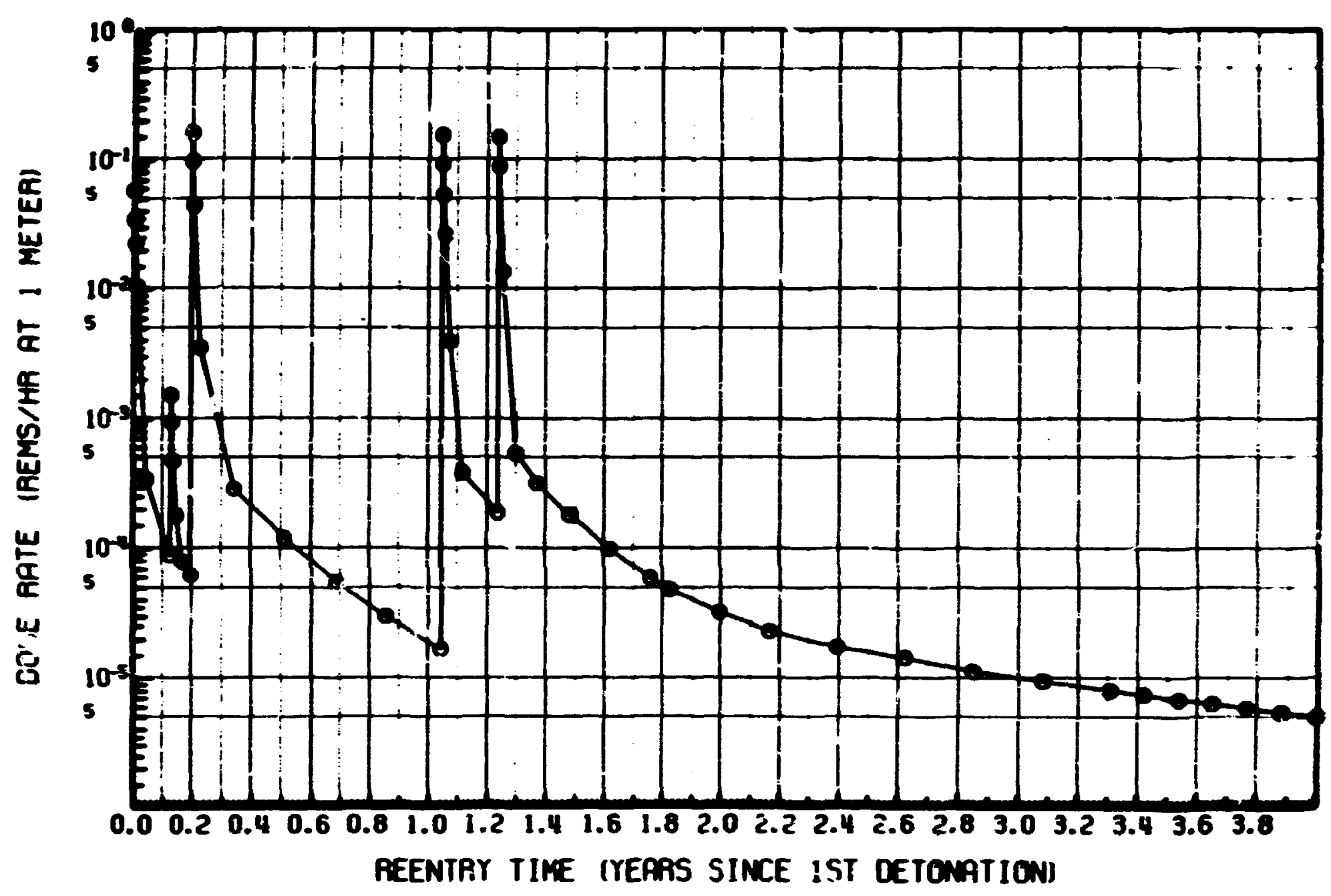

Fig. 11. External Gamma Dose Rates for ist. 17, Loc. 11.

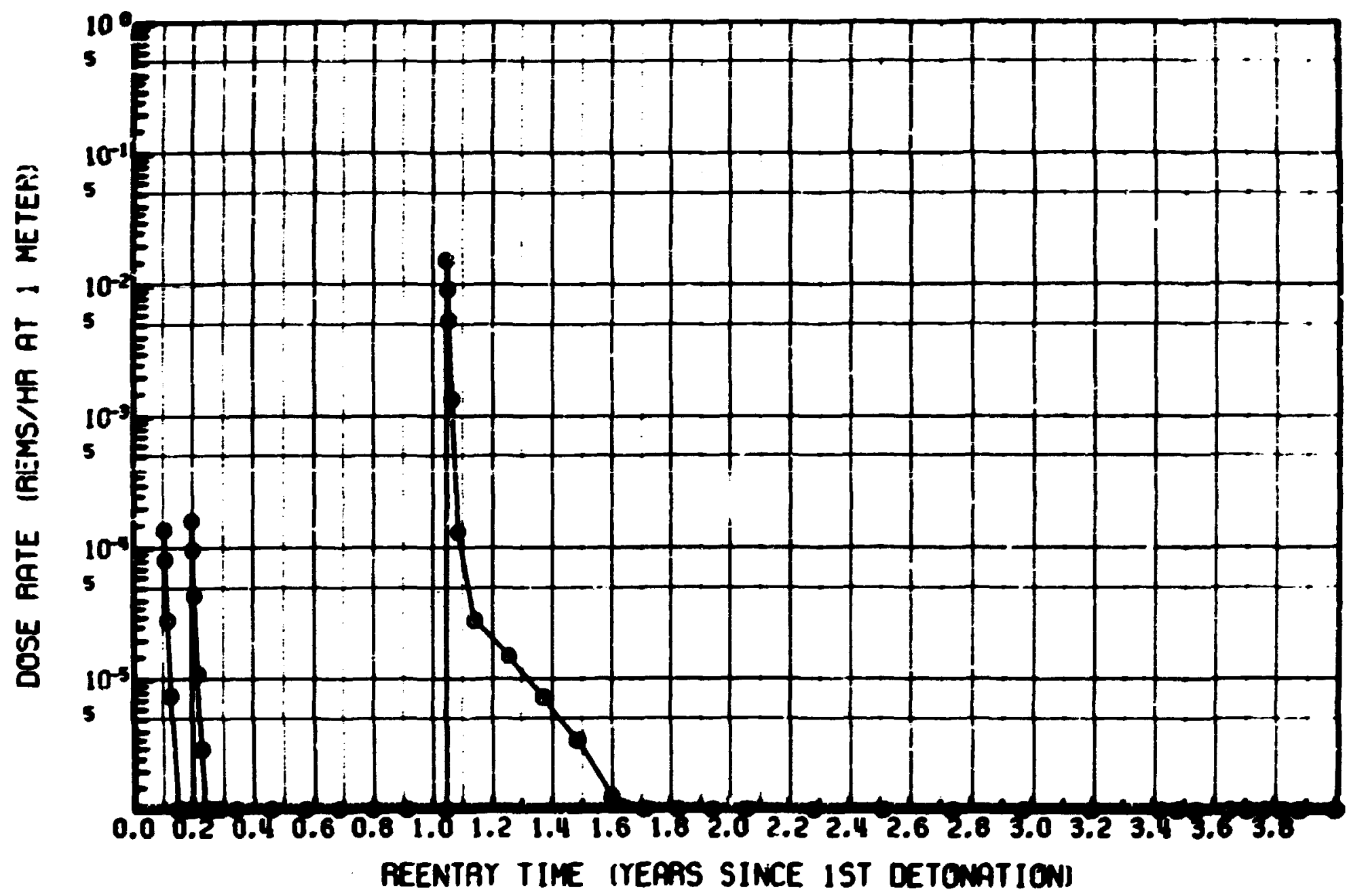

Fig. 12. External Gamma Dose Rates for Rt. 17, Loc. 12. 
APPEirDIX III, Continuec

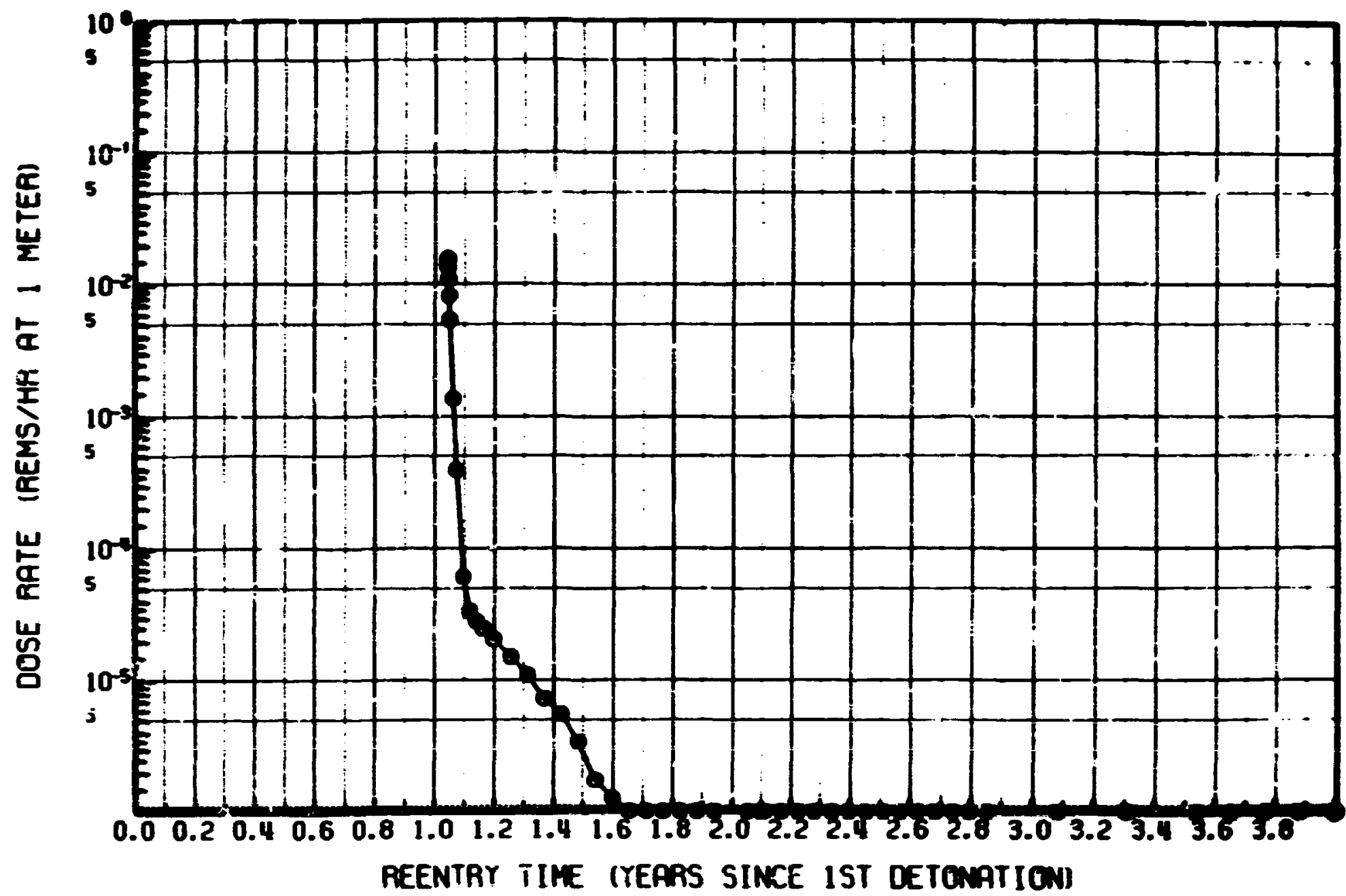

Fig. 13. External Gamma Dose Rates for Rt. 17, Loc. 13. 
APPETIDIX IV

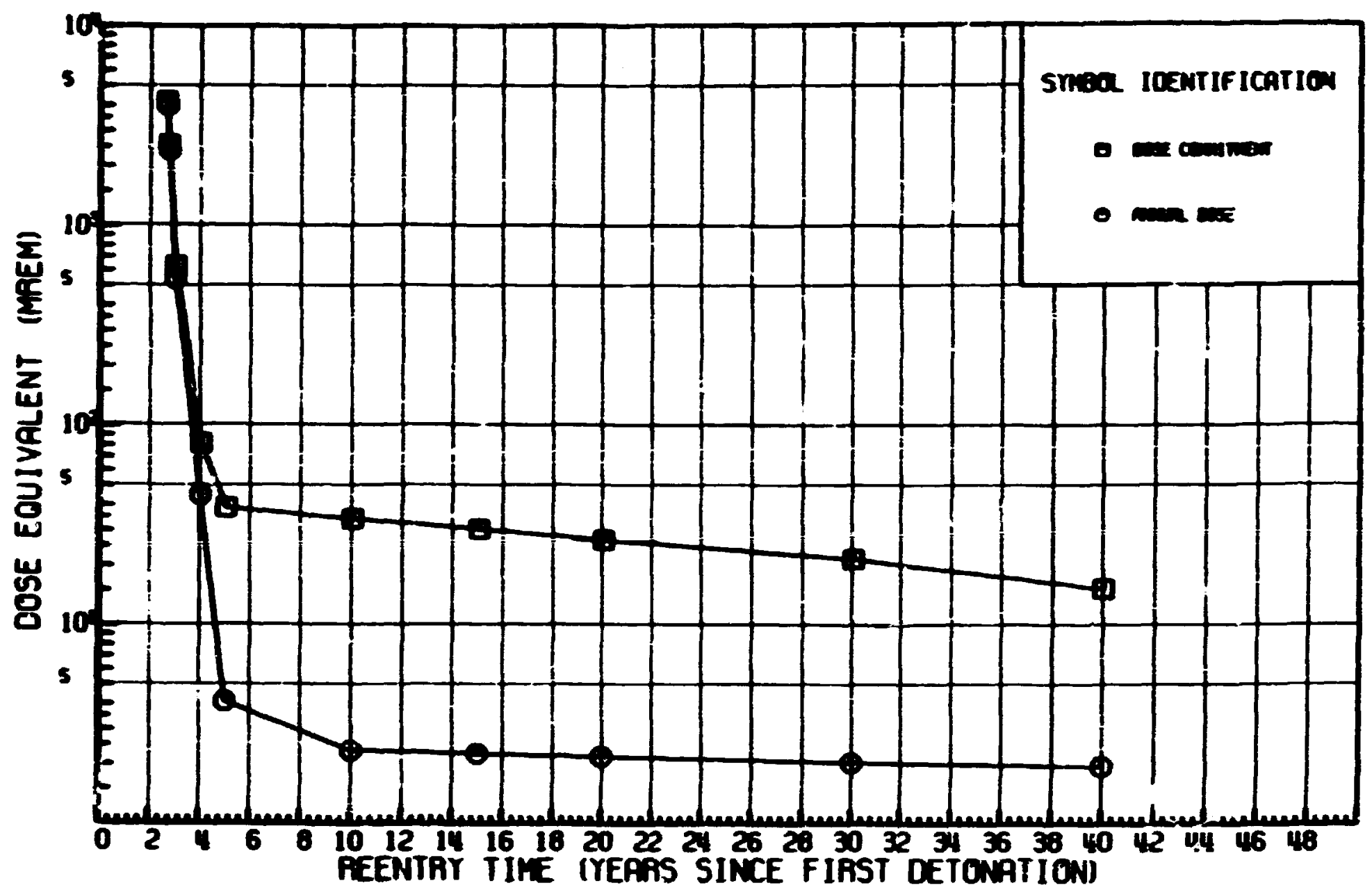

Fig. 1. Maximm internal Dose Resulting from Radionuclide Iagestion (Kidneys, Watershed 5, Route 17).

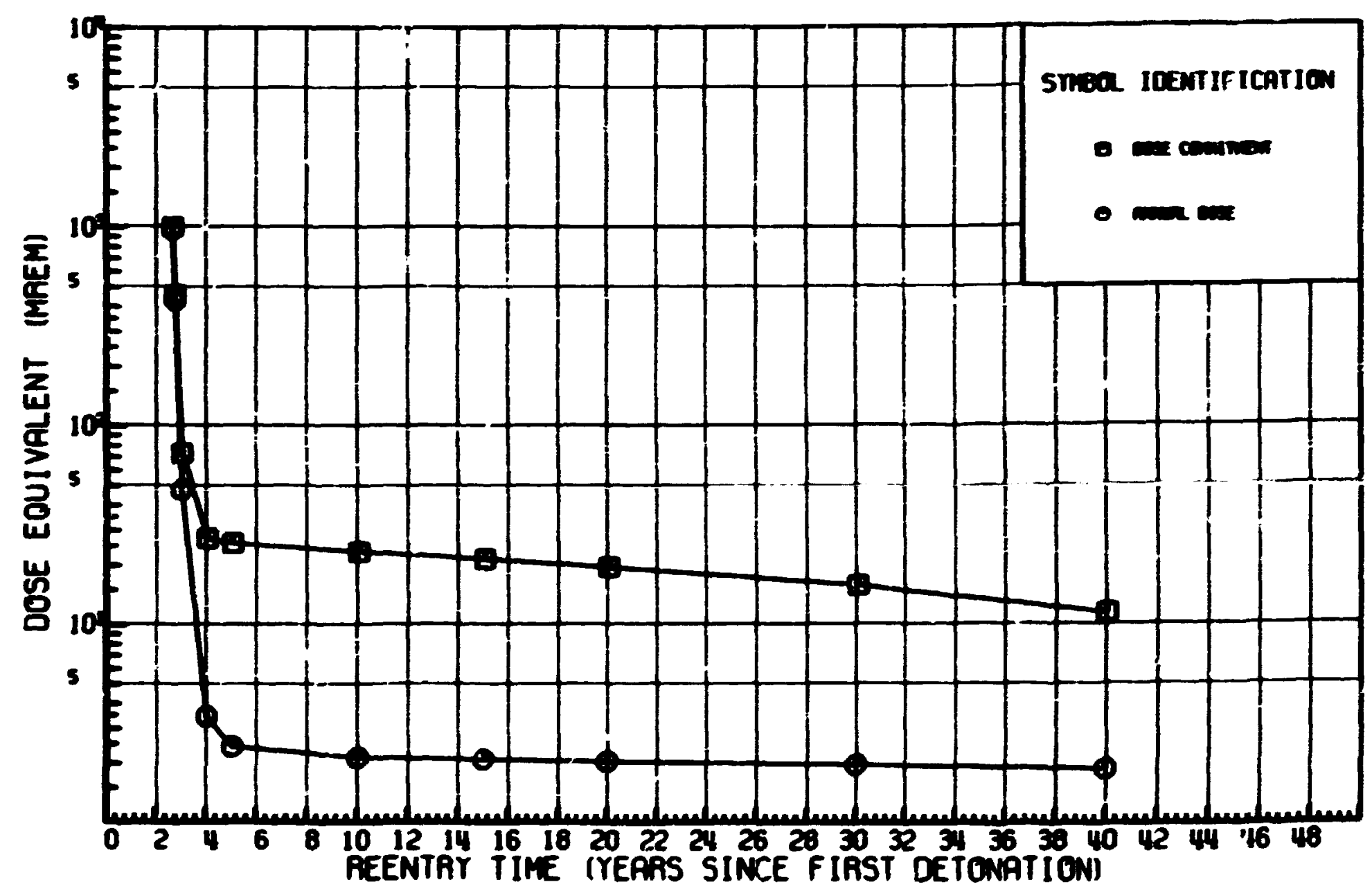

Fig. 2. Maximm Internal Dose Resulting from Radfonuclide Ingestion (Total Body, Watershed 5, Route 17). 
APPBSTDIX IV, Continued

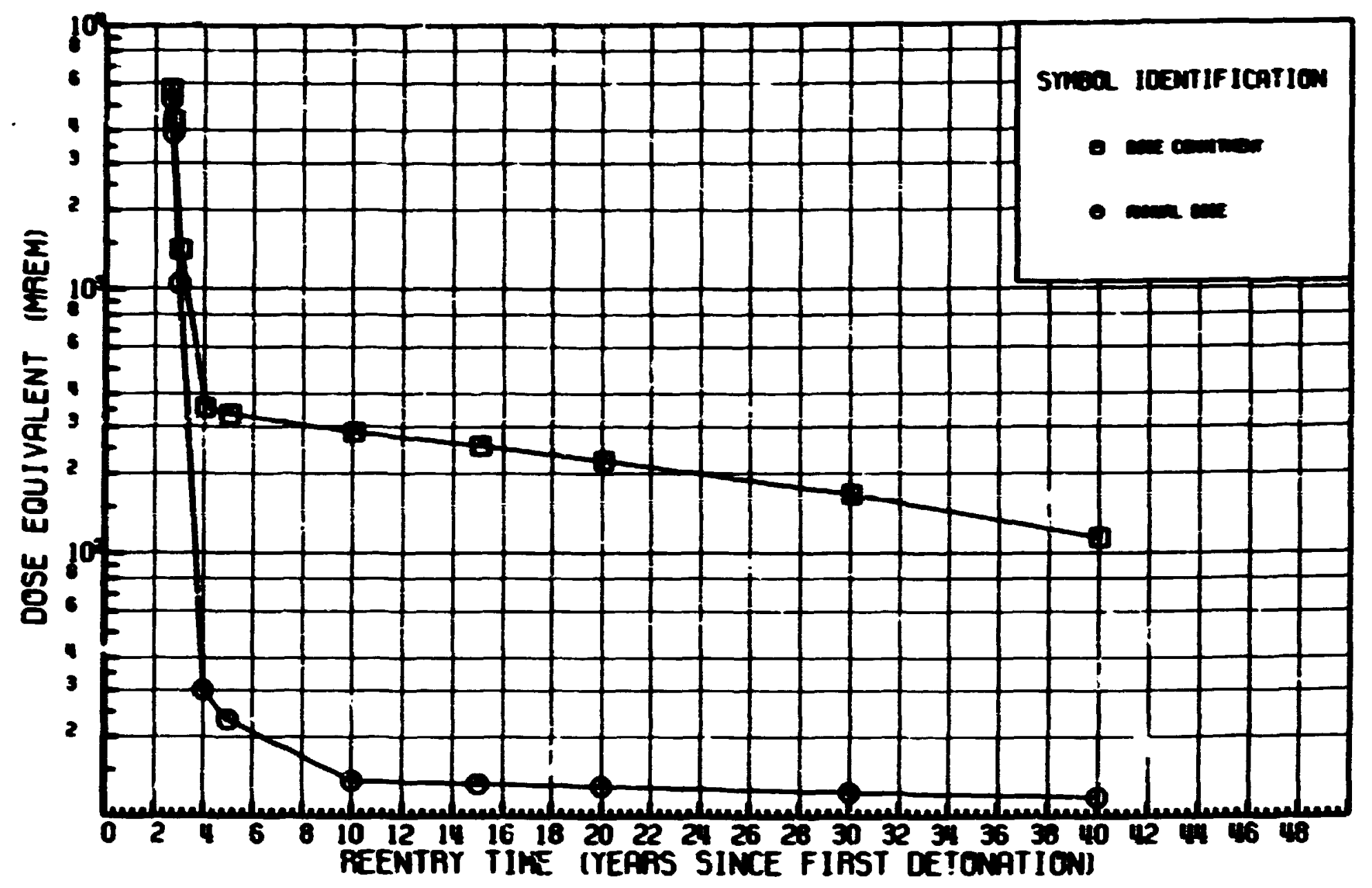

F1g. 3. Maximum Internal Dose Resulting from Radionuclide Ingestion (Bone, Watershed 5, Route 17).

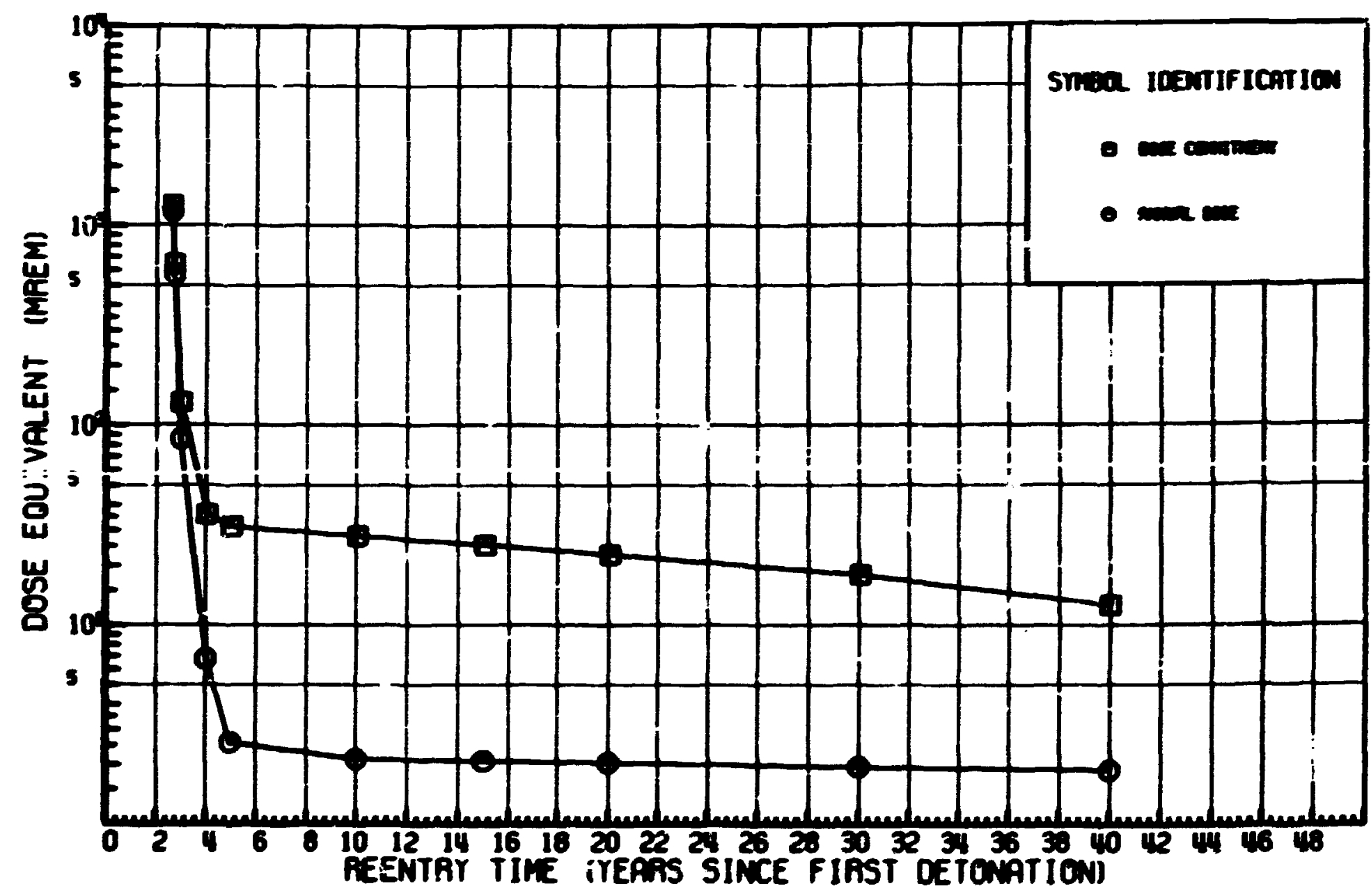

Fig. 4. Maximum Internal Dace Resulting frcm Radionuclide Ingestion (Iiver, Watershed 5, Route 17). 
APPERIIIX IV, Continued

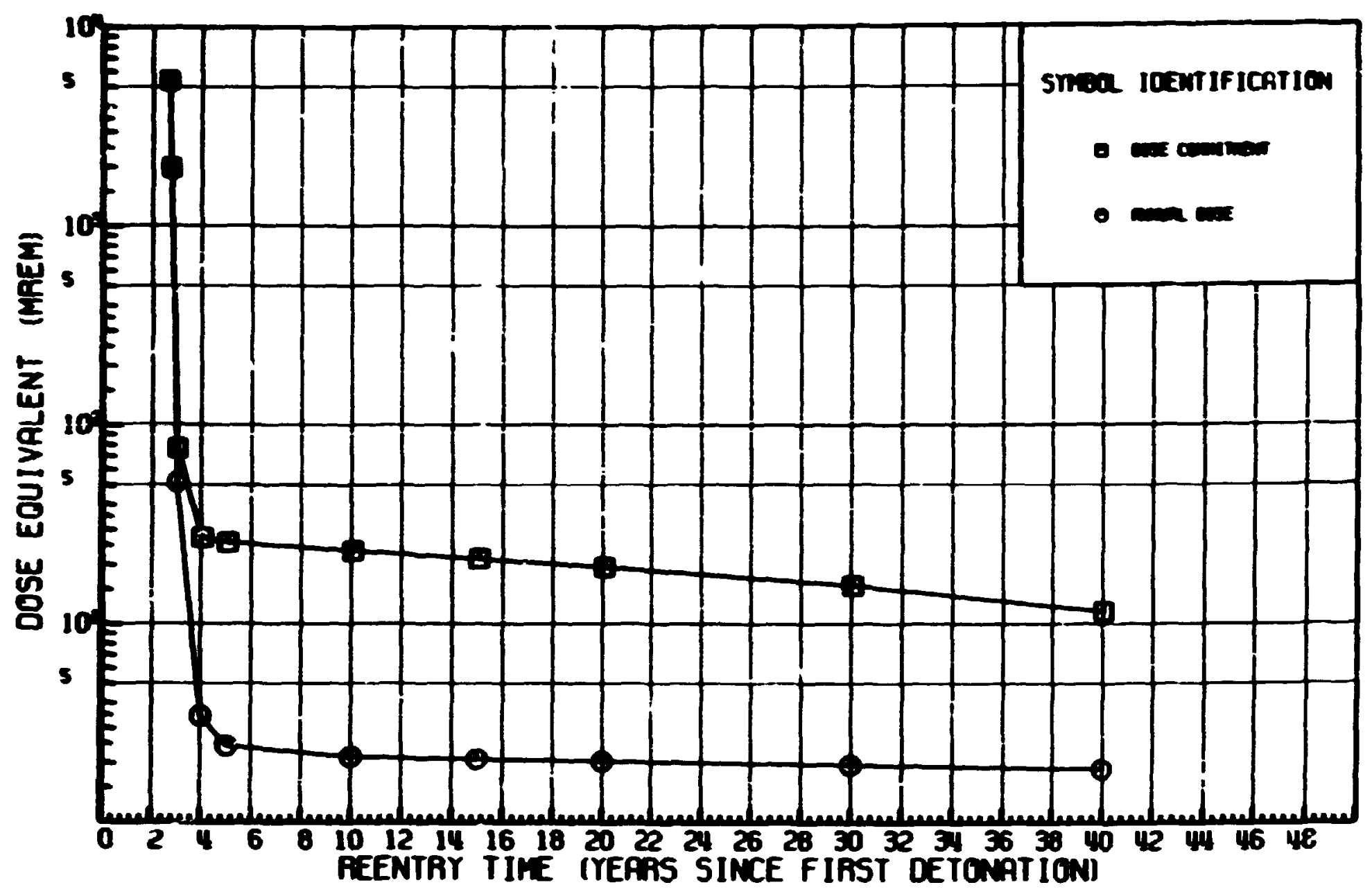

Fig. 5. Maximm Internal Dose Resulting Pran Radionuclide Ingestion (Thyroid, Hatershed 5, Route 17).

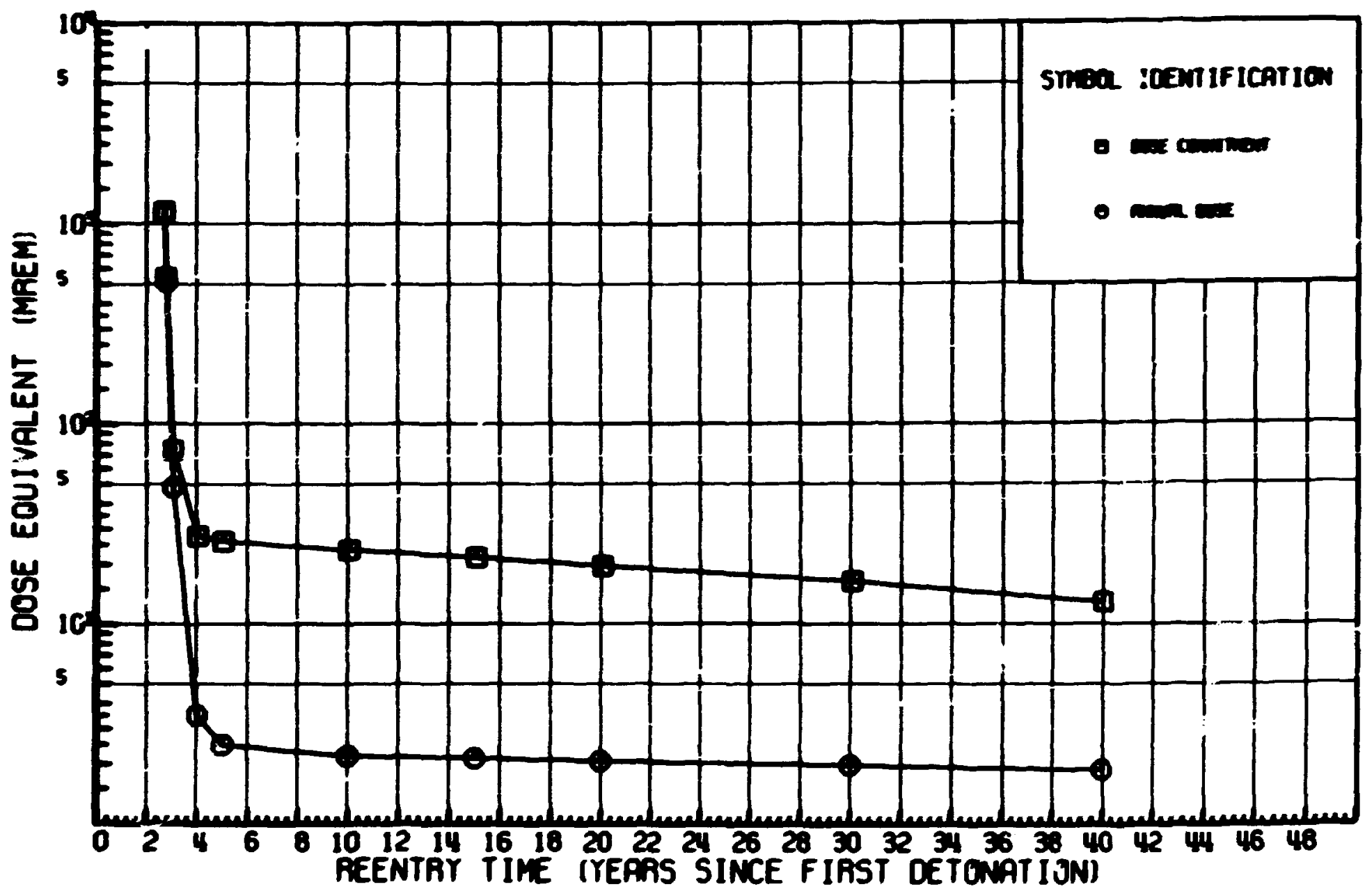

Fig. 6. Maximm Internal Dose Resulting fran Radionuclide Ingestion (Testes, Hatersied 5, Route 17). 
APPENDIX IV, Continued

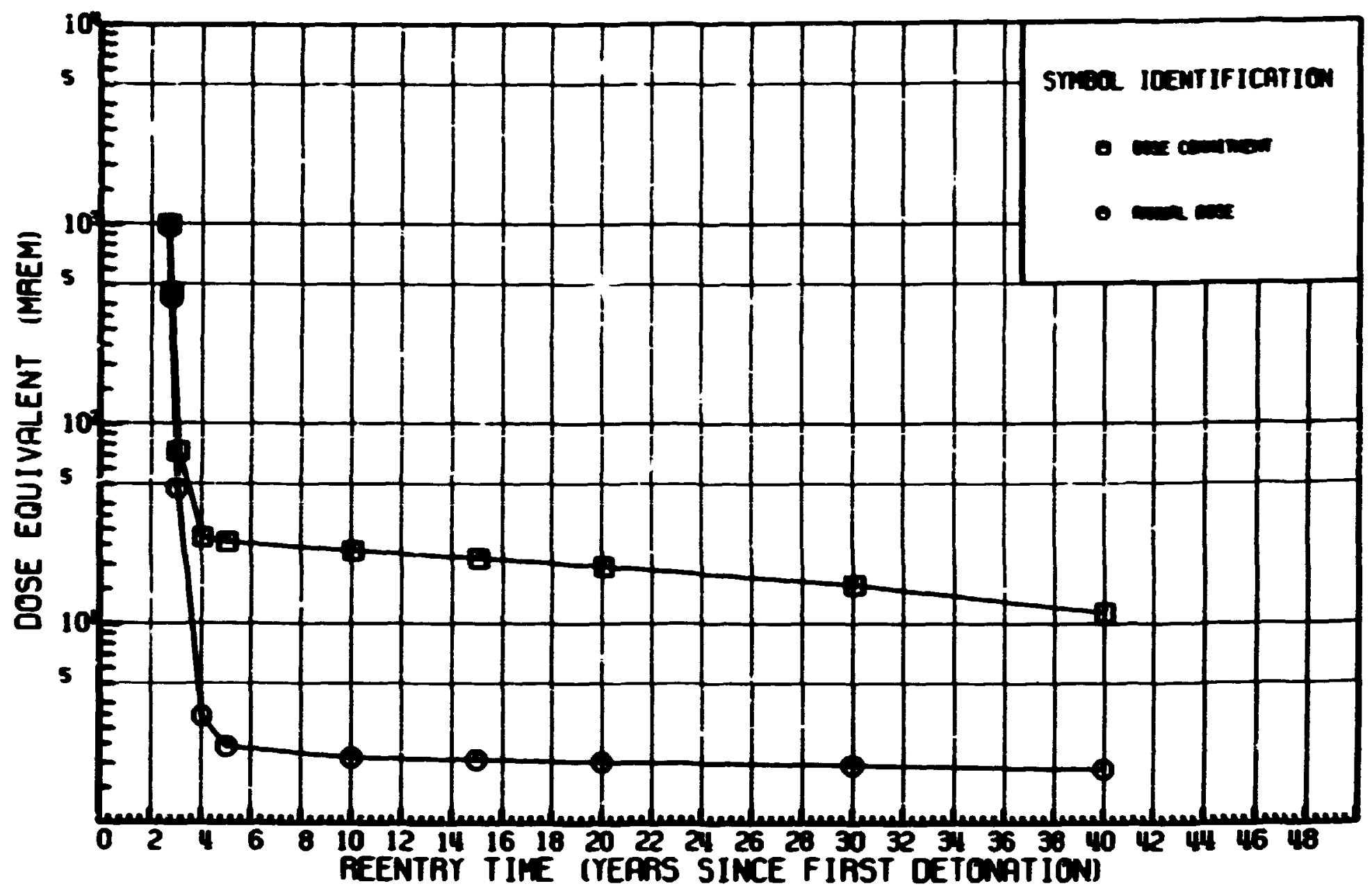

Fig. 7. Maximm Internal Dose Resulting from Radionuclide Ingestion (Ovaries, Watershed 5, Route 17).

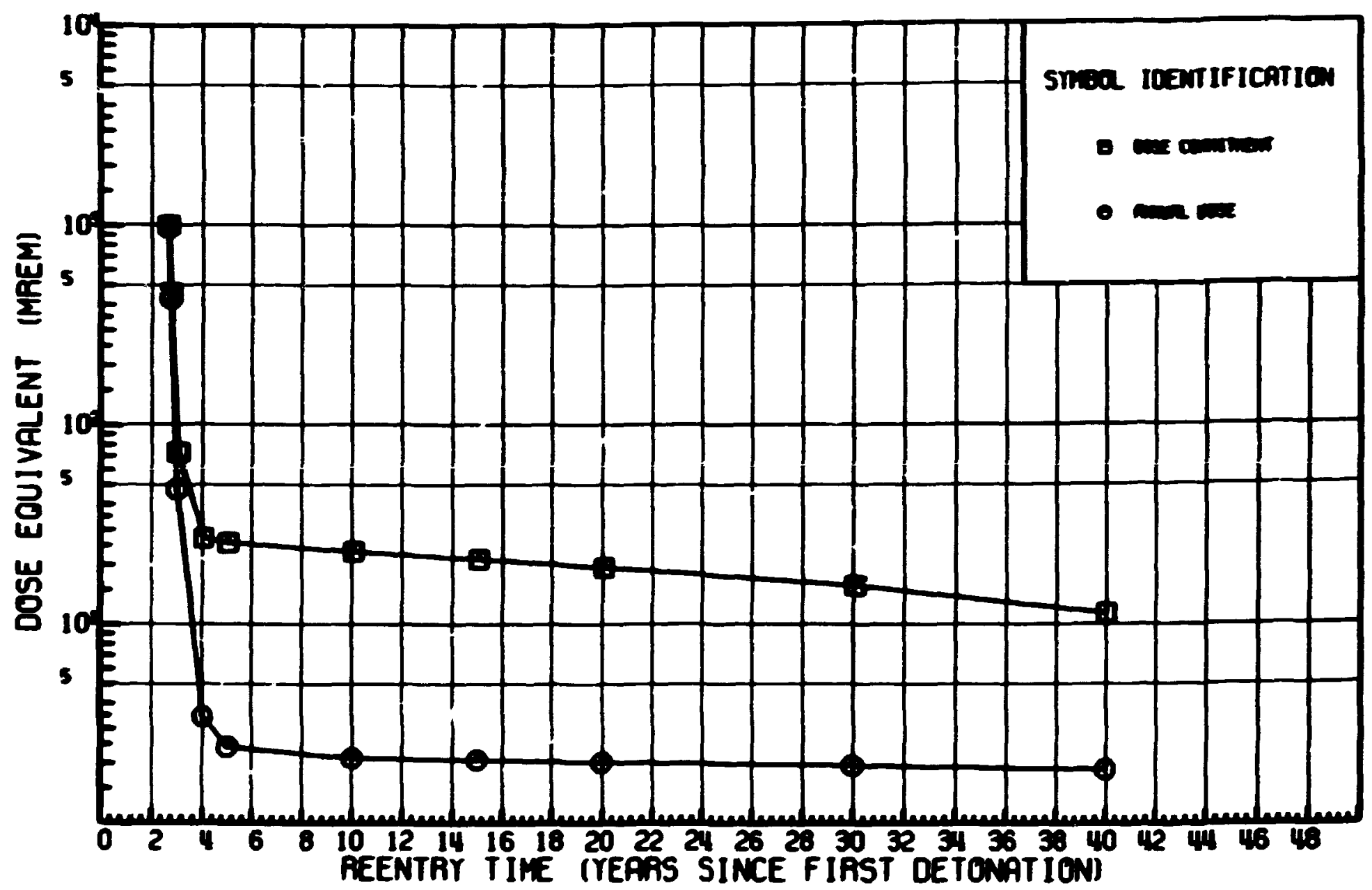

Fie. 8. Maximum Internal Dose Resulting from Radionuclide Ingertion (Lungs, Watershed 5, Route 17). 
APPENDIX IV, Continlied

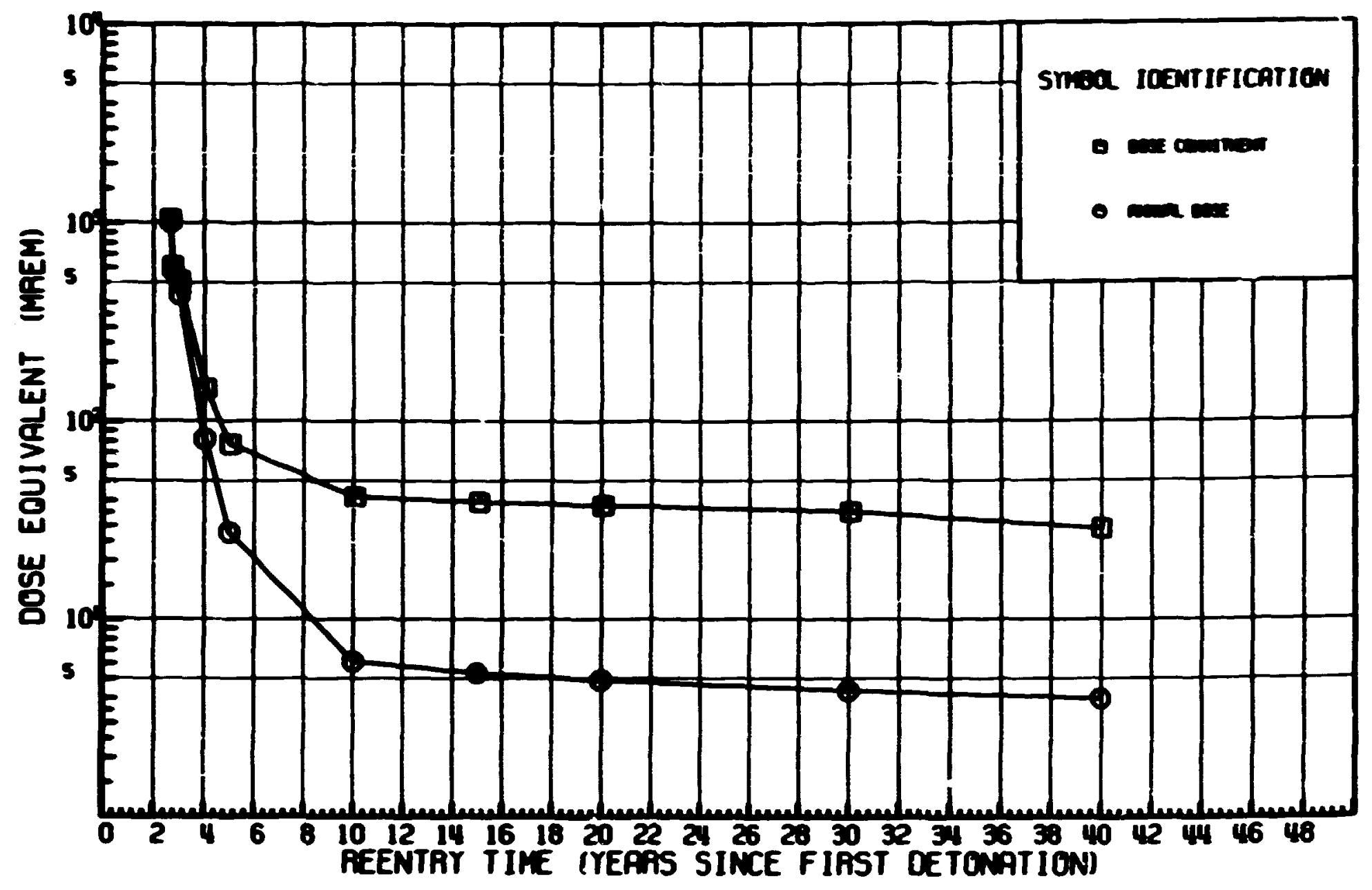

Fig. 9. Maximm Internal Dose Resulting from Radionuclide Ingestion (G.I. Tract, Watershed 5, Route 17). 
APPENDIX V

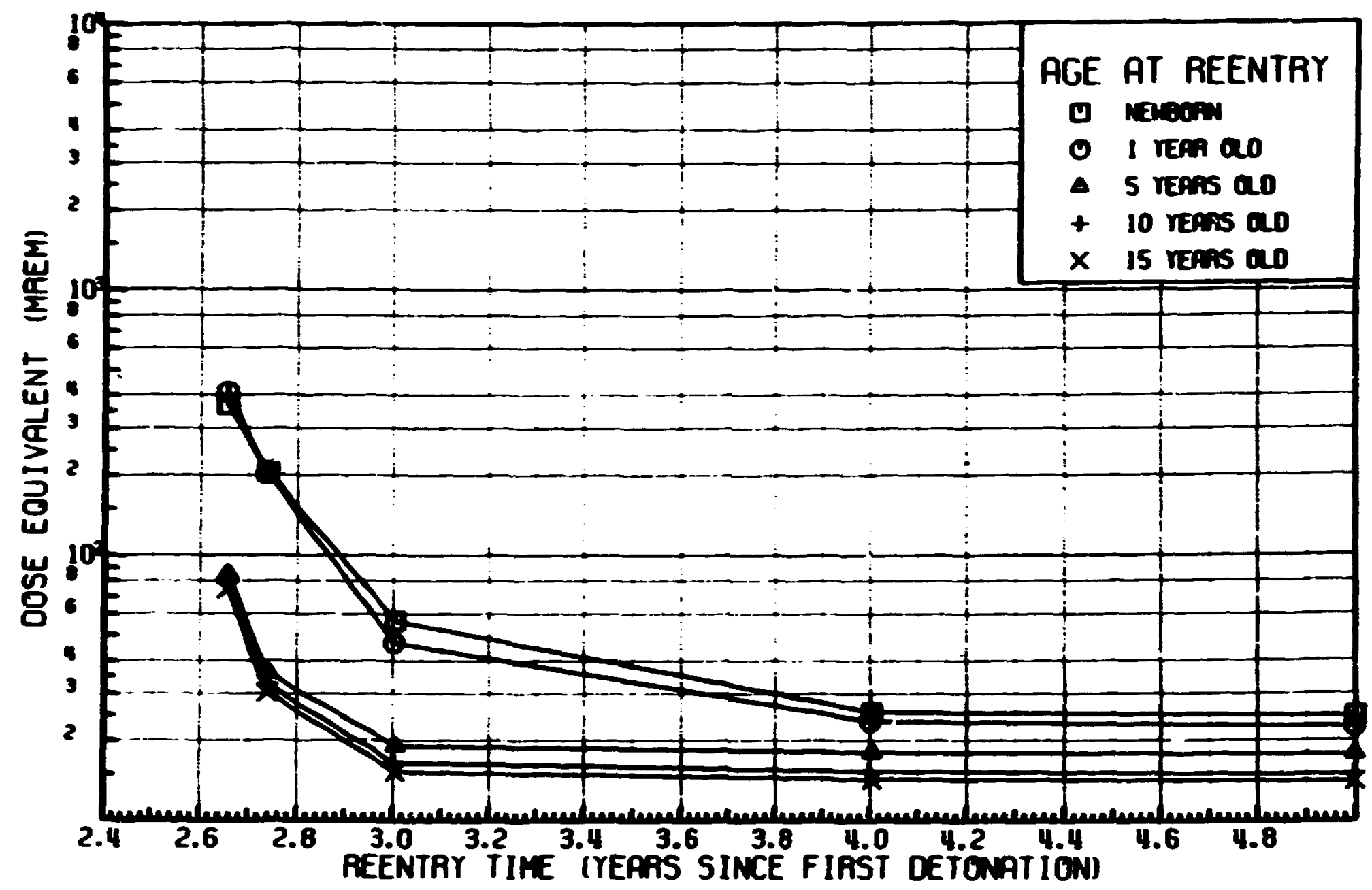

Fig. 1. Dose Commi iment to Total Body as Result of Radionuclide Ingestion (Cuns Indians, Watershed 5, Route 17).

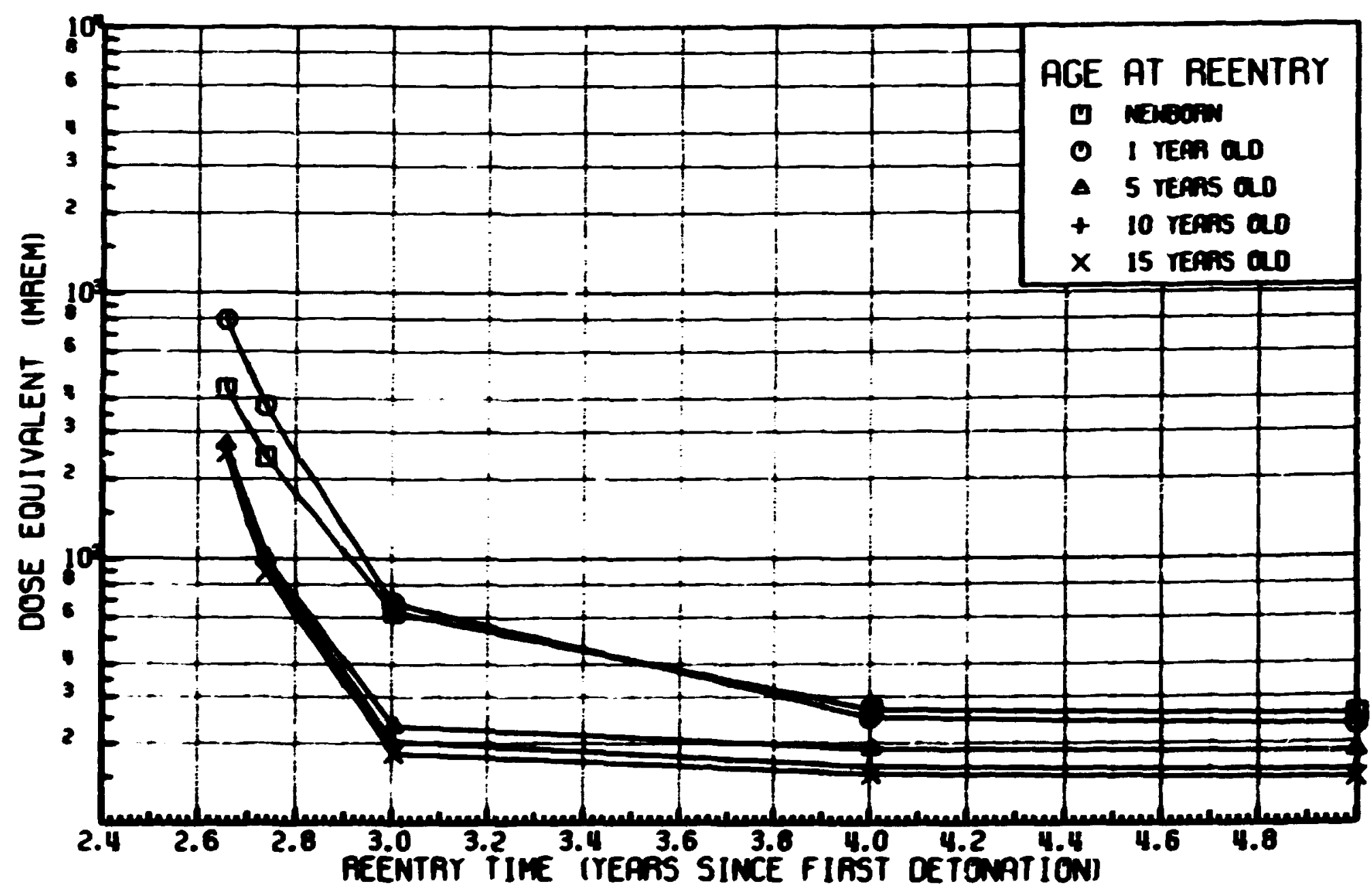

Pig. 2. Dose Comitiment to Totai Sody as Result of Radionuclide Ingestion (Choco Indians, Watershed 5, Route 17). 
APPENDIX V, Continued

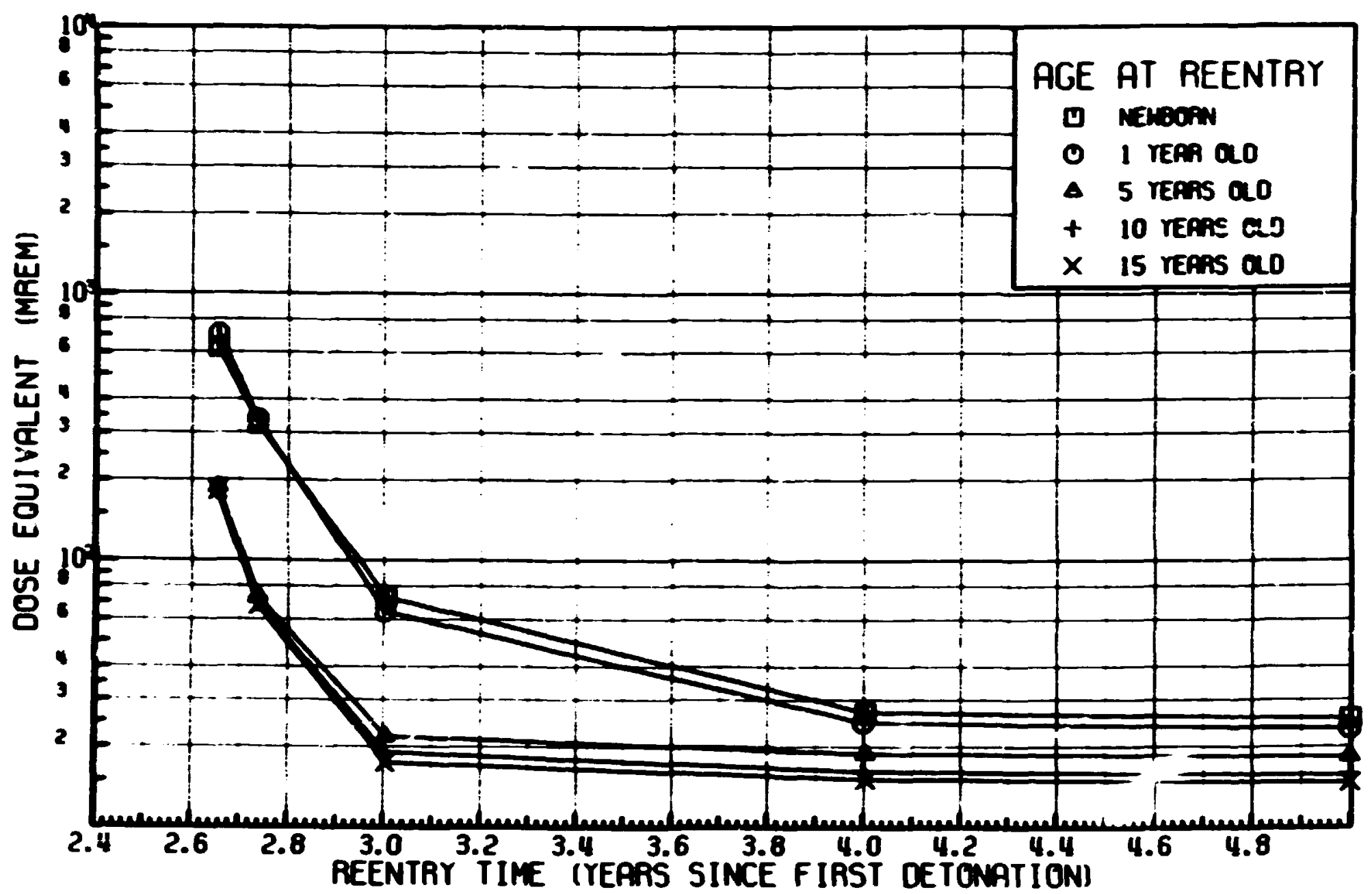

Fig. 3. Dose Commitment to Total Body as Result of Radionuclide Ingestion (Negrces, Watershed 5, Route 17).

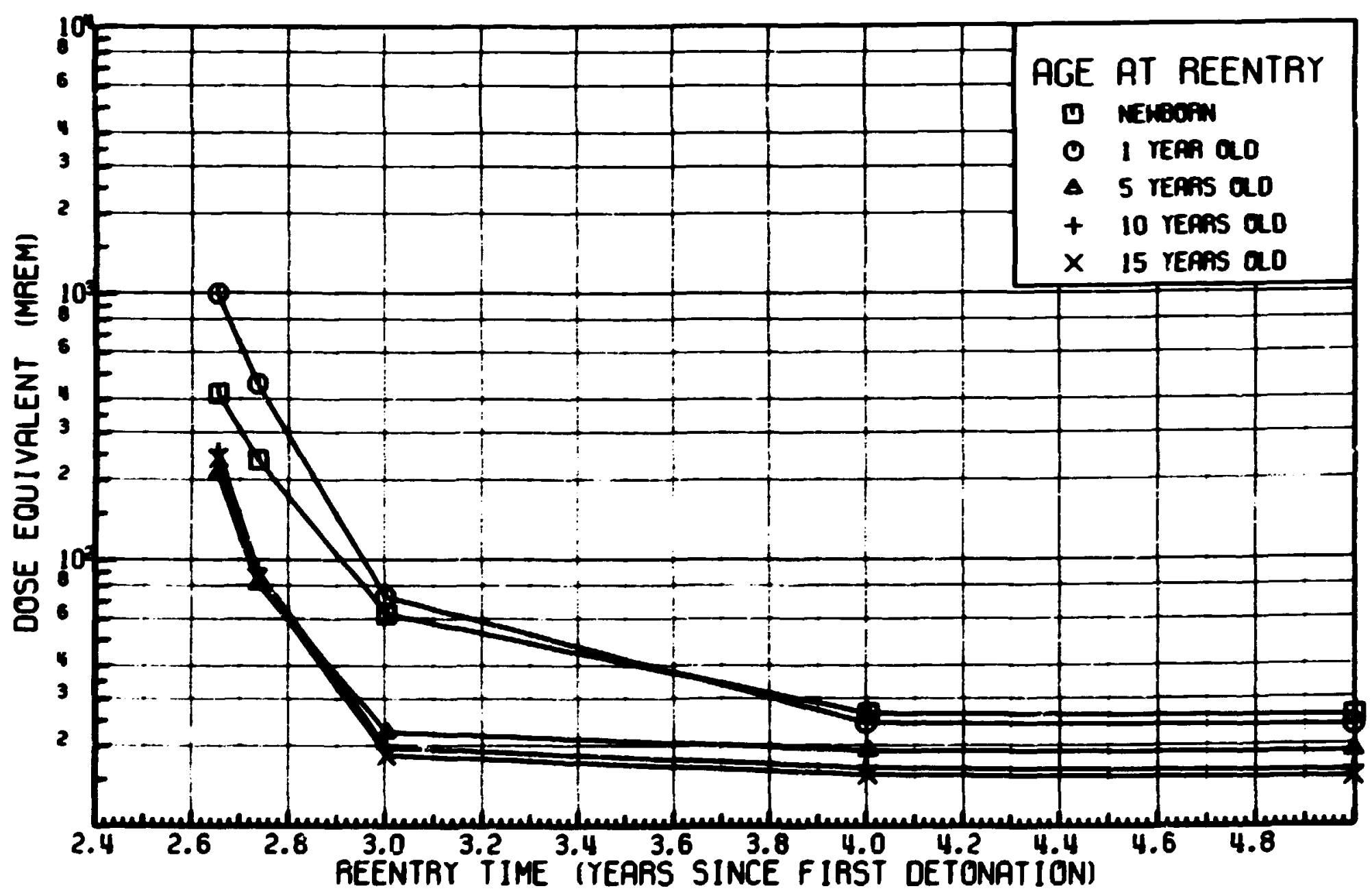

Fig. 4 Dose Commitment to Total Body as Result of Radionuclide Ingestion (Colonists, Watershed 5, Route 17). 
APPENDIX V, Continued

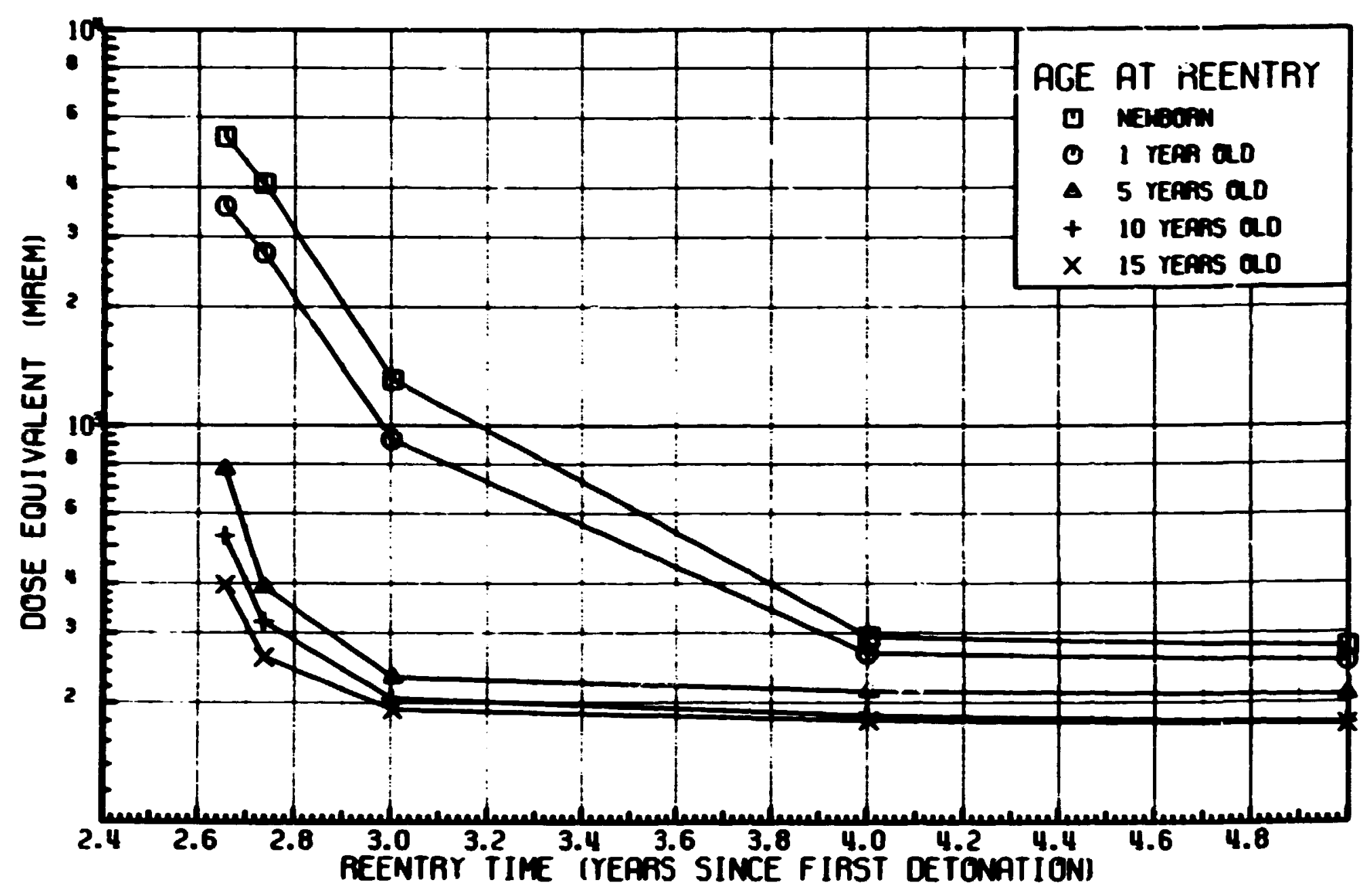

Fig. 5. Dose Commitment to Bone as Result of Radionuclide Ingestion (Cuna Indians, Watershed 5, Route 17).

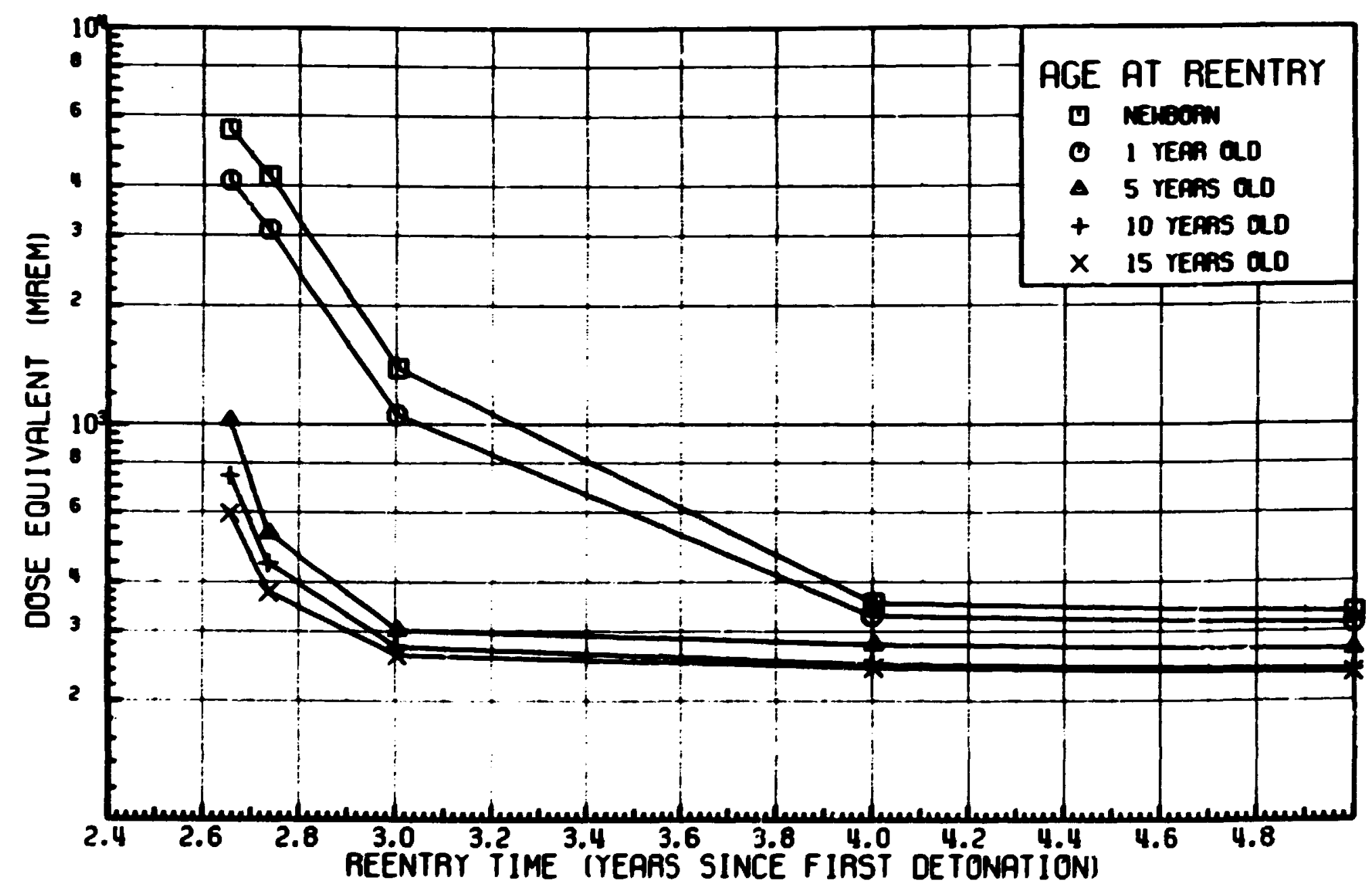

Fig. 6. Dose Commitment to Bone as Result of Radionuclide Ingestion (Choco Indians, Watershed 5, Route 17). 
APPENDIX V, Continued

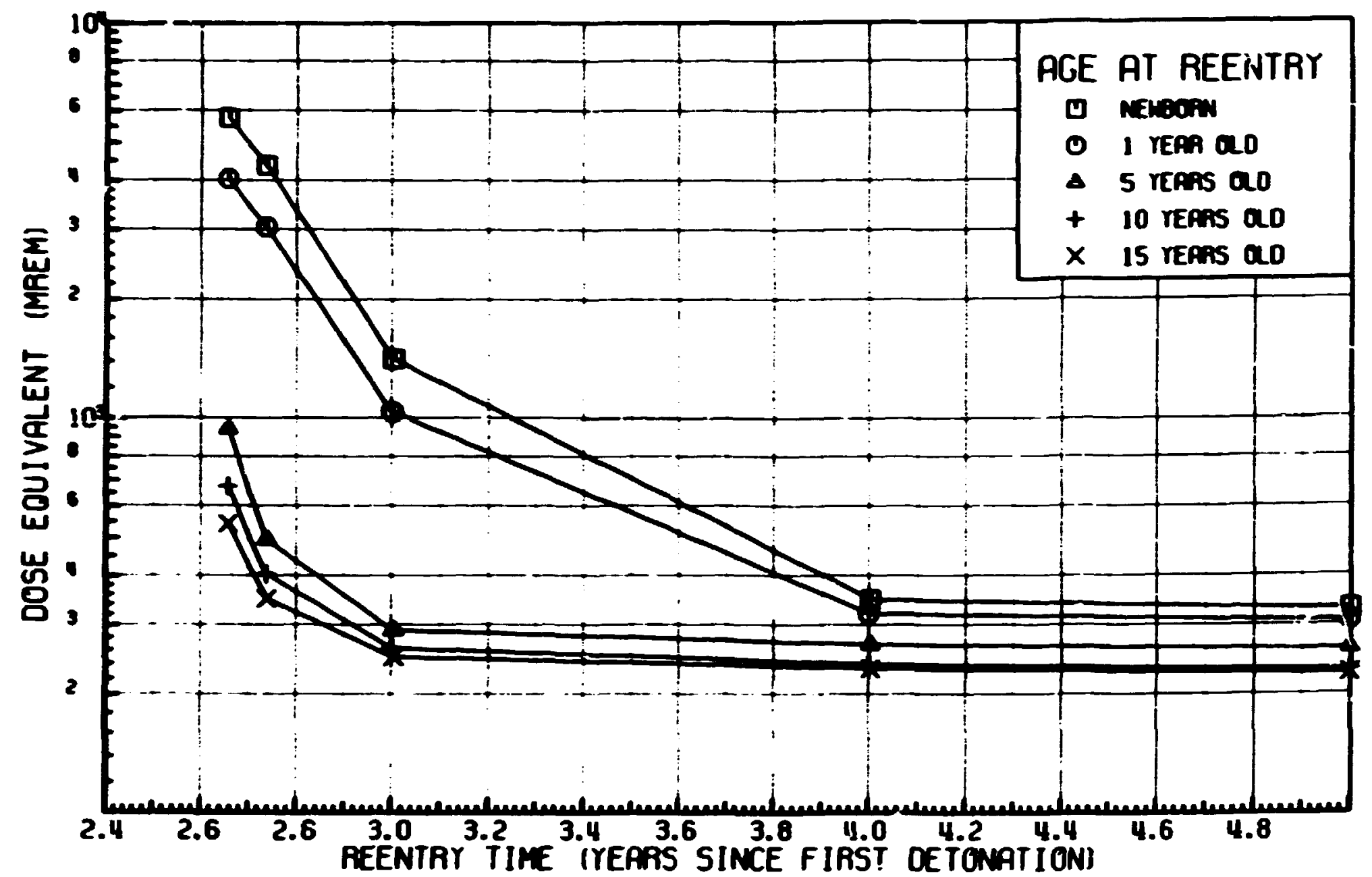

Fig. 7. Dose Commitment to Bone as Result of Radicnuclide Ingestion (Negroes, Watershed 5, Route .77).

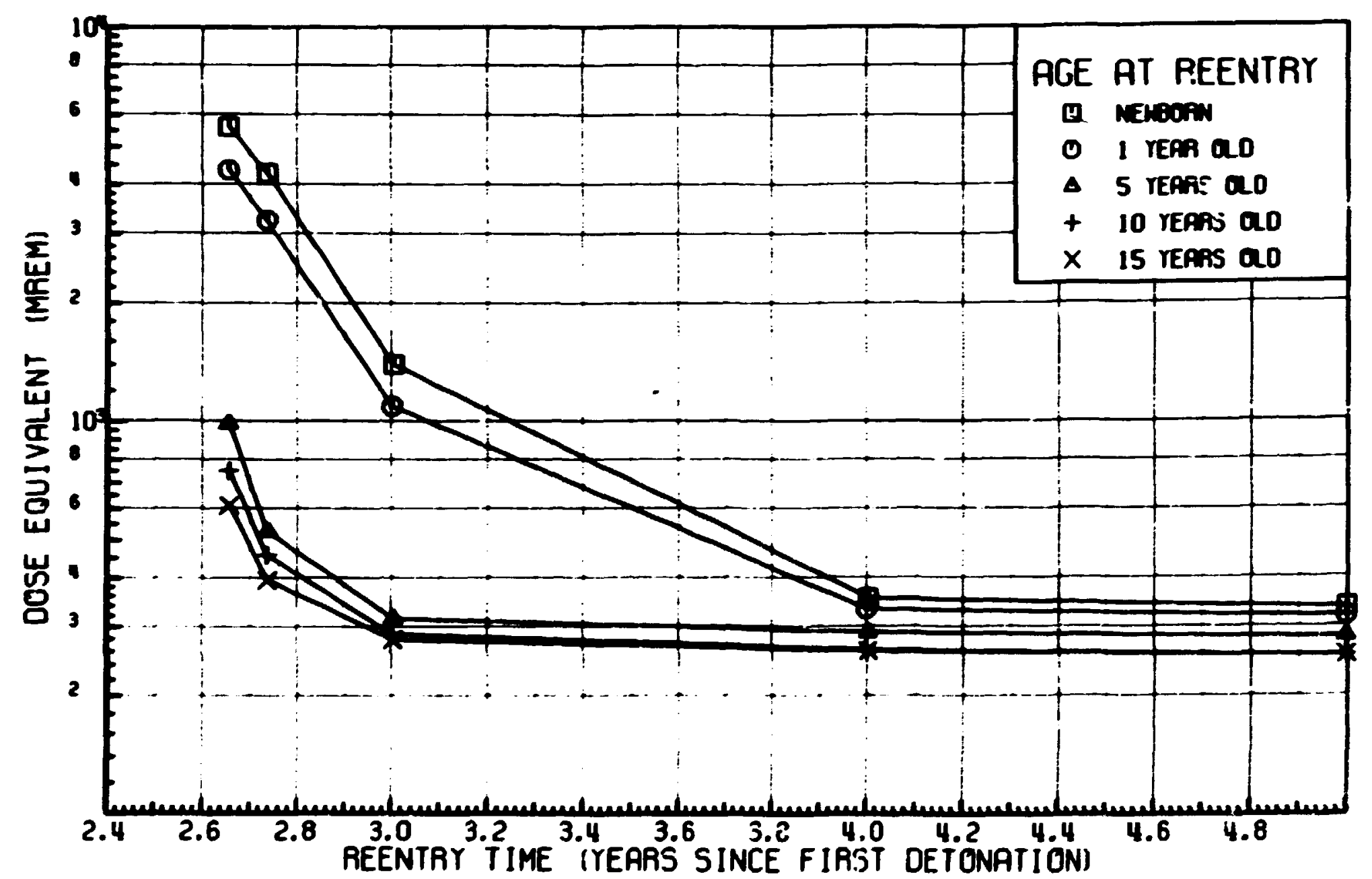

Fig. 8. Dose Cormitment to Bone as Result of Radionuclide Ingestion (Coloinists, Watershed 5, Route 17). 
APPER.DIX VI

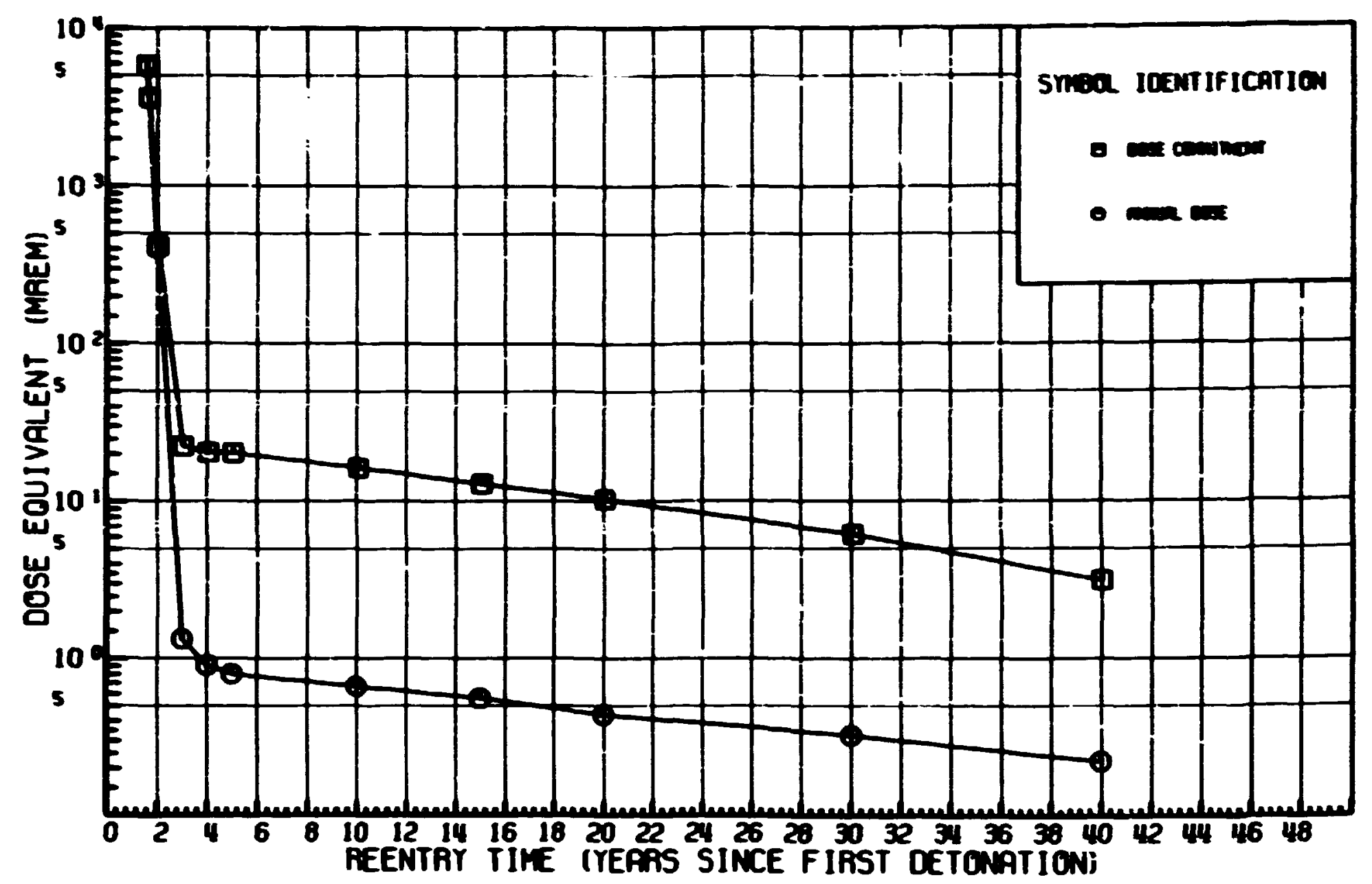

Fig. 1. Maximum Internal Dose Resulting from Radionuclide Ingestion (Kidneys, Watershed 2, Route 25).

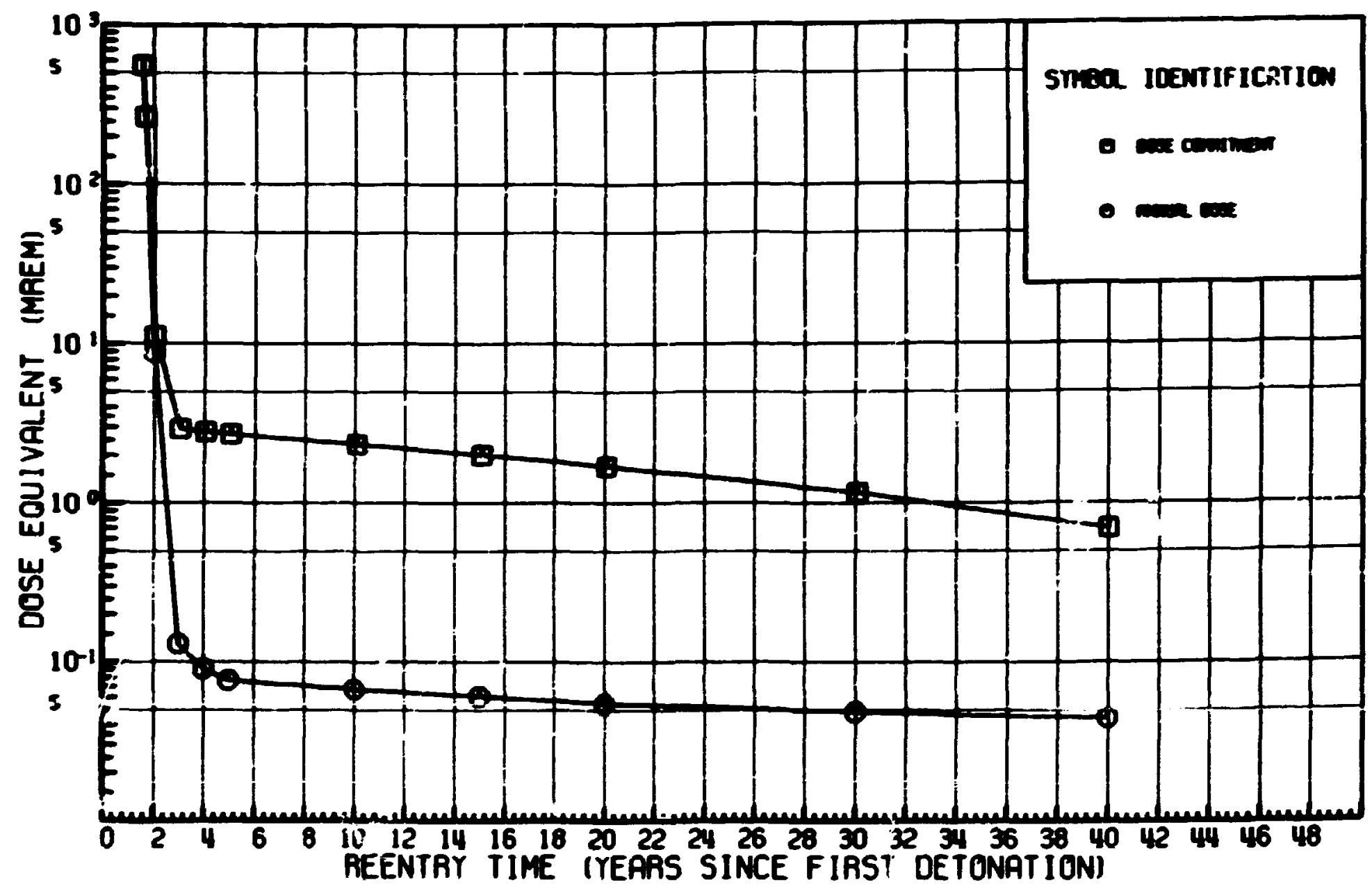

Fig. 2. Maximum Internal Dose Resulting from Radionuclide Ingestion (Total Body, We.tershed 2, Route 25). 
APPERIDIX VI, Continued

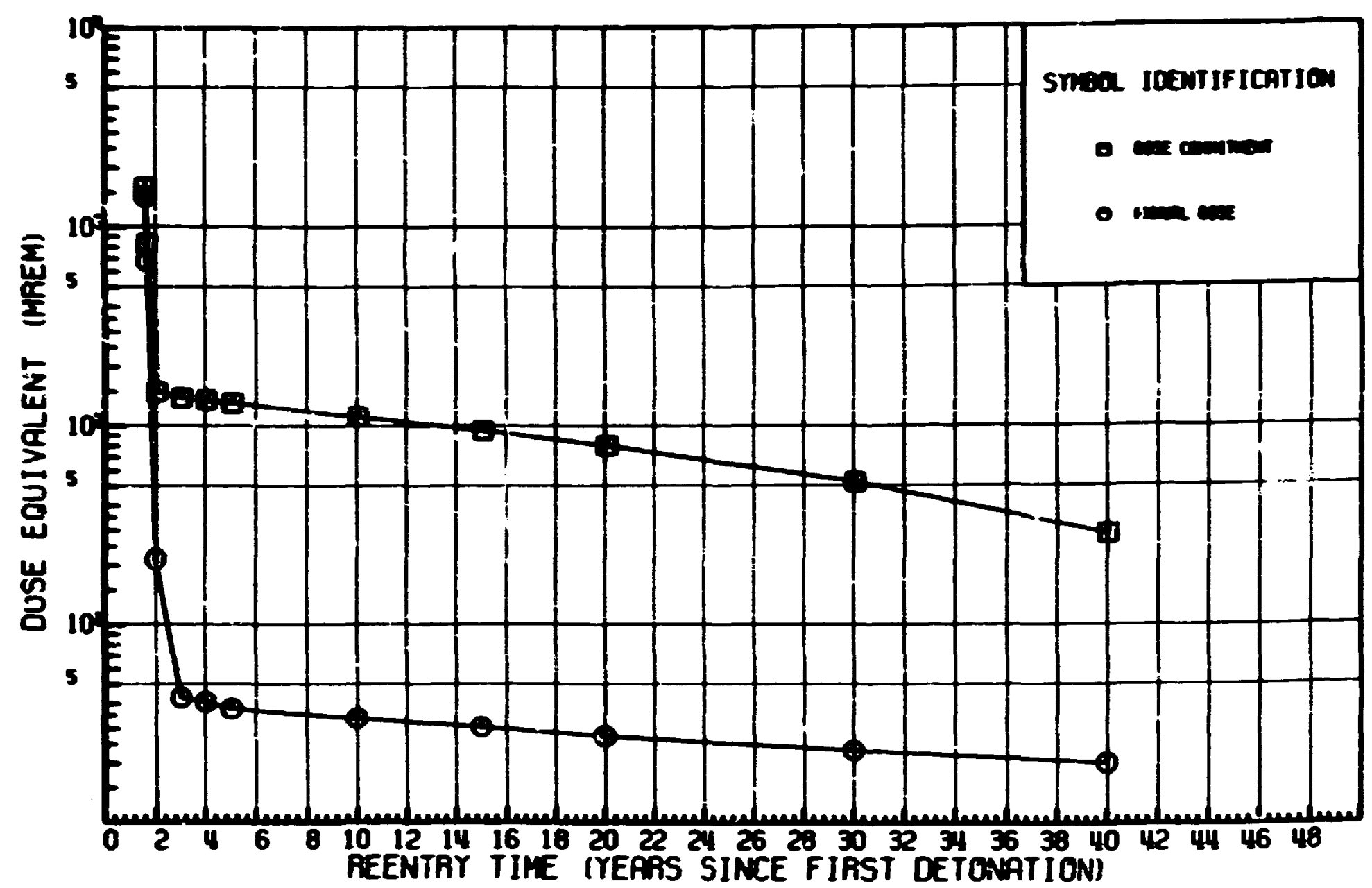

Fig. 3. Maximm Internal Dose Resulting irom Radionuclide Ingestion (Bone, Watershed 2, Route 25).

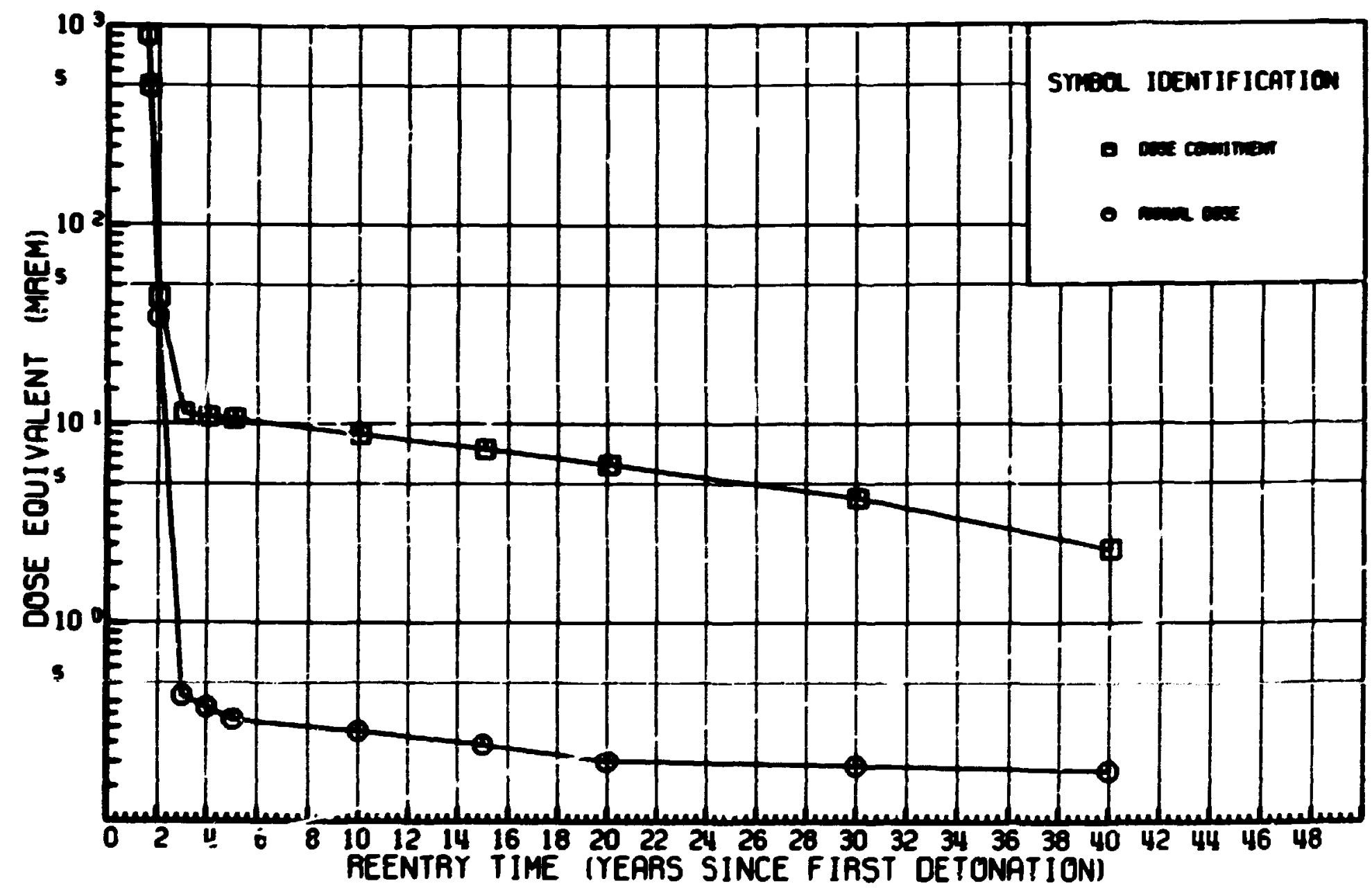

Fig. 4. Maximum Internal Dose Resulting from Radionuclide Ingestion (Liver, Watershed 2, Route 25). 


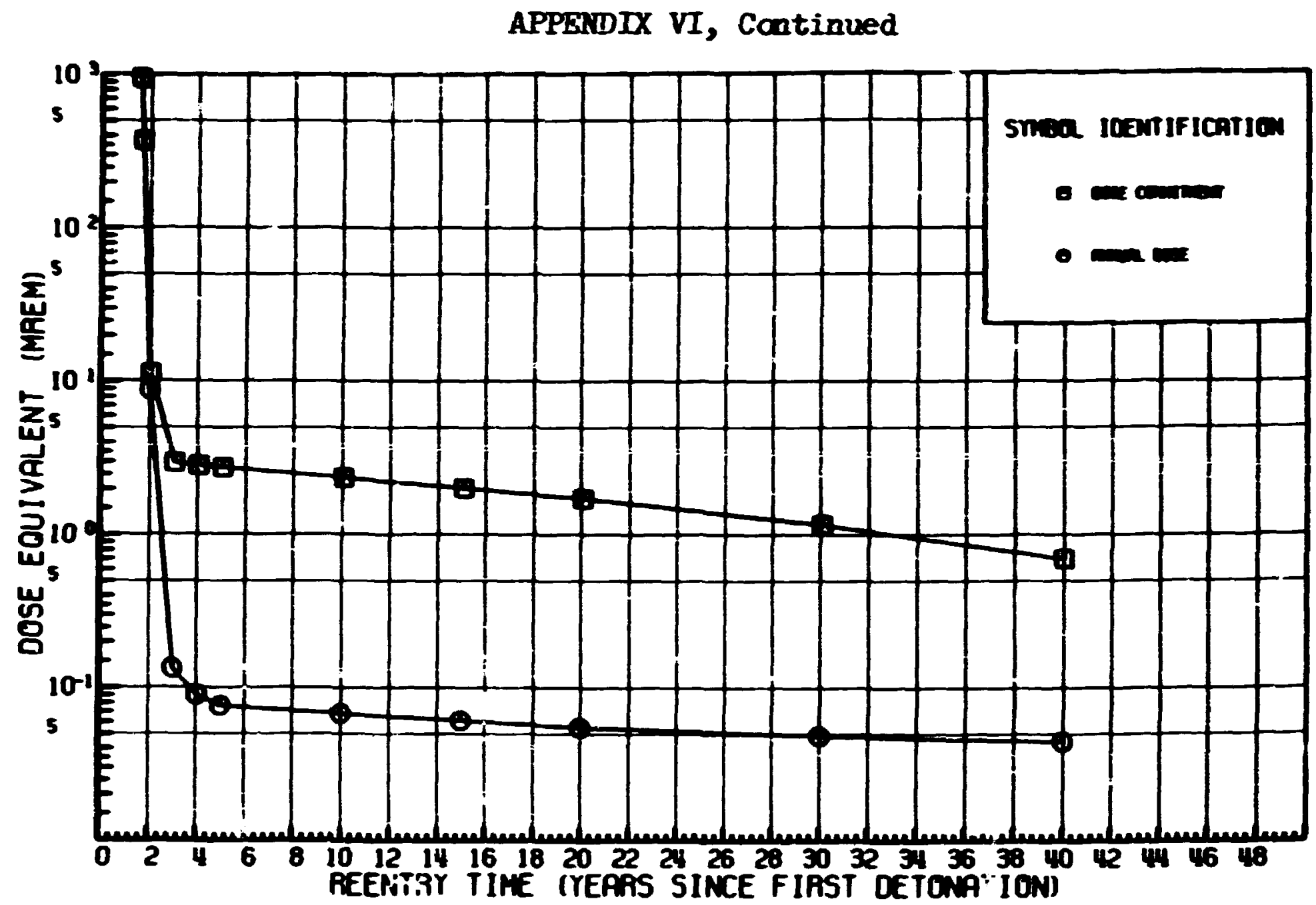

Fig. 5. Maximum Internal Dose Resulting irom Radionuclide Ingestion (Thyroid, Natershed 2, Route 25).

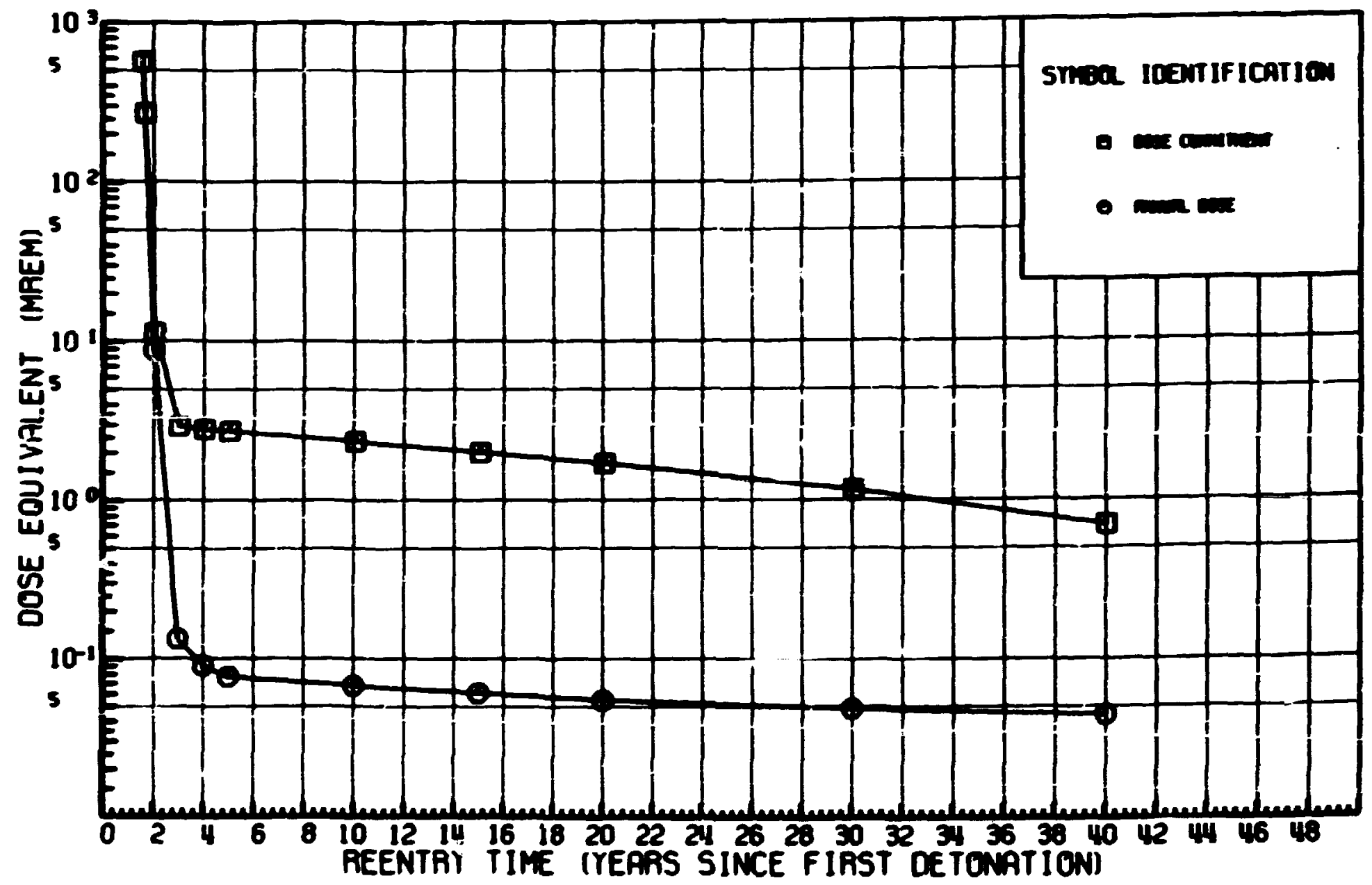

Fig. 6. Maximm Internal Dose Resulting from Radionuclide Ingestion (Testes, Watershed 2, Route 25). 
APPBIDIX VI, Contimed

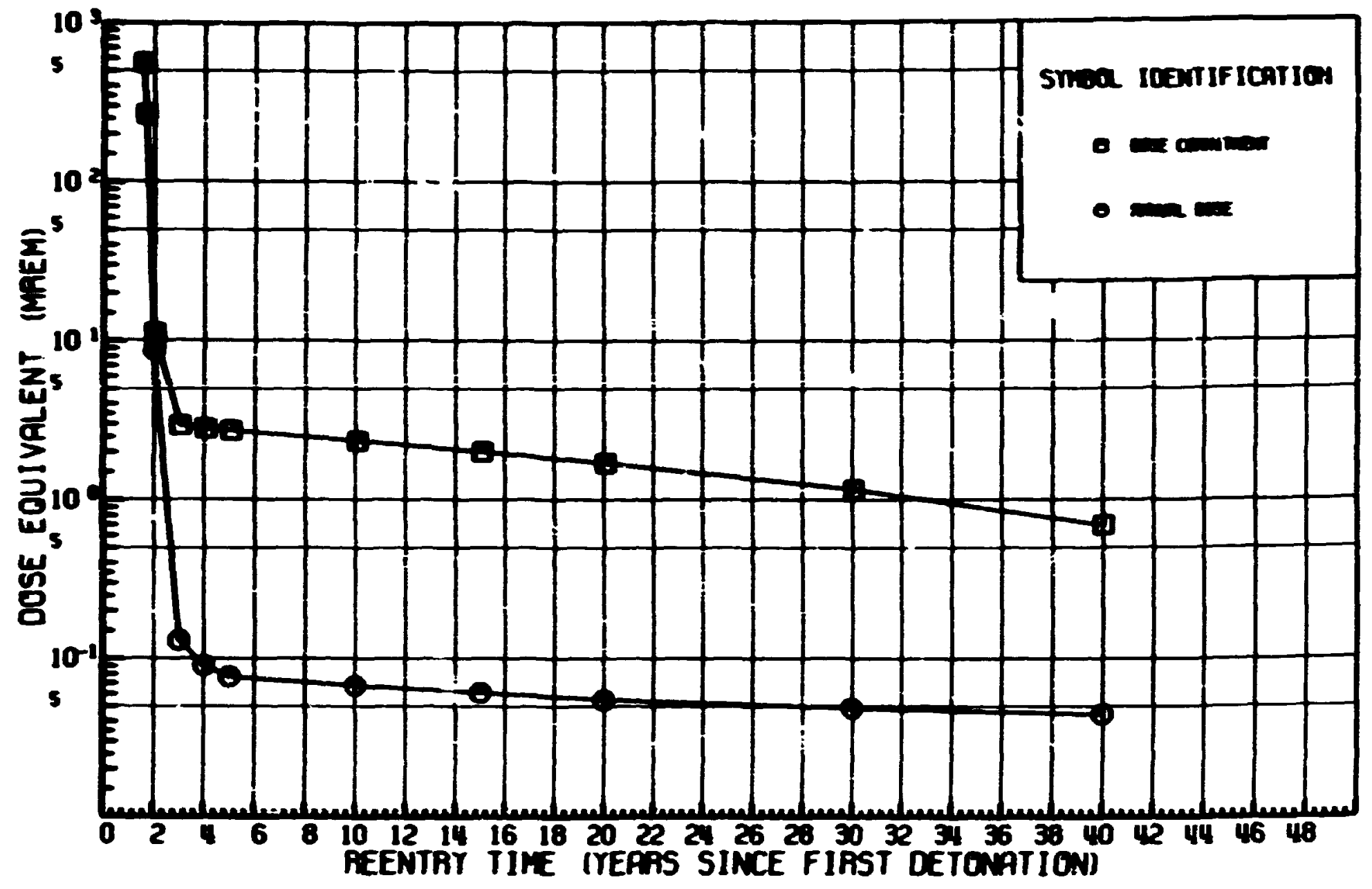

Fig. 7. Maximm Internal Dose Resulting from Radionuclide Ingestion (Ovaries, Hatershed 2, Route 25).

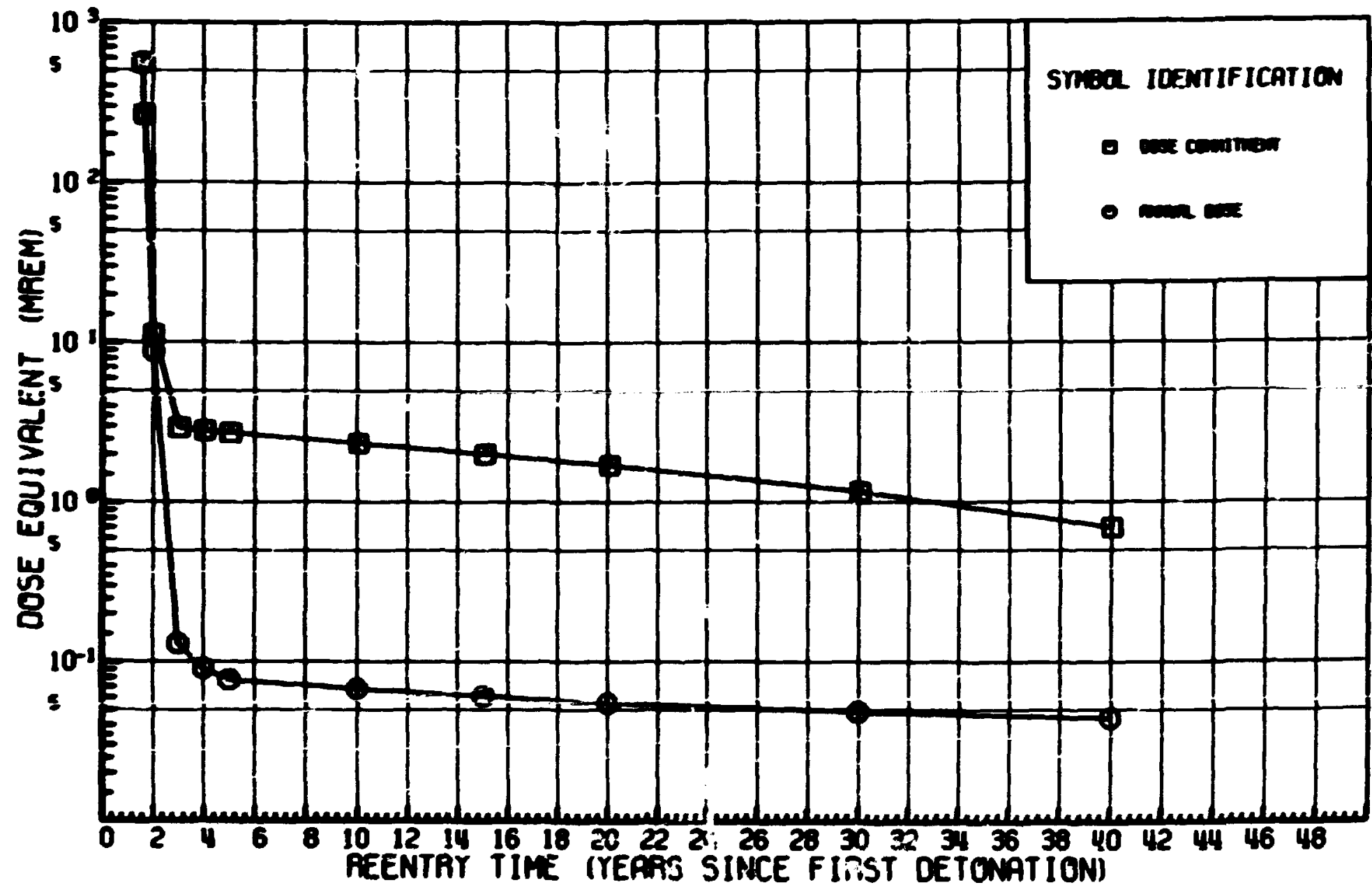

F18. 8. Maximm Internal Dose Resulting from Radionuclide Ingestion (Lungs, Watershed 2, Route 25). 


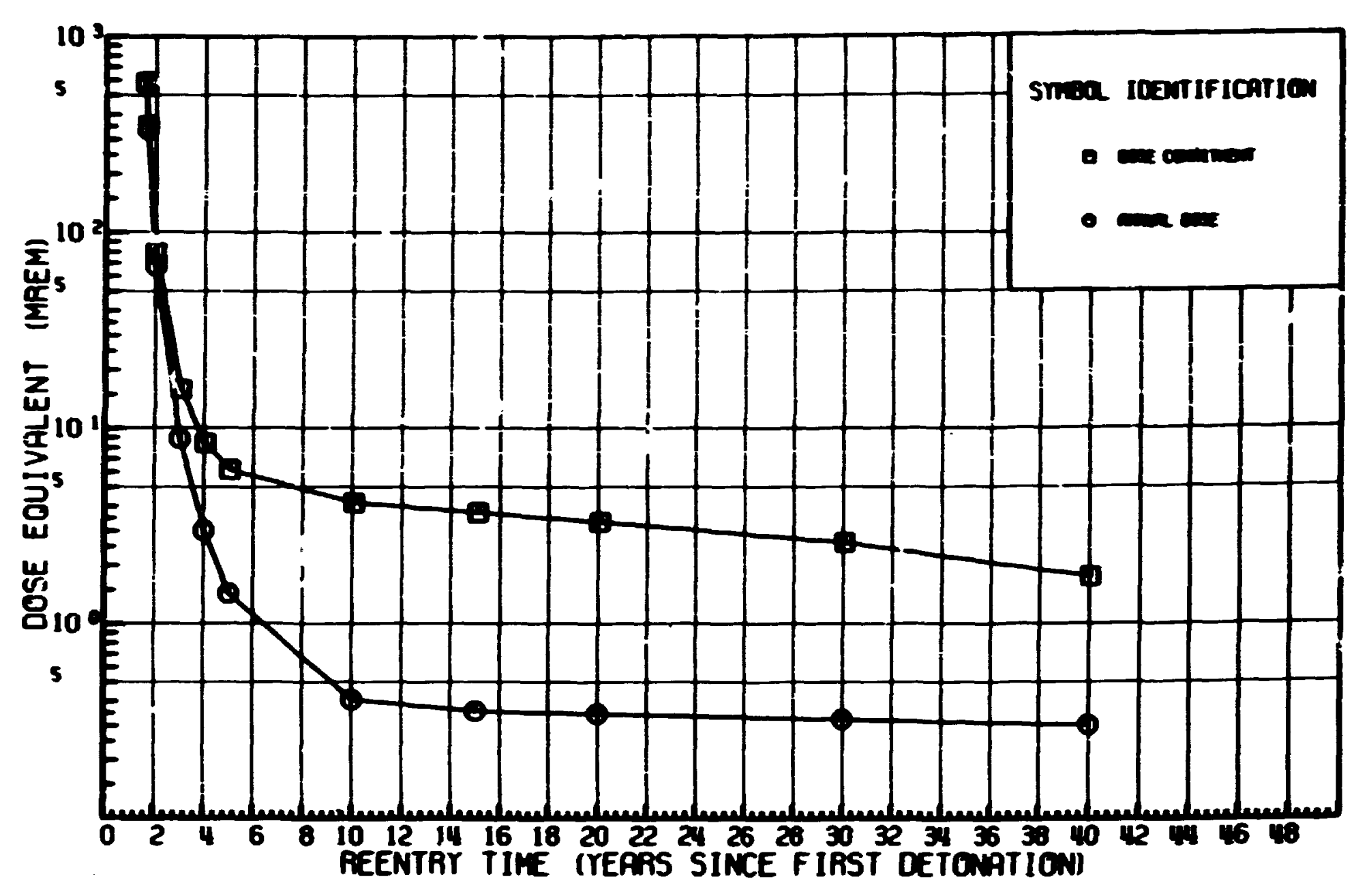

Fig. 9. Maximm Internal Dose Resulting from Radionuclide Ingestion (G.I. Tract, Watershed 2, Route 25). 


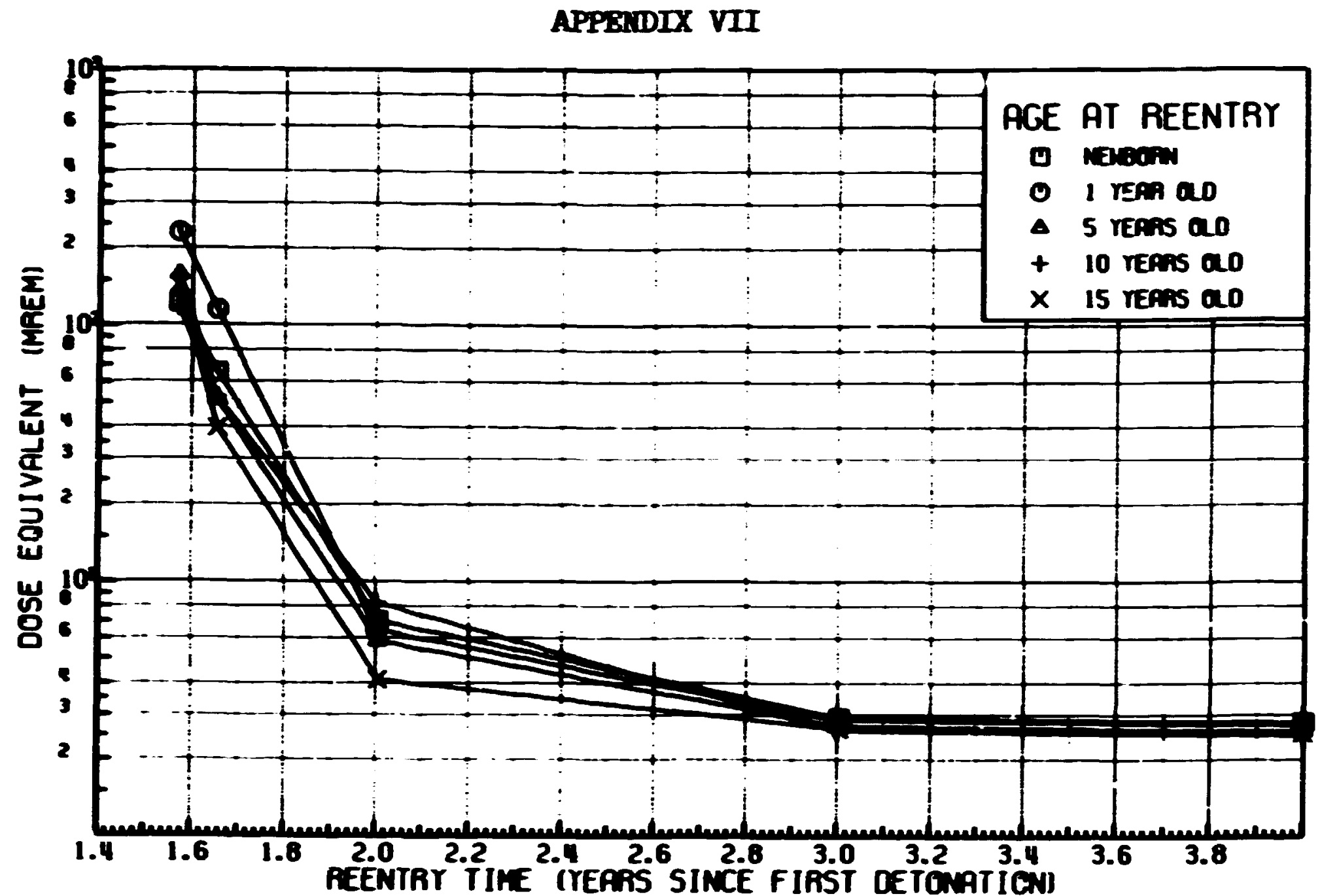

Fig. 1. Dose Comitment to Total Body as Result of Radionuclide Ingestion (Cursa Indians, Hatershed 2, Route 25).

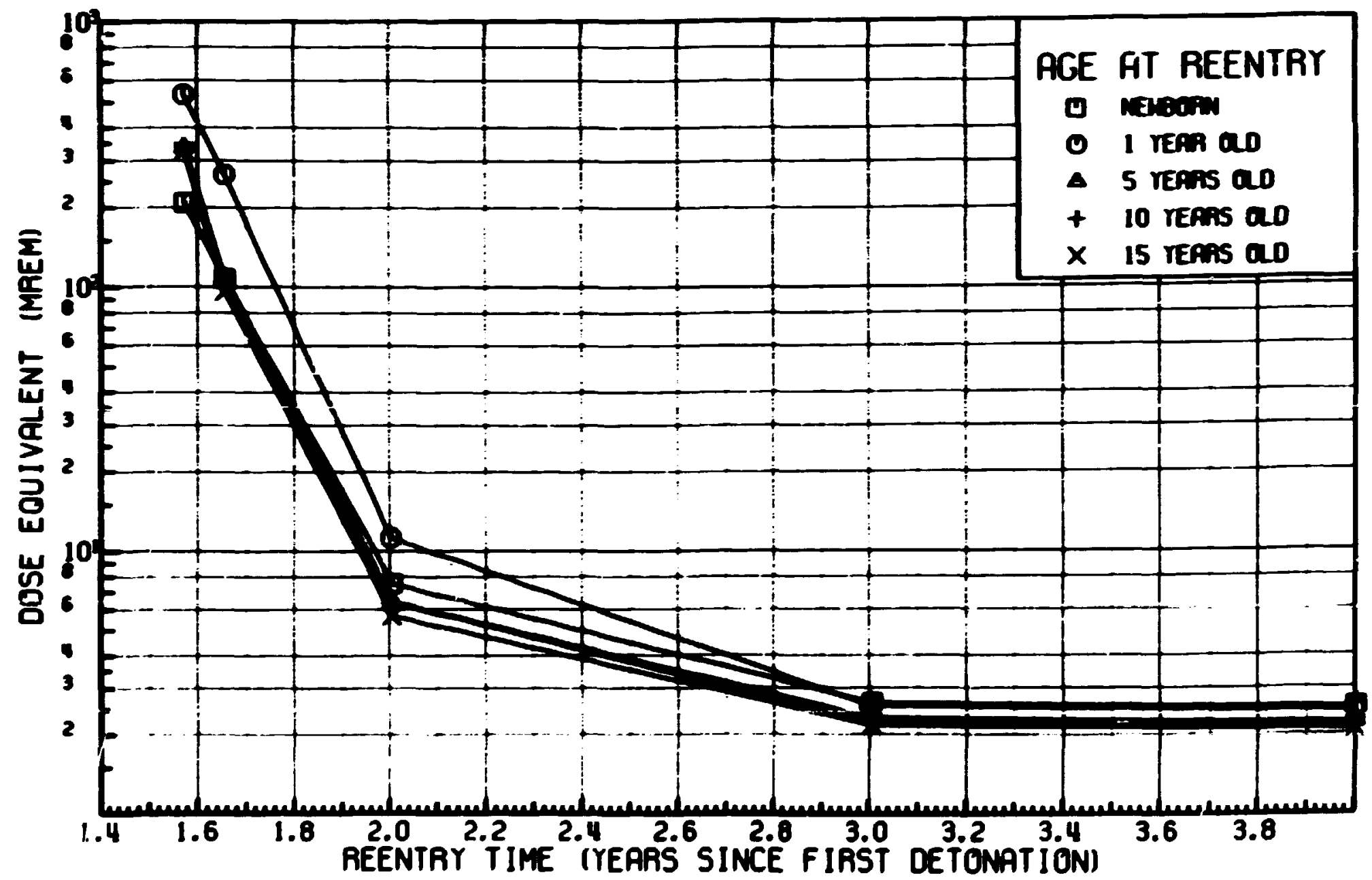

Hig. 2. Dose Cormitment to Total Body as Result of Radionuclide Ingestion (Choco Indians, Watershed 2, Route 25). 
APPEDIX VII, Continued

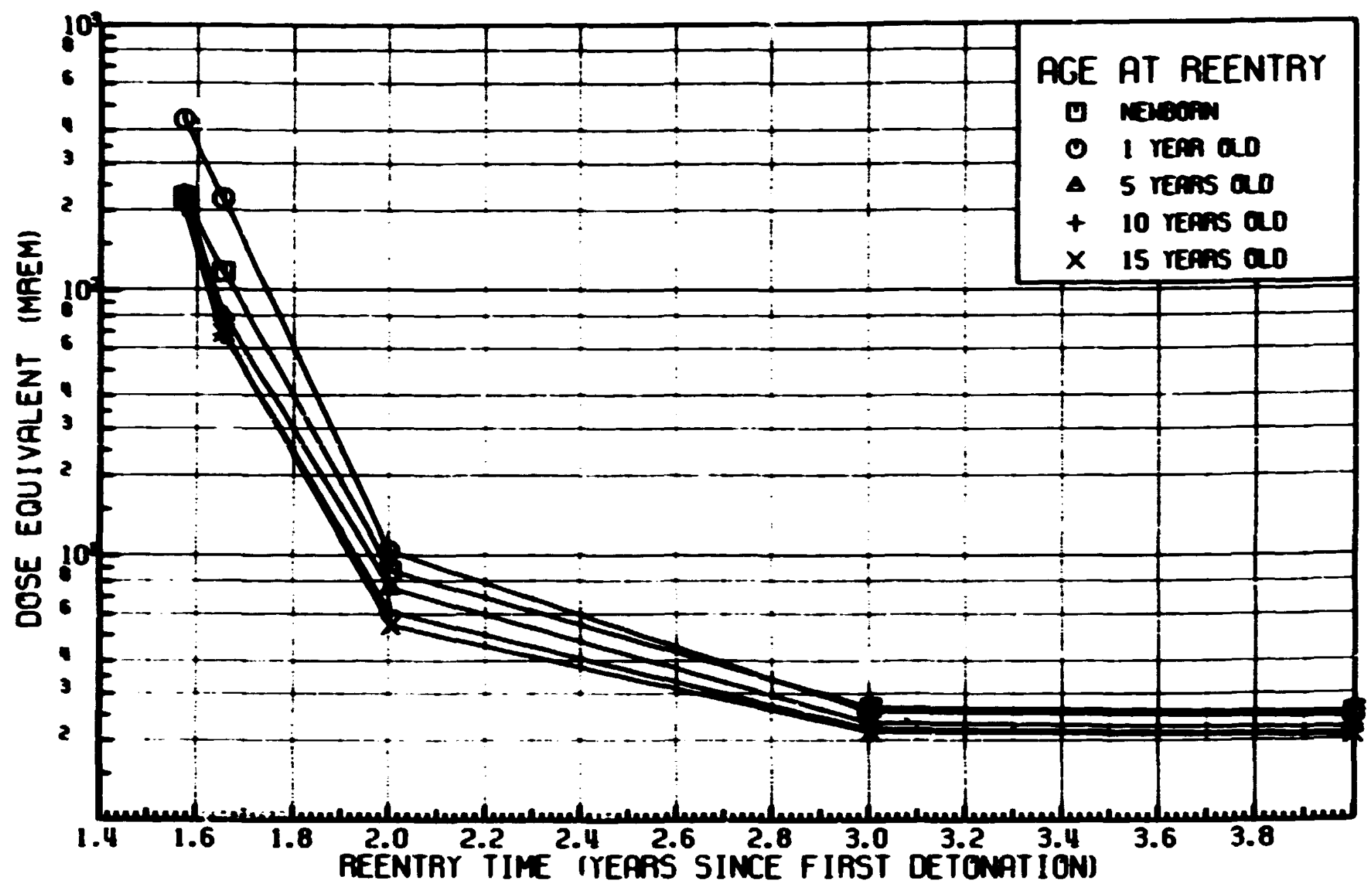

Fi.j. 3. Dose Commitment to Total Body as Result of Radionuclide Ingestion (Negrces, Hatershed 2, Route 25).

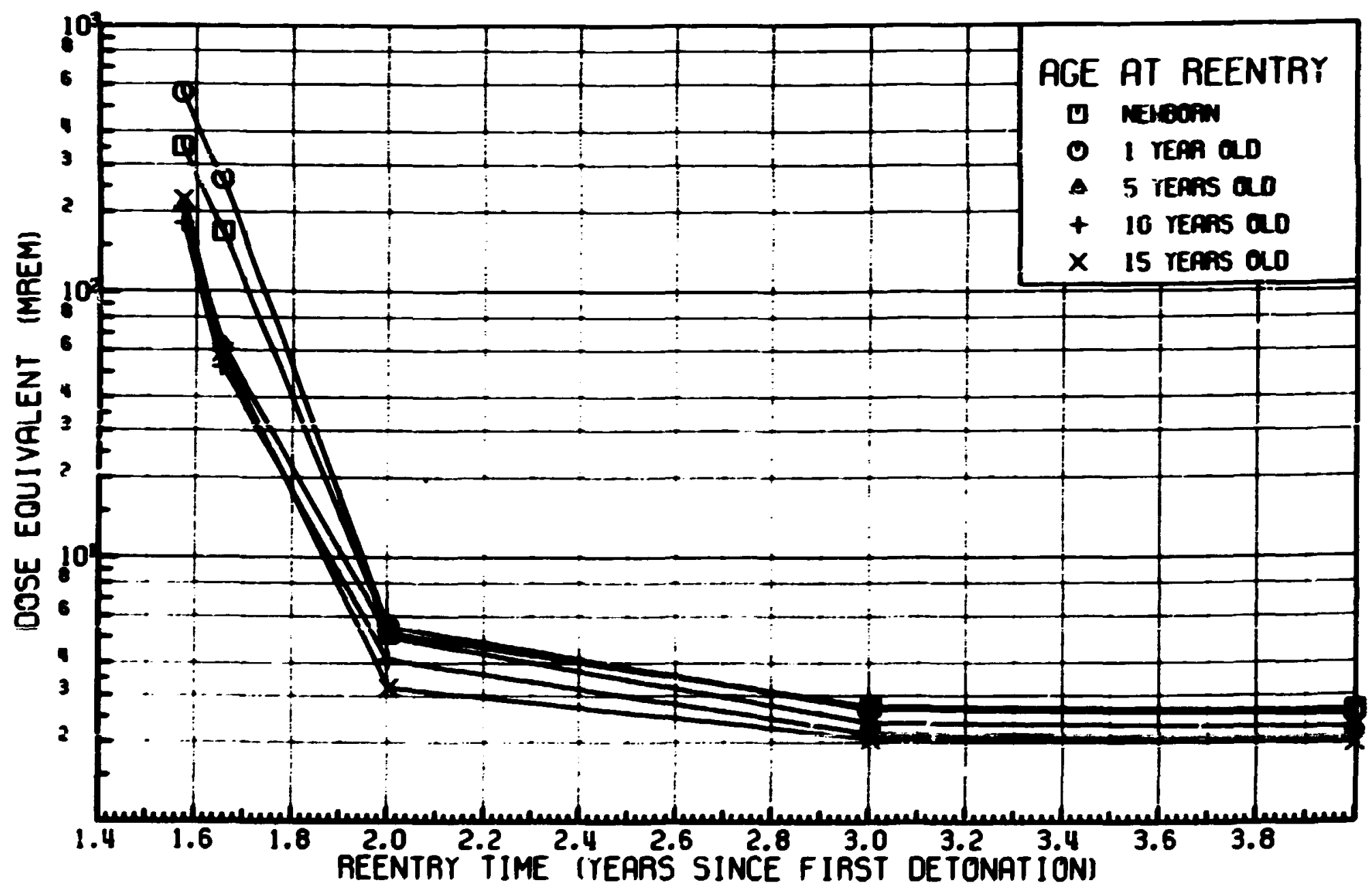

Fig. 4. Dose Commitment to Total Body as Result of Radionuclide Ingestion (Colonists, Watershed 2, Route 25). 
APPERIX VII, Continued

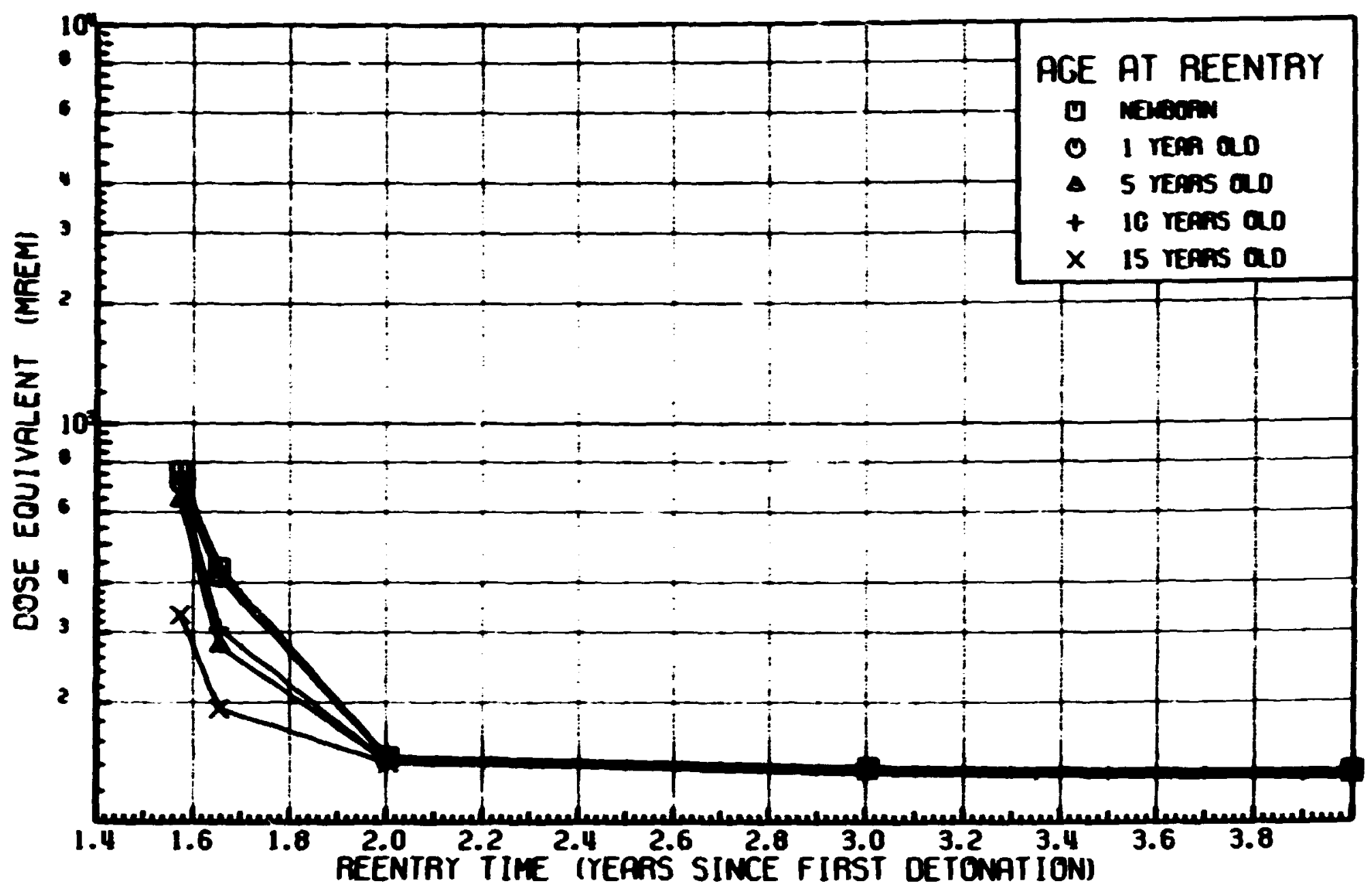

Fig. 5. Dose Commitment to Bone as Result of Radionuclide Ingestion (Cuna Indians, Watershed 2, Route 25).

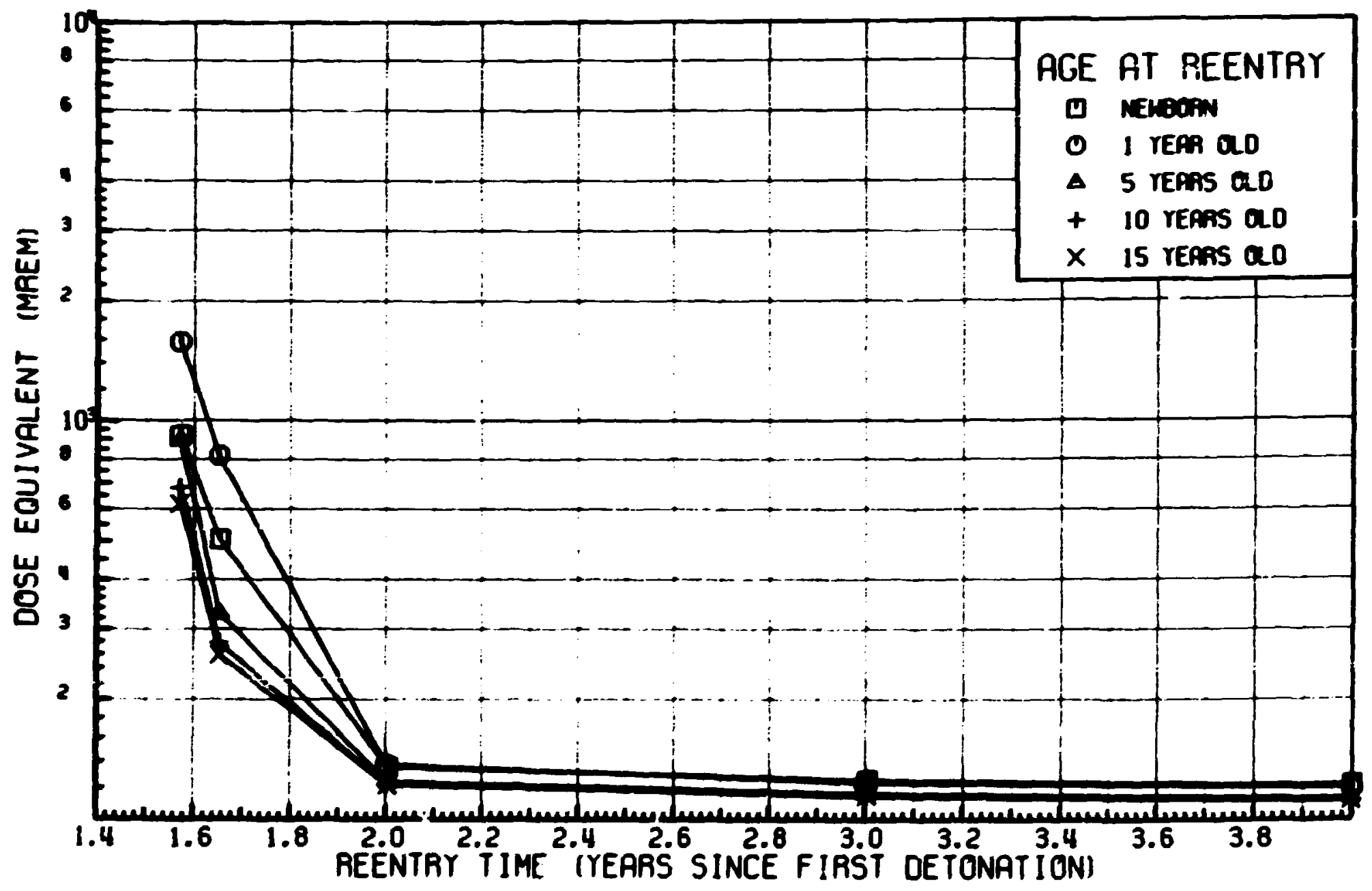

Fig. 6. Dose Comnitment to Bone as Result of Radionuclide Ingestion (Choco Indians, Watershed 2, Route 25). 
APPE.DIX VII, Contimed

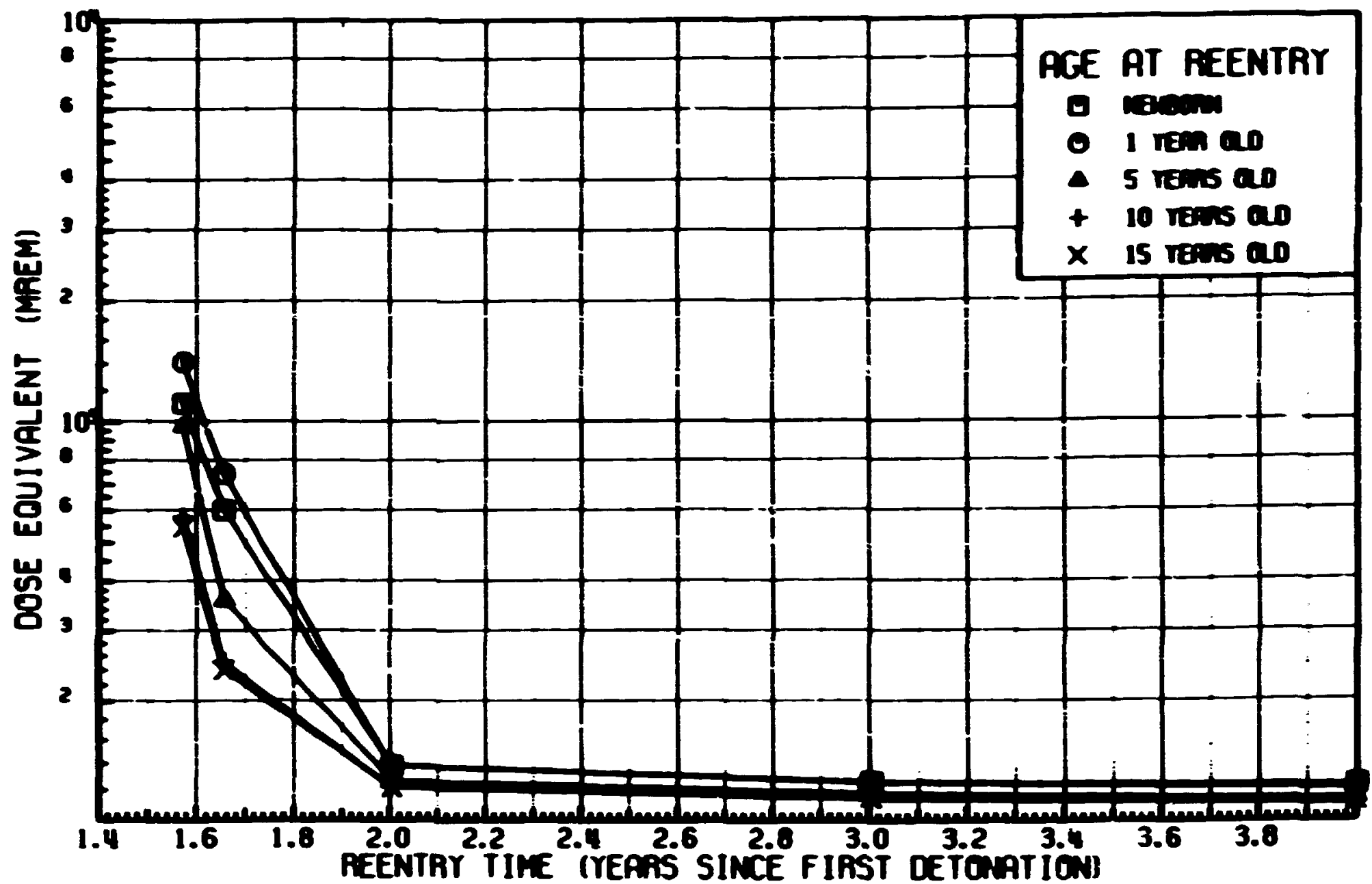

Fig. 7. Nose Comitment to Bone as Result of Radiomalide Ingestion (Negroes, Watershed 2, Route 25).

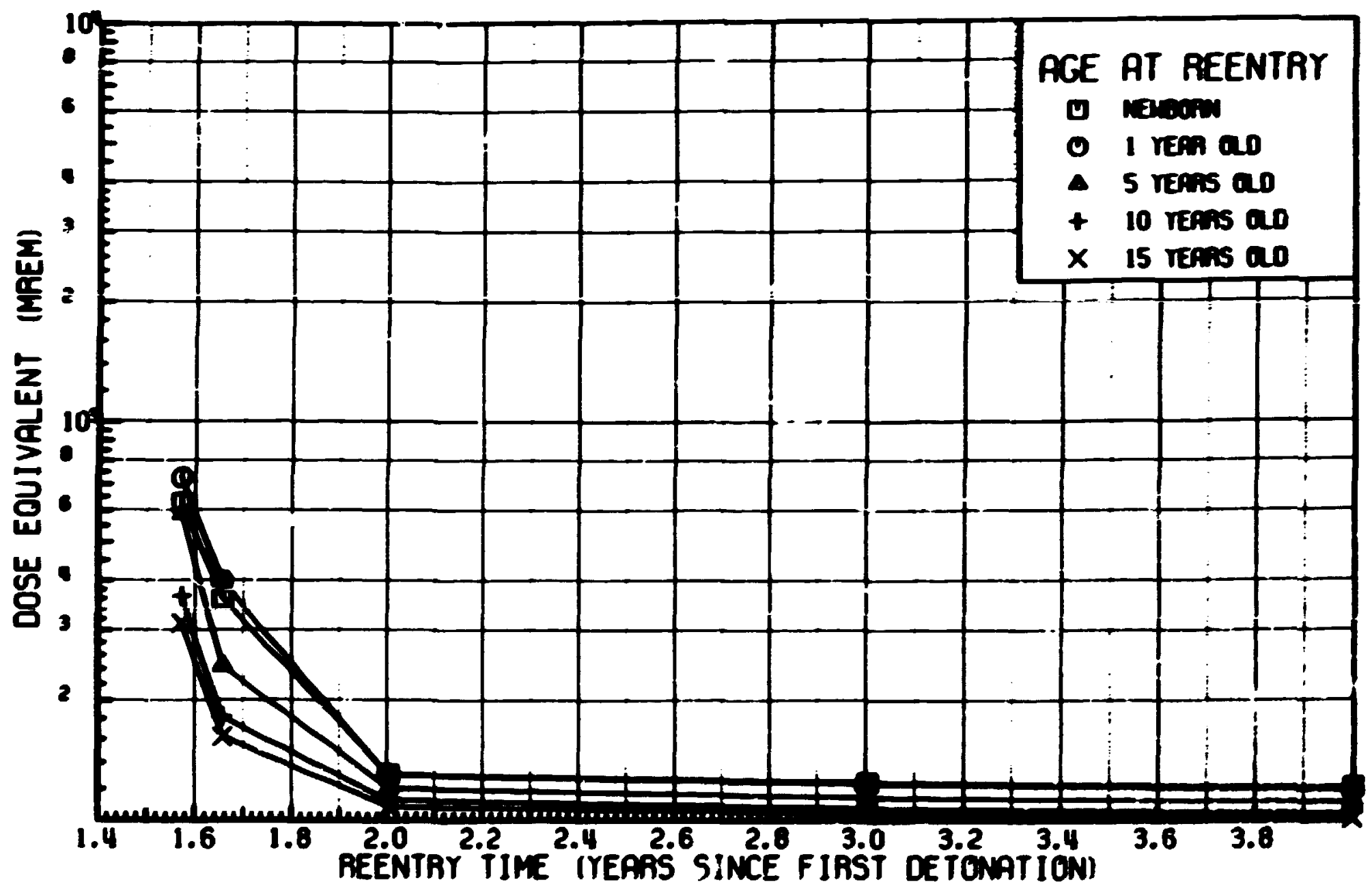

F1g. 8. Dose Comitment to Bone as Result of Radionuclide Ingestion (Colonists, Watershed 2, Route 25). 